ESCUELA TÉCNICA SUPERIOR DE INGENIERÍA AGRONÓMICA, ALIMENTARIA Y DE BIOSISTEMAS

\title{
NUTRITIVE EVALUATION OF OLIVE CAKE AND TOMATO POMACE FOR SMALL RUMINANT FEEDING
}

PhD THESIS

CARLOS NAVARRO MARCOS

M. Sc in Animal Production and Health 

DEPARTAMENTO DE PRODUCCIÓN AGRARIA

ESCUELA TÉCNICA SUPERIOR DE INGENIERÍA AGRONÓMICA,

ALIMENTARIA Y DE BIOSISTEMAS

UNIVERSIDAD POLITÉCNICA DE MADRID

\section{NUTRITIVE EVALUATION OF OLIVE CAKE AND TOMATO POMACE FOR SMALL RUMINANT FEEDING}

\section{Carlos Navarro Marcos}

M. Sc in Animal Production and Health

Supervised by María Dolores Carro Travieso (Doctor in Veterinary)

Escuela Técnica Superior de Ingeniería Agronómica, Alimentaria y de Biosistemas

Madrid, 2019 



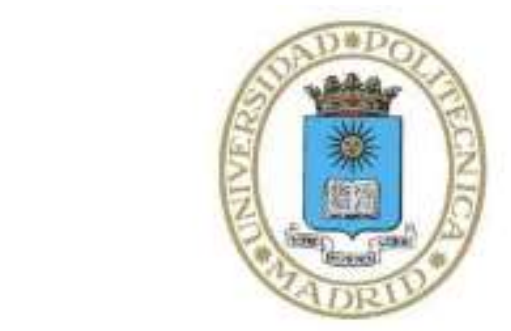

\section{UNIVERSIDAD POLITÉCNICA DE}

MADRID

Tribunal nombrado por el Mgfco. y Excmo. Sr. Rector de la Universidad Politécnica de Madrid, el día. de. de 2019.

\section{Presidente:}

Vocal:

Vocal:

Vocal:

Secretario:

Suplente:

Suplente:

Realizado el acto de defensa y lectura de la Tesis el día de. de 2019, en la E.T.S.I. Agronómica, Alimentaria y de Biosistemas. 



\section{ACKNOWLEDGEMENTS}

I would like to thank everyone who has helped me with this Thesis. To the Animal

Production Research Group of the Polythecnic University of Madrid, and especially to my supervisor, Dolores. To the Estación Experimental del Zaidin, to Ana, Júlia and Edu for that experience down the south.

And to my loved ones.

This research was conducted within the Project AGL2016-75322-C2-1-R funded by the Spanish State Research Agency (AEI) and the European Regional Development Fund. 



\section{INDEX}

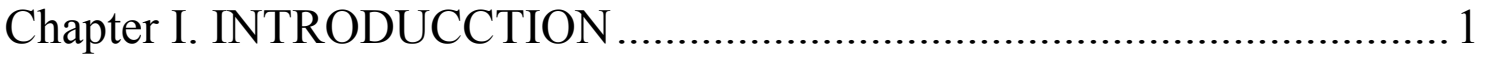

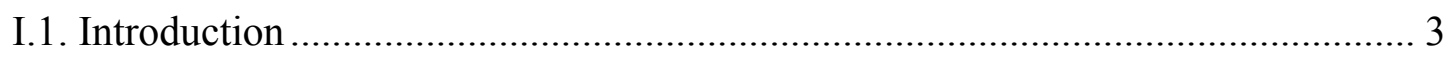

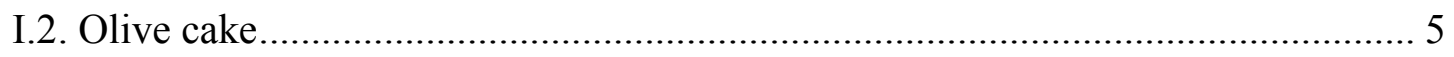

I.2.1. Olive cake production .......................................................................... 5

I.2.2. Chemical composition and characteristics of olive cake ................................ 9

I.2.3. Nutritive value of olive cake .................................................................... 10

I.2.4. Effects of feeding olive cake to meat-producing ruminants .......................... 12

I.2.5. Effects of feeding olive cake to dairy ruminants......................................... 13

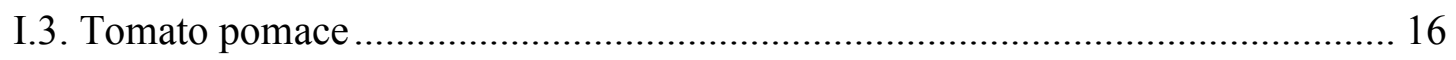

I.3.1. Tomato pomace production................................................................... 16

I.3.2. Chemical composition and characteristics of tomato pomace ....................... 18

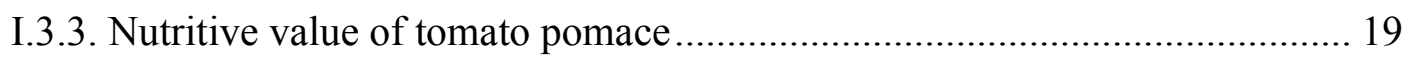

I.3.5. Effects of feeding tomato pomace to dairy ruminants ................................. 22

I.4. Other by-products: citrus pulp and dried distillers grains with solubles.............. 24

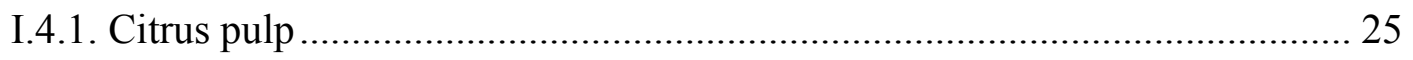

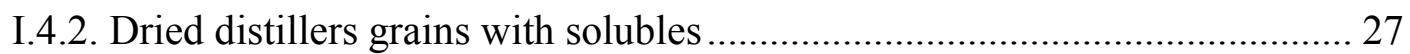

I.5. Nutritional significance of acid detergent insoluble nitrogen fraction of feeds... 29

I.6. Objectives and working hypothesis .............................................................. 32

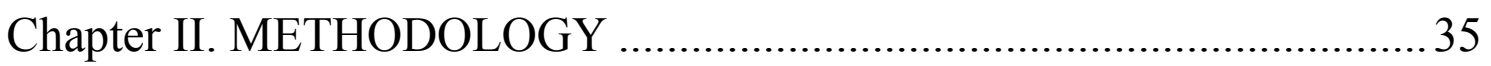

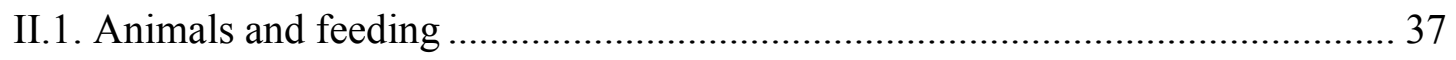

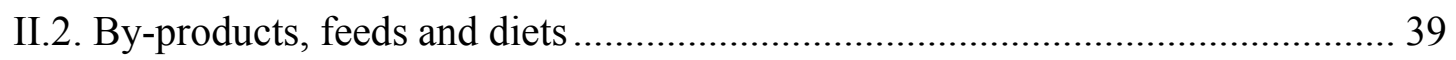

II.3. In vitro incubations: measurement of gas production kinetics ............................. 43

II.4. In vitro incubations: measurement of fermentation parameters .......................... 44

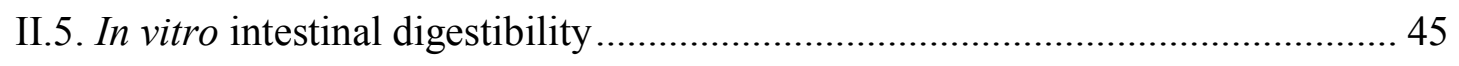

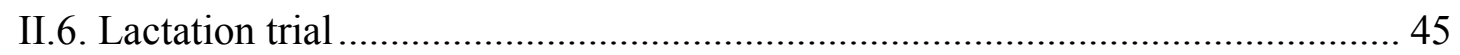

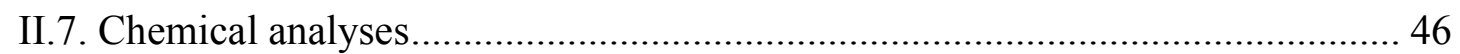

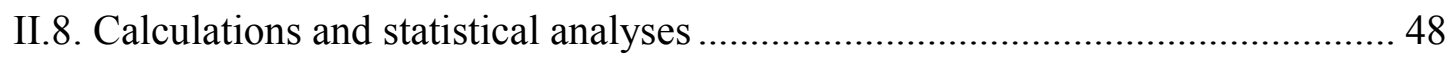

Chapter III. INFLUENCE OF STORAGE TIME AND PROCESSING ON CHEMICAL COMPOSITION AND IN VITRO RUMINAL FERMENTATION OF OLIVE CAKE .....................................................53

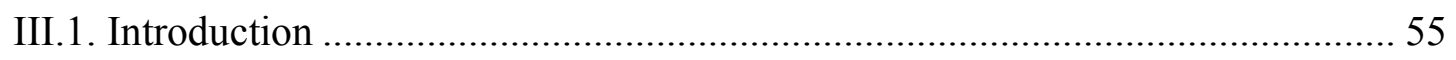

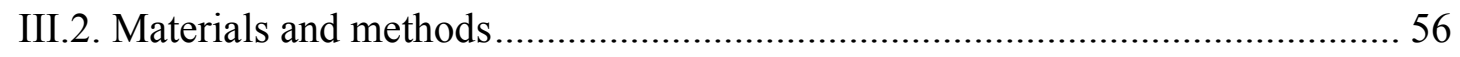




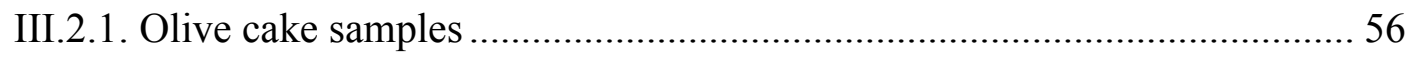

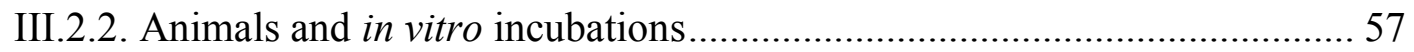

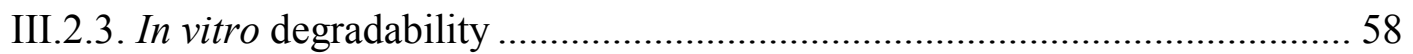

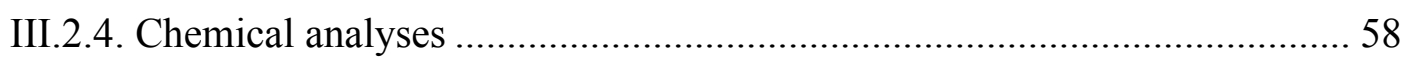

III.2.5. Calculations and statistical analyses................................................... 59

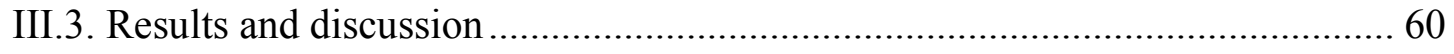

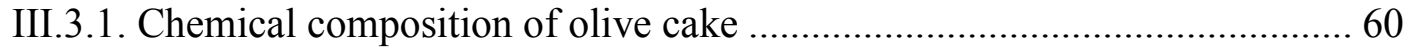

III.3.2. Effects of storage time on in vitro fermentation of olive cake .................. 64

III.3.3. Effects of processing treatment on in vitro fermentation of olive cake...... 70

Chapter IV. VARIABILITY IN THE CHEMICAL COMPOSITION AND IN VITRO RUMINAL FERMENTATION OF OLIVE CAKE BY-

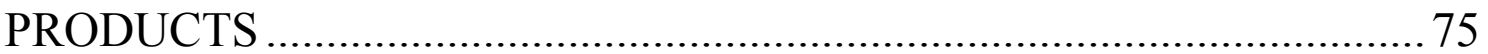

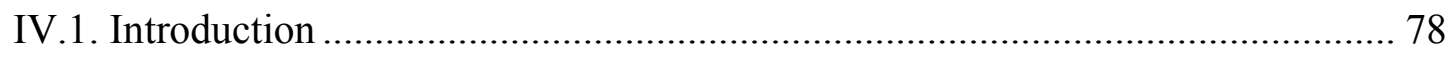

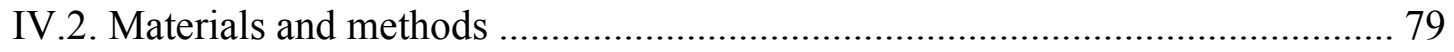

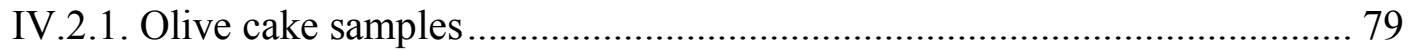

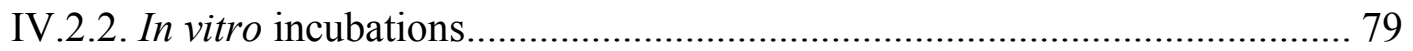

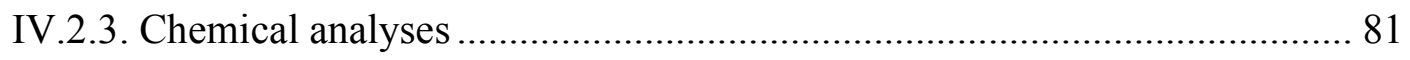

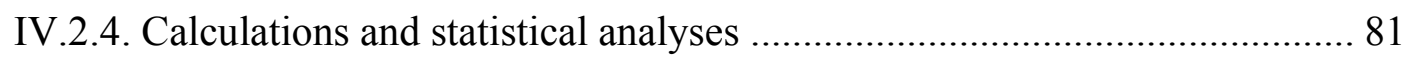

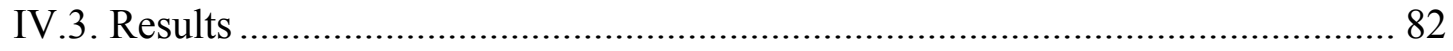

IV.3.1. Influence of olive cake processing type on chemical composition and in

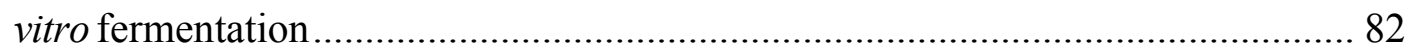

IV.3.2. Estimation of fermentation parameters ................................................ 83

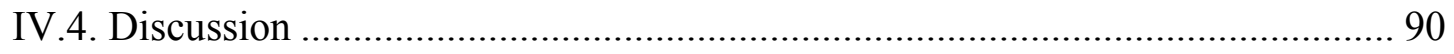

IV.4.1. Influence of olive cake processing on chemical composition and in vitro

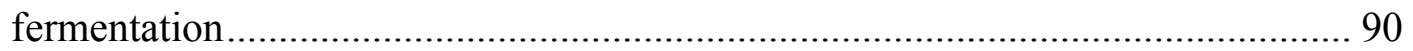

IV.4.1. Estimation of fermentation parameters ............................................ 92

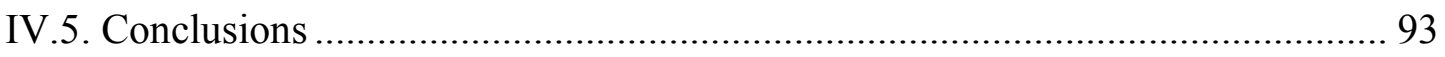

Chapter V. NUTRITIVE VALUE OF TOMATO POMACE FOR RUMINANTS AND ITS INFLUENCE ON IN VITRO METHANE

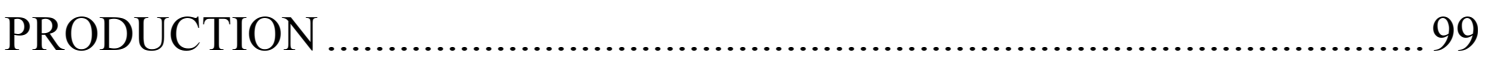

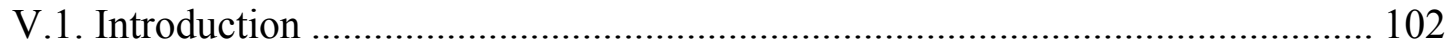

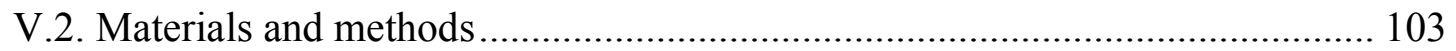

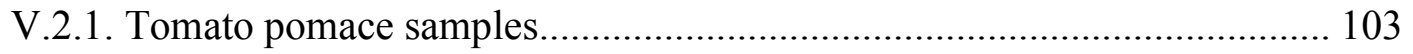

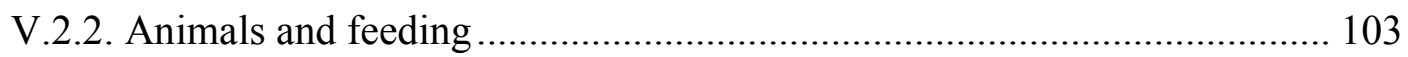


V.2.3. Experimental design 103

V.2.3.1. Experiment 1: in vitro fermentation of TP samples. 104

V.2.3.2. Experiment 1: in vitro intestinal digestibility of tomato pomace samples 105

V.2.3.3. Experiment 2: in vitro fermentation of diets containing tomato pomace 105

V.2.4. Chemical analyses 107

V.2.5. Calculations and statistical analyses ..................................................... 108

V.3. Results 109

V.3.1. Chemical composition of tomato pomace samples, in vitro fermentation, and intestinal digestibility of crude protein 109

V.3.2. In vitro fermentation of diets containing tomato pomace. 110

V.4. Discussion. 116

V.4.1. Chemical composition, in vitro fermentation, and in vitro intestinal digestibility of tomato pomace samples 116

V.4.2. In vitro fermentation of diets containing tomato pomace. 118

V.5. Conclusions 119

Chapter VI. THE ACID DETERGENT INSOLUBLE NITROGEN (ADIN) ANALYSIS OVERESTIMATES THE AMOUNT OF N ASSOCIATED

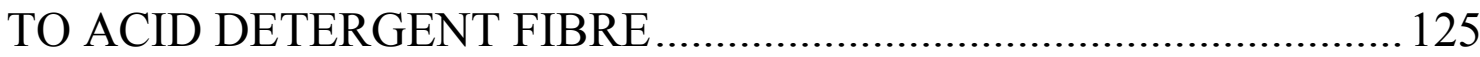

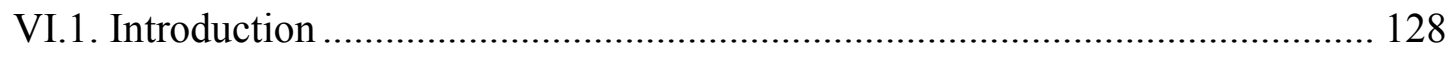

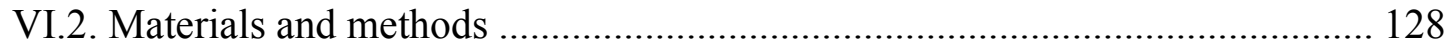

VI.2.1. Samples and experimental procedures ................................................ 128

VI.2.2 Calculations and statistical analyses ................................................... 130

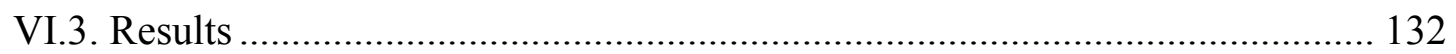

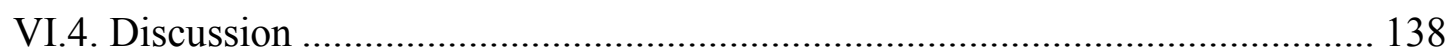

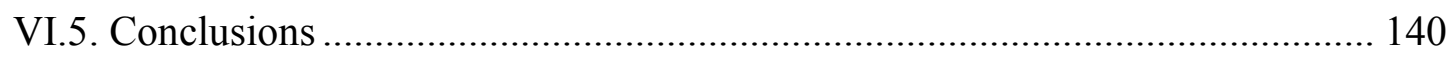

Chapter VII. GENERAL DISCUSSION ................................................. 143

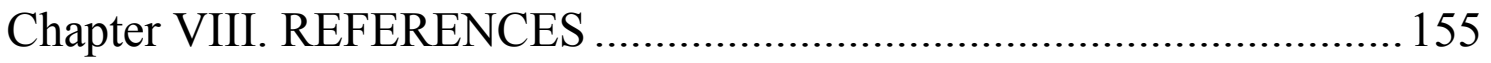

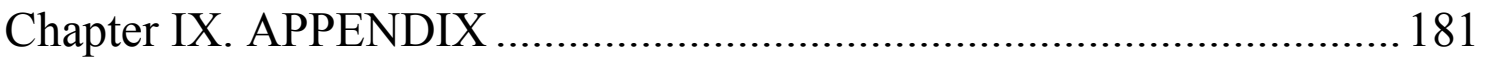

IX.1. Influence of particle size of crude olive cake on in vitro ruminal fermentation

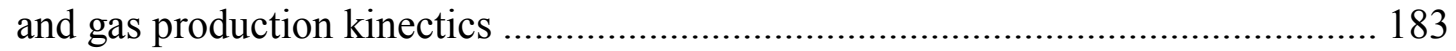

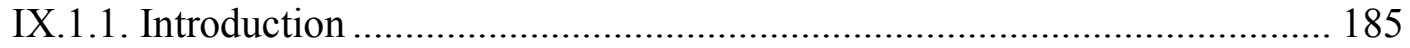

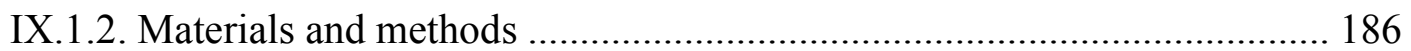

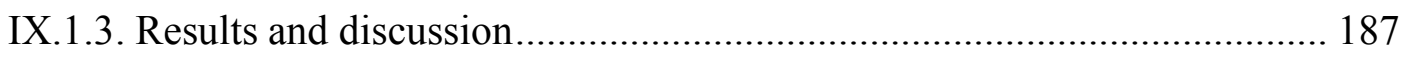


IX.1.4. Conclusions

IX.2. Effects of agro-industrial by-products supplementation on dairy goats milk characteristics, nutrients utilization, ruminal fermentation and methane production 193

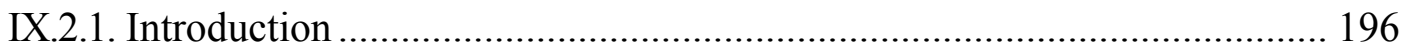

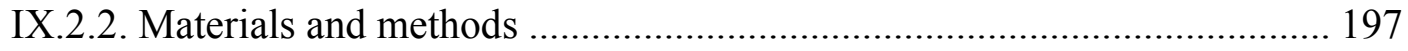

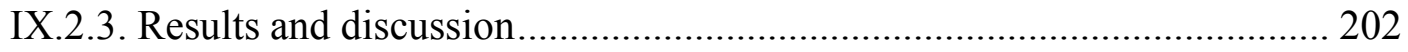

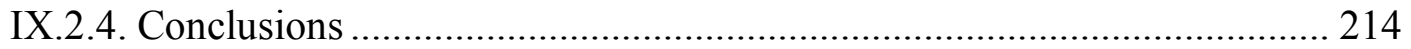

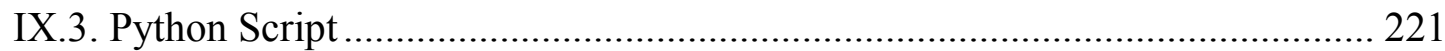




\section{ABBREVIATIONS}

Acid detergent fibre

ADF

Acid detergent insoluble nitrogen

ADIN

Acid detergent lignin

ADL

Average gas production rate

AGPR

Body weight

BW

Cetyltrimethylammonium bromide

CTAB

Coefficient of variation

$\mathrm{CV}$

Conjugated linoleic acid

CLA

Control diet

$\mathrm{CON}$

Crude Olive Cake

$\mathrm{COC}$

Crude protein

$\mathrm{CP}$

Cyclone Olive Cake

CYOC

Dried citrus pulp

DCP

Dried distillers grains with solubles

DDGS

Dry matter

DM

Dry matter effective degradability

DMED

Ether extract

EE

European Union

EU

Exhausted Olive Cake

EOC

Experimental diet

BYP

FA methyl esters

FAME

Fatty acids

FA

Fermented organic matter

FOM

Intestinal digestibility of protein

IDCP

Monounsaturated FA

MUFA

Neutral detergent fibre

NDF

Neutral detergent insoluble $\mathrm{N}$

NDIN

Nitrogen

$\mathrm{N}$

Olive Cake

OC

Organic Matter

$\mathrm{OM}$

Polyethylene glycol

PEG

Polyunsaturated FA

PUFA

Potential in vitro DM degradability

DMD120

Potential gas production

PGP

Purine derivative

PD

Saturated fatty acids

SFA

Sunflower

SF

In vitro DM digestibility

DMD 
In vitro NDF digestibility

NDFD

Tomato pomace

TP

Total solids

TS

Total soluble polyphenols

TSP

Volatile fatty acids

VFA 


\section{FIGURE INDEX}

Figure 1. Phases of olive oil extraction and by-product production (Habeed et al., 2017).

Figure 2. Prediction of AGPR with a neural network including olive cake (OC) data. 151

Figure 3. Prediction of AGPR with a neural network including olive cake (OC) and tomato pomace (TP) data

Figure 4. In vitro cumulative gas production of COC samples with different particle size and two forages. 189 



\section{TABLE INDEX}

Table 1. Ingredient and chemical composition of the experimental concentrates fed to dairy goats and potential use as human food of concentrate ingredients. 38

Table 2. Samples of olive cake (OC) used in this Thesis representative of those available in Spain for animal feeding were obtained at nine different extraction plants.

Table 3. Ingredients and chemical composition of experimental diets containing increased amounts of tomato pomace (TP).

Table 4. Chemical composition and in vitro dry matter (DMD) and neutral detergent fibre (NDFD) degradability of olive cake samples obtained after different storage time in ponds and processing.

Table 5. Correlation matrix (Pearson coefficient and P-values in brackets; $n=21$ ) of chemical composition of OC samples with gas production parameters, in vitro degradability and fermentation parameters in $24 \mathrm{hr}$ in vitro incubations (only P-values $\leq$ 0.10 values are shown).

Table 6. Effect of processing (PR) and storage time in pond (Time) of olive cake (OC) samples on gas production kinetics parameters.

Table 7. Effect of processing (PR) and storage time in pond (Time) of olive cake (OC) samples on gas production kinetics parameters.

Table 8. Effect of processing (PR) and storage time in the pond (Time) of olive cake (OC) samples on fermentation parameters in $24 \mathrm{hr}$ in vitro ruminal fermentation.

Table 9. Effect of processing (PR) and storage time in the pond (Time) of olive cake (OC) samples on fermentation parameters in 24-hr in vitro ruminal fermentation. 69

Table 10. Chemical composition ( $\mathrm{g} / \mathrm{kg}$ dry matter unless stated otherwise) of olive cake (OC) samples $(n=42)$.

Table 11. Influence of olive cake (OC) processing on chemical composition ( $\mathrm{g} / \mathrm{kg}$ dry matter unless stated otherwise).

Table 12. Influence of olive cake (OC) processing on gas production parameters, dry matter effective degradability (DMED) and fermentation parameters in a $24 \mathrm{~h}$ in vitro 
fermentation of OC samples.

Table 13. Correlation matrix (Pearson coefficient and $p$ values in brackets; $n=42$ ) of the chemical composition of olive cake (OC) samples and storage time with the average gas production rate (AGPR) and fermented organic matter (FOM) of OC samples measured in $24 \mathrm{~h}$ in vitro incubations (only $\mathrm{P}<0.05$ values are shown) ${ }^{1}$. 88

Table 14. Models for predicting the average gas production rate (AGPR; $\mathrm{mL} / \mathrm{h}$ ) and fermented organic matter (FOM; g/kg OM) after $24 \mathrm{~h}$ in vitro incubation of olive cake (OC) samples using OC type (crude (COC), exhausted (EOC) and cyclone (CYOC)) as the fixed effect and either chemical fractions or storage time as covariates $(n=42)^{1} \ldots \ldots 89$

Table 15. Ingredients and chemical composition of control and experimental diets containing increased amounts of tomato pomace (TP) used in Experiment 2. 106

Table 16. Chemical composition ( $\mathrm{g} / \mathrm{kg}$ dry matter (DM) unless stated otherwise) of tomato pomace samples taken from two processing plants at weekly intervals during the tomato harvesting campaign.

Table 17. Gas production kinetics and fermentation parameters of tomato pomace samples taken from two processing plants at weekly intervals during the tomato harvesting campaign and samples.

Table 18. In situ rumen degradability of dry matter (DM) and crude protein (CP) after $16 \mathrm{~h}$ of incubation, in vitro intestinal digestibility of $\mathrm{CP}$ (IDCP), and total CP digestibility of tomato pomace samples taken from two processing plants at weekly intervals during the tomato harvesting campaign.

Table 19. Correlation matrix (Pearson coefficient and $p$-values in brackets; $n=12$ ) of chemical composition of tomato pomace samples with gas production parameters, dry matter effective degradability (DMED), fermentation parameters measured in 24-h in vitro incubations, in situ rumen degradability of dry matter (DM) and crude protein (CP) after $16 \mathrm{~h}$ of incubation, and in vitro intestinal digestibility of $\mathrm{CP}$ (only $\mathrm{P}<0.10$ values are shown) ${ }^{1}$

Table 20. Gas production parameters and fermentation parameters after 8 and $24 \mathrm{~h}$ of in vitro fermentation of diets containing increased amounts of tomato pomace incubated in batch cultures of mixed rumen microorganisms ${ }^{1}$. 115

Table 21. Chemical composition ( $\mathrm{g} / \mathrm{kg}$ DM unless otherwise stated) of corn and 
sunflower ${ }^{15} \mathrm{~N}$-enriched samples by using either ${ }^{15} \mathrm{NH}_{4} \mathrm{NO}_{3} \quad\left({ }^{15} \mathrm{NAM}\right)$ or $\left.\mathrm{NH}_{4}{ }^{15} \mathrm{NO}_{3}{ }^{15} \mathrm{NIT}\right)$ as fertilizers $(n=3)$.

Table 22. ${ }^{15} \mathrm{~N}$ abundance (atom\%) in total nitrogen $(\mathrm{N})$, neutral detergent insoluble $\mathrm{N}$ (NDIN) and acid detergent insoluble $\mathrm{N}$ (ADIN) of corn and sunflower samples labelled with either ${ }^{15} \mathrm{NH}_{4} \mathrm{NO}_{3}\left({ }^{15} \mathrm{NAM}\right)$ or $\mathrm{NH}_{4}{ }^{15} \mathrm{NO}_{3}\left({ }^{15} \mathrm{NIT}\right)$ applied as fertilizers.

Table 23. N contamination of acid detergent insoluble nitrogen (ADIN; g/g) in corn and sunflower samples labelled with either ${ }^{15} \mathrm{NH}_{4} \mathrm{NO}_{3}\left({ }^{15} \mathrm{NAM}\right)$ or $\mathrm{NH}_{4}{ }^{15} \mathrm{NO}_{3}$ ( $\left.{ }^{15} \mathrm{NIT}\right)$ applied as fertilizers ${ }^{1}$.

Table 24. Correlation matrix (values of Pearson coefficient and $\mathrm{P}$ values in brackets) of nitrogen $(\mathrm{N})$ contamination of acid detergent insoluble $\mathrm{N}$ (ADIN) with fibre fractions in corn and sunflower samples ${ }^{1}$. 136

Table 25. Values of acid detergent insoluble N (ADIN) content, ${ }^{15} \mathrm{~N}$-abundance and $\mathrm{N}$ contamination of ADIN, and ADIN corrected for N-contamination from cetyltrimethylammonium bromide (true ADIN) in samples from aerial biomass of corn and sunflower (SF1 and SF2) obtained by using sequential and non-sequential methods of ADFom analysis.

Table 26. Chemical composition ( $\mathrm{g} / \mathrm{Kg}$ dry matter) and in vitro dry matter digestibility (IVDMD) of crude olive cake (COC) samples with different particle size and two forages. 188

Table 27. Gas production parameters of crude olive cake (COC) samples with different particle size and two forages $(n=4)^{1}$.

Table 28. In vitro fermentation parameters after $24 \mathrm{~h}$ incubation of crude olive cake (COC) samples with different particle size and two forages with buffered ruminal fluid from sheep $(n=4)^{1}$

Table 29. Ingredient and chemical composition of experimental concentrates and potential use as human food of concentrate ingredients.

Table 30. Average values of feed and water intake and apparent digestibility of nutrients in dairy goats fed the experimental diets. 204

Table 31. Average BW and BW change over the trial and values of $\mathrm{N}$ and energy utilization in dairy goats fed the experimental diets. 207 
Table 32. Average values of milk yield and composition and feed efficiency in dairy goats fed the experimental diets. 208

Table 33. Average values of fatty acids (FA) composition ( $\mathrm{g} / 100 \mathrm{~g}$ of identified FA) in milk fat from dairy goats fed the experimental diets. 210 Table 34. Average values of ruminal fermentation parameters, methane emissions, daily urinary excretion of creatinine and purine derivatives and estimated microbial $\mathrm{N}$ flow in dairy goats fed the experimental diets. 213 


\section{SUMMARY}

The use of agroindustrial by-products in animal feeding requires precise information on their nutritional value. However, agroindustrial by-products are heterogeneous and as consequence, values for chemical composition and nutritive parameters are highly variable, and the information related is scarce. For that reason, the objective of this Doctoral Thesis is to evaluate the nutritive value of two by-products that are produced in huge amounts in Spain: olive cake (OC) and tomato pomace (TP). In order to achieve this objective, six Experiments (five in vitro and one in vivo) were conducted.

The objective of Experiment 1 (Paper 1) was to analyse the influence of storage time and further processing: crude OC (COC), exhausted OC (subjected to a second oil extraction; EOC) and cyclone OC (obtained from a cyclone separator; CYOC) on nutritive value of OC samples. Twelve samples (six COC and six EOC) were obtained monthly from the same pond from 1 to 6 storage months, and nine samples (three COC, three EOC and three CYOC) were obtained monthly from a different pond from 6 to 9 months storage. Chemical composition was analysed, and OC samples were fermented in vitro with sheep rumen fluid. Increasing storage time up to 6 months decreased sugars and total soluble polyphenols (TSP) content but increased fibre content in OC. Dry matter effective degradability (DMED) decreased linearly $(\mathrm{P}<0.001)$ by 35.9 and $45.5 \%$ as storage time augmented from 1 to 6 months for COC and EOC, respectively. COC had lower DMED values than EOC (averaged values 0.255 and $0.294 \mathrm{~g} / \mathrm{g}$, respectively). Both potential gas production (PGP) and average gas production rate (AGPR) were lower $(\mathrm{P} \leq 0.018)$ in COC compared with EOC, which was attributed to the high ether extract (EE) content of COC ( $\geq 86 \mathrm{~g} / \mathrm{kg}$ dry matter (DM)). For samples stored longer than 6 months, CYOC had greater $(\mathrm{P}<0.05)$ DMED than COC and EOC (averaged values $0.207,0.164$ and $0.164 \mathrm{~g} / \mathrm{g}$, respectively). The results indicate that ruminal degradability of $\mathrm{OC}$ is reduced with advancing storage time, but only subtle changes were observed during the first two months. CYOC showed greater degradability than COC and EOC, but differences between COC and EOC became negligible after five storage months.

The objective of Experiment 2 (Paper 2) was to determine the variability in the chemical composition and in vitro ruminal fermentation of OC by-products. Forty-two 
OC samples with different storage times (1-14 months) and processing (25 COC, 9 EOC and 9 CYOC) were fermented in vitro with sheep ruminal fluid. EOC samples had a lower EE content than COC and CYOC (15.9, 110 and $157 \mathrm{~g} / \mathrm{kg} \mathrm{DM}$, respectively), but greater neutral detergent fibre (NDF) $(645,570$ and $441 \mathrm{~g} / \mathrm{kg} \mathrm{DM})$ and acid detergent insoluble nitrogen (ADIN) $(9.76,8.10$ and $8.05 \mathrm{~g} / \mathrm{kg} \mathrm{DM})$ content. EOC had the greatest $(\mathrm{P}<0.05)$ AGPR, whereas the greatest fermented organic matter $(\mathrm{FOM})$ was obtained for EOC and CYOC. The best single predictor of the AGPR was total sugars content $\left(\mathrm{R}^{2}=0.898\right)$, whereas NDF was the best one for FOM $\left(\mathrm{R}^{2}=0.767 ; \mathrm{P}<\right.$ $0.001)$. Statistical models using storage time as a predictor variable had lower accuracy and $\mathrm{R}^{2}$ values than those from the chemical composition. In summary, the nutritive value of OC was highly dependent on its processing, but its EE content did not negatively affect ruminal fermentation parameters, which could be estimated from either carbohydrate composition or storage time.

The aim of this Experiment 3 (Paper 5; Appendix) was to estimate in vitro the nutritive value of four samples of COC with different particle size obtained during the drying process from the same trommel at different stages of the screening procedure. Particles size was greater than $3 \mathrm{~mm}$ (COC3), $2 \mathrm{~mm}$ (COC2) and $1 \mathrm{~mm}$ (COC1) or smaller than $1 \mathrm{~mm}(\mathrm{COC} 0)$. Alfalfa hay and barley straw were included in the study for comparative purposes. Chemical composition was analysed in all samples. Gas production kinetics was determined in $120 \mathrm{~h}$ in vitro incubations with sheep rumen fluid as inoculum, and fermentation parameters and in vitro dry matter digestibility (DMD) were analysed after $24 \mathrm{~h}$ of incubation. COC3 and COC0 samples had lower contents of NDF (415 and $391 \mathrm{~g} / \mathrm{kg} \mathrm{DM})$, but greater crude protein (CP) (96.6 and $114 \mathrm{~g} / \mathrm{kg} \mathrm{DM})$ and EE (220 and $242 \mathrm{~g} / \mathrm{kg} \mathrm{DM})$ contents, than COC2 and COC1 (627 and 624; 42.4 and 48.7; 102 and $124 \mathrm{~g} / \mathrm{kg} \mathrm{DM}$, respectively). DMD of COC samples ranged from 39.4 to $58.7 \%$, and was lower than that for alfalfa hay (67.5\%) for all samples, but greater than that for barley straw (42.4\%) for COC0 and COC3 samples. COC3 and COC0 samples had greater $(\mathrm{P}<0.05)$ PGP $(103$ and $66.2 \mathrm{ml} / \mathrm{g}$ DM, respectively) and total volatile fatty acids (VFA) production (608 and $600 \mu \mathrm{mol}$, respectively) than COC2 and COC1, but values were lower than those for alfalfa hay $(202 \mathrm{ml} / \mathrm{g} \mathrm{DM}$ and $1023 \mu \mathrm{mol}$, respectively) and barley straw $(198 \mathrm{ml} / \mathrm{g} \mathrm{DM}$ and $733 \mu \mathrm{mol})$. The results indicate that decreasing particle size to $<1 \mathrm{~mm}$ increased the fermentation potential of COC, but its nutritive value was still slightly lower than that of barley straw. The similar quality 
observed for COC3 and COC0 samples was attributed to the high sugar content of COC3 samples.

The objective of Experiment 4 (Paper 3) was to determine the variability in nutritive value for ruminants of TP samples and analyze its effect on in vitro fermentation when it was included in a high-concentrate diet. Twelve TP samples were obtained from two processing plants at weekly intervals and analysed for chemical composition, in vitro rumen fermentation, and intestinal digestibility. The chemical composition of TP did not differ between processing plants and only slight variations were observed among sampling times. Tomato pomace had a low DM content $(<300$ $\mathrm{g} / \mathrm{kg}$ ), a high content of NDF, CP and EE $(572,160$, and $82.7 \mathrm{~g} / \mathrm{kg}$ DM on average, respectively), and was rapidly fermented in the rumen. Protein degradability at $16 \mathrm{~h}$ in situ incubation was $510 \mathrm{~g} / \mathrm{kg}$ and in vitro intestinal digestibility of CP (IDCP) was low $(430-475 \mathrm{~g} / \mathrm{kg})$. Replacing soybean meal and barley straw by dried TP increased the in vitro fermentation rate and the production of VFA and reduced $\mathrm{NH}_{3}-\mathrm{N}$ concentrations without affecting methane. In summary, TP samples showed little variability in nutritive value over sampling time and TP of up to $180 \mathrm{~g} / \mathrm{kg}$ could be included in highconcentrate diets without negatively affecting rumen fermentation.

The objective of Experiment 5 (Paper 6; Appendix) was to determine the effect of including agroindustrial by-products, such as dried distillers grains with solubles (DDGS), dried citrus pulp (DCP) and EOC in diets for dairy goats on nutrient digestibility, ruminal fermentation, methane production, urinary excretion of purine derivatives (PD) and milk yield and composition. Twelve Murciano-Granadina goats were used in a cross-over design trial with two periods. In each period, six goats received daily a control diet composed of $1 \mathrm{~kg}$ of alfalfa hay and $1 \mathrm{~kg}$ of high-cereal concentrate and other six goats received a diet (BYP) composed of $1 \mathrm{~kg}$ of alfalfa hay and $1 \mathrm{~kg}$ of a concentrate including corn DDGS, DCP and EOC in proportions of 180, 180 and $80 \mathrm{~g} / \mathrm{kg}$ concentrate (as fed basis), respectively. Diet had no effect on total DM intake, but intake of alfalfa hay, $\mathrm{CP}$ and $\mathrm{EE}$ was greater $(\mathrm{P} \leq 0.042)$ for the BYP than for control group. There were no differences between diets in nutrients apparent digestibility, with the exception of fat which was greater $(\mathrm{P}=0.002)$ for $\mathrm{BYP}$ compared with control diet. Although fecal nitrogen $(\mathrm{N})$ tended to be greater $(\mathrm{P}=$ 0.063) for BYP-diet, there were no differences in $\mathrm{N}$ utilization. Compared to control, milk yield tended to be greater $(\mathrm{P}=0.056)$ and daily production of milk $\mathrm{CP}$, fat, whey 
protein and total solids (TS), as well as milk gross energy, were greater $(\mathrm{P} \leq 0.031)$ for BYP diet. Diet BYP promoted a healthier fatty acids (FA) profile in milk, as the concentration of $\mathrm{C} 12: 0, \mathrm{C} 14: 0$ and $\mathrm{C} 16: 0 \mathrm{FA}$ was or tended to be lower $(\mathrm{P} \leq 0.080)$ and that of polyunsaturated FA (PUFA) was greater $(\mathrm{P}=0.001)$ in the milk of BYPfed goats compared with those fed the control diet. Diet had no effect on ruminal parameters ( $\mathrm{pH}, \mathrm{VFA}$ and $\mathrm{NH}_{3}-\mathrm{N}$ concentrations) and methane emissions, but urinary excretion of total PD tended to be lower $(\mathrm{P}=0.070)$ in BYP-fed goats than in those fed the control diet. A mixture of corn DDGS (180 g), DCP (180 g) and EOC (80 g) could replace $44 \%$ of cereal grains and protein feeds in the concentrate for dairy goats without compromising nutrient utilization, ruminal fermentation or milk yield, and led to a healthier FA profile in milk.

The objective of Experiment 6 (Paper 4) was to verify lower ${ }^{15} \mathrm{~N}$ abundances of ADIN than of total $\mathrm{N}$ and neutral detergent insoluble $\mathrm{N}$ (NDIN) in different feeds, and to assess the magnitude of ADIN contamination. Samples from one corn crop (aerial biomass, grain and root) and two sunflower (SF) crops (aerial biomass and seeds) were analysed for ${ }^{15} \mathrm{~N}$ abundance and content of total N, NDIN and ADIN. Samples had been ${ }^{15} \mathrm{~N}$-labelled by fertilizing with either ${ }^{15} \mathrm{NH}_{4} \mathrm{NO}_{3}$ or $\mathrm{NH}_{4}{ }^{15} \mathrm{NO}_{3}$, and there were three replicates per type of sample. The ${ }^{15} \mathrm{~N}$-abundance of total $\mathrm{N}$ and NDIN was similar $(\mathrm{P}>$ $0.05)$ for all samples, whereas that of ADIN was lower $(\mathrm{P}<0.001$ to 0.037$)$ than values for total N and NDIN for all samples, excepting for SF seeds from one crop. Estimates of N-contamination of ADIN from cetyltrimethylammonium bromide (CTAB) were not affected by the fertilizer used to label $\mathrm{N}(\mathrm{P} \geq 0.207)$, and values $(\mathrm{g} / \mathrm{g})$ ranged from 0.129 for corn grains to 0.447 for corn aerial biomass. N-contamination of ADIN was positively correlated with NDF, acid detergent fibre (ADF), hemicelluloses and cellulose content ( $\mathrm{P}<0.001 ; \mathrm{r}=0.770$ to $0.905 ; n=18$ and 22 for corn and SF, respectively), and negatively ( $\mathrm{P}<0.001$ to 0.048 ) with ADIN content (expressed as proportion of ADF). The negative correlations $(\mathrm{P}<0.001)$ between $\mathrm{N}$-contamination of ADIN and acid detergent lignin (ADL)/ADF ratio observed for all samples would indicate that $\mathrm{N}$-contamination of $\mathrm{ADIN}$ was reduced by cell wall lignification. In conclusion, the results showed that the use of CTAB in the ADF analysis resulted in increased ADIN values, and therefore overestimated the amount of $\mathrm{N}$ associated to $\mathrm{ADF}$, questioning the use of ADIN as a parameter indicative of $\mathrm{N}$ availability. 


\section{RESUMEN}

El uso de subproductos agroindustriales en alimentación animal requiere conocer su valor nutritivo. Sin embargo, estos subproductos son heterogéneos y como consecuencia, su composición química y valor nutritivos son muy variables, además de que la información al respecto es escasa. Por esta razón, el objetivo de esta Tesis Doctoral fue evaluar dos subproductos producidos en grandes cantidades en España: orujo de aceituna (OC) y pulpa de tomate (TP). Para lograr este objetivo, se llevaron a cabo seis Experimentos (cinco in vitro y uno in vivo).

El objetivo del primer experimento (Artículo 1) fue analizar el efecto del tiempo de almacenaje y su posterior procesado: OC crudo (COC), OC extractado (EOC), OC ciclón (CYOC), en el valor nutritivo. Se utilizaron doce muestras (seis COC y seis EOC) obtenidas a intervalos de un mes de la misma balsa con un tiempo de almacenamiento de 1 a 6 meses, y nueve muestras (tres COC, tres EOC y tres CYOC) obtenidas a intervalos de un mes de una balsa diferente con un tiempo de almacenamiento de 6 a 9 meses. Se analizó la composición química y se fermentaron las muestras in vitro con líquido ruminal de oveja. El aumento del tiempo de almacenmiento hasta los 6 meses redujo el contenido en azúcares y polifenoles totales solubles (TSP), pero aumentó el contenido en fibra. La degradabilidad efectiva de la materia seca (DMED) se redujo de forma lineal $(\mathrm{P}<0,001)$ en un 35,9 y $45,5 \%$ al aumentar el tiempo de almacenamiento de 1 a 6 meses en las muestras de COC y EOC, respectivamente. Las muestras de COC tuvieron una menor degradabilidad efectiva de la materia seca (DMED) que las muestras de EOC (valores medios de 0,255 y 0,294 $\mathrm{g} / \mathrm{g}$, respectivamente). Tanto la producción potencial de gas (PGP) como el ritmo medio de producción de gas $(\mathrm{AGPR})$ fueron menores $(\mathrm{P} \leq 0,018)$ en las muestras de COC que en las muestras EOC, y esto se debió al mayor contenido en extracto etéreo (EE) en las muestras de COC ( $\geq 86 \mathrm{~g} / \mathrm{kg}$ materia seca $(\mathrm{DM})$ ). En las muestras con un tiempo de almacenamiento superior a 6 meses, las muestras CYOC tuvieron mayores $(\mathrm{P}<0,05)$ valores de DMED que las muestras COC y EOC (valores medios 0,207, 0,164 y 0,164 $\mathrm{g} / \mathrm{g}$, respectivamente). Los resultados indican que la degradabilidad ruminal del OC se reduce al aumentar el tiempo de almacenamiento, pero únicamente se observan pequeños cambios durante los dos primeros meses. El CYOC tuvo mayor degradabilidad ruminal que el COC y EOC, pero las diferencias entre estos dos últimos fueron reducidas a partir de los 5 meses se almacenamiento. 
El objetivo del Experimento 2 (Artículo 2) fue estudiar la variabilidad en la composición química y la fermentación ruminal in vitro del OC. Para ello se fermentaron in vitro con líquido ruminal de ovejas 42 muestras de OC con diferentes tiempos de almacenamiento ( 1 a 14 meses) y procesado (25 COC, 9 EOC y 9 CYOC). Las muestras de EOC tuvieron menor contenido en EE que las muestras de COC y CYOC (15,9, 110 y $157 \mathrm{~g} / \mathrm{kg} \mathrm{DM}$, respectivamente), pero mayor contenido en fibra neutro detergente (NDF; 645, 570 y $441 \mathrm{~g} / \mathrm{kg}$ DM) y nitrógeno insoluble en solución ácido detergente (ADIN; 9,76, 8,10 y 8,05 g/kg DM). Las muestras de EOC tuvieron el mayor $(\mathrm{P}<0,05)$ ritmo fraccional de producción de gas (AGPR), mientras que las muestras de EOC y CYOC mostraron la mayor cantidad de materia orgánica fermentada (FOM). La mejor variable para predecir el AGPR fue el contenido en azucares $\left(\mathrm{R}^{2}=\right.$ $0,898)$, mientras que el contenido en NDF fue la mejor variable para predecir la FOM $\left(\mathrm{R}^{2}=0,767 ; \mathrm{P}<0,001\right)$. Los modelos estadísticos que utilizaban el tiempo de almacenamiento como variable predictora tuvieron una menor precisión y menores valores de $\mathrm{R}^{2}$ en comparación con aquellos que utilizaban la composición química. En resumen, el valor nutritivo del OC depende del procesado, pero su contenido en EE no afectó negativamente a los parámetros de la fermentación ruminal, que podrían ser estimados a partir del su contenido en carbohidratos o del tiempo de almacenamiento.

El tercer Experimento (Artículo 5; Apéndice) se llevó a cabo para estimar in vitro el valor nutritivo de cuatro muestras de COC con diferentes tamaños de partícula, que fueron obtenidas durante el proceso de secado en un mismo trommel en diferentes momentos del proceso de tamizado. Los tamaños de partícula fueron: mayor de $3 \mathrm{~mm}$ (COC3), $2 \mathrm{~mm}$ (COC2) y $1 \mathrm{~mm}$ (COC1) o menor de $1 \mathrm{~mm}$ (COC0). En este experimento se incluyeron heno de alfalfa y paja de cebada con fines comparativos. Se analizó la composición química en todas las muestras. Los parámetros de producción de gas se obtuvieron mediante una incubación in vitro de 120 horas de duración empleado líquido ruminal de oveja como inóculo, y los parámetros fermentativos y la digestibilidad in vitro de la materia seca (DMD) se analizaron en una incubación de 24 horas. Las muestras COC3 y COC0 tuvieron menores contenidos de NDF (415 y 391 g/kg DM), pero mayor contenido en proteína bruta (CP; 96,6 y 114 g/kg DM) y EE (220 y $242 \mathrm{~g} / \mathrm{kg} \mathrm{DM})$ que las muestras COC2 (627, 42,4 y $102 \mathrm{~g} / \mathrm{kg}$ DM, respectivamente) y COC1 (624, 48,7 y 124 g/kg DM). La DMD de las muestras de COC osciló entre 39,4 y $58,7 \%$ y fue menor que la obtenida para el heno de alfalfa (67,5\%), pero mayor que la 
obtenida para la paja de cebada $(42,4 \%)$ en las muestras COC0 y COC3. Las muestras COC3 y COC0 tuvieron un mayor $(\mathrm{P}<0,05)$ producción potencial de gas $(\mathrm{PGP} ; 103$ y 66,2 $\mathrm{ml} / \mathrm{g} \mathrm{DM}$, respectivamente) y una mayor producción de ácidos grasos volátiles totales (VFA; 608 y $600 \mu \mathrm{mol}$, respectivamente) que las muestras COC2 y COC1, pero los valores fueron menores que los del heno de alfalfa $(202 \mathrm{ml} / \mathrm{g}$ DM y $1023 \mu \mathrm{mol}$, respectivamente) y la paja de cebada $(198 \mathrm{ml} / \mathrm{g}$ DM y $733 \mu \mathrm{mol})$. Los resultados sugieren que reducir el tamaño de partícula a menos de $1 \mathrm{~mm}$ aumenta la fermentabilidad del COC, pero su valor nutritivo sigue siendo ligeramente inferior al de la paja de cebada. La calidad observada en las muestras COC3, similar a la del COC0 se atribuyó a un mayor contenido en azúcares solubles.

El objetivo del Experimento 4 (Artículo 3) fue analizar la variabilidad en el valor nutritivo para los animales rumiantes de la pulpa de tomate (TP) y analizar su efecto en la fermentación ruminal in vitro cuando se incluyó en una dieta con un elevado contenido en concentrado. Se obtuvieron 12 muestras de TP de dos plantas de procesado con intervalos de una semana y se analizó la composición química, la fermentación ruminal in vitro y la digestibilidad intestinal. No se observaron diferencias entre las plantas de procesado en la composición química TP y únicamente se observaron ligeras variaciones entre los diferentes tiempos de muestreo. Las muestras de TP tuvieron un reducido contenido en DM $(<300 \mathrm{~g} / \mathrm{kg})$, un alto contenido en NDF, CP y EE (572, 160 y $82,7 \mathrm{~g} / \mathrm{kg}$ DM de media, respectivamente), y fueron rápidamente fermentadas in vitro. La degradabilidad ruminal de la proteína, obtenida tras una incubación in situ de $16 \mathrm{~h}$, fue $510 \mathrm{~g} / \mathrm{kg}$ y la digestibilidad intestinal in vitro de la CP (IDCP) fue baja, oscilando entre 430 y $475 \mathrm{~g} / \mathrm{kg}$. Reemplazar parcialmente la harina de soja y paja de cebada por TP en una dieta rica en concentrado aumentó el ritmo de fermentación in vitro y la producción de VFA y redujo la concentración de $\mathrm{NH}_{3}-\mathrm{N}$ sin afectar a la producción de metano. En resumen, las muestras de TP mostraron poca variabilidad en su valor nutritivo entre los diferentes tiempos de muestreo y podría incluirse TP hasta $180 \mathrm{~g} / \mathrm{kg}$ en una dieta rica en concentrado sin afectar negativamente a la fermentación ruminal.

El objetivo del Experimento 5 (Artículo 6: Apéndice) fue determinar el efecto de incluir subproductos agroindustriales, en concreto DDGS de maíz (dried distillers grains with solubles), pulpa de cítricos desecada (DCP) y EOC, en un concentrado para cabras lecheras en la digestibilidad de los nutrientes, la fermentación ruminal, la 
producción de metano, la excreción urinaria de derivados púricos $(\mathrm{PD})$ y la producción y composición de la leche. Para ello, se usaron doce cabras de raza Murciano-Granadina en un diseño experimental cruzado con dos periodos. En cada periodo, seis cabras recibieron una dieta control, compuesta de $1 \mathrm{~kg}$ de heno de alfalfa y $1 \mathrm{~kg}$ de concentrado basado en cereales, y las otras seis cabras recibieron una dieta (BYP) compuesta de un $1 \mathrm{~kg}$ de heno de alfalfa y $1 \mathrm{~kg}$ de concentrado con 180,180 y $80 \mathrm{~g} / \mathrm{kg}$ (en materia fresca) de DDGS, DCP y EOC, respectivamente. La dieta no afectó a la ingestión de materia seca de concentrado, pero la ingestión de heno de alfalfa, CP y EE fue mayor $(\mathrm{P} \leq 0,042)$ con la dieta BYP. No se observaron diferencias entre dietas en la digestibilidad aparente de los nutrientes, excepto en la digestibilidad de la grasa que fue mayor $(\mathrm{P}=0,002)$ para la dieta BYP. A pesar de que el nitrógeno $(\mathrm{N})$ fecal tendió a ser mayor $(\mathrm{P}=0,063)$ con la dieta $\mathrm{BYP}$, no hubo diferencias en la utilización del N. En comparación con la dieta control, la producción de leche de las cabras alimentadas con la dieta $\mathrm{BYP}$ tendió a ser mayor $(\mathrm{P}=0,056)$ y la producción diaria de $\mathrm{CP}$, grasa, proteína del suero y sólidos totales (TS) en la leche, así como la energía bruta, fue mayor $(\mathrm{P} \leq 0,031)$ que en las cabras que recibían la dieta control. La dieta BYP favoreció un perfil de ácidos grasos (FA) en la leche potencialmente más saludable, ya que la concentración de C12:0, C14:0 y C16:0 FA fue o tendió a ser menor $(\mathrm{P} \leq 0,080)$ $\mathrm{y}$ el contenido en FA insaturados (PUFA) fue mayor $(\mathrm{P}=0,001)$ que con la dieta control. La dieta no tuvo ningún efecto sobre los parámetros ruminales $(\mathrm{pH}, \mathrm{VFA}$ y $\left.\mathrm{NH}_{3}-\mathrm{N}\right)$ ni en las emisiones de metano, pero la excreción de PD tendió a ser menor $(\mathrm{P}=$ 0,070) en las cabras alimentas con la dieta BYP. Por todo ello, una mezcla de DDGS de maíz (180 g), DCP (180 g) y EOC (80 g) podría reemplazar parcialmente los granos de cereales y las fuentes de proteína de los concentrados de cabras lecheras hasta en un $44 \% \sin$ afectar a la utilización de los nutrientes, la fermentación ruminal o el rendimiento lechero, y adicionalmente mejoraría el perfil de FA de la leche.

El objetivo del Experimento 6 (Artículo 4) fue verificar la existencia de menores abundancias de ${ }^{15} \mathrm{~N}$ en la fracción ADIN en comparación con el $\mathrm{N}$ total y el $\mathrm{N}$ insoluble en solución neutro detergente (NDIN) en diferentes alimentos, así como determinar la magnitud de la posible contaminación nitrogenada del ADIN. Para ello se analizaron muestras de un cultivo de maíz (biomasa aérea, granos y raíces) y de dos cultivos de girasol (SF) (biomasa aérea y semillas), determinándose la abundancia en ${ }^{15} \mathrm{~N}$ así como el contenido en $\mathrm{N}$ total, NDIN y ADIN. Las muestras fueron marcadas con ${ }^{15} \mathrm{~N}$ 
mediante la feritlización con ${ }^{15} \mathrm{NH}_{4} \mathrm{NO}_{3} \mathrm{O} \mathrm{NH}_{4}{ }^{15} \mathrm{NO}_{3}$. Se utilizaron tres réplicas para cada tipo de muestra. La abundancia de ${ }^{15} \mathrm{~N}$ en el $\mathrm{N}$ total y NDIN fue similar $(\mathrm{P}>0,05)$ en todas las muestras, mientras que la abundancia en el ADIN fue menor $(\mathrm{P}<0,001$ a 0,037) en todas las muestras, a excepción de las semillas de SF de uno de los dos cultivos. Las estimaciones de la contaminación con $\mathrm{N}$ del ADIN a partir del bromuro de cetiltrimetilamonio (CTAB) no se vieron afectas por el tipo de fertilizante usado para marcar las muestras $(\mathrm{P} \geq 0,207)$, y los valores $(\mathrm{g} / \mathrm{g})$ oscilaron entre 0,129 para los granos de maíz hasta 0,447 para la biomasa aérea del maíz. La contaminación con $\mathrm{N}$ del ADIN estuvo correlacionada positivamente con el contenido en NDF, ADF, hemicelulosa y celulosa ( $\mathrm{P}<0,001 ; \mathrm{r}=0,770$ a 0,$905 ; n=18$ y 22 para maíz y SF, respectivamente), y negativamente $(\mathrm{P}<0,001$ a 0,048$)$ con el contenido en ADIN (expresado como proporción de la ADF). La correlación negativa $(\mathrm{P}<0,001)$ entre la contaminación con $\mathrm{N}$ del ADIN y la relación lignina ácido detergente (ADL)/ADF observada en todas las muestras indicaría que la contaminación del ADIN se reducía al aumentar el nivel de lignificación de la pared celular. En resumen, los resultados indican que el uso de CTAB en el análisis de la ADF aumenta el contenido en ADIN, y por ello sobreestimael contenido de $\mathrm{N}$ asociado a la $\mathrm{ADF}$, cuestionando el uso del ADIN como parámetro indicativo de la disponibilidad del $\mathrm{N}$. 

Chapter I. INTRODUCCTION 
$\sim 2 \sim$ 


\section{I.1. Introduction}

Spain is, after Italy, the second largest European fruit and vegetable producer, and the greatest exporter of these products in the European Union (EU). According to the Ministry of Agriculture, Fisheries and Food (MAPA, 2019a), the value of the production of the fruit and vegetable sector in our country is about 14,000 million of euros, and accounts for $47 \%$ of total vegetal production and $29 \%$ of the agricultural production. The fruit and vegetable sector has also a powerful processing industry that annually generates almost 9 million tons of by-products (skins, bones, pulps, stems, fruits wastes, etc.), as the proportion of wastes can range between 12 and $63 \%$ of the processed vegetables or fruits (Alfonso et al., 2010). These by-products usually have high content in water, organic matter $(\mathrm{OM})$ and nutrients, being easily putrescible and causing environmental pollution problems. The generation of these by-products is unavoidable and alternatives for later use are required, such as the extraction of bioactive compounds for human health and food, their use in farm animal nutrition or as fertilizers, or other options (Pascual Vidal, 2015). The use of agroindustrial by-products in animal feeding is currently one of the most valuable alternatives, as it would contribute to reduce feeding costs and the environmental contamination by incorporating into the production chain materials with high pollution potential. The use of agroindustrial by-products in animal feeding would also contribute to sustainability of livestock systems, reducing the carbon footprint of animal products due to their regional/local production (del Prado et al., 2013) and helping to close nutrient cycles locally (Pascual Vidal, 2015). By-products can also contain bioactive compounds that may improve not only animal health but also the quality of animal products, and may also reduce methane emissions contributing to decrease the environmental impact of livestock production (Romero-Huelva et al., 2012).

The use of any unconventional feed, such as agroindustrial by-products, in animal feeding requires precise information on its nutritional value. Matching the nutrient content in the diet to the nutrient requirements of the animals is a crucial point to optimize animal production and the quality of animal products, but also to reduce the environmental impact of livestock production. Therefore, the optimal inclusion of an unconventional feed in the diet requires investigations on its nutritional value and its impact on both the final product (meat, milk, etc.) and the environment. 
Ruminant animals can use fibrous by-products more efficiently than nonruminants, but the nutritive evaluation of their feeds is complex, especially when feeds have highly variable composition, as occurs with some agroindustrial by-products. These difficulties have contributed to the lack of data on the nutritive value of some agroindustrial by-products and data available in the literature are not always representative of those generated in our country. In addition, direct extrapolation of values obtained in one animal species to others is not appropriate, and a specific nutritive evaluation is required for each animal species. Whereas some agroindustrial by-products are well known and have been used successfully in animal feeding for decades (i.e., sugar beet pulp, corn distillery grains, ...), others are less used due to uncertainty regarding their availability, palatability, nutritive value and the risk of toxicity.

There are characteristics of some agroindustrial by-products generated in large amounts in our country that currently limit their practical use in animal feeding, and have also contributed to the limited data available on their nutritive value. One of these characteristics is their heterogeneity, which is due not only to the variability of the original raw material but also to the different processing methods used. As a consequence, values for chemical composition and nutritive parameters found in the literature for a single type of by-product have high coefficients of variation (CV) (Feedipedia, 2019; DePeters et al., 2010; De Blas et al., 2010) that prevent their inclusion in the diets without previous analysis. Another aspect that complicates their routinely use in practical feeding is that some by-products are markedly seasonal, so that their production accumulates in a short period of time and a conservation procedure is required; however, conservation procedures usually increase the price of by-products and frequently makes their use not worthwhile. The practical use of a by-product in animal feeding depends on numerous factors, but its nutrient content, availability, price, and ability to be stored, often determined by its water content, are the main factors.

In ruminants most of digestion occurs in the reticulum-rumen, and therefore the characterization and quantification of final products of rumen fermentation is a crucial point for nutritive evaluation and the formulation of balanced diets. The study of ruminal fermentation in vivo requires expensive, laborious and long-term trials. These problems, together with the increased public awareness of animal rights and the need for decreasing the number of fistulated animals used for experimental purposes, have 
contributed to the increasing use of in vitro techniques for nutritive evaluation (Carro et al., 2009).

The objective of this literature review is to analyze the state of the art on production and nutritive value of two agro-industrial by-products generated in large amounts in Spain (olive cake (OC) and tomato pomace (TP)) and on their effects on animal performance and quality of animal products when they are fed to small ruminants. Additionally, it includes short review on the production and use of citrus pulp and dried distillers grains with solubles (DDGS) on ruminant feeding, as these two by-products were used in one experimental trial of this Doctoral Thesis. Finally, the nutritional significance of the acid detergent insoluble nitrogen (ADIN) fraction of feeds is revised, as the ADIN analysis is used by some ruminant feeding systems as a measure of nitrogen $(\mathrm{N})$ availability. Some agroindustrial by-products are generated in processes involving heating, which can increase their ADIN content (Vanegas et al., 2017), and ADIN is widely accepted as a good measure of heat damage in feeds (NRC, 2001; Goering et al., 1972).

\section{I.2. Olive cake}

\section{I.2.1. Olive cake production}

Olive oil production is continuously increasing worldwide, but most of the production is concentrated in the Mediterranean countries and Spain, Greece, Italy and Tunisia are the greatest producers (Consejo Oleícola Internacional, 2018). Spain is the world's leading olive oil producer, with an average production of 1.2 millions of tons per season between 2007 and 2013, which was increased by 23\% compared to that in the previous decade. This figure represents $60 \%$ of the oil produced in the EU and $45 \%$ of the total in the world (MAPA, 2018). About 6.5 millions of $t$ of olives were produced in Spain in 2018, being 91\% of them used for olive oil production and only 9\% consumed as table olives (MAPA, 2018). Olive oil production generates different byproducts, such as OC, olive leaves, olive stones, and molasses (Molina-Alcaide and Yáñez-Ruiz, 2008). The generation of OC is later described. Olive leaves are a mixture of leaves and branches which are generated during the harvesting of olives and the cleaning of olive trees, whereas olive stones are obtained by separation from the pulp and are used as energy source. Finally, molasses are the dried and transformed watery waste produced during the oil extraction (Molina-Alcaide and Yáñez-Ruiz, 2008). The 
traditional method of oil extraction (Figure 1) consists of a three-phase extraction and in this process $100 \mathrm{~kg}$ of olives generates about $55 \mathrm{~kg}$ of wastes (Molina-Alcaide and Yáñez-Ruiz, 2008). Two types of wastes are generated in this process: an olive oil mill solid waste with a moisture content of around $40-50 \%$, and huge quantities of wastewater, which is the main pollutant. Several biological, physiochemical and oxidation treatments have been developed to reduce the pollutant effects of the wastewater (Paraskeva and Diamadopoulos 2006). On the other hand, the solid waste still contains small amounts of oil, and normally undergoes a second oil extraction using hexane or other chemical solvents. Afterwards, the solid waste consists primary of lignin and cellulose, and is marketed either as mulch for olive trees or as a solid fuel (Rodríguez et al., 2008; Vlysides et al., 2004). Currently, the most used olive oil extraction system in Spain is the two-phase system, in which no water is used, less energy is needed, and the wet waste generated contains less oil due to the greater efficiency of the extraction process (Alburquerque et al., 2004). This system decreases the amount of highly polluting wastewater, but generates a high-moisture $(50-70 \%$ water) solid by-product known as "alperujo" (Centro de Actividades Regionales para la Producción Limpia, 2000). It is estimated that only 20 to $27 \%$ of the processed olive turns into oil, while the rest are by-products generated in the process (Awawdeh and Obeidat, 2013). The "alperujo" is a mix of stone pieces, rest of pulp from the olive fruits, and variable amounts of water and oil, and has a high pollution potential. Olive oil production is highly seasonal and great amounts of "alperujo" are generated during the olive oil campaign (Alburquerque et al., 2004). The "alperujo" is sent to the "orujeras" where is stored in large ponds. Subsequently, the "alperujo" is dried and the bones are removed to obtain the crude OC (COC) that is mainly composed of the rest of the pulp and stones, the olive skin, and water (Molina-Alcaide and Yáñez-Ruiz, 2008). It is calculated than in Spain, between 25 and $40 \mathrm{~kg}$ of COC are generated per $100 \mathrm{~kg}$ of processed olives, accounting for a total production of about 300,000 t per year (De Blas et al., 2010). 


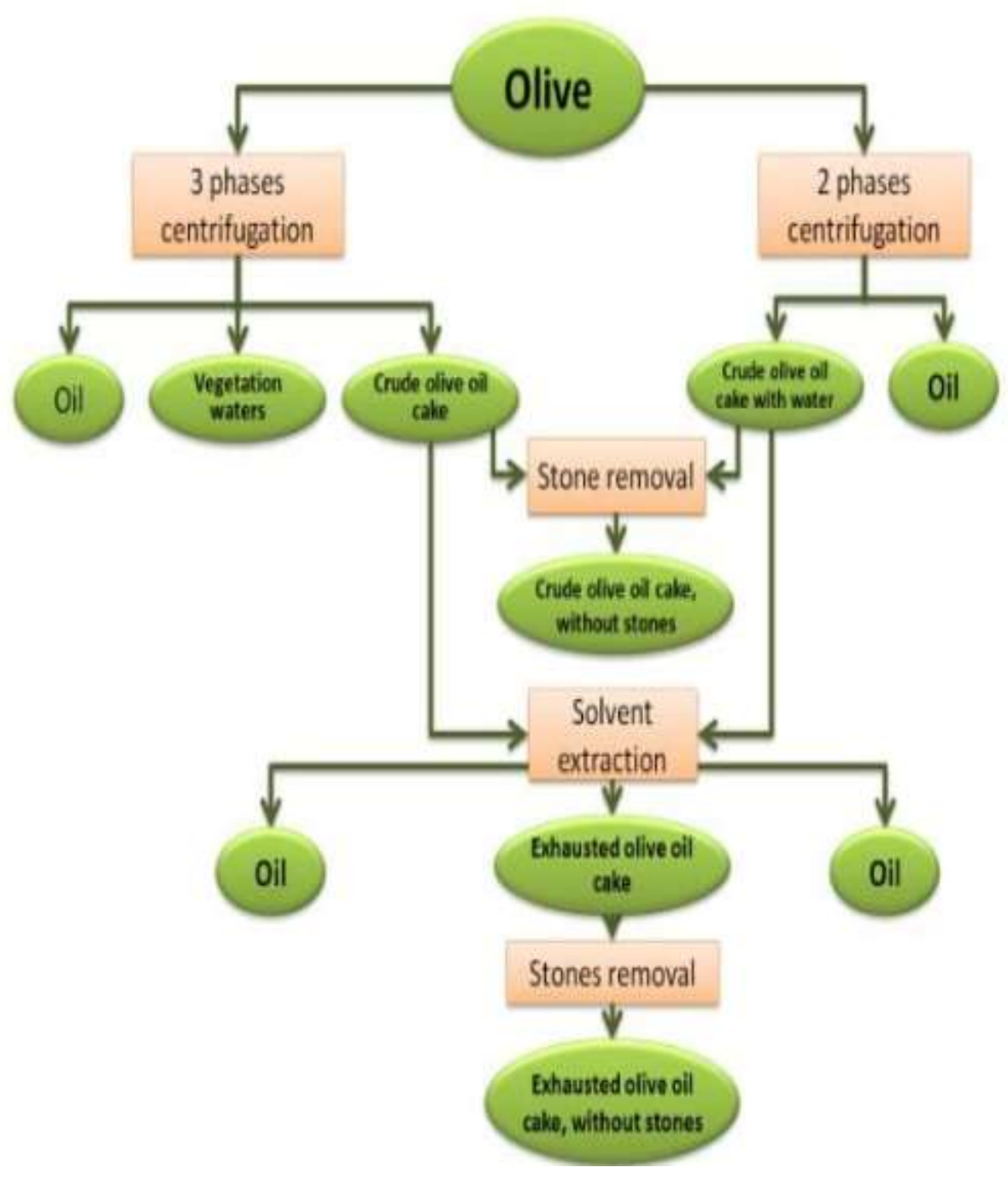

Figure 1. Phases of olive oil extraction and by-product production (Habeed et al., 2017).

Chemical composition of COC is highly variable and depends on the content of oil and wastewater. The COC can be subjected to a second chemical extraction, either with hexane or with other authorized food-grade solvents, to extract the residual oil that is marketed as "pomace oil", and the resulting by-product is called exhausted OC (EOC. In the last part of this process, the solvent is "flashed off" by heating. The chemical composition of EOC differs from that of COC, and is markedly affected by the extraction procedure (De Blas et al., 2010).

The chemical composition of COC is influenced by the chemical composition of the olive fruits and their characteristics, such as the content of skin, pulp and stones, but also by the added water and the amount of oil extracted during the processing to obtain the oil. The edible portion of the olives is mainly composed of water and lipids, which 
can range from 14 to $30 \%$ depending on the cultivar and the ripening stage (Bianchi, 2003). Olives have a high content of monounsaturated fatty acids (MUFA), especially oleic acid (47-87\%) and important amounts of polyunsaturated fatty acids (PUFA), such as linoleic and linolenic acids. On the contrary, the content of sugars is low compared with other fruits (Servili et al., 2016). Phenolic compounds are also present in olives, although the amounts are variable (1-3\%), and the most abundant are oleuropein, demethyloleuropein, hydroxityrosol and verbascoside (Romero et al., 2017; Servili et al., 2016; Blekas et al., 2002).

The oil extraction procedure also affects the chemical composition of $\mathrm{COC}$, as influences the proportion of pulp, stones, water and remaining oil (De Blas et al., 2015; Vlyssides et al., 1998). In addition, the quality of the olive and the extraction efficiency are related with the composition and texture of the olive fruits (Rallo et al., 2018). Another source of variation is the genetic selection programs which are directed towards an increase in the yield of olive oil, and therefore differences in chemical composition between industrial and traditional olive fruits are expected. Soil properties affect water availability, which in turn can affect fruit ripeness (Rallo et al., 2018) and therefore the composition of the generated COC. The type of soil in which olive trees are cultivated also influences the mineral composition of olive fruits (Rallo et al., 2018), as well as climatic conditions. Thus, low temperatures (below $-3{ }^{\circ} \mathrm{C}$ ) have been reported to affect the oxidative processes (Sanzani et al., 2012), decreasing the concentration of most phenolic compounds. On the contrary, high temperatures during the ripening period have a negative effect on fruit weight, oil content, and even fatty acid (FA) composition, as oleic acid decreases (García-Inza et al., 2014). The altitude at which olive trees are cultivated also influences FA composition and phenols content. Strong droughts rea reported to affect negatively the fruit size and the pulp/stone ratio, and therefore, irrigation increases the water content, fruit size and the pulp/stone ratio (Rallo et al., 2018). Other factor that can affect the chemical composition of COC is the inclusion of other substances during the processing of olive fruits. The processing olive fruits with high moisture (>50\%) and low non-fat dry matter (around 25\%) generates a mixture called "difficult pastes", that have a negative effect on the extraction process, as they form oil-water emulsions that reduce the efficiency of oil extraction and part of the oil is lost with the residues (Rallo et al., 2018). This negative effect can be minimized by including substances such as talc (hydrated magnesium silicate) that can modify the 
composition of COC (Koprivnjak et al., 2016; Canamasas and Ravetti, 2014).

\section{I.2.2. Chemical composition and characteristics of olive cake}

In general, $\mathrm{COC}$ is characterized by high fibre, polyphenols and fat content, with an average of $54.5 \mathrm{~g} / \mathrm{kg}$ dry matter (DM) (Molina-Alcaide and Yáñez-Ruiz, 2008), being especially rich in oleic acid (Chiofalo et al., 2004). The content in neutral detergent fibre (NDF) and acid detergent lignin (ADL) is usually high and can reach up to 795 and $320 \mathrm{~g} / \mathrm{kg} \mathrm{DM}$, respectively. The degradability of the NDF is low, with values that are usually below 30\% (De Blas et al., 2010). The crude protein (CP) content is rather low (from 48 to $106 \mathrm{~g} / \mathrm{kg} \mathrm{DM}$ ) and it is worth noticing that most $\mathrm{CP}$ is bound to the acid detergent fibre (ADF) (Kotsampasi et al., 2017). Removing the stones of the OC can improve its nutritional value, as fibrous components vary largely with the proportion of stones in OC (Molina-Alcaide and Yáñez-Ruiz, 2008) and stones can cause injuries to the digestive epithelium of the animals (De Blas et al., 2010). Yansari et al. (2007) found that destoning and exhausting of olive cake significantly increased $\mathrm{CP}, \mathrm{N}$-free extracts and non-fibrous carbohydrates content, and reduced its fat, NDF, $\mathrm{ADF}$ and ADL contents.

There are marked differences between types of OC, being the fat content one of the most important. Whereas COC usually has a high fat content with a high proportion of oleic acid (Chiofalo et al., 2004), the EOC obtained after the second oil extraction has lower fat content, but a greater amount of $\mathrm{CP}$ bound to the ADF due to the heat treatments that can cause Maillard reactions (Álvarez-Rodríguez et al., 2009). The extraction temperature can also cause a loss of lipophilic antioxidants and other bioactive compounds, such as phenolic compounds (Martín-García et al., 2003; Amro et al., 2002). These compounds are important, as they can improve the meat quality by increasing its oxidative stability when OC is used in the feeding of meat production animals. On the contrary, the drying temperature of the "alperujo" to obtain the COC does not affect the content of bioactive compounds, but can modify the FA profile (Uribe et al., 2013). Some studies have reported differences between COC and EOC in the amount of phenolic compounds (Molina-Alcaide and Yáñez-Ruiz, 2008), but the phenolic content is also affected by the chemical composition of the olive fruit caused by agronomical factors (Romani et al., 1999), the ripening of the fruit (Amiot et al., 1986), climatic conditions (Vinha et al., 2005) and irrigation management (Patumi et al., 
2002), among other factors.

The production of olive by-products is highly seasonal, and in order to use them in animal feeding, an efficient preservation and storage is required. One of the drawbacks of employing COC in animal nutrition is its high moisture content, which causes storage problems and environmental issues (Arco-Pérez et al., 2017). A possible solution to overcome these problems would be drying the $\mathrm{COC}$, but the treatment is expensive. Other solutions include feeding COC fresh, ensiled, or as a component of concentrate pellets or feed blocks, especially in ruminant diets (Panagiotis et al., 2018), and several studies have analysed these options. Ensiling COC is an adequate and cost-effective technology that, additionally, can improve the nutritional quality of the ensiled feed (Meneses et al., 2007). The COC silages can include poultry manure, conventional feeds, urea or alkali (Molina-Alcaide and Yáñez-Ruiz, 2008). Arco-Pérez et al. (2017) showed that silages including oil by-products and sunflower can be included in the diet of dairy goats with no negative effects on rumen fermentation or milk production and increased the nutritional value of the milk. Another option might be the inclusion of COC into feed blocks, which are a simple, low cost and efficient technique for longterm storage of high-moisture by-products, consisting in a solidified mixture of feed ingredients, urea, binder and salt (Ben Salem and Nefzaoui, 2003). Molina-Alcaide et al. (2010) observed that replacing partially the concentrate of dairy goats with feed blocks including COC had no negative effects on nutrient utilization and improved milk quality. In another study, Ben Salem and Znaidi (2008) fed feed blocks containing 44\% of COC to lambs and observed no negative effects on growing performance.

\section{I.2.3. Nutritive value of olive cake}

All types of OC are characterized by low nutritive value (Sansoucy et al., 1985), as they usually have high content of NDF and ADF (Martín-García et al., 2003; Nefzaoui, 1983) and low degradability of the cell wall (Yansari et al., 2007; Filya et al., 2006). The low degradability can be improved by the treatment with polyethylene glycol (PEG) and $\mathrm{NaOH}$ and (Molina-Alcaide and Yáñez-Ruiz, 2008; Molina-Alcaide and Aguilera, 1988). Moreover, OC contains antinutritive compounds, such as polyphenols and tannins, which may decrease both its palatability and digestibility (Makkar, 2003). The low nutritional value of OC makes its use in high-yielding dairy cows inefficient (Chiofalo et al., 2004), but its utilization in dairy ewes and goats is possible, as they 
have developed specific mechanisms in order to utilize low-quality feeds (Lanzani et al., 1993). Yáñez-Ruiz et al. (2004a) reported that ruminal environment of goats is more efficient in fermenting diets including OC than that of sheep. Nevertheless, the specific knowledge about the nutritive value of different types of $\mathrm{OC}$, such as the factors influencing its chemical composition and the intestinal digestibility of the rumen undegraded protein, is still scarce.

Martín-García et al. (2003) reported values of effective rumen degradability for CP of OC ranging from 0.38 to 0.44 measured in situ in sheep, but the values increased up to 0.51 with PEG treatment. These values, together with the low CP content of OC indicate a low supply of $\mathrm{N}$ for ruminal microoganisms. Similarly, degradabilities of OM and ADF are reported to be low, with average values of 0.51 and 0.37 , respectively, but these can be improved when $\mathrm{OC}$ is treated with ammonia or $\mathrm{NaOH}$ (Nefzaoui and Vanbelle, 1986). On the contrary, the rumen degradability of amino acids was reported to be high ( 0.90 as average), and among them, lysine, phenylalanine, threonine, tyrosine, isoleucine and leucine had the greatest degradability values and cysteine the lowest. (Molina-Alcaide and Yáñez-Ruiz, 2008). Reported values for total and amino acid-N content of the rumen undegraded fraction of $\mathrm{OC}$ are 10.8 and $7.30 \mathrm{~g} / \mathrm{kg} \mathrm{DM}$, accounting for 0.612 and 0.431 of total N, respectively (Martín-García et al., 2003). The most abundant amino acid in this fraction were glutamic acid, alanine and valine, whereas histidine, tyrosine and lysine has the lowest concentrations. The apparent intestinal digestibility of the most abundant and least abundant amino acids were 0.86 and 0.37, respectively (Martín-García et al., 2004).

Studies of rumen fermentation parameters in animals fed OC are limited. Nefzaoui (1985) observed that ruminal concentrations of $\mathrm{NH}_{3}-\mathrm{N}$ in sheep fed EOC were below the recommended minimum values for an optimal microbial activity (Firkins et al., 2007). However, other studies have obtained better results by introducing OC in concentrate formulation. Thus, Yáñéz-Ruiz et al. (2004b) partially replaced alfalfa hay with a concentrate that included OC, and they observed similar nutritive value and digestibility than with a medium quality diet. It has been reported that pelleting OC reduced the OM digestibility, probably due a decrease in rumen retention time caused by the reduction in particle size (Molina-Alcaide and Aguilera, 1988). The digestibility of OC varies depending on the type of OC, but the digestibility of OM and CP are generally low, whereas the digestibility for ether extract (EE) is usually high $(0.60-0.90)$ 
regardless of the OC type or the processing method used (Theriez and Bouler, 1970).

\section{I.2.4. Effects of feeding olive cake to meat-producing ruminants}

Despite the low nutritive value reported for OC, many studies have investigated the effects of its inclusion in the diet in dairy and meat goats and sheep, with contrasting results. As pointed out by Molina-Alcaide and Yáñez-Ruiz (2008), from a practical standpoint, it is necessary to differentiate between COC and EOC. Tufarelli et al. (2013) reported no negative effect in the productive performance of lambs when they were fed a diet containing $20 \%$ of EOC in replacement of oat hay and soybean meal, and Kotsampasi et al. (2017) obtained similar results in lambs fed up to $24 \%$ of EOC. Sadeghi et al. (2009) also reported that dietary inclusion of $20 \%$ of EOC did not have any negative effect on lamb performance, but increased DM, NDF and CP digestibility. Other studies also showed that including up to $25 \%$ of $\mathrm{COC}$ in the diet had no detrimental effects on intake and growth of lambs (Awawdeh and Obeidat, 2011; AlJassim et al., 1997; Giozelgiannis et al., 1978) and goat kids (Hadjipanayiotou, 1994). In contrast, Mioč et al. (2007) observed that including 30\% of COC in the diet of lambs decreased significantly daily gain, final weight, empty carcass weight and dressing percentage of lambs. When feeding high amounts of COC to ruminants it has to be taken into account that high concentrations of unsaturated FA can have negative effects on rumen microbiota, especially on cellulolytic activity (Maia et al., 2007).

The effects of OC on meat quality and FA profile of lambs has been investigated in different studies (Mele et al., 2014; Vera et al., 2009), and the results indicate that OC can increase meat quality. One of the main challenges in the meat sector is the preservation of quality during meat storage and retail display by delaying lipid oxidation, which is the major cause of meat deterioration (Faustman et al., 2010). The oxidative stability is highly dependent on the balance between muscle antioxidant and pro-oxidant components. The antioxidant components include, among others, tocopherols and carotenoids (Descalzo and Sancho, 2008). On the other hand, the PUFA in meat, especially those in the phospholipid fraction of cell membranes, are easily oxidized and some might act as pro-oxidants (Morrissey et al., 1998). The PUFA content in meat is especially interesting, because of their beneficial effects on human health. The intake of antioxidants in the diet can modify both the antioxidant and the pro-oxidant components of the muscle and protect PUFA from oxidation. Generally, 
ruminant diets have low content in antioxidants, and thus meat is highly susceptible to oxidative deterioration (Luciano et al., 2012). Feeding concentrates with PUFA sources, such as linseed, is a common practice to increase PUFA concentration in the intramuscular fat. However, feeding PUFA sources without increasing the intake of antioxidants can have negative effects in terms of the oxidative stability of meat (Jacobsen et al., 2008). Compounds present in the OC, especially those in EOC, might influence the oxidative stability of meat. For example, Luciano et al. (2013) investigated the use of stoned COC ( $24.5 \%$ of the diet) combined with linseed in the diet of lambs to enhance the oxidative stability of PUFA-enriched meat. The results of this study demonstrated that the inclusion of COC had no detrimental effect on growth, carcass weight or muscle fat content, and the meat had higher stability to oxidation compared with the meat from lambs fed the diet including linseed without COC.

Several studies have reported changes in meat FA profile when ruminants were fed OC. Kotsampasi et al. (2017) observed a decrease in lauric acid and a slight increase in pentadecanoic acid in the meat of lambs fed a concentrate with $24 \%$ EOC as a result of different FA profile in the diet. These authors also observed an increase in $\alpha$-linoleic acid in the intramuscular fat of the lambs fed the EOC, even though the content of $\alpha$ linoleic in the concentrate did not differ with those of the control. Oleic, $\alpha$-linoleic and $\alpha$-linolenic acid undergo the same biohydrogenation pathways to produce primarily trans FA and stearic acid (Wood et al., 2008; Doreau and Ferlay, 1994), and as a consequence of the greater oleic acid content in the EOC concentrate, greater amounts of $\alpha$-linolenic could have escaped rumen biohydrogenation, as oleic acid was the main substrate for biohydrogenation. Tannins can also influence the concentration of $\alpha$ linoleic acid in the intramuscular fat of lambs, because they can inhibit the activity of some ruminal microorganisms, hence reducing the ruminal FA biohydrogenation (Vasta et al., 2009).

\section{I.2.5. Effects of feeding olive cake to dairy ruminants}

The results on the influence of olive cake feeding on milk yield and composition are also controversial. Many studies (reviewed by Molina-Alcaide and Yáñez-Ruiz, 2008) have reported that the performance of diary ewes fed concentrates including OC is similar or even better than that of sheep fed concentrates with conventional feed ingredients, but negative effects have been observed in others. For example, Chiofalo et 
al. (2004) reported an increase in milk yield when $20 \%$ of COC was included in the diet of dairy ewes, Vargas-Bello-Pérez et al. (2013) observed no effect on milk yield by including up to $25 \%$ of COC in the diet of dairy ewes, and Molina-Alcaide et al. (2010) found a decrease in milk yield in goats fed a diet containing 12\% of COC. Although several factors can be involved in the variable response observed in these studies, differences in the composition of OC can help to explain these results.

The FA profile of ruminants milk is highly dependent on FA composition and fibre content of the diet (Vasta et al., 2008), although dietary PUFA are modified by an intense microbial biohydrogenation activity (Bauman and Griinari, 2003). The composition of the diet can also influence the concentration of fat-soluble micronutrients, such as $\beta$-carotene and $\alpha$-tocopherol (Martin et al., 2004), and of plant secondary metabolites like phenolic compounds (O'Connell and Fox, 2001) in the milk of ruminants. This compounds can help to reduce the photo-oxidation of the milk fat globule membrane, which is the major site of auto-oxidation (O'Connell and Fox, 2001; Lindmark-Mansson and Akesson, 2000). Moreover, the presence of these compounds in the milk can increase its organoleptic and nutritional qualities (Noziere et al., 2006; O'Connell and Fox, 2001). Olive cake contains considerable amounts of plants secondary metabolites, such as different types of polyphenols (Vasta et al., 2008). The intake of these bioactive compounds is considered beneficial for human health as they reinforce the natural defense system, decreasing the formation of free radicals and the detrimental oxidative events in the metabolism (Parr and Bolwell, 2000). Thus, a transfer of these bioactive compounds to the milk is desired. The main antioxidative compounds in milk are enzymes, lactoferrin, vitamins $\mathrm{C}$ and $\mathrm{E}$, and carotenoids (Noziere et al., 2006) and, to a lower degree, phenolic compounds (O'Connell and Fox, 2001). O'Connell and Fox (2001) reported that ruminant milk has considerable amounts of phenolic compounds, most of which are of dietary origin. Some studies showed that dietary polyphenolic compounds can modify PUFA rumen biohydrogenation with no negative effect on milk yield and quality (Buccioni et al., 2015; Ferlay et al., 2010). As a consequence, OC can modify milk FA composition by modulating ruminal biohydrogenation (Vasta et al., 2008).

Olive cake is characterized by high MUFA content (mainly oleic acid), and its inclusion in the diet of dairy ewes has been shown to reduce saturated FA (SFA) and increase MUFA content in milk (Vargas-Bello-Pérez et al., 2013; Chiofalo et al., 2004). 
Abbeddou et al. (2011) reported that the inclusion of 30\% of OC in the diet of dairy ewes decreased the amount of short- and medium-chain SFA in the milk. A decrease in medium-chain SFA (C12:0, $\mathrm{C} 14: 0$ and $\mathrm{C} 16: 0)$ is considered beneficial for human health, as they have been related to increases in total and low density lipoprotein cholesterol concentrations (Williams, 2000). Both short- and medium-chain SFA are mainly synthesized de novo in the mammary gland and this process can be partly inhibited by long-chain FA (either from diet or body fat mobilization) and by trans FA from hydrogenated dietary fat or conjugated linoleic acid (CLA) supplements. The oleic acid present in the milk is mainly generated by mammary $\Delta 9$-desaturation of stearic acid (C18:0), but it can be transferred from the diet to the milk to a certain extent (Chilliard et al., 2007). This would explain the reason for greater concentrations of oleic acid in the milk of ruminants fed diets including OC (Chiofalo et al., 2004). Likewise, greater concentrations of stearic acid in the milk from ruminants fed $\mathrm{OC}$ are expected as a result of the greater oleic acid content in the diet. Oleic acid is regarded as a beneficial FA to human health (Dewhurst et al., 2006), whereas stearic acid is considered to have no effect on cholesterol values in the consumers of milk and dairy products. Stearic acid in milk has two main sources: the diet and the complete ruminal biohydrogenation of 18-PUFA (Gomez-Cortes et al., 2008; Chilliard et al., 2007). The biohydrogenation of oleic acid in the rumen generates stearic acid, together with a variety of 18:1 trans acids, with the exception of 18:1 trans 11 . On the contrary, trans FA in milk is undesirable, as the intake of these acids is a risk factor for coronary heart disease and diabetes in consumers (Salmeron et al., 2001).

During the olive oil extraction process, more than $98 \%$ of total olive polyphenols end up in the wastewater. These polyphenols can be extracted to obtain a product rich in oleuropein-aglycone di-aldehyde and verbascoside (Servili et al., 2011), that can be used in animal nutrition to reduce the ruminal biohydrogenation and modify the FA profile of milk. Capucci et al. (2018) observed that supplementing dairy ewes diets with this olive crude phenolic concentrate and linseed did not have any detrimental effect on milk yield, but increased the content of $\alpha$-linoleic acid in milk.

In conclusion, large amounts of COC and EOC are produced in our country and their use in ruminant feeding is a viable alternative to recycle them. Replacing conventional feeds by COC and EOC would help to reduce the environmental pollution caused by wastes disposal in the olive industry and contribute to sustainability of 
ruminant farms by reducing feeding costs. The inclusion of $\mathrm{OC}$ in ruminant diets could also positively influence the quality and antioxidant capacity of meat and improve milk FA profile with no detrimental effects on productivity. However, more information on factors influencing chemical composition and nutritive value of $\mathrm{OC}$ is needed to facilitate its use in practical ruminant feeding.

\section{I.3. Tomato pomace}

\section{I.3.1. Tomato pomace production}

Tomato is one of the most common crop worldwide, and the fruits are rich in lycopene, phenols, organic acids, vitamins and other components (Giovanelli and Paradiso, 2002). According to the FAO statistics (FAO, 2016), tomatoes are mainly produced in China $\left(5.64 \times 10^{7}\right.$ tonnes $)$, America $\left(2.61 \times 10^{7}\right.$ tonnes $)$, India $\left(1.84 \times 10^{7}\right.$ tonnes), Turkey $\left(1.26 \times 10^{7}\right.$ tonnes), Egypt $\left(7.94 \times 10^{6}\right.$ tonnes $)$, Italy $\left(6.44 \times 10^{6}\right.$ tonnes $)$, Iran (Islamic Republic of) $\left(6.37 \times 10^{6}\right.$ tonnes $)$, Spain $\left(4.67 \times 10^{6}\right.$ tonnes $)$, Brazil $\left(4.17 \times 10^{6}\right.$ tonnes), and Mexico (4.05 $\times 10^{6}$ tonnes). The total planting area was approximately $4.8 \times 10^{6}$ ha, with a production of approximately $1.8 \times 10^{8}$ tonnes (Lu et al., 2019).

Tomato cultivation currently occupies a total of 54,675 ha in Spain, which represents $15 \%$ of the area dedicated to vegetable production, and has an annual production over 4.8 million tons of tomatoes (MAPAMA, 2018). More $60 \%$ of total production is consumed fresh and the rest is processed to generate different products, such as paste, juice, sauce, puree and ketchup (Calsamiglia et al., 2016).

Tomato pomace is the by-product of tomato processing, and is made up of a mixture of peels, crushed seeds and small amounts of pulp that remain after processing to produce juices, creams, sauces, etc. (Ventura et al., 2009). Tomato pomace can represent between 3 and $6 \%$ of the original fruit weight (Del Valle et al., 2006), and has a high percentage of humidity $(>70 \%)$ due to the water added in the final stage of the process to facilitate the exit through the ducts to the storage hoppers (Mendez-Llorente et al., 2014; López-Parra et al., 2011), which difficult its conservation (López-Gallego et al., 2015). Tomato pomace can be dried before being stored or transported, but artificial drying substantially increases its price. For this reason, a large part of the byproduct produced is discarded or used fresh for animal feeding in farms located close to the processing plants (Mendez-Llorente et al., 2014; Denek and Can, 2006). As an 
alternative, TP can be ensiled and constitutes a cheap source of energy and nutrients. The seasonal production of TP is linked to the tomato harvest period (Feedipedia, 2018), and if the wastes are not used, they not only cause a disposal problem, but also aggravate environmental pollution (Del Valle et al., 2006).

Like most agroindustrial by-products, the chemical composition of TP is highly variable depending on external factors, such as the variety of the crop, maturity of the fruit and growth conditions, and processing practices ( $\mathrm{Lu}$ et al., 2019). For example, Kiosseoglou and Boskou (1989) reported that the FA profile of TP might differ among different cultivars, and Brodowski and Geisman (1980) observed that amino acid profile in tomato seeds was not influenced by fruit maturity, but the total amino acid content decreased as fruit maturity increased. Herrera et al., (2010) reported differences in fructose and glucose content in tomato peels between harvest years. Even though there are multiple factors that can affect the chemical composition of $\mathrm{TP}$, it seems that two factors can stand out among the others: the final product form and the peeling method applied (Lu et al., 2019). For example, in the production of canned tomatoes, the TP is constituted exclusively of peels. On the other hand, the TP obtained when tomatoes are transformed into homogenized products such as paste, sauce or ketchup, contains a mixture of peels, seeds and a small amount of pulp. In the production of canned tomatoes, the peels are collected directly as TP, whereas in the production of homogenized products, the whole fruit is pressed and the remained material is collected, the seeds accounting for approximately $45 \%$ of the resulting TP (Kaur et al., 2005). However, in both cases peeling is an important process influencing TP chemical composition.

There is a lot of information related to the process of tomatoes peeling, and it is currently an active topic of research for food scientists. The traditional methods of peeling include hot lye and steam processes. In the hot lye peeling process, the outermost layer of tomatoes is dissolved and the lye penetrates the exocarp, causing the degradation of the cell wall components and the middle lamella between the epidermal and hypodermal cells, which leads to the stripping of tomato skins under specific friction or pressure washing (Rock et al., 2012). In the steam peeling method, complex thermal-biochemical changes are produced in the epidermis on pectinaceous, polysaccharide and cutin substances. Simultaneously, heating provokes pressure on the tomato body (García and Barrett, 2005), and this separates the peel from the tomato 
pulp, making easier to remove the peel. Nonetheless, both processes represent a major environmental burden and other more environmental friendly peeling methods are currently being used, such as infrared, ohmic, ultrasonic and enzymatic peeling methods. Differences in lycopene content have been reported depending on the peeling process (Brown et al., 1970), and when different crushing methods were applied, the resulting tomato peels samples had different particle sizes and content of insoluble and soluble dietary fibre (Wang et al., 2016).

\section{I.3.2. Chemical composition and characteristics of tomato pomace}

Tomato pomace is mainly composed of peels and seeds, although it also contains variable amounts of residual pulp. Peels and seeds differ in chemical composition, and therefore chemical composition of TP is markedly influenced by the proportion of each component. Tomato peels are rich in fibre, lycopene and phenols, whereas the seeds are rich in fat and protein. The content of dietary fibre in tomato peels is high, ranging from 62.9 to $88.5 \%$, with $1: 5$ ratios of soluble dietary fibre/insoluble dietary fibre (NavarroGonzález et al., 2011). This ratio is much lower than that reported for orange peels $(1: 1$; Talens et al., 2017) and this suggests tomato peels have a low content of pectin and a high content of cellulose. However, pectin content in tomato peels has been reported to be variable (Alancay et al., 2017). Tomato peels are a good source of lycopene, with a concentration that can reach up to $0.288 \%$ (Zuorro and Lavecchia, 2013). On the contrary, reported values for lycopene content in tomato seeds are lower $(0.013 \%$; Knoblich et al., 2005), although seeds contain relatively high amounts of phenols $(0.158 \%)$ and of caffeic, procatchoic, vanillic, catechein and gallic acids (Elbadrawy and Sello, 2016), ferulic, sinapic, chlorogenic, $p$-coumaric, and trans cinnamic acids (Valdez-Morales et al., 2014), as well as of flavonoids such as quercetin-3-O- $\beta$ glucoside, rutin, iso-rhamnetin, kaempferol, naringenin, quercetin, apigenin and myricetin. Tomato seeds have low content of dietary fibre and their fat content can range between 17.8 and 24.5\% (Mechmeche et al., 2017; Giuffrè and Caposcasale, 2016; Yilmaz et al., 2015). Tomato seed fat is rich in linoleic, oleic, palmitic, stearic and arachidic acids, and has a high proportion of unsaturated FA, reaching as average $80 \%$ of total FA. The most abundant FA is linoleic acid (37.6-72.7\% of total FA) followed by oleic acid (15.5-29.7\%; Yilmaz et al., 2015; Botineştean et al., 2014; Kamazani et al., 2014; Cantarelli et al., 1993). The other main component in tomato seeds is protein, which accounts for 23.6 to $40.9 \%$. Glutamic acid is the most abundant 
amino acid (19.4-24.4\%) followed by aspartic acid (8.82-10.3\%; Latlief and Knorr, 2010). Compared with cereals protein, tomato seeds have greater levels of lysine (3.45.9\% vs < 1\%; (Mechmeche et al., 2017; Latlief and Knorr, 2010; Lumpkins and Batal, 2005).

As stated before, the chemical composition of TP is highly variable depending on many factors, but the seeds/peel ratio is the major one. Tomato pomace has low DM content, which can vary between 15 and $34 \%$ depending on the amount of water added during processing to facilitate the transport of the pulp through the outlet ducts.

Barroso et al. (2017) observed that TP has a moderate nutritional value and reaches, in some cases, protein contents greater than $18 \%$ of DM. Composition in essential amino acids of TP is similar to soybean meal protein, but intestinal digestibility of the undegradable fraction might differ (Drouliscos, 1976). In addition, TP has a high content in FND and FAD (as average 58 and 51\%, respectively) and an appreciable content (9\%) of fat (Calsamiglia et al., 2016). However, its lignin content is high and can exceed 20\% of the DM (Feedipedia, 2018; Marcos et al., 2017), which reduces the degradability of the fibre. Tomato pomace contains numerous biologically active substances (lycopene, phenols, flavonoids...), that have antioxidant, hypolipidemic and anticarcinogenic activites (Sánchez-Zapata et al., 2004), being lycopene one of the most abundant. Lycopene is a non-provitamin A carotenoid that is responsible for the red color of tomatoes. The antioxidant effects of lycopene include a considerable reactive oxygen species scavenging activity, which prevents lipid peroxidation and DNA damage and enhances the cellular antioxidant defense systems (Kelkel et al., 2011). Therefore, TP is considered an intermediate energy and protein source for animal feeding, and a valuable source of bioactive compounds such as lycopene, vitamins C and E, phenols, and other carotenoids (Belović et al., 2016).

\section{I.3.3. Nutritive value of tomato pomace}

Tomato pomace has a moderate nutritional value, but has some special characteristics that makes it a valuable by-product for ruminant feeding, such as its high $\mathrm{CP}$ and EE content. Neutral detergent fibre and ADL content are also high, and are responsible for the moderate $\mathrm{OM}$ digestibility values. Average in vivo OM digestibility of $\mathrm{TP}$ has been reported to be $56 \%$ and ruminal $\mathrm{OM}$ degradability was $48.0 \%$ (Abbeddou et al., 2011, Gasa et al., 1989). Values measured in situ for DM 
degradability ranged from $38.9 \%$ (Fondevila et al., 1994) to 62.0\% (Ben Salem and Znaidi, 2008). A wide range of values of in situ ruminal degradability of CP of TP has been reported. Abbeddou et al. (2011) and Salem and Znaidi (2008) reported high values that ranged between 65 and 78\%, whereas Fondevila et al. (1994) reported values of $40.6 \%$. Ventura et al. (2009) reported much lower values of CP degradability in tomato fruits wastes $(<20 \%)$. These differences are probably related to variability in chemical composition of TP, but might be also due to differences in the in situ procedure, that is affected by many factors such as animals, diet, incubation procedure, etc. (Weakley et al., 1983). According to Ventura et al. (2009) the high proportion of protein linked to the $\mathrm{ADF}$, which can reach half of total $\mathrm{CP}$, could explain the low degradability of CP. Several authors have also reported low total tract apparent CP digestibility (Abbeddou et al., 2011; Fondevila et al., 1994), suggesting a low small intestinal digestibility of rumen undegraded TP protein. Finally, the ruminal degradability of TP fibre is low because of the high NDF lignification and the presence of only a small fraction of soluble fibre in the peels. As a consequence, low values of NDF digestibility (36\%) have been reported (Gasa et al., 1989). Total phenols in TP can be another reason for the low nutritional values as they might affect negatively the palatability and apparent digestibility of feeds. However, some studies have showed that the inclusion of TP in the diet of sheep (Abbeddou et al., 2011) and beef cattle (Yuangklang et al., 2010) does not affect ruminal fermentation. Metabolizable energy content of TP can range between 8.6 and 9.0 MJ/kg DM (Abbeddou et al., 2011).

The use of TP in animal diets can reduce feeding costs for livestock farmers, and is an opportunity for the producing companies to avoid the cost of disposal (Barroso et al., 2006). Tomato pomace can be a valuable source of energy and nutrients for ruminants with lower price than conventional feed ingredients, but it should be properly preserved (Denek and Can, 2006). Due to storage difficulties, TP is frequently discarded, and therefore only a small volume of the annual production is used directly for feeding (without any treatment), and it is restricted to farms closely located to the processing plants (López-Parra et al., 2011).

\section{I.3.4. Effects of feeding tomato pomace to meat-producing ruminants}

Tomato pomace has been included in complete diets for growing lambs up to $20 \%$ of diet DM (Fondevila et al., 1994) or 48\% of DM in feed blocks (Ben Salem and 
Znaidi, 2008) with no negative effects on lambs performance. López-Parra et al. (2011) found that the inclusion of up to $15 \%$ of dried $\mathrm{TP}$ in the diet of fattening lambs replacing barley did not influence either the growth performance or the quality of the carcass and meat. Likewise, Fondevila et al. (1994) observed no differences by replacing barley grains and part of the soybeans in the diet of fattening lambs with TP. Porte et al. (1993) observed that the inclusion of TP up to $40 \%$ of the diet DM did not affect either the daily gain or the conversion rate of beef calves. Therefore, the use of dried TP could be profitable as long as its price was lower than that of barley or other cereals.

Feeding TP to ruminants can improve the quality of the meat because of the high content in both antioxidant compounds and FA beneficial for human health. Inclusion of TP in the diet of lambs has been reported to increase the intake of linoleic and $\alpha$ linolenic acids, and tended to increase the PUFA, PUFA n-6, $\alpha$-linolenic acid, linoleic acid, $\gamma$-tocopherol and retinol content in meat (Valenti et al., 2018). Both linoleic and $\alpha$ linolenic acids must be supplied in the diet, but they should be protected from ruminal biohydrogenation in order to increase their content in meat (Bessa et al., 2007). Feeding TP has also been reported to increase the meat quality of rabbits (Peiretti et al., 2013), increasing the proportion of PUFA in the meat FA, especially of linoleic and $\alpha$-linolenic acids, probably as a result of the greater intake. The increase in linoleic acid intake can modify the PUFA n-6/n-3 ratio to be less beneficial for human health (Wood et al., 2003), but some systematic reviews and meta-analysis have reported that the intake of linoleic acid is negatively related to the risk of coronary heart disease (Farvid et al., 2014). However, in ruminants, high levels of dietary PUFA may inhibit the activity of some rumen bacteria and the biohydrogenation process which favours the accumulation of C18:1 trans 10 instead of vaccenic acid as the major C18:1 trans isomer in the rumen and, consequently its content in milk and meat (Aldai et al., 2013). Moreover, C18:1 trans 10 is considered harmful for human health (Hodgson et al., 1996) and it cannot be converted into rumenic acid by the $\Delta 9$-desaturase (Griinari et al., 2000).

Dietary secondary compounds, such as phenols and tannins, can affect the FA composition of the meat through their effect on rumen lipid metabolism (Vasta and Luciano, 2011). Therefore, it cannot be excluded that the secondary compounds present in TP could affect the activity of rumen microorganisms. Valenti et al. (2018) reported a decrease in total odd and branched chain FA in meat when TP was fed to lambs, which 
have been suggested as potential biomarkers of duodenal flow of microbial biomass (Vlaeminck et al., 2015). Moreover, TP might have a positive effect on meat oxidative stability. Valenti et al. (2018) reported an increase in retinol content in the meat of lambs fed TP, which was attributed either to a higher intake of $\beta$-carotene, as it is the direct precursor of retinol in fat tissues (Álvarez et al., 2015), or to a higher intake of lycopene. Even though TP feeding increases the dietary intake of lycopene, an increase in lycopene has not been detected in the meat from pigs (Correia et al., 2017) or lambs (Valenti et al., 2018). In studies performed in mice, it has been reported that lycopene possesses partial pro-vitamin A activity, and thus contributes directly to the synthesis of retinol (Aydemir et al., 2016). Meat oxidative stability can be modified by the balance between oxidizable substrates (e.g., highly unsaturated PUFA) and antioxidant components, either of dietary origin, such as vitamins E and A, carotenoids and others, or endogenous (Bekhit et al., 2013). However, the differences in meat oxidative stability by feeding TP observed by Valenti et al. (2018) were low, although reached the significance level. In another study (Jiang et al., 2015a), lycopene inclusion in lamb diets at levels of $0.05,0.1$, or $0.2 \mathrm{~g} / \mathrm{kg}$ increased DM intake and average daily gain, and lamb meat tended to be darker and redder as indicated by lower lightness and hue angle values measured at $24 \mathrm{~h}$ after slaughtering. In addition, muscle fat content and lipid oxidation values decreased in the lycopene-supplemented groups, while PUFA concentrations increased compared to the control lambs (Jiang et al., 2015a). Lycopene dietary supplementation at $0.2 \mathrm{~g} / \mathrm{kg}$ also improved the antioxidant status of the lambs and optimizes the plasma lipid profile, by reducing the plasma concentrations of malondialdehyde, total cholesterol, total triglycerides, and low-density lipoprotein cholesterol, and increasing plasma concentrations of vitamin $\mathrm{E}$, total plasma antioxidant capacity and the activities of catalase, glutathione peroxidase and superoxide dismutase (Jiang et al., 2015b).

\section{I.3.5. Effects of feeding tomato pomace to dairy ruminants}

Several studies have investigated the effects of feeding TP to dairy cows and sheep. In a palatability test conducted with cows (Hoover and Dennison, 1957), it was observed that TP was as palatable as citrus pulp for cattle when was included up to $30 \%$ of the diet. Abbeddou et al. (2015) observed that the inclusion of TP in sheep diets up to $30 \%$, replacing the concentrate, increased milk fat content without affecting either milk production or protein content. Caluya et al. (2003) observed that TP could replace up to 
$50 \%$ of dietary forage due to its high fibre content, regardless of whether it was administered fresh, dried or as silage. Tomato pomace ensiled with $10 \%$ wheat straw can be a source of good quality forage for sheep (Denek and Can, 2006). However, feeding high amounts $(>1.5 \mathrm{~kg} / \mathrm{d})$ of fresh tomato fruits to adult goats has been reported to cause digestive disturbances (Ventura et al., 2009).

Feeding TP to dairy ewes has been reported to increase milk fat and PUFA content, especially that of linoleic acid and the isomers of linolenic acid, and increase the $n-3 / n-6$ FA ratio (Romano et al., 2010). However, other authors (Zhang et al., 2006) have reported no changes in milk composition of dairy ewes by feeding TP. A fraction of the linoleic and linolenic acids present in the TP can escape the ruminal biohydrogenation and be incorporated into milk fat in the mammary gland (Luna et al., 2008). Likewise, these FA can, to some extent, protect lipids from ruminal biohydrogenation (Ashes et al., 1992). Linoleic, $\alpha$-linolenic, and $\gamma$-linolenic acids are transformed to rumenic, trans vaccenic and vaccenic acids by ruminal microbiota (Mosley et al., 2002). Nevertheless, the rumenic acid can be further biohydrogenated to vaccenic acid and then to stearic acid, and both acids can be used for milk FA synthesis. On the other hand, $\alpha$-linolenic and $\gamma$-linolenic acids are hydrogenated to vaccenic acid, which enters the vaccenic acid pool in the mammary gland where is desatured by $\Delta 9$-desaturase to rumenic acid (Luna et al., 2008). These could help to explain the reported increases of CLA content in the milk from ruminants fed TP (Romano et al., 2010; Luna et al., 2008; Zhang et al., 2006). Romano et al. (2010) also observed that the milk produced by sheep fed diets with $20.4 \%$ of TP contained less cholesterol compared with the milk from sheep fed a control diet.

Antimethanogenic effects have been observed when tomato waste fruits and fresh tomato silage were included in the diet of dairy goats (Arco-Pérez et al., 2013; RomeroHuelva and Molina-Alcaide, 2013; Romero-Huelva et al., 2012). There is currently a great interest on the development of dietary strategies that could reduce methane emissions by ruminants (Martin et al., 2010), as methane is a greenhouse gas and represents an energy loss for the animal that can account up to $12 \%$ of the gross energy intake (Johnson and Johnson, 1995). Arco-Pérez et al. (2017) fed goats fresh tomato silage and observed a decrease of $15 \%$ in methane production per kilogram of DM ingested, whereas Romero-Huelva et al. (2012) reported a decrease of 39\% in methane emission when diets including feed blocks with tomato fruits were fed to dairy goats. 
The decrease in methane production might be the result of different processes: a decrease in the $\mathrm{OM}$ fermented in the rumen, diverting hydrogen away from methane production by using an alternative hydrogen sink, or inhibition of methanogenic activity and optimization of rumen fermentation (Ben Salem, 2010, Martin et al., 2010). The content of polyphenols or other secondary compounds in tomato by-products might act as natural antimethanogenic compounds. However, different compounds might have variable effects on methanogenesis, as it is speculated that there is a relation between the antimethanogenic effect of plant secondary compounds and their molecular weight together with chemical composition of diets (Vasta et al., 2009; Newbold et al., 2005). The reductions in methane production observed by Romero-Huelva et al. (2012) by feeding tomato waste fruits were accompanied by increased molar proportions of propionate, and the production of this volatile fatty acid (VFA) acts as an alternative hydrogen sink (McAllister and Newbold, 2008). Thus, pyruvate is reduced to propionate in a two-multistep pathway that results in less hydrogen production and hence decreased methane synthesis (Janssen, 2010). The relationships between the reduction in methane emissions and the abundance of methanogens reported in the literature are inconsistent. Moreover, it has been hypothesized that the composition of the Archaea community has a more important role in methane synthesis, rather than the abundance of methanogens (Morgavi et al., 2010). The antimethanogenic mechanisms of tomato ingredients remain yet unknown and deserve further research in the future (Arco-Pérez et al., 2017). In addition, to our best knowledge the possible influence of $\mathrm{TP}$ on rumen methane production has not yet been tested.

In summary, $\mathrm{TP}$ is a seasonal by-product with high-water content that needs to be preserved by drying or ensiling. Feeding ruminants TP is a feasible way to avoid the environmental contamination produced by this by-product, which is rich in protein and fat. However, more data on chemical composition and nutritive value of TP, especially of that produced in Spain, are needed to facilitate its use in ruminant feeding. Finally, the possible antimethanogenic effects of TP need to be assessed.

\section{I.4. Other by-products: citrus pulp and dried distillers grains with solubles}

There is a wide range of agroindustrial by-products that are produced in great amounts in Spain, but only citrus pulp and DDGS are reviewed here, as they were included in one diet used in the experiments of this Doctoral Thesis. 


\section{I.4.1. Citrus pulp}

The genus Citrus includes several important fruits (Kale and Adsule, 1995), being the most important on a worldwide basis sweet orange $(C$. sinensis $)$, tangerine $(C$. reticulate), lemon (C. limon), grapefruit ( $C$. paradisi) and minor citrus genuses that include sour orange (C. quarantium), shaddock (C.grandis), citron (C. medica) and lime (C. aurantifolia). According to FAO (2018), in 2017, Brazil, China and India were the greatest producers of oranges $(17,459,908,8,564,425$ and $7,647,000$ tons, respectively), China, Spain and Turkey were the greatest producers of tangerines and similar $(18,026,016,1,967,018$ and 1,550,469 tons), Mexico, China and India of lemons and limes $(2,528,174,2,364,000$ and 2,316,876 tons), and China, USA and Vietnam of grapefruit $(4,658,672,633,210$ and 568,352 tons $)$.

In 2017, Spain produced 3,357,163 tons of oranges, $1,967,018$ tons of mandarin, 923,192 tons of lemons and limes, and 78,752 tons of grapefruits, being the first producer of citrus fruits in the European Union and the sixth worldwide (MAPA, 2018. The main citrus producing areas in Spain are the Comunidad Valenciana, followed by Andalucía and Murcia. The Comunidad Valenciana is the main producer of oranges and tangerines, whereas Murcia is the main producer of lemons and grapefruit (MAPA 2018).

Citrus fruits are principally consumed as fresh fruit or as processed juice. After juice extraction, a residue composed of peels (flavedo and albedo), pulp (juice sac residue), rag (membranes and cores), and seeds is generated. This residue is the main source of citrus by-products that can be used for animal feeding (Ensminger et al., 1990; Sinclair, 1984). The main by-products from citrus processing are the fresh citrus pulp, which is the whole residue after juice extraction, representing between 49 and $69 \%$ of the fresh citrus fruit processed (as average, 60-65\% peels, 30-35\% pulp and $0-10 \%$ seeds; Martínez-Pascual and Fernández-Carmona, 1980), the dried citrus pulp (DCP) which is formed by shedding, liming, pressing and drying the peel, pulp and seed residues to reach about $8 \%$ moisture, and the citrus meal and fines, which is formed and separated during the drying process. Other citrus by-products are citrus molasses, citrus peel liquor, which is similar to citrus molasses, and citrus activated sludge, as well as the discarded citrus fruits (Madrid et al., 1996).

Citrus pulp, either fresh or dried, is considered a good substitute for cereals in 
ruminant diets due to its high energy content, which is similar to that of barley $(2.67$ Mcal of metabolizable energy $/ \mathrm{kg}$; De Blas et al., 2010). In addition, it has a high content of NDF $(20 \% \mathrm{DM})$ and pectines $(10 \% \mathrm{DM})$, that are highly fermented in the rumen. Citrus pulp is also a calcium-rich by-product (1-2\% DM), although its protein, fat and phosphorus content is low $(5-10,2 \%$ and $0.1 \%$ DM, respectively). The ash content is generally low (5\% DM), as well as ADL content (less than $1 \% \mathrm{DM})$, but the content in DCP vary with the processes used (De Blas et al., 2010) and fresh citrus pulp usually has lower calcium content compared to dried pulp (Heuzé et al., 2018; Calsamiglia et al., 2016). Fresh pulp is a more perishable product than DCP due to its greater water content, which makes fresh pulp more difficult to store and transport. The use of fresh citrus pulp is almost exclusive to ruminant animals, and is only justified in areas close to the production center due to the high cost of transportation (De Blas et al., 2010).

Citrus by-products have high digestibility of OM (80-85\%) and, unlike cereals whose energy intake is based on starch, the energy provided by citrus pulp is based on soluble carbohydrates and digestible fibre. The carbohydrates in citrus pulp are highly fermentable in the rumen, but they generate greater proportions of acetate and lower of lactate than the fermentation of starch (Wing, 1982), which decreases the risk of acidosis. Therefore, citrus pulp can be used, replacing the cereals, in ruminants fed high-concentrate diets to lower the risk of acidosis. On the other hand, citrus peels and seeds contain limonine that gives a bitter taste to the pulp, so that an excess in the diet can cause a decrease in the intake of animals during adaptation to this by-product. Therefore, levels of less than $20 \%$ citrus pulp in the diet and a progressive adaptation are recommended to prevent a reduction in feed intake and productive performance, since it has been observed that higher levels used in lambs can reduce palatability and productivity (Heuzé et al., 2018). In contrast, Bueno et al. (2002) replaced corn grain with up to $69.5 \%$ of DCP in the diet of Sannen kids and observed no negative effect on feed intake and daily gain, being the inclusion of $40 \%$ of DCP the level that resulted in the best performance of growing kids. Similarly, Martínez-Pascual and FernándezCarmona (1980) reported no negative effect on fattening lambs performance by feeding up to $30 \%$ of DCP.

Regarding milk production, López et al. (2014) replaced $61 \%$ of corn in a diet for lactating goats by DCP and observed no negative effect on milk yield, whereas fat milk content increased. The inclusion of citrus by-products in the diet might affect the FA 
profile of milk. For example, Ibáñez et al. (2017) included up to $60 \%$ of orange pulp in the diet of dairy goats, and reported an increase in the proportions of CLA trans 10 cis 12, linolenic acid, vaccenic acid, palmitic acid and heptadecanoic acid in the milk compared with a control diet, whereas the proportions of elaidic acid, linoleic acid and CLA cis 9 trans 11 plus trans 9 cis 11 decreased. However, the effects of including DCP in the diet of dairy small ruminants can be affected by the rest of feed ingredients, and more studies are needed to clarify the influence of DCP on the production, composition and FA profile of milk.

\section{I.4.2. Dried distillers grains with solubles}

Cereal grains can be used as seeds for future crops, as human and animal feeds and to produce biofuel. In 2017, more than 84 thousand tons of biofuel were produced in Spain (MAPA, 2019b). The cereals most used in the generation of biofuels are corn in the USA (excepting some States as Kansas, in which sorghum is the main cereal), wheat in Canada, and barley in the countries of Northern Europe. All these four cereals have been used in our country during the last years. In 2017, Spain produced 4,830,281, $5,785,944,3,775,645$ and 30,138 tons of wheat, barley, corn and sorghum, respectively, being the fifth largest producer of the EU with more than six thousand ha of cereal cultivation area (MAPA, 2019b). Most of the autumn-winter cereals are cultivated in dry land, whereas maize and sorghum are cultivated with irrigation systems. The main cereal regions are Castilla y León, Castilla la Mancha, Aragón and Andalucía (MAPA, 2019b).

The main by-product of the process of distillation of cereal grains in the biofuel industry are the DDGS, which are the whole grain without starch, which is removed during the fermentation process to obtain the ethanol. There are two processes to obtain ethanol from corn, either by wet or dry milling (Kim et al., 2008), and whereas both processes are similar generate different by-products. Basically, the production of ethanol requires a two-stage fermentation of starch. In the first stage, starch is decomposed into glucose and maltose, and in the second one there is a yeast fermentation that converts disaccharides and monosaccharides into ethanol. At the end, solid and liquid phases are generated. The liquid phase is evaporated and condensed into syrup, which is then mixed with the solid phase. The resulting decoction is centrifuged, dried and finally granulated (Pecka-Kielb et al., 2017). Different types of decoctions can be obtained depending on the technology used for ethanol production 
(Schingoethe, 2006), being the dried distillers grains and the DDGS the most important. The DDGS are the by-product most widely produced, and it is obtained from wet corn residues mixed with the condensed liquid phase and dried afterwards.

Corn DDGS have high-protein content, which can range from 28 to $36 \%$ of DM (De Blas et al., 2010). The DDGS protein is characterized by a low degradability in the rumen, resulting in high content of bypass protein (47-63\%) (Schingoethe, 2006). The presence of dead yeast cells improves the amino acid profile and taste of DDGS. The main source of energy in DDGS are fat and NDF. The fat content can range between 8.2 and $11.7 \%$ of DM, with unsaturated FA accounting for $80 \%$ of the total FA. The DDGS fat is rich in palmitic (13.5\%), linoleic (26.0\%), and linolenic (55.0\%) acids (PeckaKielb et al., 2017). The NDF content is also high (40-45\%), but the fibre is easily fermentable due to the low ADL content. However, because of the large fragmentation of the decoction, it cannot be considered as a source of physically effective NDF (Pecka-Kielb et al., 2017). In summary, corn DDGS are valuable feed ingredients, rich in protein and moderately high in fat and easily fermentable fibre, which can be used in the feeding of both ruminants and monogastrics (Heuzé et al., 2015).

DDGS are very palatable feeds, especially those which are fed fresh (national origin) to ruminants. However, theirs inclusion in the diet at high levels can affect negatively the fibrolytic activity in the rumen due to their high content of unsaturated fat (De Blas et al., 2010). In mixed diets, DDGS can replace much of concentrate feeds (such as soybean meal) and some cereal grains. One advantage of the use of DDGS as cereal replacers is that they tend to reduce the incidence and severity of acidosis, laminitis and fatty liver caused by an excess of fermentation of starch in the rumen (Heuzé et al., 2015), as energy in DDGS comes from fat and NDF.

Most studies analyzing the effects of including DDGS in the diet of dairy animals have been conducted in cows. Schingoethe et al. (2009) reviewed this topic and concluded that diets containing $20 \%$ of DDGS supported similar or greater milk production compared with those composed of traditional feeds, but with diets containing more than $30 \%$ of DDGS gut fill may limit DM intake. In addition, when feeding DDGS as forage replacers, an adequate effective fibre supply is needed to avoid milk fat depression. The inclusion of DDGS in the diet can also modify milk composition. Sasikala-Appukuttan et al. (2008) and Anderson et al. (2006) reported that 
including up to $20 \%$ of DDGS in the diet of dairy cattle increased the CLA concentration in milk, without having any negative effects on milk production. The effect of DDGS in the FA profile of milk can be result of the high fat content of the DDGS which might modify ruminal biohydrogenation. In another study, Kurokawa et al. (2012) reported that feeding DDGS to dairy cattle decreased milk protein content, but increased fat, lactose and total solids (TS) contents in milk as well as milk yield.

The number of studies conducted to assess the effects of feeding DDGS to small ruminants is limited. In sheep, the inclusion of $10-20 \%$ of DDGS in the diet had no negative effect on milk production but slightly decreased protein, TS and fat content (Wertz-Lutz et al., 2007). In goats, only Cais-Sokolińska et al. (2015) have evaluated the effect of feeding DDGS, but the study was focused on milk FA profile and fermentation process and aroma profile of the resulting kefir, and no information on milk yield, composition and quality is available. In this study, the inclusion of DDGS in the diet increased the PUFA content in the kefir produced from the milk of DDGS-fed goats (Cais-Sokolińska et al., 2015). Positive results were also observed when DDGS were fed to meat producing small ruminants. Thus, including corn DDGS in the diet of fattening lambs resulted in greater average daily gain and lower feeding costs per $\mathrm{kg}$ of gain compared to a conventional diet (Heuzé et al., 2015). In another study, the inclusion of $20 \%$ of DDGS replacing a rapeseed grain mixture did not adversely affect either the average daily gain or carcass characteristics of fattening lambs (McKeown et al., 2010). Finally, a decrease in methane production by feeding up to $30 \%$ of DDGS has been observed in dairy ewes and cows (Pecka-Kiełb et al., 2015; Benchaar et al., 2013), which has been related to the lower acetate/propionate ratio caused by the reduced fibre degradation as a consequence of the high fat content of DDGS.

In conclusion, DDGS are a good energy and protein source, that have shown positive results in dairy cows feeding, but no information on DDGS effects on the yield, composition and quality of goat's milk is available.

\section{I.5. Nutritional significance of acid detergent insoluble nitrogen fraction of feeds}

The fibrous fraction of feeds, which includes carbohydrates (mainly cellulose, hemicellulose and pectins) and other compounds such lignin, is considered to be the 
least digestible portion (Van Soest et al., 1991). However, ruminants can degrade the fibrous fraction of feeds more efficiently than monogastric animals, and pure hemicellulose and cellulose are completely degradable in the rumen. However, in laboratorial analysis, fibre is usually determined according to the content of hemicellulose, cellulose, lignin and other minor compounds. The most widely used fibre analysis in the field of ruminant nutrition is the Van Soest detergent system (Van Soest et al., 1991; Van Soest, 1966), which not only quantifies the amount of cell wall (NDF analysis), but also measures the amounts of hemicellulose, cellulose and lignin (Van Soest and McQueen, 1973). The proportion of cell wall is measured as NDF after treating the feed with neutral detergent solution, although this fraction does not include the pectins that are soluble in neutral detergent solution. The ADF fraction is obtained after treating the feed with acid detergent solution, and it includes lignin, cellulose, silica and insoluble forms of $\mathrm{N}$, but not hemicellulose. Therefore, when both analyses are performed sequentially, the content of hemicelluloses can be calculated by difference. Because pectins are soluble in neutral detergent solution but insoluble in acid detergent solution, the pectin fraction of feeds can be determined by difference after performing the ADF analysis both directly and sequentially after NDF analysis.

During laboratory analysis, ADF fraction is the residue remaining after boiling a feed sample for $1 \mathrm{~h}$ in acid detergent solution, which consists of sulfuric acid and cetyltrimethylammonium bromide (CTAB). The ADIN fraction is the $\mathrm{N}$ content of the ADF residue, i.e. the amount of $\mathrm{N}$ that is insoluble in acid detergent solution (Firkins et al., 1984), and therefore a positive relation between ADF and ADIN might exist. However, Machacek and Kononoff (2009) reported a poor relationship between these two variables. In forages, the ADIN content has been closely related to $\mathrm{N}$ digestibility, as higher contents of ADIN turned into lower forage digestibility ( $\mathrm{Yu}$ and Thomas, 1976; Goering et al., 1972; Van Soest, 1965). On the other hand, poor relationships between ADIN content and $\mathrm{N}$ indigestibility have been reported for non-forage plant protein sources that have been heat treated (Weiss et al., 1989; Nakamura et al., 1994). However, the ADIN analysis is widely accepted as a good measure of heat damage in forages (NRC, 2001; Goering et al., 1972).

In ruminant nutrition, the use of protein sources with low ruminal degradation increases the feed protein reaching the small intestine and can reduce $\mathrm{N}$ excretion to the environment, and it is important to make accurate estimations of both rumen 
degradability and total tract digestibility of CP. Some feeding systems for ruminants use the ADIN analysis as a measure of $\mathrm{N}$ availability for the host animal. For example, the UK Metabolizable Protein System (Webster, 1987) assumes that the ADIN fraction is both undegradable in the rumen and indigestible in the small intestine, and therefore the amount of digestible rumen undegraded protein in a feed is predicted from its ADIN content. The Cornell Net Carbohydrate and Protein System also assumes that the ADIN fraction is undegradable, and it contains heat-damaged proteins (i.e. Maillard reaction products) and the proteins associated with lignin and tannins (Sniffen et al., 1992).

Several authors reported that total tract $\mathrm{N}$ digestibility decreases when concentration of ADIN in the feeds increases (Van Soest, 1994; Weiss et al., 1986; Thomas et al., 1982; Yu and Thomas, 1976). However, all these results were reported for forages, whereas in other feeds the relationship between ADIN and N digestibility is not clear. Nakamura et al. (1994) reported that ADIN was digestible to some extent (up to $58 \%$ ) in heat-damaged corn gluten meal and DDGS, which suggest that suppositions about ADIN indigestibility are not totally accurate. Machacek and Kononoff (2009) stated that ADIN might not be a good indicator of unavailable protein, however a negative relationship between ADIN content and total tract $\mathrm{N}$ digestibility exists and it might differ from the one-to-one negative relationship reported in forages. In the study of Nakamura et al. (1994) the ADIN absorbed could not be used by growth lambs and cattle, and the NRC (2001) suggests that ADIN could be a useful indicator of nonusable $\mathrm{N}$ but may not be useful for estimating the digestibility of the rumen undegradable protein.

Reported levels of ADIN is feeds range from $0.4 \%$ of total $\mathrm{N}$ in corn gluten feed and cottonseed meal to $31 \%$ of total $\mathrm{N}$ for DDGS, forages and some concentrates, either wet or dried (Vargas-Bello-Perez et al., 2008; Kleinschmit et al., 2007; NRC, 2001; Edionwe and Owen, 1989; Weiss et al., 1989; Clark et al., 1987; Pena et al., 1986), but the proportion can be even greater in heat-damaged feeds (NRC, 2001). Heat damage might cause the creation of Maillard products that are formed during the thermal processing of feed ingredients and/or diets. These compounds result from the covalent bond formed between a free reactive $\mathrm{NH}_{2}$ group of an amino acid and the carbonyl group of a reducing sugar (Friedman, 1996), and they are indigestible (Broderick et al., 2000). The formation of Maillard compounds might be quite common in agroindustrial by-products, as they go through many processes involving heat and moisture treatment. 
For example, traditional methods for tomato peeling utilize hot lye or steam processes (Lu et al., 2019) and in the olive oil industry, heat is used to remove the solvents used during the second oil extraction of OC to obtain olive pomace oil. Therefore, agroindustrial by-products may have high ADIN contents. For example, Molina-Alcaide and Yáñez-Ruiz (2008) reported that ADIN content can reach up to a $70 \%$ of total $\mathrm{N}$ in OC samples, and high ADIN (16-26\% of total N) values have also been reported to TP (Rahbarpour et al., 2012; Weiss et al., 1997; Fondevila et al., 1994). The ADIN analysis would be of special interest in agroindustrial by-products to evaluate their $\mathrm{N}$ availability, as many of them are originated in processes involving heating. Nevertheless, the use of ADIN to accurately determine $\mathrm{N}$ digestibility requires further investigation, as there is no consensus regarding that topic.

In addition, several studies (Vanegas et al., 2016; Guevara-González et al., 2015; Arroyo and González, 2013) have reported that ADIN degradation in the rumen was greater than that observed for the neutral detergent insoluble N (NDIN) fraction. Thus, Vanegas et al. (2016) observed lower ${ }^{15} \mathrm{~N}$ abundance in the ADIN than in total $\mathrm{N}$ and the NDIN of three different feeds, which was attributed to a $\mathrm{N}$ contamination of the ADF residue with $\mathrm{CTAB}$, a N-containing reagent used in the ADF analysis. However, this hypothesis needs to be confirmed, as it would imply an overestimation of ADIN content in feeds.

\section{I.6. Objectives and working hypothesis}

The general objective of this Doctoral Thesis is to obtain information on chemical composition and nutritional value for small ruminants of two agroindustrial by-products produced in high amounts in Spain: olive cake (OC) and tomato pomace (TP). Our hypothesis was that processing would influence both chemical composition and nutritional value of these by-products, and therefore several factors related to processing are evaluated. In addition, it was hypothesized that the inclusion of agricultural byproducts in the diet of dairy goats would improve the yield and quality of the milk. The general objective was divided in the following partial objectives:

The first objective was to assess the influence of several factors (storage time, processing and particle size) on chemical composition and in vitro ruminal fermentation of OC samples obtained at different Spanish extraction plants. In addition, the possibility to estimate the in vitro ruminal degradation of OC from chemical 
composition was assessed. This was the objective of the first and second papers (Experiments 1 and 2) entitled "Influence of storage time and processing on chemical composition and in vitro ruminal fermentation of olive cake" and "Variability in the chemical composition and in vitro ruminal fermentation of olive cake by-products" and a fifth paper (Experiment 3) which is included in the Appendix.

The second objective was to analyze the variability in the nutritive value of TP samples collected from two processing plants during the tomato campaign and to assess the effects of including increasing doses of TP in a diet for fattening lambs on in vitro fermentation and methane production. This objective was addressed in the third paper (Experiment 4) entitled "Nutritive value of tomato pomace for ruminants and its influence on in vitro methane production".

The third objective was to assess the effects of replacing conventional ingredients in the diet of dairy goats with a mixture of by-products (DDGS, DCP and EOC) on feed intake and nutrient digestibility, milk yield and composition, urinary excretion of PD and methane emissions. This objective was addressed in the sixth paper (Experiment 5) titled "Effects of including a mixture of agroindustrial by-products in the diet of dairy goats on nutrients utilization, ruminal fermentation, methane production and milk yield and composition", that is included in the Appendix.

The fourth objective was to verify the lower ${ }^{15} \mathrm{~N}$ abundance in the ADIN fraction compared with both total $\mathrm{N}$ and NDIN fractions, and to assess the possible ADIN contamination and the factors influencing it. This was the objective of the fourth paper (Experiment 6) entitled "The acid detergent insoluble nitrogen (ADIN) analysis overestimates the amount of $\mathrm{N}$ associated to acid detergent fibre". 
Chapter II. METHODOLOGY 


\section{II.1. Animals and feeding}

Four adult rumen-fistulated Lacaune sheep $(63.5 \pm 2.05 \mathrm{~kg}$ of body weight $(\mathrm{BW}))$ were used as donors of ruminal fluid for the in vitro Experiments (1, 2, 3 and 4) and to conduct the in situ incubations (Experiment 4). Sheep were individually housed and had free access to fresh water over the trials. Animals were fed twice daily (8:00 and 18:00) a 2:1 grass hay:concentrate diet at a rate of $45 \mathrm{~g} \mathrm{DM} / \mathrm{kg} \mathrm{BW}^{0.75}$. The diet contained 114, 365, and $160 \mathrm{~g}$ of CP, NDF, and ADF per kg DM, respectively, and was formulated to meet maintenance requirements of the experimental animals (NRC, 2007). Sheep were managed in accordance with the Spanish guidelines for experimental animal protection (Royal Decree 53/2013 of 1 st February on the protection of animals used for experimentation or other scientific purposes) and all experimental procedures were approved by the Institutional Animal Care and Use Committee of the Comunidad Autónoma de Madrid (PROEX 035/17).

For the in vivo study described in the Appendix (Experiment 5; Paper 6), twelve Murciano-Granadina dairy goats producing $1642 \pm 157.7 \mathrm{~kg}$ milk/day, with $50.8 \pm 1.85$ $\mathrm{kg}$ of $\mathrm{BW}$, and $9.8 \pm 1.17$ days in milk were divided into two homogeneous groups based on BW and milk yield at the beginning of the Experiment. Goats were placed in individual boxes with free access to fresh water, and each group was randomly assigned to one of the two experimental diets. Animals were handled in accordance with the Spanish guidelines for experimental animal protection, and all experimental procedures were approved by the Ethic Committee for Animal Experimentation of the Spanish Research Council and the Junta de Andalucía (approval number 29/08/2016/145).

Two diets were formulated to meet the $\mathrm{N}$ and energy requirements of MurcianoGranadina goats producing daily 2 kg of milk (Aguilera et al., 1990; Prieto et al., 1990). The control diet (CON) was based on alfalfa hay and a high-cereal concentrate in a 50:50 ratio. The experimental (BYP) diet was also based on a 50:50 ratio alfalfa hay and concentrate, in which $44 \%$ of conventional ingredients (corn, barley, soybean meal, palmiste meal and wheat bran) was replaced with a mixture of 180, 180 and $80 \mathrm{~g}$ of corn DDGS, DCP and EOC per kg concentrate, respectively (fresh matter basis). Diets were supplied twice a day at 09:00 and 16:00 over the trial. The ingredients of both concentrates, and chemical composition and FA profile of feeds of both diets is shown in Table 1. 
Table 1. Ingredient and chemical composition of the experimental concentrates fed to dairy goats and potential use as human food of concentrate ingredients.

\begin{tabular}{|c|c|c|}
\hline \multirow[t]{2}{*}{ Item } & \multicolumn{2}{|c|}{ Concentrate } \\
\hline & $\mathrm{CON}$ & BYP \\
\hline \multicolumn{3}{|l|}{ Ingredients, $\mathrm{g} / \mathrm{kg}$ as fed } \\
\hline Corn & 330 & 268 \\
\hline Barley & 200 & - \\
\hline Wheat & 100 & 100 \\
\hline Soybean meal & 122 & 102 \\
\hline Palm meal & 88 & - \\
\hline Colza meal & 25 & 25 \\
\hline Wheat bran & 100 & 30 \\
\hline Corn DDGS & - & 180 \\
\hline Dry citrus pulp & - & 180 \\
\hline Exhausted olive cake & - & 80 \\
\hline Calcium soap & 12.0 & 12.0 \\
\hline $\mathrm{CaCO}_{3}$ & 10.0 & 10.0 \\
\hline $\mathrm{NaHCO}_{3}$ & 8.0 & 8.0 \\
\hline $\mathrm{NaCl}$ & 3.0 & 3.0 \\
\hline Vitamin-mineral mixture & 2.0 & 2.0 \\
\hline \multicolumn{3}{|l|}{ Chemical composition, $\mathrm{g} / \mathrm{kg}$ as fed basis } \\
\hline Dry matter & 894 & 883 \\
\hline Organic matter & 843 & 824 \\
\hline Crude protein & 160 & 174 \\
\hline Neutral detergent fibre & 205 & 208 \\
\hline Acid detergent fibre & 75.9 & 85.7 \\
\hline Acid detergent lignin & 17.4 & 23.4 \\
\hline Ether extract & 28.2 & 47.0 \\
\hline Total soluble polyphenols & 1.95 & 6.05 \\
\hline \multicolumn{3}{|l|}{ Fatty acids, $g / 100 \mathrm{~g}$ total fatty acids } \\
\hline $\mathrm{C} 12: 0$ & 7.01 & 0.282 \\
\hline $\mathrm{C} 14: 0$ & 2.78 & 0.371 \\
\hline $\mathrm{C} 14: 1$ cis 9 & $\mathrm{ND}^{1}$ & 0.001 \\
\hline C16:0 & 21.6 & 20.6 \\
\hline C16:1 cis 9 & 0.169 & 0.001 \\
\hline C18:0 & 2.78 & 2.76 \\
\hline C18:1 trans 9 & 0.077 & 0.004 \\
\hline C18:1 trans 11 & 0.080 & 0.002 \\
\hline C18:1 cis 9 & 26.6 & 34.5 \\
\hline $\mathrm{C} 18: 1$ cis 11 & 0.828 & 0.875 \\
\hline $\mathrm{C} 18: 2$ trans 9, trans 12 & 0.004 & 0.009 \\
\hline $\mathrm{C} 18: 2$ cis 9 , cis 12 & 34.1 & 36.7 \\
\hline C20:0 & 0.343 & 0.427 \\
\hline Potential use of ingredients as human food $(\%)^{2}$ & 64.4 & 38.7 \\
\hline
\end{tabular}

${ }^{1}$ ND: not detected.

${ }^{2}$ Calculated according to Wilkinson (2011) 
II.2. By-products, feeds and diets

For the first and second Experiments (Papers 1 and 2), a total of 42 samples of OC representative of those available in Spain for animal feeding were obtained at nine different extraction plants located in the South of Spain during the 2015/16 and 2016/17 olive oil campaigns (Table 2). Samples were classified according to processing type (COC, EOC and cyclone OC (CYOC)), and storage time in the open-air ponds (from one to 14 months). Twenty-five samples of COC were obtained by drying the "alperujo" and all of them were pelleted, whereas nine EOC samples were generated by subjecting the dried "alperujo" to oil extraction using hexane and drying the exhausted cake, and eight CYOC samples came from the particles collected from the air in cyclone decanters during the "alperujo" drying process. Processing of all OC samples were performed at the extraction plants using the habitual procedures in each of them. Storage time of the "alperujo" in the ponds was three months or lower for 10 samples (four COC, three EOC and three CYOC), between four and six months for 16 samples (11 COC, three EOC and two CYOC), and seven months or longer for 16 samples (10 COC, two EOC and four CYOC. All samples were ground to pass a $1 \mathrm{~mm}$ screen before chemical analyses and in vitro incubations.

Twenty-one samples from the batch of OC samples described above were used independently (Experiment 1; Paper 1) conducted to assess the influence of storage time on chemical composition and in vitro ruminal fermentation of COC, EOC and CYOC samples. The samples used are described as follows: six COC (AC1 to AC6) and six EOC (AE1 to AE6) samples obtained at monthly intervals from a single pond (A) from December (one month storage time) to May (six month storage time). The rest of the samples were obtained from a different pond (B) at monthly intervals from May (six months storage) to July (eight months storage). Samples were either COC (BC6 to BC8), EOC (BE6 to BE8) or CYOC (BCY6 to BCY8). All samples were ground (1 mm screen) before analysis of chemical composition and in vitro incubations.

In the third experiment (Paper 5; Appendix), four samples of COC from the same trommel at different stages of the screening process with different particle size were studied. The samples used are described as follow: bigger than 3 (COC3), 2 (COC2) and $1 \mathrm{~mm}(\mathrm{COC} 1)$, or smaller than $1 \mathrm{~mm}$ (COC0). Additionally, alfalfa hay and barley straw samples were used with comparative purposes. 
Table 2. Samples of olive cake (OC) used in this Thesis representative of those available in Spain for animal feeding were obtained at nine different extraction plants.

\begin{tabular}{|c|c|c|c|}
\hline Sample & "Orujera" & Storage time (months) & OC Type \\
\hline AE1 & Puente Genil & 1 & Exhausted OC \\
\hline AE2 & Puente Genil & 2 & Exhausted OC \\
\hline AE3 & Puente Genil & 3 & Exhausted OC \\
\hline AE4 & Puente Genil & 4 & Exhausted OC \\
\hline AE5 & Puente Genil & 5 & Exhausted OC \\
\hline AE6 & Puente Genil & 6 & Exhausted OC \\
\hline $\mathrm{AC} 1$ & Puente Genil & 1 & Crude OC \\
\hline $\mathrm{AC} 2$ & Puente Genil & 2 & Crude OC \\
\hline AC3 & Puente Genil & 3 & Crude OC \\
\hline $\mathrm{AC} 4$ & Puente Genil & 4 & Crude OC \\
\hline AC5 & Puente Genil & 5 & Crude OC \\
\hline AC6 & Puente Genil & 6 & Crude OC \\
\hline BC6 & Puente Genil & 6 & Crude OC \\
\hline BC7 & Puente Genil & 7 & Crude OC \\
\hline $\mathrm{BC} 8$ & Puente Genil & 8 & Crude OC \\
\hline BCY6 & Puente Genil & 6 & Cyclone OC \\
\hline BCY7 & Puente Genil & 7 & Cyclone OC \\
\hline BCY8 & Puente Genil & 8 & Cyclone OC \\
\hline BE6 & Puente Genil & 6 & Exhausted OC \\
\hline BE7 & Puente Genil & 7 & Exhausted OC \\
\hline BE8 & Puente Genil & 8 & Exhausted OC \\
\hline CC112 & Puente Genil & 12 & Crude OC \\
\hline $\mathrm{CC} 212$ & Puente Genil & 12 & Crude OC \\
\hline CC312 & Puente Genil & 12 & Crude OC \\
\hline DC6 & Linares & 6 & Crude OC \\
\hline DCY6 & Linares & 6 & Cyclone OC \\
\hline DC7 & Linares & 7 & Crude OC \\
\hline DCY7 & Linares & 7 & Cyclone OC \\
\hline $\mathrm{CC7}$ & Puente Genil & 7 & Crude OC \\
\hline $\mathrm{CC} 8$ & Puente Genil & 8 & Crude OC \\
\hline DC6 & Palenciana & 6 & Crude OC \\
\hline EC6 & Marchena & 6 & Crude OC \\
\hline FC6 & Baena & 6 & Crude OC \\
\hline GC6 & Bogarre & 6 & Crude OC \\
\hline HC6 & Cabra & 6 & Crude OC \\
\hline IC6 & Pedro Abad & 6 & Crude OC \\
\hline DC8 & Palenciana & 8 & Crude OC \\
\hline DCY8 & Palenciana & 8 & Cyclone OC \\
\hline ECY11 & Marchena & 1 & Cyclone OC \\
\hline EC11 & Marchena & 1 & Crude OC \\
\hline $\mathrm{EC} 21$ & Marchena & 1 & Crude OC \\
\hline ECY21 & Marchena & 1 & Cyclone OC \\
\hline
\end{tabular}


In the fourth Experiment (Paper 3), 12 samples of TP were obtained from two of the biggest Spanish tomato processing plants (Tomates del Guadiana Soc. Coop., Badajoz, Spain, and PRONAT, Badajoz, Spain) during the 2016 tomato harvesting campaign. The tomato campaign in Spain is usually concentrated in August and September. Samples (4-5 kg) were obtained weekly at each plant on the 12th, 19th, and 26th August and the 2nd, 9th, and 16th of September, frozen $\left(-20^{\circ} \mathrm{C}\right)$ and lyophilized. In all cases, samples were the final tomato-processing disposal. All samples were ground at $2 \mathrm{~mm}$, and subsamples were ground at $1 \mathrm{~mm}$ before chemical analyses and in vitro incubations.

Additionally, in this Experiment, four diets were used to analyze the effects of including increasing amounts of dried TP in a high-concentrate diet for fattening lambs. A control diet and three experimental diets were formulated by replacing different amounts of barley straw, soybean meal, and wheat bran in the control diet with 60,120 , or $180 \mathrm{~g}$ per $\mathrm{kg}$ (fresh matter basis) of a dried TP sample. A composited sample of the 12 TP samples analysed previously was used, and it contained 967, 163, 572, 446, and $95.2 \mathrm{~g}$ of $\mathrm{OM}, \mathrm{CP}, \mathrm{NDF}, \mathrm{ADF}$ and $\mathrm{EE}$ per $\mathrm{kg} \mathrm{DM}$, respectively. All diets were formulated to have similar $\mathrm{CP}$ and NDF content to the control diet and therefore TP replaced fibrous (barley straw and wheat bran) and protein (soybean meal) conventional ingredients. The ingredients and chemical compositions of the four experimental diets are given in Table 3. Subsamples of the diets were ground at $1 \mathrm{~mm}$ before in vitro incubations.

Eighteen corn and 22 sunflower (SF) ${ }^{15} \mathrm{~N}$-enriched samples were used in the sixth Experiment (Paper 4), which was conducted to verify the lower ${ }^{15} \mathrm{~N}$ abundance in ADIN compared with both total $\mathrm{N}$ and NDIN, and to assess the possible ADIN contamination and the factors influencing it. Samples were obtained from previous agricultural experiments aimed at measuring the effects of nitrification inhibitors on $\mathrm{N}_{2} \mathrm{O}$ losses in different crops, and the results have been reported by Guardia et al. (2018). Briefly, corn (Zea mays L. FAO class 600) samples were obtained in 2015 from six microplots $(1 \times 1 \mathrm{~m}$; three microplots/treatment $)$ which received either ${ }^{15} \mathrm{NH}_{4} \mathrm{NO}_{3}$ $\left({ }^{15} \mathrm{NAM}\right)$ or $\mathrm{NH}_{4}{ }^{15} \mathrm{NO}_{3}\left({ }^{15} \mathrm{NIT}\right)$; both 98 atom $\%{ }^{15} \mathrm{~N}$; Campro Scientific $\mathrm{GmbH}$, Berlin, Germany) to be labelled. Both ${ }^{15}$ NAM and ${ }^{15}$ NIT were applied as a top-dressing at a rate of $90 \mathrm{~kg}$ total N/ha. At harvest, plants were cut by hand at the soil level, and then the aerial biomass (stem, leaves and cob) was separated from grain. In addition, roots 
situated in the middle of each microplot were sampled and washed with water to separate roots from soil. In total, there were 18 corn samples (six microplots (three ${ }^{15} \mathrm{NAM}$ and three $\left.{ }^{15} \mathrm{NIT}\right) \times$ three plant fractions).

Table 3. Ingredients and chemical composition of experimental diets containing increased amounts of tomato pomace (TP).

\begin{tabular}{lcccc}
\hline Item & Control & TP6 & TP12 & TP18 \\
\hline Ingredient (g/ kg fresh matter) & & & & \\
Barley & 315 & 315 & 315 & 315 \\
Corn & 252 & 275 & 284 & 285 \\
Wheat & 130 & 130 & 130 & 130 \\
Barley straw & 120 & 85.0 & 35.0 & 20.0 \\
Soybean meal 46\% & 110 & 96.0 & 66.0 & 60.0 \\
Wheat bran & 48.1 & 20.0 & 40.0 & - \\
Tomato pomace & - & 60.0 & 120 & 180 \\
Calcium soap & 15.0 & 15.0 & - & - \\
Calcium carbonate & 5.0 & 5.0 & 5.0 & 5.0 \\
Mineral/vitamin premix & 5.0 & 5.0 & 5.0 & 5.0 \\
Chemical composition ${ }^{1}$ & & & & \\
Dry matter & 903 & 903 & 902 & 905 \\
Organic matter $_{\text {Crude protein }}$ & 945 & 957 & 969 & 970 \\
Neutral detergent fibre $_{\text {Acid detergent fibre }}$ & 145 & 145 & 145 & 145 \\
Ether extract $_{\text {Non structural carbohydrates }}$ & 245 & 242 & 245 & 250 \\
\hline Calculated from analysed & 100 & 107 & 111 & 126 \\
\hline
\end{tabular}

${ }^{1}$ Calculated from analysed composition of individual feed ingredients. All chemical fractions are expressed as $\mathrm{g} / \mathrm{kg}$ dry matter, excepting dry matter ( $\mathrm{g} / \mathrm{kg}$ fresh matter). Non-structural carbohydrates were calculated by difference (organic matter - crude protein - neutral detergent fibre - ether extract).

Sunflower (Helianthus annuus L., P64LL62 hybrid Pioneer) samples were obtained in 2016 using two different schemas of ${ }^{15} \mathrm{~N}$ fertilization: either the residual ${ }^{15} \mathrm{~N}$ from the previous corn crops (SF1) or by applying either ${ }^{15}$ NAM or ${ }^{15}$ NIT (both 10 atom $\%{ }^{15} \mathrm{~N}$; Campro Scientific $\mathrm{GmbH}$, Berlin, Germany) as a top-dressing at a rate of $68 \mathrm{~kg}$ total $\mathrm{N} /$ ha to parcels which had not been previously ${ }^{15} \mathrm{~N}$-fertilized (SF2). Sunflower plants were cut as previously described and seeds were separated from the aerial biomass (stem+leaves+flower capitula or head). Unfortunately, one replicate for 
${ }^{15}$ NAM-SF2 treatment was lost, and therefore a total of 22 SF samples were available.

\section{II.3. In vitro incubations: measurement of gas production kinetics}

For the determination of gas productions kinetics of samples of OC, TP and diets containing TP, four replicates per sample were obtained by using the ruminal fluid from each of the four rumen-fistulated sheep as inoculum. Ruminal contents of each sheep were obtained before the morning feeding, strained through four layers of cheesecloth into previously warmed thermal flasks, and immediately transported to the laboratory. The fluid of each sheep was independently mixed with pre-warmed $\left(39^{\circ} \mathrm{C}\right)$ culture medium (Goering and Van Soest, 1970; without trypticase) in a proportion 1:4 under $\mathrm{CO}_{2}$ flushing. The medium of Goering and Van Soest (1970) was modified by replacing the $\left(\mathrm{NH}_{4}\right) \mathrm{HCO}_{3}$ with $\mathrm{NaHCO}_{3}$ and excluding the trypticase to avoid $\mathrm{N}$ supply. Samples (200 $\mathrm{mg}$ of DM) of each feed were accurately weighed into $60 \mathrm{ml}$ vials. Vials were filled up with $20 \mathrm{ml}$ of the rumen fluid-culture medium mixture using a WatsonMarlow 520UIP31 peristaltic pump (Watson-Marlow Fluid Technology Group, Cornwall, UK), sealed with rubber stoppers, and incubated at $39{ }^{\circ} \mathrm{C}$ for $120 \mathrm{~h}$. Gas production was measured at 3, 6, 9, 12, 15, 22, 26, 31, 36, 48, 58, 72, 96 and $120 \mathrm{~h}$ using a pressure transducer (Delta Ohm DTP704-2BGI, Herter Instruments S.L, Barcelona, Spain) and a plastic syringe and the gas produced at each sampling time was released to prevent gas accumulation. Two blanks (vials without sample) per inoculum were also incubated to correct gas production values for endogenous production.

The potential in vitro DM degradability (DMD120) was determined by weighing $300 \mathrm{mg}$ of each sample (three bags per sample) into polyester bags of $30 \mu \mathrm{m}$ pore size (Ankom Corp \#57, Ankom Technology Corp., Fairport, NY, USA) and incubating the bags in a 1:4 mixture of ruminal fluid and the incubation medium of Goering and Van Soest (1970) in an Ankom Daisy II incubator at $39^{\circ} \mathrm{C}$ under continuous rotation for 120 h. A mixture of equal parts of the ruminal fluid from each sheep was used as inoculum. After $120 \mathrm{~h}$, bags were washed with cold water, dried at $60^{\circ} \mathrm{C}$ for $48 \mathrm{~h}$, and weighed to calculate DMD120.

The in vitro NDF and DM degradability (NDFD and DMD, respectively) in the first Experiment (Paper 1) were determined by weighing $300 \mathrm{mg}$ of OC samples in polyester bags (30 $\mu \mathrm{m}$ pore size; Ankom Corp \#57, Ankom Technology Corp., Fairport, NY, USA), which were incubated with buffered ruminal fluid in an Ankom Daisy II 
incubator (Ankom Technology Corp., Fairport, NY, USA) at $39^{\circ} \mathrm{C}$ under continuous rotation. Ruminal fluid was obtained from each sheep as described before and equally mixed before conducting the incubations. After $48 \mathrm{~h}$, bags were washed with cold water, dried at $60{ }^{\circ} \mathrm{C}$ for $48 \mathrm{~h}$ and weighed to calculate the DMD. Bags were then extracted with boiling neutral detergent solution (Van Soest et al., 1991) for $1 \mathrm{~h}$ using an Ankom 220 Fibre Analyser unit (Ankom Technology Corp., Fairport, NY, USA), dried at $60^{\circ} \mathrm{C}$ for $48 \mathrm{~h}$ and weighed to calculate the NDFD.

\section{II.4. In vitro incubations: measurement of fermentation parameters}

Samples of OC, TP and diets including TP were fermented in vitro for $24 \mathrm{~h}$ using the methodology described before to determine the main fermentation parameters, with some modifications in the study with TP samples. Gas production was measured, vials were then uncapped, their content was homogenized and the $\mathrm{pH}$ was measured using a Crison Basic $20 \mathrm{pH}$ meter (Crison Instruments, Barcelona, Spain). For determining VFA and $\mathrm{NH}_{3}-\mathrm{N}$ concentrations, $3 \mathrm{ml}$ of the content of each vial was mixed with $3 \mathrm{ml}$ of $\mathrm{HCl} 0.5 \mathrm{~N}$, and samples were stored at $-20{ }^{\circ} \mathrm{C}$ until analyses. Vials were then uncapped, their content was homogenized, the $\mathrm{pH}$ was immediately measured (Crison Basic $20 \mathrm{pH}-$ meter, Crisson Instruments, Barcelona, Spain), and $3 \mathrm{ml}$ of the vials' contents were mixed with $3 \mathrm{ml}$ of $0.5 \mathrm{M} \mathrm{HCl}$. Samples were frozen $\left(-20{ }^{\circ} \mathrm{C}\right)$ until VFA and $\mathrm{NH}_{3}-\mathrm{N}$ analyses.

In the study with TP (Experiment 4; Paper 3) samples, the amount of sample was increased to get enough gas for the analysis of methane concentration; therefore, 400 $\mathrm{mg}$ of each diet was fermented with $40 \mathrm{~m}$ - of the ruminal fluid and culture medium mixture in $120 \mathrm{ml}$ vials. Gas production was measured and a gas sample $(10 \mathrm{ml})$ was stored in an evacuated tube (Terumo Europe N.V., Leuven, Belgium) for analysis of methane concentration. Additionally, after $8 \mathrm{~h}$ of incubation, gas production was measured and the gas was sampled for methane analyses as described. Immediately, 1 $\mathrm{ml}$ of each vial content was taken using an insulin syringe, mixed with $1 \mathrm{~mL}$ of $0.5 \mathrm{M}$ $\mathrm{HCl}$, and stored at $-20{ }^{\circ} \mathrm{C}$ for $\mathrm{VFA}$ and $\mathrm{NH}_{3}-\mathrm{N}$ analyses. After $24 \mathrm{~h}$, the gas produced and the $\mathrm{pH}$ of the vials' contents were measured and samples for methane, VFA and $\mathrm{NH}_{3}-\mathrm{N}$ analyses were taken as before described. 


\section{II.5. In vitro intestinal digestibility}

The determination of the in vitro intestinal digestibility of protein (IDCP) in the fourth Experiment with TP samples followed the three-step procedure described by Gargallo et al. (2006) and was performed as detailed by Belverdy et al. (2019). Briefly, $3 \mathrm{~g}$ of each TP sample ( $2 \mathrm{~mm}$ size) was weighed into nylon bags $(7 \times 14 \mathrm{~cm} ; 46 \mu \mathrm{m}$ pore size) and incubated in the rumen of each sheep immediately before the afternoon feeding on two different days. After $16 \mathrm{~h}$ of in situ incubation, bags were washed, frozen $\left(-20^{\circ} \mathrm{C}, 48 \mathrm{~h}\right)$ to facilitate the detachment of particle-associated bacteria, thawed, washed three times with cold water ( $5 \mathrm{~min}$ each) in a turbine washing machine, frozen again $\left(-20^{\circ} \mathrm{C}\right)$, lyophilized, and weighed. Finally, bag residues were analysed for $\mathrm{N}$ content to calculate the in situ degradability of CP. Bag residues were pooled by TP sample and sheep and $0.5 \mathrm{~g}$ of each were weighed in duplicate into nylon bags $(5 \times 5 \mathrm{~cm}$; $46 \mu \mathrm{m}$ pore size). Bags were incubated into an Ankom Daisy II incubation bottles (Ankom Technology Corp., Fairport, NY, USA) containing 21 of a $0.1 \mathrm{~N} \mathrm{HCl}$ solution $\left(\mathrm{pH} 1.9 ; 39^{\circ} \mathrm{C}\right)$ with $1 \mathrm{~g}$ per 1 of pepsin (P-7000, Sigma, St. Louis, MO, USA) under constant rotation at $39^{\circ} \mathrm{C}$ for $1 \mathrm{~h}$. Bags were then rinsed with tap water and incubated in a pancreatin solution $\left(0.5 \mathrm{M} \mathrm{KH}_{2} \mathrm{PO}_{4}\right.$ buffer, $\mathrm{pH} 7.75,50 \mathrm{ppm}$ of thymol and $3 \mathrm{~g}$ per 1 of pancreatin; P-7545, Sigma, St. Louis, MO, USA) at $39{ }^{\circ} \mathrm{C}$ for $24 \mathrm{~h}$ under constant rotation. Finally, bags were rinsed with tap water, dried at $40{ }^{\circ} \mathrm{C}$ for $72 \mathrm{~h}$, and weighed. Residues of the in vitro incubation were pooled by sheep and TP sample and analysed for $\mathrm{N}$ concentration to calculate IDCP values.

\section{II.6. Lactation trial}

The trial with dairy goats (Experiment 5 and Paper 6; Appendix) was conducted as a cross-over design with two periods of 37 days each, comprising 21 days of adaptation to diets, and 16 days for measurements and sampling. Over the trial, animals were milked once a day in the morning in a $1 \times 10$ stall milking parlour (DeLaval, Madrid, Spain), and were weighted at the beginning and end of each experimental period. On day 22 of each experimental period, animals were moved to individual metabolism crates and after three-day period of adaptation, total feces and urine voided by each animal were quantitatively collected for five days. Urine was collected into buckets containing 10\% $\mathrm{HCl}$ ( $\mathrm{vol} / \mathrm{vol})$ to keep the $\mathrm{pH}$ below 3 and avoid $\mathrm{N}$ losses. Aliquots $(10 \%)$ of urine were taken daily for density measurement, and immediately 
frozen until analyses of $\mathrm{N}$ content, energy and PD and creatinine concentrations. Samples $(20 \%)$ of total fecal output were collected each day for digestibility determination and stored at $-20{ }^{\circ} \mathrm{C}$ until chemical analyses. Samples of feces and urine were pooled for each goat to form composite samples.

On day 30 goats were moved to floor pens, and on day 31 approximately $20 \mathrm{ml}$ of ruminal fluid was collected from each animal before feeding using a stomach tube attached to a vacuum pump. The fluid was strained through four layers of cheesecloth, the $\mathrm{pH}$ was immediately measured, and $3 \mathrm{ml}$ of ruminal fluid were mixed with $3 \mathrm{ml} 0.5$ $\mathrm{M} \mathrm{HCl}$ and stored frozen until $\mathrm{NH}_{3}-\mathrm{N}$ and VFA analyses. From day 32 to 37, four goats from each dietary treatment were sequentially placed in four individual open circuit respiration chambers (one goat per chamber; two days of measurement) to measure individual methane emissions as described by Romero-Huelva and Molina-Alcaide (2013). Short methane measurement interruptions (10 min) occurred daily at 09:00 $\mathrm{h}$ for diet supply, milking, and chamber floor cleaning, but they had little effect on daily methane emissions as the corresponding exhaust duct was not sampled during this period. Fluxes were determined twice per day and averaged to calculate the 24-hour emissions.

Individual feed and water intake were measured over the trial, but only values measured during the sampling period were used for the statistical analysis. During the sampling period, alfalfa hay and concentrate refusals from each animal were weighted daily, pooled, and stored at $-20{ }^{\circ} \mathrm{C}$ until analyses. Each day of the sampling period, milk yield was recorded, milk density was measured, and aliquots were stored at $-30{ }^{\circ} \mathrm{C}$ without preservatives for chemical analyses.

\section{II.7. Chemical analyses}

All samples used in the in vitro and in vivo studies were ground to pass a $1 \mathrm{~mm}$ screen before chemical analyses. DM (ID 934.01), ash (ID 048.13) and EE (ID 920.39) contents were determined according to the AOAC International (2005) methods. Total $\mathrm{N}$ content was measured using a Leco FP258 Nitrogen Analyzer (Leco Corporation, St. Joseph, MI, USA). Analyses of NDF (Van Soest et al., 1991), ADF and ADL (Robertson and Van Soest, 1981) were carried out sequentially using an Ankom 220 Fibre Analyser unit (Ankom Technology Corp., Fairport, NY, USA). The NDF analyses were performed with $\alpha$-amylase and without sodium sulphite, and NDF, ADF and ADL 
values were expressed exclusive of residual ash. The amount of ADIN was determined by analyzing the $\mathrm{N}$ content in the residue obtained after the treatment of the sample with acid detergent solution. Total sugars and total soluble polyphenols (TSP) were analysed by colorimetric methods following the anthrone method (Yemm and Willis, 1954) and the Folin-Ciocalteu assay (Singleton and Rossi, 1965), respectively, using an Epoch spectrophotometer (BioTek Instruents Inc., Winooski, VT, USA).

Concentrations of $\mathrm{NH}_{3}-\mathrm{N}$ in vial contents in the in vitro incubations were determined by the phenol-hypochlorite method as described by Weatherburn (1967), and those of VFA were conducted by gas chromatography as described by GarcíaMartínez et al. (2005). All analyses were performed in duplicate.

In the study with dairy goats (Experiment 5), energy content of diet ingredients, refusals, and of feces and urine was determined by using an adiabatic calorimeter (model 1356, Parr Instruments Co., Moline, IL, USA). The analyses of VFA and $\mathrm{NH}_{3}-\mathrm{N}$ concentrations in ruminal fluid were performed, respectively by gas chromatography as described by Romero-Huelva and Molina-Alcaide (2013) and by a colorimetric method as proposed by Weatherburn (1967). Total solids in milk were determined by lyophilization of milk samples, and total $\mathrm{N}$ content was analysed by the Dumas method. Non protein- $\mathrm{N}$ was analysed in samples of milk filtrates after precipitation with $12 \%$ (wt/vol) trichloroacetic acid solution. Non casein-N was determined in milk filtrates after precipitation with $10 \%$ (wt/vol) acetic acid at a $\mathrm{pH}$ of 4.1 (Recio et al., 1997). Values of $\mathrm{N}$ in milk were converted to the corresponding protein by multiplying by 6.38. The milk fat content was measured following the Gerber method (Pearson, 1976). Extraction of total FA in samples of alfalfa hay and concentrates was performed following the procedure of Folch et al. (1957), and the FA were methylated according to Kramer and Zhou (2001), with slight modifications, as a double methylation was carried out, using first $\mathrm{NaOH} / \mathrm{methanol}$, at $50{ }^{\circ} \mathrm{C}$ for $15 \mathrm{~min}$, followed by $\mathrm{HCl} / \mathrm{methanol}$ at 50 ${ }^{\circ} \mathrm{C}$ for $1 \mathrm{~h}$ to obtain the FA methyl esters (FAME). For milk FA composition analysis, FA were extracted and transesterified to FAME as described by Abecia et al. (2012). The FAME were separated and quantified using a gas chromatograph (Model Focus GC, Thermo Scientific, Milan, Italy) equipped with a flame-ionization detector and a $100 \mathrm{~m}$ fused silica capillary column $(0.25 \mathrm{~mm}$ i.d., $0.2 \mu \mathrm{m}$ film thickness; SP-Supelco, Bellefonte, PA) and helium as the carrier gas. Total FAME profile in a $1 \mu$ sample volume at a split ratio of 1:50 was determined using a temperature gradient program 
(Shingfield et al., 2003). Nonadecanoic acid (C19:0; Sigma-Aldrich-N5252) was used as an internal standard, and FAME peaks were identified by comparing their retention times with those of standards (47885 U and O5632: Sigma Aldrich, Madrid, Spain; 901093, Larodan Fine Chemicals, Stockholm, Sweden). Results are expressed as percentage of total FAME identified.

Methane concentrations were measured continuously in the air stream in each duct using a gas analyzer ADC MGA3000 (Spurling Works, Herts, UK) as detailed by Romero-Huelva et al. (2017). The concentration of creatinine and PD (PD; allantoine, uric acid, xanthine and hipoxanthine) in urine were determined by HPLC following the method described by Balcells et al. (1992) and the equipment detailed by RomeroHuelva et al. (2017).

In the samples used in the sixth Experiment, analysis of ${ }^{15} \mathrm{~N}$ abundance, NDIN, ADIN and CTAB was performed by combustion using a Thermo 1112 Flash HT elemental analyzer hyphenated interfaced to a Thermo Delta V Advantage isotope ratio mass spectrometer (Thermo Fisher Scientific, Bremen, Germany).

\section{II.8. Calculations and statistical analyses}

Data of gas production obtained for samples of OC, TP and diets including TP were fitted with time using the exponential model Gas $=$ PGP $\times\left(1-\mathrm{e}^{(-c \times(\mathrm{t}-\text { Lag }))}\right)$, where PGP is the potential gas production, $c$ is the fractional rate of gas production, Lag is the time before starting gas production, and $\mathrm{t}$ is the time of gas measurement. Gas production parameters were estimated using the NLIN procedure of SAS (2017) by an iterative least squares procedure. The average gas production rate (AGPR) was calculated as AGPR $=\mathrm{PGP} \times c \div[2 \times(\ln 2+\mathrm{c} \times \operatorname{Lag})]$ and it was defined as the rate between the incubation start and the time at which half PGP is reached. The DM effective degradability (DMED) was estimated as DMED $=[(\mathrm{DMD} 120 \times c) \div(c+\mathrm{Kp})]$

$\times \mathrm{e}^{(-c \times \operatorname{Lag})}$, using a rumen particulate outflow $(\mathrm{Kp})$ of 0.042 per $\mathrm{h}$. Additionally, the amount of fermented OM (FOM) in the Experiments 2, 3 and 4, was calculated from acetate, propionate, and butyrate production in each vial, as described by Demeyer (1991).

In the study on the effects of storage time on the chemical composition and in vitro fermentation of OC (Experiment 1 and Paper 1) gas production and fermentation 
parameters were analysed separately for each group of OC samples (either stored up to six months or from six to eight months). Data were analysed as a mixed model with repeated measures using the PROC MIXED of SAS (2017), in which the effects of the treatment and time were considered fixed and the effect of the inoculum was random. Orthogonal polynomial contrasts were used to test for linear and quadratic effects (only for samples stored until six months) of storage time. Relationships between chemical composition of OC samples and either gas production or fermentation parameters were assessed by correlation analysis using the PROC CORR of SAS (2017).

Data on OC chemical composition in the second Experiment (Paper 2) were analysed using the PROC GLM of SAS (2017) with OC type as the main effect. Data on fermentation parameters were analysed as a mixed model using the PROC MIXED of SAS (2017), where the effect of OC type (COC, EOC and CYOC) was considered fixed and inoculum was considered a random effect. In both models, when effects were significant, means were compared by using the Tukey's test. Pearson correlation coefficients among the chemical composition of OC samples, gas production or fermentation parameters, and storage time of the "alperujo" were assessed using the PROC CORR of SAS (2017). Models to predict the AGPR and FOM were developed using the PROC GLM of SAS, including OC type (COC, EOC and CYOC) as the fixed effect and chemical fractions as linear and quadratic covariates. The interaction between OC type and the chemical composition was also studied. Slopes of the models for different OC types were compared by Student's test. In addition, the accuracy of predicting the AGPR and FOM from OC type and the duration (months) of the "alperujo" storage in ponds as a covariate was evaluated using the same model.

In the Experiment 3 (Paper 5; Appendix), data were analysed as a mixed model using the PROC MIXED of SAS (2017) and comparison of means was performed by the Tukey's test.

In the study with TP samples (Experiment 4 and Paper 3), chemical composition data were analysed using the PROC GLM of SAS (2017) with sampling time as the main effect. In vitro fermentation data from TP samples were analysed as a mixed model with repeated measurements using the PROC MIXED of SAS, in which the effect of sampling time (one to six weeks) was considered fixed and that of the inoculum was considered random. Data from the diets including TP were analysed as a 
mixed model, with the effect of the diet being fixed and that of the inoculum being random. Non-orthogonal polynomial contrasts were used to test for linear and quadratic effects of TP inclusion. Relationships between chemical composition of the TP samples and either gas production or fermentation parameters were assessed by linear regression using the PROC CORR of SAS (2017).

In the study with dairy goats (Experiment 5 and Paper 6; Appendix I), $\mathrm{N}$ and energy balances were calculated as the difference between the amount of $\mathrm{N}$ and energy ingested and that lost in urine, feces and milk, and the energy lost as methane $(0.890$ $\mathrm{MJ} / \mathrm{mol}$ of methane; Newbold et al., 2007). Milk protein-N content was calculated as the difference between total and non protein- $\mathrm{N}$ in milk, whereas the casein- $\mathrm{N}$ concertation $\mathrm{n}$ milk was calculated as the difference between total $\mathrm{N}$ and non casein- $\mathrm{N}$. The amount of whey- $\mathrm{N}$ in milk was calculated as the difference between milk protein and casein-N. Milk lactose was calculated as the difference between the amount of TS and that of protein, fat, and total ash in milk. Data from this study were analysed as a mixed model using the PROC MIXED of SAS (2017), in which the effects of diet, period and their interaction were considered fixed and that of goat was considered random.

Finally, in the sixth Experiment (Paper 4), the possible contamination of ADIN with $\mathrm{N}$ from the CTAB during the ADF analysis was calculated by using Pearson's square method as: (averaged ${ }^{15} \mathrm{~N}$ abundance in total $\mathrm{N}$ and NDIN $-{ }^{15} \mathrm{~N}$ abundance in ADIN)/(averaged ${ }^{15} \mathrm{~N}$ abundance in total $\mathrm{N}$ and NDIN $-{ }^{15} \mathrm{~N}$ abundance in CTAB), in which all ${ }^{15} \mathrm{~N}$ abundances were expressed as atom $\%$. The average ${ }^{15} \mathrm{~N}$ abundance in total $\mathrm{N}$ and NDIN was used in the calculations because of the lack of differences between both values. The ${ }^{15} \mathrm{~N}$ abundance of CTAB was measured (0.3660 atom $\%$ ) and used in the calculations. ${ }^{15} \mathrm{~N}$ abundance values were analysed independently for each feed sample as a mixed model by the PROC MIXED of SAS (SAS, 2017).

In all studies, effects were declared significant at $\mathrm{P}<0.05$, and $\mathrm{P}$-values between 0.05 and 0.10 were considered as a trend. When a significant effect of sampling time was detected, means were compared by Tukey's test.

Additionally, in General Discussion, another method to predict nutrive value of all the samples (OC and TP) used in this Doctoral Thesis was used. This method was based on Neural Networks. Neural Network was a net including two hidden layers with 
four nodes each and a RELU function. Data introduced in the net was standardized. To test the accuracy of the model, four samples of OC and one tample of TP was randomly selected and excluded of the pool of training data. The Neural Network predictive power was then tested in these samples to determine the accuracy of the model. For this, Keras package was used, and the Python script can be found in the Appendix of this Doctoral Thesis. 


\section{Chapter III. INFLUENCE OF}

\section{STORAGE TIME AND}

\section{PROCESSING ON CHEMICAL}

\section{COMPOSITION AND IN VITRO}

\section{RUMINAL FERMENTATION OF}

\section{OLIVE CAKE}

Marcos, C. N., De Evan, T., García-Rebollar, P., De Blas, C., and Carro, M. D. (2019). Influence of storage time and processing on chemical composition and in vitro ruminal fermentation of olive cake. Journal of Animal Physiology and Animal Nutrition 103, 1303-1312. doi: 10.1111/jpn.13149

ISI Journal Citation Reports Ranking 2018: Journal of Animal Physiology and Animal Nutrition was ranked 15 out of 61 Journals in the area of "Agriculture, Dairy \& Animal Science" and 34 out of 141 Journals in the area "Veterinary Sciences" 
Abstract: Olive oil extraction generates olive cake (OC) that could be used in ruminant feeding. However, the chemical composition of OC is affected by multiple factors, being therefore highly variable. The objective of this study was to analyse the influence of storage time and further processing: crude, exhausted (subjected to a second oil extraction) and cyclone (obtained from a cyclone separator) on nutritive value of OC samples. Twelve samples (six crude and six exhausted) were obtained monthly from the same pond from 1 to 6 storage months, and nine samples (three crude, three exhausted and three cyclone) were obtained monthly from a different pond from 6 to 9 months storage. Chemical composition was analysed, and OC samples were fermented in vitro with sheep rumen fluid. Increasing storage time up to 6 months de- creased sugars and total soluble polyphenols content but increased fibre content in OC. Dry matter effective degradability $(\mathrm{DMED})$ decreased linearly $(\mathrm{P}<0.001)$ by 35.9 and $45.5 \%$ as storage time augmented from 1 to 6 months for crude and exhausted OC, respectively. Crude OC had lower DMED values than exhausted OC (averaged values 0.255 and $0.294 \mathrm{~g} / \mathrm{g}$, respectively). Both potential production and rate of gas production were lower ( $\mathrm{P} \leq$ 0.018) in crude compared with exhausted OC, which was attributed to the high fat content of crude OC ( $\geq 86 \mathrm{~g} / \mathrm{kg}$ dry matter). For samples stored longer than 6 months, cyclone had greater $(\mathrm{P}<0.05)$ DMED than crude and exhausted OC (averaged values $0.207,0.164$ and $0.164 \mathrm{~g} / \mathrm{g}$, respectively). The results indicate that ruminal degradability of $\mathrm{OC}$ is reduced with advancing storage time, but only subtle changes were observed during the first two months. Cyclone showed greater degradability than crude and exhausted OC, but differences between crude and exhausted OC became negligible after five storage months.

Keywords: crude olive cake, exhausted olive cake, gas production, in vitro ruminal fermentation, storage time

\section{III.1. Introduction}

Olive oil production is constantly increasing worldwide, but it is still concentrated in the Mediterranean area, with Spain, Greece, Italy and Tunisia being the highest producers and producing $1.27,0.429,0.346$ and 0.280 millions of tons in the 2017/18 campaign (Consejo Oleícola Internacional, 2018). Spain is the largest producer and con- tributes to about $45 \%$ of total world production (MAPA, 2018). The two-phase system, that is currently used in $90 \%$ of Spanish olive mills to obtain olive oil, generates 
annually more than $4.3 \times 10^{6}$ t of a high-moisture waste called "alperujo" (Callejo et al., 2015). The alperujo is a thick sludge that contains pieces of stone, pulp from the olive fruits and variable amounts of vegetable water and oil (Molina-Alcaide and Yáñez-Ruiz, 2008), and is a major eco- logical issue due to its high organic load, low pH and high oxygen demand (Dermeche et al., 2013). As large volumes of alperujo are generated in a brief period of olive oil production, usually November to February in the Mediterranean countries, the environmental problem is further aggravated (Alburquerque et al., 2004). The alperujo is sent to extraction plants (“orujeras") where it is stored in large ponds, sometimes for several months, before being further processed. Processing can consist in removing the stones and drying the residue off, thus generating a by-product called olive cake (OC), which can be pelleted and used in animal feeding (crude OC). Alternatively, OC can be subjected to a chemical extraction, using hexane or other authorized food-grade solvents to obtain pomace olive oil, and this process generates "exhausted OC" as a by-product. Exhausted OC is currently mostly used to produce biofuel but could also be used in ruminant feeding.

The use of OC in ruminant feeding would increase its economic value and contribute to alleviate the environmental problem, but its chemical composition and nutritive value are highly variable (Molina-Alcaide and Yáñez-Ruiz, 2008), being influenced by different factors such as the olive cultivar, ripeness of the fruit, climate and agronomic conditions, storage conditions and processing techniques (Dermeche et al., 2013). In the practice, storing time of OC is variable, as processing of alperujo depends on the priorities of the ex- traction plant. However, to the best of our knowledge, there is no information on the influence of storage time on nutritive value of OC for ruminants. Therefore, the objective of this study was to assess chemical composition and in vitro ruminal fermentation of crude and exhausted OC samples obtained at different storage times. In addition, the relationships between chemical composition and in vitro fermentation parameters were studied.

\section{III.2. Materials and methods}

\section{III.2.1. Olive cake samples}

A total of 21 samples of OC were obtained at an extraction plant located at Puente Genil (Córdoba, Spain). The first group of 12 samples were obtained at monthly intervals from a single pond (A) from December (1 month storage) to May (6 months 
storage). Ponds were located in south Spain under Mediterranean-Continental weather conditions, characterized by mild winters and hot summers and low annual rains mainly produced in autumn and spring. Samples were either dried and pelletized (crude OC; AC1 to AC6) or dried and subjected to a second oil extraction using hexane (exhausted OC; AE1 to AE6). The rest of the samples were obtained from a different pond (B) at monthly intervals from May (6 months storage) to July (8 months storage). Samples were dried and pelletized (BC6 to BC8), dried and extracted with hexane (BE6 to BE8) or obtained from a cyclone separator after the drying process (BCY6 to BCY8). The cyclone was used as an air pollution control device, as it removed particulate matter from the dirty air resulting from alperujo drying. All samples were ground $(1 \mathrm{~mm}$ screen) before analysis of chemical composition and in vitro incubations.

\section{III.2.2. Animals and in vitro incubations}

Ruminal fluid used as inoculum was obtained from four rumen-cannulated Lacaune sheep $(64.7 \pm 2.10 \mathrm{~kg}$ body weight $)$, which were managed according to the protocols approved by the Institutional Animal Care and Use Committee of the Comunidad Autónoma de Madrid (PROEX 035/17). Sheep were fed grass hay and concentrate in 2:1 proportion twice daily ( $8: 00$ and 18:00 hr) at a rate of $45 \mathrm{~g}$ dry matter $(\mathrm{DM}) / \mathrm{kg}$ live weight ${ }^{0.75}$ and had free access to fresh water over the trial.

Two different in vitro incubations were performed using the same methodology. Two hundred $\mathrm{mg}$ of DM of each sample was weighed into $60 \mathrm{ml}$ serum vials. Ruminal contents of each sheep were obtained immediately before the morning feeding, strained through four layers of cheesecloth into previously warmed thermal flasks, and immediately transported to the laboratory. The fluid of each sheep was independently mixed with pre-warmed $\left(39^{\circ} \mathrm{C}\right)$ culture medium of Goering and Van Soest (1970) (no trypticase added) in a proportion 1:4 under continuous $\mathrm{CO}_{2}$ flushing. Vials were prewarmed $\left(39^{\circ} \mathrm{C}\right)$ prior to the addition of $20 \mathrm{ml}$ of the mixture, sealed with rubber stoppers and placed in an incubator at $39^{\circ} \mathrm{C}$.

The first incubation trial was conducted to determine gas production kinetics, and vials were incubated for $120 \mathrm{hr}$. Gas production was measured at 3, 6, 9, 12, 15, 22, 26, 31, 36, 48, 58, 72, 96 and $120 \mathrm{hr}$ using a pressure transducer (Widereager Wide Range Pressure Meter, Sper Scientific LTD) and a plastic syringe, and the gas produced at each measurement time was released. Vials without OC samples (blanks; two per 
inoculum) were also incubated to correct for endogenous gas production. The second incubation trial analysed the main fermentation parameters. Vials were incubated for 24 $\mathrm{hr}$ before measuring gas production as before described. Vials were then uncapped, the $\mathrm{pH}$ was measured immediately (Crison Basic $20 \mathrm{pH}$ meter; Crison Instruments) and 3 $\mathrm{ml}$ of vials content were mixed with $3 \mathrm{ml}$ of $\mathrm{HCl} 0.5 \mathrm{~N}$. The obtained mixtures were stored at $-20{ }^{\circ} \mathrm{C}$ until volatile fatty acid (VFA) and $\mathrm{NH}_{3}-\mathrm{N}$ analyses were performed. Within each trial, incubations were performed in four different days, and each day the rumen fluid from one sheep was used as inoculum to obtain four replicates per experimental treatment.

\section{III.2.3. In vitro degradability}

The in vitro DM and neutral detergent fibre (NDF) degradabilities (DMD and NDFD, respectively) were determined by weighing $300 \mathrm{mg}$ of samples in polyester bags (30 $\mu \mathrm{m}$ pore size; Ankom Corp \#57, Ankom Technology Corp) which were incubated with buffered ruminal fluid in an Ankom Daisy II incubator (Ankom Technology Corp) at $39{ }^{\circ} \mathrm{C}$ under continuous rotation. Ruminal fluid was obtained from each sheep as described before and equally mixed before conducting the incubations. After $48 \mathrm{hr}$, bags were washed with cold water, dried at $60{ }^{\circ} \mathrm{C}$ for $48 \mathrm{hr}$ and weighed to calculate the DMD. Bags were then extracted with boiling neutral detergent solution (Van Soest et al., 1991) for $1 \mathrm{hr}$ using an Ankom220 Fibre Analyser unit (Ankom Technology Corp), dried at $60^{\circ} \mathrm{C}$ for $48 \mathrm{hr}$ and weighed to calculate the NDFD. Finally, potential in vitro DM degradability (DMD120) was determined as described before with the exception that incubation lasted for $120 \mathrm{hr}$ (Vanegas et al., 2017). After $120 \mathrm{hr}$, bags were washed with cold water, dried at $60{ }^{\circ} \mathrm{C}$ for $48 \mathrm{hr}$ and weighed to calculate the DMD120. In all cases, three bags were used for each sample.

\section{III.2.4. Chemical analyses}

Dry matter (ID 934.01) and ash (ID 048.13) contents were determined according to the AOAC International methods (AOAC, 2005). Total $\mathrm{N}$ content was measured using a Leco FP258 Nitrogen Analyzer (Leco Corporation). Ether extract (EE) content was measured by extraction with petroleum ether (AOAC Method 945.16) using an Ankom XT10 extractor (Ankom Technology Corp).

Neutral detergent fibre analyses were carried out as described by Van Soest et al. 
(1991) and those of acid detergent fibre (ADF) and acid detergent lignin (ADL) followed the procedures of Robertson and Van Soest (1981), results were expressed exclusive of residual ash. Acid detergent insoluble nitrogen (ADIN) was measured using a Leco FP258 Nitrogen Analyzer (Leco Corporation) after ADF extraction. Sugars content was determined in defatted samples by the Anthrone method as described by Yemm and Willis (1954) using an Epoch spectrophotometer (BioTek Instruments Inc). Total soluble polyphenols (TSP) were determined by the FolinCiocalteu assay (Singleton and Rossi, 1965) using an Epoch spectrophotometer (BioTek Instruments Inc).

Samples of vials content were defrosted, centrifuged $\left(13,000 \times \mathrm{g}, 20 \mathrm{~min}, 4{ }^{\circ} \mathrm{C}\right)$ and the supernatant was used to analyse $\mathrm{NH}_{3}-\mathrm{N}$ concentrations by a modified colorimetric method (Weatherburn, 1967). For VFA analyses, $0.8 \mathrm{ml}$ of the supernatant were added to $0.5 \mathrm{ml}$ of deproteinizing solution $(20 \mathrm{~g} / 1$ metaphosphoric acid and $0.6 \mathrm{~g} / \mathrm{l}$ crotonic acid) and the mixture was kept at $4{ }^{\circ} \mathrm{C}$ for $24 \mathrm{hr}$. Samples were centrifuged again under the same conditions listed above, and the supernatant was transferred to vials for determination of VFA by gas chromatography (García-Martínez et al., 2005).

III.2.5. Calculations and statistical analyses

Gas production data were fitted with time using the exponential model:

$$
\text { Gas }=P G P\left(1-e^{(-c(t-l a g))}\right)
$$

where PGP is the asymptotic gas production $(\mathrm{ml}), c$ is the fractional rate of gas production ( $\mathrm{h}-1)$, lag is the time before gas production begins (hr), and $\mathrm{t}$ is the time of gas measurement. The parameters PGP, $c$ and lag were estimated using the NLIN procedure of SAS (version 9.2; SAS Inst. Inc) by an iterative least squares procedure. The average gas production rate (AGPR; $\mathrm{ml}$ gas $/ \mathrm{hr}$ ) was calculated as

$$
A G P R=\frac{P G P * c}{[2(\ln 2+c * \operatorname{lag})]}
$$

and was defined as the average gas production rate between the start of the incubation and the time when half of the PGP was reached. Finally, the DMED was estimated assuming a rumen particulate outflow $(\mathrm{Kp})$ of 0.04 per hour according to the equation proposed by France et al. (2000): 


$$
D M E D=\frac{D M D_{120} * c}{c+K p} * e^{(-c * l a g)}
$$

Gas production and fermentation parameters were analysed separately for each group of OC samples (pond A or B). Data were analysed as a mixed model with repeated measures using the PROC MIXED of SAS, in which the effects of the treatment and time were considered fixed and the effect of the inoculum was random. Orthogonal polynomial contrasts were used to test for linear and quadratic effects (only for samples from pond A) of storage time. Significance was declared at $\mathrm{P} \leq 0.05$. Relationships between chemical composition of OC samples and either gas production or fermentation parameters were assessed by correlation analysis using the PROC CORR of SAS.

\section{III.3. Results and discussion}

\section{III.3.1. Chemical composition of olive cake}

Proportions of chemical fractions in OC samples (Table 4) were within the range reported in previous studies (Molina-Alcaide and Yáñez-Ruiz, 2008; Alburquerque et al., 2004; Molina-Alcaide and Nefzaoui, 1996). Increasing storage time of OC samples from 1 to 6 months resulted in augmented NDF, ADF and ADL contents, thus reflecting the greater resistance of cell wall components to biodegradation compared to other chemical fractions. As expected, for both groups of samples EE content was greater in crude OC samples compared with exhausted OC due to the second oil extraction. There was no clear effect of storage time on $\mathrm{N}$ content for any group of OC samples, but in accordance with previous studies (reviewed by Molina-Alcaide and Yáñez-Ruiz, 2008) a great proportion of $\mathrm{N}(39.1 \%-72.1 \%)$ was bound to acid detergent fibre, indicating low N availability. Sugars and TSP contents clearly decreased as storage time increased from 1 to 6 months, but changes from 6 to 8 storage months were less marked. Alburquerque et al. (2006) also observed that TSP content of OC decreased linearly over a 12-month composting period, and Alhamad et al. (2017) reported similar results through a 2-month fermentation period. As discussed by Alburquerque et al. (2006), enzymes contained in OC (i.e., phenol-oxidase and $\beta$-glucosidase) may remove phenols by oxidizing low-molecular weight phenolic compounds, which can be polymerized to produce less soluble substances (Greco et al., 1999). In addition, several microbial 
groups can contribute to phenol degradation (Martínez et al., 1993), and therefore both enzymatic and microbial processes can lead to decreased TSP content as storage time progresses.

Both DMD and NDFD decreased as storage time augmented from 1 to 6 months, but the drop was more pronounced in exhausted OC (dropped by $47.0 \%$ for DMD and by $45.6 \%$ for NDFD) than in crude OC (43.1\% for DMD and $14.7 \%$ for NDFD). Decreases in DMD and NDFD from 6 to 8 storage months were less pronounced (26.4 and $38.5,30.0$, and 16.9 , and 21.4 and $11.2 \%$ for crude, exhausted and cyclone samples, respectively). The reduction in DMD with advancing storage time is consistent with the changes in chemical composition. In fact, DMD values were negatively correlated with NDF $(\mathrm{P}=0.021)$ and ADF $(\mathrm{P}=0.045)$ content and positively correlated $(\mathrm{P}<0.001)$ with sugars content (Table 5). 
Table 4. Chemical composition and in vitro dry matter (DMD) and neutral detergent fibre (NDFD) degradability of olive cake samples obtained after different storage time in ponds and processing.

\begin{tabular}{|c|c|c|c|c|c|c|c|c|c|c|c|c|c|c|c|}
\hline \multirow[b]{2}{*}{ Pond } & \multirow[b]{2}{*}{ Sample } & \multirow[b]{2}{*}{$\begin{array}{c}\text { Storage } \\
\text { time } \\
\text { (months) }\end{array}$} & \multirow[b]{2}{*}{ Processing $^{1}$} & \multirow[b]{2}{*}{$\begin{array}{c}\text { Dry } \\
\text { matter } \\
\text { (g/kg) }\end{array}$} & \multicolumn{11}{|c|}{ g/kg dry matter (DM) unless otherwise stated } \\
\hline & & & & & $\begin{array}{c}\text { Organic } \\
\text { matter }\end{array}$ & $\begin{array}{c}\text { Neutral } \\
\text { detergent } \\
\text { fibre }\end{array}$ & $\begin{array}{c}\text { Acid } \\
\text { detergent } \\
\text { fibre } \\
\end{array}$ & $\begin{array}{c}\text { Acid } \\
\text { detergent } \\
\text { lignin }\end{array}$ & $\begin{array}{l}\text { Nitrogen } \\
\text { (N) }\end{array}$ & ADIN & $\mathbf{E E}$ & $\begin{array}{l}\text { Total } \\
\text { sugars }\end{array}$ & TSP & DMD & NDFD \\
\hline \multirow{12}{*}{ A } & $\mathrm{ACl}$ & 1 & \multirow{6}{*}{ Crude } & 924 & 931 & 445 & 325 & 172 & 13.8 & 7.6 & 104 & 202 & 12.2 & 0.483 & 0.218 \\
\hline & $\mathrm{AC} 2$ & 2 & & 898 & 925 & 494 & 365 & 191 & 15.5 & 9.6 & 118 & 106 & 11.5 & 0.438 & 0.214 \\
\hline & $\mathrm{AC} 3$ & 3 & & 906 & 925 & 513 & 366 & 182 & 15.6 & 8.3 & 86 & 80 & 12.4 & 0.439 & 0.213 \\
\hline & $\mathrm{AC} 4$ & 4 & & 888 & 928 & 617 & 438 & 209 & 16.2 & 9.3 & 118 & 33 & 9.6 & 0.328 & 0.212 \\
\hline & AC5 & 5 & & 921 & 948 & 652 & 453 & 204 & 14.9 & 7.0 & 103 & 33 & 7.7 & 0.304 & 0.185 \\
\hline & AC6 & 6 & & 862 & 934 & 706 & 501 & 250 & 16.5 & 11.9 & 100 & 34 & 6.4 & 0.275 & 0.186 \\
\hline & AE1 & 1 & \multirow{6}{*}{ Exhausted } & 869 & 923 & 528 & 385 & 209 & 16.5 & 10.4 & 5 & 197 & 26 & 0.568 & 0.329 \\
\hline & AE2 & 2 & & 899 & 919 & 538 & 387 & 204 & 16 & 10.4 & 27 & 106 & 29.2 & 0.556 & 0.335 \\
\hline & AE3 & 3 & & 898 & 925 & 559 & 398 & 197 & 15.8 & 8.0 & 22 & 80 & 25.3 & 0.494 & 0.222 \\
\hline & AE4 & 4 & & 887 & 916 & 661 & 469 & 223 & 17.8 & 9.7 & 32 & 47 & 22.8 & 0.398 & 0.218 \\
\hline & AE5 & 5 & & 908 & 935 & 751 & 511 & 233 & 17.3 & 7.8 & 22 & 33 & 16.7 & 0.307 & 0.208 \\
\hline & AE6 & 6 & & 873 & 934 & 766 & 533 & 261 & 17.4 & 11 & 5 & 22 & 15.4 & 0.301 & 0.179 \\
\hline \multirow{9}{*}{ B } & $\mathrm{BC} 7$ & 6 & \multirow{3}{*}{ Crude } & 924 & 912 & 495 & 355 & 184 & 18.1 & 8.3 & 131 & 11 & 14.8 & 0.337 & 0.122 \\
\hline & $\mathrm{BC} 8$ & 7 & & 932 & 941 & 574 & 389 & 197 & 13.3 & 5.2 & 111 & 8 & 9.3 & 0.256 & 0.081 \\
\hline & BC9 & 8 & & 924 & 905 & 554 & 389 & 200 & 17.6 & 7.3 & 145 & 10 & 10.6 & 0.248 & 0.075 \\
\hline & BE6 & 6 & \multirow{3}{*}{ Exhausted } & 860 & 894 & 606 & 434 & 234 & 23.5 & 12.2 & 4 & 15 & 11.6 & 0.36 & 0.160 \\
\hline & BE7 & 7 & & 903 & 920 & 697 & 471 & 214 & 17.4 & 9.1 & 21 & 8 & 10.4 & 0.256 & 0.100 \\
\hline & BE8 & 8 & & 873 & 908 & 695 & 494 & 248 & 18.7 & 9.2 & 5 & 12 & 8.61 & 0.252 & 0.133 \\
\hline & BCY6 & 6 & \multirow{3}{*}{ Cyclone } & 930 & 901 & 424 & 306 & 177 & 21.1 & 9.4 & 148 & 14 & 16 & 0.398 & 0.17 \\
\hline & BCY7 & 7 & & 944 & 910 & 426 & 291 & 136 & 20.2 & 9.1 & 172 & 16 & 14.7 & 0.381 & 0.145 \\
\hline & $\mathrm{BCY} 8$ & 8 & & 917 & 887 & 454 & 321 & 190 & 22.2 & 10.8 & 195 & 11 & 11.8 & 0.313 & 0.151 \\
\hline
\end{tabular}

${ }^{\mathrm{T}}$ Crude samples were dried and pelletized; Exhausted samples were dried and subjected to an extraction using hexane; Cyclone samples were obtained from a cyclone separator after drying the crude samples 
Table 5. Correlation matrix (Pearson coefficient and P-values in brackets; $n=21$ ) of chemical composition of OC samples with gas production parameters, in vitro degradability and fermentation parameters in $24 \mathrm{hr}$ in vitro incubations (only P-values $\leq 0.10$ values are shown).

\begin{tabular}{|c|c|c|c|c|c|c|c|}
\hline & $\begin{array}{c}\text { Neutral detergent } \\
\text { fibre }\end{array}$ & $\begin{array}{c}\text { Acid detergent } \\
\text { fibre }\end{array}$ & $\begin{array}{c}\text { Acid detergent } \\
\text { lignin }\end{array}$ & Nitrogen & Ether extract & Sugars & $\begin{array}{l}\text { Total soluble } \\
\text { polyphenols } \\
\end{array}$ \\
\hline \multicolumn{8}{|c|}{ Gas production parameters } \\
\hline PGP & $-0.52(0.015)$ & $-0.47(0.031)$ & $-0.43(0.050)$ & - & - & $0.87(<0.001)$ & $0.70(<0.001)$ \\
\hline$c$ & - & $0.39(0.079)$ & $0.40(0.076)$ & $-0.45(0.044)$ & $-0.58(0.006)$ & $0.59(0.005)$ & - \\
\hline Lag & - & - & - & - & - & $0.50(0.020)$ & - \\
\hline AGPR & - & - & - & $-0.43(0.055)$ & - & $0.90(<0.001)$ & $0.66(0.001)$ \\
\hline DMED & $-0.34(0.021)$ & $-0.44(0.045)$ & - & - & - & $0.82(<0.001)$ & $0.77(<0.001)$ \\
\hline \multicolumn{8}{|c|}{ In vitro degradability } \\
\hline DMD & $-0.50(0.021)$ & $-0.44(0.045)$ & - & - & - & $0.82(<0.001)$ & $0.77(<0.001)$ \\
\hline NDFD & - & - & - & - & $-0.38(0.088)$ & $0.75(<0.001)$ & $0.70(<0.001)$ \\
\hline \multicolumn{8}{|c|}{ In vitro fermentation parameters } \\
\hline Gas & $-0.45(0.038)$ & $-0.44(0.030)$ & - & - & - & $0.89(<0.001)$ & $0.68(<0.001)$ \\
\hline $\mathrm{pH}$ & $0.39(0.082)$ & - & - & $0.45(0.043)$ & - & $-0.89(<0.001)$ & $-0.66(0.001)$ \\
\hline $\mathrm{NH}_{3}-\mathrm{N}$ & - & - & - & - & - & $-0.53(0.014)$ & $-0.69(<0.001)$ \\
\hline Total VFA & $-0.60(0.004)$ & $-0.56(0.009)$ & $-0.52(0.015)$ & - & - & $0.84(<0.001)$ & $0.65(0.001)$ \\
\hline Acetate & $-0.58(0.006)$ & $-0.54(0.011)$ & $-0.51(0.018)$ & - & - & $0.85(<0.001)$ & $0.64(0.002)$ \\
\hline Propionate & $-0.56(0.009)$ & $-0.51(0.019)$ & $-0.47(0.033)$ & - & - & $0.86(<0.001)$ & $0.67(0.001)$ \\
\hline Butyrate & $-0.68(<0.001)$ & $-0.66(0.001)$ & $-0.61(0.004)$ & - & - & $0.77(<0.001)$ & $0.68(<0.001)$ \\
\hline Minor VFA $^{1}$ & $-0.40(0.074)$ & $-0.46(0.037)$ & $-0.47(0.033)$ & $0.39(0.080)$ & $0.52(0.016)$ & $-0.48(0.027)$ & $-0.42(0.059)$ \\
\hline
\end{tabular}

${ }^{1}$ Calculated as the sum of isobutyrate, isovalerate and valerate. 
III.3.2. Effects of storage time on in vitro fermentation of olive cake

Values of PGP and AGPR were linearly reduced $(\mathrm{P}<0.001)$ by increasing storage time from 1 to 6 months (Table 6), whereas $\mathrm{c}$ and Lag values decreased and tended to decrease quadratically $(\mathrm{P}<0.001$ and 0.075 , respectively). Similarly, in the samples stored from 6 to 8 months (Table 7) values of PGP, c and AGPR were reduced linearly $(\mathrm{P} \leq 0.007)$ with advancing storage time, but Lag was unaffected $(\mathrm{P}>0.05)$.

The linear decrease $(P<0.001)$ of PGP and AGPR values with increasing storage time from 1 to 6 months (Table 6) is in accordance with the changes observed in chemical composition of OC samples. In fact, PGP was negatively correlated $(\mathrm{P} \leq$ $0.050)$ with NDF, ADF and ADL content, and positively $(\mathrm{P}<0.001)$ with sugars and TSP content (Table 5). Both NDF and ADF are less degradable than other fractions (i.e., N, sugars,...), and therefore their fermentation produces lower amounts of gas. In contrast, sugars are rapidly and extensively fermented by rumen microorganisms, and in agreement with our results positive correlations between sugars content and both rate and extent of gas production have been reported for other feedstuffs (Piquer et al., 2009). Polyphenols are secondary compounds that can reduce ruminal degradation of fibre by decreasing the attachment of microbes to feed particles (Theodorou et al., 2006), and negative correlations between TSP content and DM degradability are frequently reported (Molina-Alcaide et al., 2017). The positive relationship ( $\mathrm{P} \leq 0.001)$ between TSP content and PGP, AGPR, DMED, DMD and NDFD seem to be the consequence of the similar changes produced in all these variables as storage time augmented than to a direct effect of TSP on samples degradation.

Values of DMED decreased linearly $(\mathrm{P}<0.001)$ with advancing time over the first 6 months of storage, with reductions being less marked for crude (regression slope $-0.026 \pm 0.0050)$ than for exhausted OC $(-0.041 \pm 0.0053)$. Increasing storage time from 6 to 8 months also reduced linearly DMED $(\mathrm{P}<0.001)$. The low values of DMED of OC samples, ranging from 0.130 to $0.382 \mathrm{~g} / \mathrm{g}$, agree well with the results from other studies reviewed by Molina-Alcaide and Yáñez-Ruiz (2008), who reported an average value of 0.27 for in vitro DM apparent digestibility. 
Table 6. Effect of processing (PR) and storage time in pond (Time) of olive cake (OC) samples on gas production kinetics parameters.

\begin{tabular}{|c|c|c|c|c|c|c|c|c|c|c|c|c|}
\hline \multirow{3}{*}{ Item $^{1}$} & \multirow{3}{*}{$\mathbf{P R}^{2}$} & \multirow{2}{*}{\multicolumn{6}{|c|}{ Storage time (months) Time }} & \multirow{3}{*}{$\operatorname{SEM}_{P R}^{3}$} & \multirow{3}{*}{ SEM $_{\text {Time }}{ }^{4}$} & \multicolumn{3}{|c|}{ P-value } \\
\hline & & & & & & & & & & \multirow{2}{*}{ PR } & \multicolumn{2}{|c|}{ Time } \\
\hline & & 1 & 2 & 3 & 4 & 5 & 6 & & & & Linear & Quadratic \\
\hline \multirow{2}{*}{ PGP (ml/g DM) } & ACOC & 119 & 97.7 & 95.1 & 72.7 & 60.5 & 51.7 & \multirow{2}{*}{2.93} & \multirow{2}{*}{3.45} & \multirow{2}{*}{$<0.001$} & \multirow{2}{*}{$<0.001$} & \multirow{2}{*}{0.262} \\
\hline & AEOC & 122 & 122 & 99.8 & 86.2 & 69.3 & 50.7 & & & & & \\
\hline \multirow{2}{*}{$c\left(\mathrm{~h}^{-1}\right)$} & ACOC & 0.057 & 0.060 & 0.063 & 0.050 & 0.042 & 0.067 & \multirow{2}{*}{0.0028} & \multirow{2}{*}{0.0031} & \multirow{2}{*}{0.018} & \multirow{2}{*}{0.493} & \multirow{2}{*}{$<0.001$} \\
\hline & AEOC & 0.065 & 0.059 & 0.058 & 0.054 & 0.054 & 0.068 & & & & & \\
\hline \multirow{2}{*}{$\operatorname{Lag}(\mathrm{hr})$} & ACOC & 0.54 & 0.34 & 0.68 & 0.00 & 0.00 & 0.45 & \multirow{2}{*}{0.170} & \multirow{2}{*}{0.209} & \multirow{2}{*}{0.839} & \multirow{2}{*}{0.557} & \multirow{2}{*}{0.075} \\
\hline & AEOC & 0.31 & 0.35 & 0.46 & 0.00 & 0.00 & 0.74 & & & & & \\
\hline \multirow{2}{*}{ AGPR (ml/hr) } & ACOC & 4.62 & 4.09 & 4.00 & 2.58 & 1.82 & 2.38 & \multirow{2}{*}{0.066} & \multirow{2}{*}{0.104} & \multirow{2}{*}{$<0.001$} & \multirow{2}{*}{$<0.001$} & \multirow{2}{*}{0.011} \\
\hline & AEOC & 5.47 & 5.03 & 3.98 & 3.32 & 2.69 & 2.33 & & & & & \\
\hline \multirow{2}{*}{$\operatorname{DMED}(\%)$} & $\mathrm{ACOC}$ & 0.320 & 0.283 & 0.291 & 0.242 & 0.186 & 0.205 & \multirow{2}{*}{0.0037} & \multirow{2}{*}{0.0064} & \multirow{2}{*}{$<0.001$} & & \\
\hline & AEOC & 0.382 & 0.376 & 0.311 & 0.283 & 0.201 & 0.208 & & & & $<0.001$ & 0.868 \\
\hline
\end{tabular}

${ }^{\mathrm{T}}$ AGRP, gas production rate until it has reached half of the PGP; c, fractional rate of gas production; DMED, effective degradability of dry matter calculated for a rumen passage rate of 0.04 per hour; Lag, time until the production of gas begins; PGP, potential gas production; ${ }^{2} \mathrm{ACOC}$, crude olive cake (samples AC1 to AC6); AEOC, exhausted olive cake (samples AE1 to AE6); ${ }^{3}$ standard error of the mean for processing effect; ${ }^{4}$ standard error of the mean for time effect. 
Table 7. Effect of processing (PR) and storage time in pond (Time) of olive cake (OC) samples on gas production kinetics parameters.

\begin{tabular}{|c|c|c|c|c|c|c|c|c|}
\hline \multirow{2}{*}{ Item $^{1}$} & \multirow{2}{*}{$\mathbf{P R}^{2}$} & \multicolumn{3}{|c|}{ Storage time (months) } & \multirow{2}{*}{$\operatorname{SEM}_{P R}{ }^{3}$} & \multirow{2}{*}{$\operatorname{SEM}_{\text {Time }}{ }^{4}$} & \multicolumn{2}{|c|}{ P-value } \\
\hline & & 6 & 7 & 8 & & & PR & Time $^{\mathrm{a}}$ \\
\hline \multirow{4}{*}{ PGP (ml/g DM) } & $\mathrm{BCOC}^{\mathrm{a}}$ & 68.5 & 51.5 & 50.2 & & & & \\
\hline & $\mathrm{BEOC}^{\mathrm{a}}$ & 63.2 & 48.5 & 40.9 & 2.91 & 2.91 & $<0.001$ & $<0.001$ \\
\hline & $\mathrm{BCYO}^{\mathrm{b}}$ & 72.7 & 79.8 & 65.8 & & & & \\
\hline & $\mathrm{BCOC}^{\mathrm{a}}$ & 0.033 & 0.037 & 0.026 & & & & \\
\hline \multirow[t]{2}{*}{$c\left(\mathrm{~h}^{-1}\right)$} & $\mathrm{BEOC}^{\mathrm{b}}$ & 0.044 & 0.041 & 0.045 & 0.0024 & 0.0024 & $<0.001$ & 0.007 \\
\hline & $\mathrm{BCYO}^{\mathrm{a}}$ & 0.039 & 0.036 & 0.026 & & & & \\
\hline \multirow{3}{*}{$\operatorname{Lag}(\mathrm{hr})$} & $\mathrm{BCOC}$ & 0.00 & 0.00 & 0.00 & & & & \\
\hline & $\mathrm{BEOC}$ & 0.00 & 0.00 & 0.00 & 0.066 & 0.066 & 0.123 & 0.244 \\
\hline & BCYO & 0.33 & 0.18 & 0.00 & & & & \\
\hline \multirow{3}{*}{$\operatorname{AGPR}(\mathrm{ml} / \mathrm{hr})$} & $\mathrm{BCOC}^{\mathrm{a}}$ & 1.61 & 1.36 & 0.95 & & & & \\
\hline & $\mathrm{BEOC}^{\mathrm{b}}$ & 2.04 & 1.44 & 1.32 & 0.118 & 0.118 & $<0.001$ & $<0.001$ \\
\hline & $\mathrm{BCYO}^{\mathrm{b}}$ & 1.99 & 2.05 & 1.21 & & & & \\
\hline \multirow{3}{*}{$\operatorname{DMED}(\mathrm{g} / \mathrm{g})$} & $\mathrm{BCOC}^{\mathrm{a}}$ & 0.207 & 0.155 & 0.130 & & & & \\
\hline & $\mathrm{BEOC}^{\mathrm{a}}$ & 0.197 & 0.148 & 0.147 & 0.0065 & 0.0065 & $<0.001$ & $<0.001$ \\
\hline & $\mathrm{BCYO}^{\mathrm{b}}$ & 0.255 & 0.223 & 0.144 & & & & \\
\hline
\end{tabular}

${ }^{\mathrm{T}}$ AGRP, gas production rate until it has reached half of the PGP; c, fractional rate of gas production; DMED, effective degradability of dry matter calculated for a rumen passage rate of 0.04 per hour; Lag, time until the production of gas begins; PGP, potential gas production; ${ }^{2} \mathrm{BCOC}$, crude olive cake (samples BCOC6 to BCOC8); BCYOC, obtained from a cyclone separator after drying the OC (samples BCYOC6 to BCYOC8); BEOC, exhausted olive cake (samples BEOC6 to BEOC8); ${ }^{3}$ standard error of the mean for processing effect; ${ }^{4}$ standard error of the mean for time effect.

${ }^{\mathrm{a}, \mathrm{b}}$ Within each parameter, different superscripts indicate differences among treatments $(\mathrm{P}<0.05)$.

${ }^{\text {a }}$ Linear effect of time. 
Table 8. Effect of processing (PR) and storage time in the pond (Time) of olive cake (OC) samples on fermentation parameters in 24 hr in vitro ruminal fermentation.

\begin{tabular}{|c|c|c|c|c|c|c|c|c|c|c|c|c|}
\hline \multirow{3}{*}{ Item } & \multirow{3}{*}{$\mathbf{P R}^{1}$} & \multirow{2}{*}{\multicolumn{6}{|c|}{ Storage time (months) Time }} & \multirow{3}{*}{$\operatorname{SEM}_{P R}^{2}$} & \multirow{3}{*}{ SEM $_{\text {Time }}{ }^{3}$} & \multicolumn{3}{|c|}{ P-value } \\
\hline & & & & & & & & & & \multirow{2}{*}{$\mathbf{P R}$} & \multicolumn{2}{|c|}{ Time } \\
\hline & & 1 & 2 & 3 & 4 & 5 & 6 & & & & Linear & Quadratic \\
\hline \multirow{2}{*}{ Gas $(\mathrm{ml} / \mathrm{g}$ dry matter $(\mathrm{DM}))$} & $\mathrm{ACOC}$ & 92.5 & 72.5 & 73.0 & 56.0 & 47.5 & 43.0 & \multirow{2}{*}{1.55} & \multirow{2}{*}{2.40} & \multirow{2}{*}{$<0.001$} & \multirow{2}{*}{$<0.001$} & \multirow{2}{*}{0.074} \\
\hline & AEOC & 98.5 & 96.0 & 71.0 & 66.0 & 52.0 & 47.0 & & & & & \\
\hline \multirow{2}{*}{$\mathrm{pH}$} & $\mathrm{ACOC}$ & 6.78 & 6.87 & 6.90 & 6.97 & 7.04 & 7.08 & \multirow{2}{*}{0.010} & \multirow{2}{*}{0.014} & \multirow{2}{*}{0.004} & \multirow{2}{*}{$<0.001$} & \multirow{2}{*}{0.274} \\
\hline & AEOC & 6.77 & 6.79 & 6.89 & 6.90 & 7.00 & 7.09 & & & & & \\
\hline \multicolumn{13}{|c|}{ Volatile fatty acids (VFA; mmol/g DM) } \\
\hline \multirow{2}{*}{ Total } & $\mathrm{ACOC}$ & 4.54 & 4.06 & 3.98 & 3.38 & 3.08 & 2.39 & \multirow{2}{*}{0.254} & \multirow{2}{*}{0.259} & \multirow{2}{*}{$<0.001$} & \multirow{2}{*}{$<0.001$} & \multirow{2}{*}{0.211} \\
\hline & AEOC & 4.82 & 4.51 & 3.74 & 3.66 & 3.24 & 2.74 & & & & & \\
\hline \multirow{2}{*}{ Acetate } & $\mathrm{ACOC}$ & 2.89 & 2.57 & 2.52 & 2.10 & 1.92 & 1.40 & \multirow{2}{*}{0.148} & \multirow{2}{*}{0.152} & \multirow{2}{*}{$<0.001$} & \multirow{2}{*}{$<0.001$} & \\
\hline & AEOC & 3.05 & 2.85 & 2.34 & 2.30 & 2.03 & 1.65 & & & & & 0.019 \\
\hline Pronionate & $\mathrm{ACOC}$ & 1.02 & 0.90 & 0.88 & 0.72 & 0.63 & 0.54 & 0059 & 0062 & 0001 & $<0001$ & 0640 \\
\hline riopionate & AEOC & 1.10 & 1.02 & 0.83 & 0.81 & 0.69 & 0.61 & 0.039 & 0.002 & 0.001 & 0.001 & 0.040 \\
\hline Butvrate & $\mathrm{ACOC}$ & 0.46 & 0.42 & 0.40 & 0.37 & 0.34 & 0.29 & 0043 & 0044 & 0005 & $<0001$ & 0891 \\
\hline Butyrate & AEOC & 0.50 & 0.48 & 0.41 & 0.39 & 0.36 & 0.32 & 0.043 & 0.044 & 0.005 & $<0.001$ & 0.891 \\
\hline Minor VFA 4 & $\mathrm{ACOC}$ & 0.17 & 0.18 & 0.18 & 0.19 & 0.18 & 0.16 & 0030 & 0030 & 0008 & 0117 & 0017 \\
\hline VIinor VFA & AEOC & 0.18 & 0.17 & 0.17 & 0.17 & 0.17 & 0.17 & $0.0<0$ & 0.020 & 0.008 & 0.111 & 0.011 \\
\hline Acetate/Propionate & $\mathrm{ACOC}$ & 2.83 & 2.87 & 2.86 & 2.92 & 3.07 & 2.61 & 0115 & 0125 & 0444 & 0151 & 0004 \\
\hline$(\mathrm{mol} / \mathrm{mol})$ & AEOC & 2.77 & 2.79 & 2.84 & 2.85 & 2.93 & 2.70 & & & & & \\
\hline $\mathrm{NH}_{2}-\mathrm{N}(\mathrm{mg} / \mathrm{l})$ & $\mathrm{ACOC}$ & 217 & 199 & 202 & 229 & 238 & 201 & 234 & 252 & 0002 & 0127 & 0812 \\
\hline $1013-19(111 \mathrm{~g} / 1)$ & AEOC & 170 & 178 & 180 & 165 & 199 & 206 & 25.4 & & & & \\
\hline
\end{tabular}

\footnotetext{
${ }^{1}$ ACOC, crude olive cake (samples AC1 to AC6); AEOC, exhausted olive cake (samples AE1 to AE6); ${ }^{2}$ standard error of the mean for processing effect; ${ }^{3}$ standard error of the mean for time effect. ${ }^{4}$ Calculated as the sum of isobutyrate, isovalerate and valerate.
} 
The fermentation parameters determined after "24 hr" incubation confirmed the negative effect of storage time on ruminal degradation of OC (Tables 8 and 9). Increasing storage time linearly increased $\mathrm{pH}$ values $(\mathrm{P}<0.001)$ and decreased gas and total VFA production $(\mathrm{P}<0.001)$ for both groups of samples. Total VFA production for 6-month stored OC samples was only 0.53 and 0.57 of that observed for crude and exhausted OC samples stored for 1 month, which is in accordance with the observed decreases in DMED. Acetate, propionate and butyrate productions were linearly decreased $(\mathrm{P}<0.001)$ with advancing time, with changes being similar for both crude and exhausted OC samples. The reduction in VFA production with advancing storage time was lower after 6 months than that observed during the first storage months, as acetate, propionate and butyrate productions for 8-month stored samples were $0.89,0.82$ and 0.95 of the productions for 6-month stored samples, respectively (values averaged across processing treatments). Acetate/propionate ratio remained relatively unchanged during the first five months of storage but showed the lowest value $(\mathrm{P}<0.001)$ at month 6 due to reduced acetate production. In contrast, acetate/propionate ratio increased linearly $(\mathrm{P}<0.001)$ from 6 to 8 storage months due to reductions in propionate proportions (21.6, 21.0 and 19.9/100 mol at 6, 7 and 8 months, respectively; averages for processing treatments), as acetate proportions remained unchanged over this period $(61.4,61.3$ and $61.4 / 100 \mathrm{~mol})$. Production of total and main individual VFA were negatively correlated $(\mathrm{P} \leq 0.033)$ with $\mathrm{NDF}, \mathrm{ADF}$ and $\mathrm{ADF}$ contents and positively correlated $(\mathrm{P} \leq 0.002)$ with sugars content, reflecting the lower fermentability of fibre fractions compared with sugars. The observed trend $(\mathrm{P}=0.080)$ to a positive correlation between $\mathrm{N}$ content and minor VFA production possibly reflects the deamination of branched amino acids which produces isobutyrate, valerate and isovalerate (Wallace and Cotta, 1988), as the incubation medium only contained non-protein N.

There was no effect of storage time $(\mathrm{P} \geq 0.127)$ on $\mathrm{NH}_{3}-\mathrm{N}$ concentrations for any group of samples. Although most samples had low $\mathrm{N}$ content, the use of an Nenriched medium explains that $\mathrm{NH}_{3}-\mathrm{N}$ concentrations were always above the level limiting in vitro ruminal microbial growth (Satter and Slyter, 1974). 
Table 9. Effect of processing (PR) and storage time in the pond (Time) of olive cake (OC) samples on fermentation parameters in 24-hr in vitro ruminal fermentation.

\begin{tabular}{|c|c|c|c|c|c|c|c|c|}
\hline \multirow{2}{*}{ Item } & \multirow{2}{*}{$\mathbf{P R}^{1}$} & \multicolumn{3}{|c|}{ Storage time (months) } & \multirow{2}{*}{$\operatorname{SEM}_{\mathrm{PR}}^{2}$} & \multirow{2}{*}{$\operatorname{SEM}_{\text {Time }}{ }^{3}$} & \multicolumn{2}{|c|}{ P-value } \\
\hline & & 6 & 7 & 8 & & & $\mathbf{P R}$ & Time $^{\mathrm{a}}$ \\
\hline \multirow{4}{*}{ Gas (ml/g dry matter (DM)) } & $\mathrm{BCOC}^{\mathrm{a}}$ & 51.5 & 40.5 & 38.0 & & & & \\
\hline & $\mathrm{BEOC}^{\mathrm{a}}$ & 49.0 & 42.5 & 39.5 & 1.70 & 1.57 & 0.001 & $<0.001$ \\
\hline & $\mathrm{BCYO}^{\mathrm{b}}$ & 51.5 & 40.5 & 38.0 & & & & \\
\hline & $\mathrm{BCOC}^{\mathrm{ab}}$ & 7.03 & 7.09 & 7.10 & & & & \\
\hline \multirow[t]{2}{*}{$\mathrm{pH}$} & $\mathrm{BEOC}^{\mathrm{b}}$ & 7.06 & 7.09 & 7.11 & 0.017 & 0.017 & 0.011 & $<0.001$ \\
\hline & $\mathrm{BCYO}^{\mathrm{a}}$ & 7.00 & 7.02 & 7.09 & & & & \\
\hline \multicolumn{9}{|l|}{ Volatile fatty acids (VFA; mmol/g DM) } \\
\hline & $\mathrm{BCOC}^{\mathrm{a}}$ & 3.28 & 2.95 & 2.90 & & & & \\
\hline \multirow[t]{3}{*}{ Total } & $\mathrm{BEOC}^{\mathrm{a}}$ & 3.28 & 3.17 & 3.00 & 0.219 & 0.219 & $<0.001$ & $<0.001$ \\
\hline & $\mathrm{BCYO}^{\mathrm{b}}$ & 3.55 & 3.69 & 3.11 & & & & \\
\hline & $\mathrm{BCOC}^{\mathrm{a}}$ & 2.01 & 1.81 & 1.78 & & & & \\
\hline \multirow[t]{3}{*}{ Acetate } & $\mathrm{BEOC}^{\mathrm{a}}$ & 2.01 & 1.96 & 1.85 & 0.129 & 0.129 & $<0.001$ & $<0.001$ \\
\hline & $\mathrm{BCYO}^{\mathrm{b}}$ & 2.19 & 2.25 & 1.90 & & & & \\
\hline & $\mathrm{BCOC}^{\mathrm{a}}$ & 0.71 & 0.61 & 0.58 & & & & \\
\hline \multirow[t]{3}{*}{ Propionate } & $\mathrm{BEOC}^{\mathrm{a}}$ & 0.70 & 0.65 & 0.58 & 0.035 & 0.035 & $<0.001$ & $<0.001$ \\
\hline & $\mathrm{BCYO}^{\mathrm{b}}$ & 0.78 & 0.82 & 0.64 & & & & \\
\hline & $\mathrm{BCOC}^{\mathrm{a}}$ & 0.38 & 0.35 & 0.35 & & & & \\
\hline \multirow[t]{3}{*}{ Butyrate } & $\mathrm{BEOC}^{\mathrm{a}}$ & 0.38 & 0.37 & 0.36 & 0.047 & 0.047 & 0.003 & 0.069 \\
\hline & $\mathrm{BCYO}^{\mathrm{b}}$ & 0.39 & 0.41 & 0.38 & & & & \\
\hline & $\mathrm{BCOC}^{\mathrm{a}}$ & 0.19 & 0.18 & 0.19 & & & & \\
\hline \multirow{3}{*}{ Minor VFA ${ }^{4}$} & $\mathrm{BEOC}^{\mathrm{b}}$ & 0.19 & 0.20 & 0.20 & 0.022 & 0.022 & 0.002 & 0.043 \\
\hline & $\mathrm{BCYO}^{\mathrm{b}}$ & 0.19 & 0.20 & 0.20 & & & & \\
\hline & $\mathrm{BCOC}^{\mathrm{b}}$ & 2.82 & 2.99 & 3.10 & & & & \\
\hline \multirow[t]{3}{*}{ Acetate/Propionate $(\mathrm{mol} / \mathrm{mol})$} & $\mathrm{BEOC}^{\mathrm{b}}$ & 2.89 & 3.03 & 3.19 & 0.140 & 0.140 & $<0.001$ & $<0.001$ \\
\hline & $\mathrm{BCYO}^{\mathrm{a}}$ & 2.80 & 2.74 & 2.97 & & & & \\
\hline & $\mathrm{BCOC}$ & 249 & 197 & 217 & & & & \\
\hline \multirow[t]{2}{*}{ NH3-N (mg/l) } & BEOC & 199 & 262 & 228 & 26.8 & 26.8 & 0.787 & 0.671 \\
\hline & BCYO & 234 & 249 & 215 & & & & \\
\hline
\end{tabular}

${ }^{\mathrm{T}}$ BCOC, crude olive cake (samples BCOC6 to BCOC8); BCYOC, obtained from a cyclone separator after drying the OC (samples BCYOC6 to BCYOC8); BEOC, exhausted olive cake (samples BEOC6 to BEOC8); ${ }^{2}$ standard error of the mean for processing effect; ${ }^{3}$ standard error of the mean for time effect.

Calculated as the sum of isobutyrate, isovalerate and valerate. ${ }^{\mathrm{a}-\mathrm{b}}$ Within each parameter, different superscripts indicate differences among treatments $(\mathrm{P}<0.05)$. 
III.3.3. Effects of processing treatment on in vitro fermentation of olive cake

In the first group of OC samples, all gas production parameters excepting Lag were greater $(\mathrm{P} \leq 0.018)$ in exhausted compared with crude $\mathrm{OC}$ samples (Table 6). This was attributed to the high EE content of crude OC samples, as unsaturated fatty acids resulting from the triglyceride hydrolysis are toxic to many ruminal bacteria, but especially for fibrolytic bacteria (Maia et al., 2007). All exhausted OC samples had EE contents below the maximal level of $60 \mathrm{~g} / \mathrm{kg}$ DM usually recommended to avoid reductions in fibre digestibility (National Research Council, 2001), but EE content was greater in all crude OC samples ( $\geq 86 \mathrm{~g} / \mathrm{kg} \mathrm{DM})$. Similarly, for OC samples stored from 6 to 8 months values of $c$ and AGPR were greater $(\mathrm{P} \leq 0.013)$ for exhausted than for crude OC samples, with no differences $(\mathrm{P}>0.05)$ in PGP and Lag (Table 7). Cyclone OC samples had greater $(\mathrm{P}<0.001)$ PGP and DMED than both crude and exhausted OC samples, which is consistent with the lower NDF content of cyclone OC samples (Table 4). The greater $(\mathrm{P}<0.001)$ values of DMED and VFA production of cyclone OC samples compared with both crude and exhausted OC samples would indicate that the high EE content of cyclone OC samples ( $\geq 148 \mathrm{~g} / \mathrm{kg} \mathrm{DM})$ did not negatively affect their ruminal fermentation. Although fatty acid profile of OC samples was not measured, it is possible that fat composition changed during storage due to oxidation and microbial activity (Ramos-Hinojosa and Ruiz-Méndez, 2004) and the resulting fatty acids would be less toxic to ruminal microorganisms. The lack of differences in DMED between crude and exhausted OC samples taken at 6,7 and 8 storage months is in agreement with the similar DMED values observed for crude and exhausted OC samples taken at 5 and 6 months of storage (Tables 6 and 7). These results indicate that differences in the nutritive value between crude and exhausted OC are reduced as storage time advanced.

In conclusion, the nutritive value of olive cake was reduced with advancing storage time and values of ruminal degradability at 6-months storage decreased by 0.64 and 0.54 of values measured after one-month storage for crude and exhausted olive cake samples, respectively. This was mainly due to the loss of the easily fermentable fractions produced during storage, but the results indicate that there were only subtle changes in OC samples during the first two months of storage. Exhausted OC samples showed greater ruminal degradability values than crude OC samples over the first five 
months of storage, but differences disappeared from 6 months storage. Ruminal degradability of cyclone OC samples was 1.3 times greater than that of crude and exhausted OC samples obtained at the same storage time.

\section{ACKNOWLEDGMENTS}

Funding from the Spanish Ministry of Economy and Competitiveness (AGL201675322-C2-1-R and AGL2014-56653-C3-1-R) is gratefully acknowledged. Authors are grateful to SACYR S.A. for providing the olive cake samples used in this study.

\section{References}

Alburquerque, J. A., Gonzálvez, J., García, D., and Cegarra, J. (2004). Agrochemical characterization of "alperujo", a solid by-products of the two-phase centrifugation method for olive oil extraction. Bioresource Technology 91, 195-200.

Alburquerque, J. A., Gonzálvez, J., García, D., and Cegarra, J. (2006). Measuring detoxification and maturity in compost made from "alperujo", the solid by-products of extracting olive oil by the two- phase centrifugation system. Chemosphere 64, 470477.

Alhamad, M. N., Rababah, T. M., Al-u'datt, M., Ereifej, K., Esoh, R., Feng, H., and Yang, W. (2017). The physicochemical properties, total phenolic, antioxidant activities, and phenolic profile of fermented olive cake. Arabian Journal of Chemistry 10, 136-140.

Association of Official Analytical Chemists (AOAC). (2005). Official Methods of Analysis, 18th ed. AOAC International.

Callejo, J. A., Parra, T., and Manrique, T. (2015). Evaluación de la producción y usos de los subproductos de las agroindustrias del olivar en Andalucía (1st ed.). Consejería de Agricultura, Pesca y Desarrollo Rural de la Junta de Andalucía.

Consejo Oleícola Internacional. (2018). Olive oil performance in 2017/18 and olive oil and table olive estimates 2018/19. Market Newsletter $N^{0} 130$. [consulted 05/04/2019]. Available in: $\quad$ www.internationaloliveoil.org/.../14007-market-newsleteerseptember.pdf.

Dermeche, S., Nadour, M., Larroche, C., Moulti-Mati, F., and Michaud, P. (2013). Olive mill wastes: Biochemical characterizations and valorization strategies. Process 
Biochemistry 48, 1532-1552.

France, J., Dijkstra, J., Dhanoa, M. S., López, S., and Bannink, A. (2000). Estimating the extent of degradation of ruminant feeds from a description of their gas production profiles observed in vitro: Derivation of models and other mathematical considerations. British Journal of Nutrition 83, 131-142.

García-Martínez, R., Ranilla, M. J., Tejido, M. L., and Carro, M. D. (2005). Effects of disodium fumarate on in vitro rumen microbial growth, methane production and fermentation of diets differing in their forage concentrate ratio. British Journal of Nutrition 94, 71-77.

Goering, M. K., and Van Soest, P. J. (1970). Forage Fiber Analysis (Apparatus, Reagents, Procedures and Some Applications). In "Agricultural Handbook; Agriculture Handbook No. 379”. Agricultural Research Services.

Greco, G., Toscanoa, G., Cioffi, M., Gianfreda, L., and Sannino, F. (1999). Dephenolisation of olive mill waste-water by olive husk. Water Research 33, 30463050 .

Maia, M. R., Chaudhary, L. C., Figueres, L., and Wallace, R. J. (2007). Metabolism of polyunsaturated fatty acids and their toxicity to the microflora of the rumen. Antonie Van Leeuwenhoek 91, 303-314.

MAPA. (2018). Ministerio de Agricultura, Pesca y Alimentación. Available in: http://www.mapa.gob.es/

Martínez, N. L., Garrido, H. S. E., Camacho, R. F., García, P. M. P., and Ramos, C. A. (1993). The biological purification of waste products from olive oil extraction. Bioresource Technology 43, 215-219.

Molina-Alcaide, E., Carro, M. D., Rodela, M., Weisbjerg, M. R., Lind, V., and NovoaGarrido, M. (2017). In vitro ruminal fermentation and methane production of different seaweed species. Animal Feed Science and Technology 228, 1-12.

Molina-Alcaide, E., and Nefzaoui, A. (1996). Recycling of olive oil by- products: Possibilities of utilization in animal nutrition. International Biodeterioration \& Biodegradation 38, 227-235.

Molina-Alcaide, E., and Yáñez-Ruiz, D. R. (2008). Potential use of olive by-products in ruminant feeding: a review. Animal Feed Science and Technology 147, 247-264. 
NRC (National Research Council). (2001). Nutrient Requirements of Dairy Cattle, 7th ed. National Academy of Sciences.

Piquer, O., Casado, C., Biglia, S., Fernández, C., Blas, E., and Pascual, J. J. (2009). In vitro gas production kinetics of whole citrus fruits. Journal of Animal Feed Science 18, 743-757.

Ramos-Hinojosa, A. E., and Ruiz-Méndez, M. V. (2004). Two-phases olive pomace storaged in ponds. Grasas Y Aceites 55, 251-258.

Robertson, J. B., and Van Soest, P. J. The detergent system of analysis and its application to human foods. New York, USA, ed. James, W. P. T., Theander, O. 1981. In "The Analysis of Dietary Fiber in Food". pp. 123-142. Marcel Dekker.

Satter, L. D., and Slyter, L. L. (1974). Effect of ammonia concentration on rumen microbial protein production in vitro. British Journal of Nutrition 32, 199-208. 


\title{
Chapter IV. VARIABILITY IN THE
}

\section{CHEMICAL COMPOSITION AND}

\author{
IN VITRO RUMINAL \\ FERMENTATION OF OLIVE \\ CAKE BY-PRODUCTS
}

Marcos, C. N., García-Rebollar, P., De Blas, C., and Carro, M. D. (2019). Variability in the Chemical Composition and In Vitro Ruminal Fermentation of Olive Cake By-Products. Animals 9, 109-120. doi: 10.3390/ani9030109

ISI Journal Citation Reports Ranking 2018: Animals was ranked 11 out of 61 Journals in the area of "Agriculture, Dairy \& Animal Science" 
Simple Summary: Olive cake is a by-product of oil production that can be used in ruminant feeding, but its composition can vary with multiple factors. The objective of this study was to determine the variability in the chemical composition and in vitro ruminal fermentation of 42 olive cake samples to evaluate their nutritive value for ruminants. The results showed that the chemical composition of olive cake is highly variable and is markedly affected by processing type and its storage time before processing. Cyclone olive cake had greater nutritive value for ruminants than both crude and exhausted olive cake. All olive cake types were poorly degraded in vitro and, therefore, their nutritive value is highly dependent on their ether extract content. Statistical models using olive cake processing type, and either the chemical composition or storage time before processing as covariates, can be used in the practice to predict in vitro ruminal fermentation variables of olive cake samples. The obtained information may contribute to increase the use of olive cake in ruminant feeding.

Abstract: The objective of this study was to determine the variability in the chemical composition and in vitro ruminal fermentation of olive cake (OC) by-products. Fortytwo OC samples with different storage times (1-14 months) and processing (25 crude (COC), 9 exhausted (EOC) and 9 cyclone (CYOC)) were fermented in vitro with sheep ruminal fluid. Exhausted OC samples had a lower ether extract content than COC and CYOC (15.9, 110 and $157 \mathrm{~g} / \mathrm{kg}$ dry matter (DM), respectively), but greater neutral detergent fiber (NDF; 645, 570 and $441 \mathrm{~g} / \mathrm{kg}$ DM) and acid insoluble nitrogen (9.76, 8.10 and $8.05 \mathrm{~g} / \mathrm{kg} \mathrm{DM})$ content. Exhausted $\mathrm{OC}$ had the greatest $(\mathrm{P}<0.05)$ average gas production rate (AGPR), whereas the greatest fermented organic matter (FOM) was obtained for EOC and CYOC. The best single predictor of the AGPR was total sugars content $\left(\mathrm{R}^{2}=0.898\right)$, whereas NDF was the best one for FOM $\left(\mathrm{R}^{2}=0.767 ; \mathrm{P}<0.001\right)$. Statistical models using storage time as a predictor variable had lower accuracy and $\mathrm{R}^{2}$ values than those from the chemical composition. In summary, the nutritive value of OC was highly dependent on its processing, but its ether extract content did not negatively affect ruminal fermentation parameters, which could be estimated from either carbohydrate composition or storage time.

Keywords: olive cake; storage time; processing; in vitro ruminal fermentation; prediction models 


\section{IV.1. Introduction}

The use of agroindustrial by-products in animal feeding is increasing worldwide, as it is a viable solution to value wastes and minimize environmental pollution from food industries (Romero-Huelva et al., 2017). However, the chemical composition of these ingredients is highly variable and frequently only limited data on their nutritive value are available, thus limiting their use as regular ingredients in animal rations.

The Mediterranean area concentrates most of world olive oil production, with Spain being the world's leading producer (FAO, 2018). The system of olive oil extraction most widely used in Spain generates a wet solid-waste (500-700 g moisture/kg) called "alperujo", which is stored in open-air ponds before being processed to obtain different types of olive cake (OC). After removal of olive stones, the alperujo is dried to produce crude olive cake (COC), which can be treated with solvents to extract the residual oil (pomace olive oil), obtaining the exhausted olive cake (EOC). In order to clean the air used to dry the alperujo before being emitted to the atmosphere, the OC particles floating in the air are collected from cyclone decanters generating cyclone OC (CYOC). Crude OC is the by-product more frequently used for ruminant feeding, whereas EOC is mostly used as biomass fuel for electricity generation, and small amounts of CYOC are marketed as high-quality COC. The chemical composition of OC by-products can be influenced by multiple factors such as the olive cultivar, the ripeness of the fruit, the alperujo storage conditions and the processing techniques (Dermeche et al., 2013; Molina-Alcaide y Yáñez-Ruiz, 2008). The amount of data on the chemical composition of different types of OC is variable (Heuzé et al., 2015), but to the best of our knowledge there is no information on the composition of CYOC. Moreover, the existing information on the dry matter ruminal degradability of OC is scarce, although available data indicate low values with a wide range of variation (from $8 \%$ to $42 \%$ ) (Molina-Alcaide y Yáñez-Ruiz, 2008). Therefore, the first objective of this study was to analyse the variability in the chemical composition and in vitro ruminal fermentation of different types of OC to evaluate their potential nutritive value for ruminants. A previous study (Marcos et al., 2019) showed a marked influence of the storage time of the alperujo on the chemical composition and in vitro fermentation of OC and, therefore, samples of OC stored for different times were obtained at various extraction plants. The samples used in the study of Marcos et al. (2019) were included 
in the present study to increase the sample size. In addition, statistical models were developed to estimate the fermentation characteristics of OC from processing type and either the chemical composition or storage time of the alperujo in the ponds.

\section{IV.2. Materials and methods}

\section{IV.2.1. Olive cake samples}

In order to obtain OC samples representative of those available in Spain for animal feeding, a total of 42 samples of OC were obtained at nine different extraction plants located in the South of Spain during the 2015/16 and 2016/17 olive oil campaigns. Samples were classified according to processing type (COC, EOC and CYOC) and storage time in the open-air ponds (from 1 to 14 months). Twenty-five samples of COC were obtained by drying the alperujo and all of them were pelleted, whereas 9 EOC samples were generated by subjecting the dried alperujo to oil extraction using hexane and drying the exhausted cake, and 8 CYOC samples came from the particles collected from the air in cyclone decanters during the alperujo drying process. Processing of all OC samples were performed at the extraction plants using the habitual procedures in each of them. Storage time of the alperujo in the ponds was 3 months or lower for 10 samples (4 COC, 3 EOC and 3 CYOC), between 4 and 6 months for 16 samples (11 COC, $3 \mathrm{EOC}$ and $2 \mathrm{CYOC}$ ), and 7 months or longer for 16 samples (10 COC, 2 EOC and 4 CYOC. All samples were ground to pass a $1 \mathrm{~mm}$ screen before chemical analyses and in vitro incubations.

\section{IV.2.2. In vitro incubations}

All procedures involving animals were approved by the Institutional Animal Care and Use Committee of the Comunidad Autónoma de Madrid (PROEX 035/17). Four Lacaune sheep $(64.7 \pm 2.10 \mathrm{~kg}$ body weight), each provided with a permanent cannula in the rumen, were used as donors of ruminal fluid for the in vitro incubations. Sheep were individually housed, had access to fresh water over the trial, and were fed a diet composed of grass hay and concentrate in a 2:1 ratio at a rate of $45 \mathrm{~g}$ dry matter $(\mathrm{DM}) / \mathrm{kg}$ body weight ${ }^{0.75}$. Diet was fed in two equal meals at 08:00 and 18:00 $\mathrm{h}$. The diet contained 112, 350 and $166 \mathrm{~g}$ of crude protein, neutral detergent fiber (NDF) and acid detergent fiber (ADF) per kg DM, respectively. 
Two in vitro trials were conducted in different days using the same methodology to determine gas production kinetics and the main ruminal fermentation parameters, respectively. In each incubation trial, four replicates per OC sample were obtained by conducting the incubations on four different days and each day the ruminal fluid from one sheep was used as the inoculum. Ruminal contents of each sheep were obtained before the morning feeding, strained through four layers of cheesecloth and immediately transported to the laboratory in thermal flasks. The fluid was mixed with the culture medium (Goering and Van Soest, 1970) (without trypticase; $39^{\circ} \mathrm{C}$ ) in a 1:4 ratio under $\mathrm{CO}_{2}$ flushing. Samples (200 mg of DM) of each OC were weighed into $60-\mathrm{mL}$ vials before the addition of $20 \mathrm{~mL}$ of the mixture of ruminal fluid and culture medium. Vials were then sealed with rubber stoppers and incubated at $39{ }^{\circ} \mathrm{C}$. In the first trial, to determine gas production kinetics, vials were incubated for $120 \mathrm{~h}$, and gas production was measured at $3,6,9,12,15,22,26,31,36,48,58,72,96$ and $120 \mathrm{~h}$ using a pressure transducer (Widereager Wide Range Pressure Meter, Sper Scientific LTD, Scottsdale, AZ, USA) and a plastic syringe. The gas produced at each measurement time was released to prevent gas accumulation. Blanks (vials without a sample; two per inoculum) were also incubated to correct values of gas production for endogenous gas production. The second incubation trial was conducted to analyze the main fermentation parameters after $24 \mathrm{~h}$ of incubation. Gas production was measured as described before. Vials were then uncapped, their content was homogenized and the $\mathrm{pH}$ was measured using a Crison Basic $20 \mathrm{pH}$ meter (Crison Instruments, Barcelona, Spain). For determining volatile fatty acid (VFA) and $\mathrm{NH}_{3}-\mathrm{N}$ concentrations, $3 \mathrm{~mL}$ of the content of each vial was mixed with $3 \mathrm{~mL}$ of $\mathrm{HCl} 0.5 \mathrm{~N}$, and samples were stored at $-20{ }^{\circ} \mathrm{C}$ until analyses.

In order to calculate DM effective degradability (DMED), the potential in vitro DM degradability (DMD120) was determined by weighing, in triplicate, $300 \mathrm{mg}$ of each OC sample into polyester bags $(30-\mu \mathrm{m}$ pore size; Ankom Corp \#57, Ankom Technology Corp., Fairport, NY, USA). Bags were incubated with a 1:4 ratio of ruminal fluid (mixture of the fluid from the 4 sheep) to incubation medium (Goering and Van Soest, 1970) in an Ankom Daisy II incubator (Ankom Technology Corp., Fairport, NY, USA) at $39^{\circ} \mathrm{C}$ and under continuous rotation. After $120 \mathrm{~h}$, bags were washed with cold water, dried at $60{ }^{\circ} \mathrm{C}$ for $48 \mathrm{~h}$, and weighted to calculate DMD120. 


\section{IV.2.3. Chemical analyses}

The proximate composition of OC samples was analyzed using the procedures of the Association of Official Agricultural Chemists (AOAC, 2005) for dry matter (ID 934.01), ash (ID 048.13) and ether extract (EE; ID 945.16). Concentrations of NDF, $\mathrm{ADF}$ and acid detergent lignin (ADL) were determined following the procedures of Van Soest et al. (1991) and Robertson and Van Soest (1981), respectively, using an ANKOM220 Fiber Analyzer unit (ANKOM Technology Corporation, Fairport, NY, USA). Sodium sulphite was used in the sequential analysis of NDF, ADF and ADL, and results were expressed exclusive of residual ash. Nitrogen was measured by the Dumas combustion method employing a Leco FP258 Nitrogen Analyzer (Leco Corporation, St. Joseph, MI, USA). Acid detergent insoluble nitrogen (ADIN) was determined by analyzing the $\mathrm{N}$ content in the residue obtained after treatment with acid detergent solution. Total sugars and total soluble polyphenols (TSP) were analyzed by colorimetric methods following the anthrone method (Yemm and Willis, 1954) and the Folin-Ciocalteu assay (Singleton and Rossi, 1965), respectively, using an Epoch spectrophotometer (BioTek Instruents Inc., Winooski, VT, USA).

Concentrations of $\mathrm{NH}_{3}-\mathrm{N}$ in vial contents after $24 \mathrm{~h}$ of fermentation were determined by the phenol-hypochlorite method as described by Weatherburn (1967), and those of VFA were conducted by gas chromatography as described by GarcíaMartínez et al. (2005). All analyses were performed in duplicate.

IV.2.4. Calculations and statistical analyses

Data of gas production were fitted with time using the model: Gas = PGP $(1-\mathrm{e}$ $\left(\left(^{-c(t-l a g))}\right)\right.$, where PGP is the potential gas production $(\mathrm{mL}), \mathrm{c}$ is the fractional rate of gas production ( $\mathrm{h}-1)$, lag is the initial delay in the onset of gas production $(\mathrm{h})$, and $\mathrm{t}$ is the time of gas measurement. Gas production parameters were estimated using the NLIN procedure of SAS (SAS, 2017) by an iterative least squares procedure. The average gas production rate (AGPR; $\mathrm{mL}$ gas $/ \mathrm{h}$ ) was defined as the average gas production rate between the start of the incubation and the time when half of the PGP was reached, and was calculated as AGPR $=$ PGP $c /[2(\ln 2+c$ lag $)]$. The DMED was estimated for a rumen particulate outflow $(K \mathrm{p})$ of 0.042 per $\mathrm{h}$ from gas production parameters and $\mathrm{DMD}_{120}$ as: $\mathrm{DMED}=\left[\left(\mathrm{DMD}_{120} \times c\right) /(c+K \mathrm{p})\right] \mathrm{e}^{(-c \times l a g)}$. This rumen 
particulate outflow corresponds to a rumen retention time of $24 \mathrm{~h}$. Finally, the amount of fermented organic matter (FOM) was calculated from acetate, propionate and butyrate production in each vial as described by Demeyer (1991).

The chemical composition data of OC samples was analyzed using the PROC GLM of SAS (SAS, 2017) with OC type as the main effect. Data on fermentation parameters were analyzed as a mixed model using the PROC MIXED of SAS (SAS, 2017), where the effect of OC type (COC, EOC and CYOC) was considered fixed and inoculum was considered a random effect. In both models, when effects were significant, means were compared by using the Tukey's test. Pearson correlation coefficients among the chemical composition of OC samples, gas production or fermentation parameters, and storage time of the alperujo were assessed using the PROC CORR of SAS (SAS, 2017). Models to predict the AGPR and FOM were developed using the PROC GLM of SAS, including OC type (COC, EOC and CYOC) as the fixed effect and chemical fractions as linear and quadratic covariates. The interaction between OC type and the chemical composition was also studied. Slopes of the models for different OC types were compared by Student's test. In addition, the accuracy of predicting the AGPR and FOM from OC type and the duration (months) of the alperujo storage in ponds as a covariate was evaluated using the same model.

\section{IV.3. Results}

IV.3.1. Influence of olive cake processing type on chemical composition and in vitro fermentation

The chemical composition of OC samples (Table 10) was highly variable. There were great differences in EE content (coefficient of variation (CV) of 53\%), but TSP and sugars were the most variable fractions, with CV values ranging from $44.1 \%$ to $126 \%$. For each of the three OC types, the most variable fractions were also sugars $(\mathrm{CV} \geq 107 \%)$ and TSP $(\mathrm{CV} \geq 41.1 \%)$, whereas $\mathrm{CV}$ values for the rest of the chemical fractions were lower than $24 \%$, with the exception of EE for EOC (69.7\%). Crude OC and EOC groups showed similar CV values for most components analyzed, and CYOC had greater $\mathrm{CV}$ values for $\mathrm{ADL}$ and $\mathrm{ADIN}$ compared to COC and EOC.

As shown in Table 11, CYOC had greater $(\mathrm{P}<0.05) \mathrm{DM}, \mathrm{N}$ and EE content 
than COC, but lower organic matter (OM), NDF, ADF and ADL content. Compared with COC, EOC had lower EE but greater NDF, ADIN and TSP content. Total sugars were the only fraction analyzed in which no differences among OC types were observed.

Samples of COC had lower $(\mathrm{P}<0.05)$ PGP, AGPR and DMED values than EOC, whereas CYOC showed intermediate values of PGP and DMED (Table 12). After $24 \mathrm{~h}$ of incubation, neither total VFA production nor molar proportions of individual VFA differed among OC types, with the exception of minor VFA proportions that were lower $(\mathrm{P}=0.003)$ for EOC compared with COC samples. Samples of EOC also had lower $\mathrm{NH}_{3}-\mathrm{N}$ concentrations than both $\mathrm{COC}$ and CYOC. Calculated FOM values were greater for EOC and CYOC samples than for COC.

\section{IV.3.2. Estimation of fermentation parameters}

The average gas production rate and FOM were selected for developing prediction models as they reflect the fermentation rate and extent of rumen fermentation, respectively. Table 13 shows the correlation coefficients between the chemical composition, fermentation parameters (AGPR and FOM) and storage time of the alperujo. Sugars and TSP were the chemical fractions more closely correlated with the AGPR ( $r=0.90$ and 0.69 , respectively; $\mathrm{P}<0.001$ ), whereas NDF, total sugars and TSP content were highly correlated $(\mathrm{r}=-0.68,0.82$ and 0.78 , respectively; $\mathrm{P}<0.001)$ with FOM. Storage time showed negative correlations $(\mathrm{r} \geq-0.74 ; \mathrm{P}<0.001)$ with total sugars and TSP content, and both fermentation parameters. 
Table 10. Chemical composition ( $\mathrm{g} / \mathrm{kg}$ dry matter unless stated otherwise) of olive cake (OC) samples $(n=42)$.

\begin{tabular}{|c|c|c|c|c|c|}
\hline \multirow{2}{*}{ Item } & \multirow{2}{*}{ Mean } & \multirow{2}{*}{$\mathbf{C V}$} & \multicolumn{3}{|c|}{ OC Type (Range of Values and CV) $^{1}$} \\
\hline & & & Crude OC $(n=25)$ & Exhausted OC $(n=9)$ & Cyclone OC $(n=8)$ \\
\hline Dry matter (g/kg) & 906 & 2.77 & $862-946[2.49]$ & $860-908[1.95]$ & $914-952[1.43]$ \\
\hline Organic matter & 913 & 1.98 & $873-948[2.03]$ & $894-935[1.38]$ & $885-910[0.91]$ \\
\hline Neutral detergent fiber & 561 & 17.8 & $402-721[13.4]$ & $528-766[14.0]$ & $367-528[13.5]$ \\
\hline Acid detergent fiber & 409 & 17.2 & $298-501[12.6]$ & $385-533[12.2]$ & $256-374[13.5]$ \\
\hline Acid detergent lignin & 201 & 14.6 & $170-250[10.0]$ & $197-261[9.41]$ & $123-190[15.4]$ \\
\hline Nitrogen $(\mathrm{N})$ & 16.7 & 14.1 & $13.1-18.6[10.7]$ & $15.8-23.5[13.0]$ & $12.5-22.2[17.5]$ \\
\hline Acid detergent insoluble $\mathrm{N}$ & 8.45 & 19.8 & $5.20-11.9[18.4]$ & $7.85-12.2[14.4]$ & $4.70-10.8[23.9]$ \\
\hline Ether extract & 99 & 53.1 & $73.3-145[21.3]$ & $4.00-32.0[69.7]$ & $108-195[20.0]$ \\
\hline Total sugars & 43.2 & 123 & $7.10-202[126]$ & $8.00-197[107]$ & $6.50-149[120]$ \\
\hline Total soluble polyphenols & 14.5 & 44.8 & $5.30-29.1[42.0]$ & $8.60-29.2[41.1]$ & $9.70-29.2[41.9]$ \\
\hline
\end{tabular}

${ }^{\top}$ Minimum and maximum values and coefficients of variation (CV; \%). Crude OC: samples were dried and pelletized; Exhausted OC: samples were dried and subjected to a second oil extraction using hexane; Cyclone OC: samples were obtained from cyclone decanters during drying COC. $n=$ number of samples.

Values between brackets are CV (\%). 
Table 11. Influence of olive cake (OC) processing on chemical composition ( $\mathrm{g} / \mathrm{kg}$ dry matter unless stated otherwise).

\begin{tabular}{|c|c|c|c|c|c|}
\hline \multirow{2}{*}{ Item } & \multicolumn{3}{|c|}{ OC Type $^{1}$} & \multirow{2}{*}{ SEM $^{2}$} & \multirow{2}{*}{ P-Value } \\
\hline & Crude OC $(n=25)$ & Exhausted OC $(n=9)$ & Cyclone OC $(n=8)$ & & \\
\hline Dry matter (g/kg) & $904^{\mathrm{a}}$ & $886^{\mathrm{a}}$ & $934^{\mathrm{b}}$ & 6.1 & $<0.001$ \\
\hline Organic matter & $916^{b}$ & $919^{b}$ & $895^{\mathrm{a}}$ & 4.9 & 0.004 \\
\hline Neutral detergent fiber & $570^{b}$ & $645^{c}$ & $441^{\mathrm{a}}$ & 23.4 & $<0.001$ \\
\hline Acid detergent fiber & $409^{b}$ & $454^{\mathrm{b}}$ & $309^{\mathrm{a}}$ & 15.4 & $<0.001$ \\
\hline Acid detergent lignin & $205^{b}$ & $225^{b}$ & $163^{\mathrm{a}}$ & 6.5 & $<0.001$ \\
\hline Nitrogen $(\mathrm{N})$ & $15.8^{\mathrm{a}}$ & $17.8^{\mathrm{b}}$ & $18.0^{\mathrm{b}}$ & 0.65 & 0.013 \\
\hline Acid detergent insoluble $\mathrm{N}$ & $8.10^{\mathrm{a}}$ & $9.76^{b}$ & $8.05^{\mathrm{a}}$ & 0.473 & 0.025 \\
\hline Ether extract ${ }^{3}$ & $110^{\mathrm{b}}$ & $15.9^{\mathrm{a}}$ & $157^{\mathrm{c}}$ & 7.35 & $<0.001$ \\
\hline Total sugars $^{3}$ & 33.9 & 57.8 & 43.9 & 11.0 & 0.244 \\
\hline Total soluble polyphenols ${ }^{3}$ & $12.4^{\mathrm{a}}$ & $18.4^{\mathrm{b}}$ & $16.7^{\mathrm{ab}}$ & 1.93 & 0.031 \\
\hline
\end{tabular}

${ }^{a, b}$ Within each chemical fraction, mean values with different superscripts differ $(\mathrm{P}<0.05) .{ }^{1}$ Crude OC: samples were dried and pelletized; Exhausted OC: samples were dried and subjected to a second oil extraction using hexane; Cyclone OC: samples were obtained from cyclone decanters during drying COC. $n=$ number of samples. ${ }^{2} \mathrm{SEM}=$ Standard error of the mean. ${ }^{3}$ the Kruskal-Wallis test was used to compare these variables, as they were not normally distributed. 
Table 12. Influence of olive cake (OC) processing on gas production parameters, dry matter effective degradability (DMED) and fermentation parameters in a $24 \mathrm{~h}$ in vitro fermentation of OC samples.

\begin{tabular}{|c|c|c|c|c|c|}
\hline \multirow{2}{*}{ Item } & \multicolumn{3}{|c|}{ OC Type $^{1}$} & \multirow{2}{*}{ SEM $^{2}$} & \multirow{2}{*}{ P-Value } \\
\hline & Crude OC $(n=25)$ & Exhausted OC $(n=9)$ & Cyclone OC $(n=8)$ & & \\
\hline \multicolumn{6}{|l|}{ Gas production parameters $^{2}$} \\
\hline PGP (mL/g dry matter) & $64.5^{\mathrm{a}}$ & $78.1^{\mathrm{b}}$ & $74.4^{\mathrm{ab}}$ & 3.67 & 0.008 \\
\hline$c(\mathrm{~h}-1)$ & $0.048^{\mathrm{b}}$ & $0.054^{\mathrm{b}}$ & $0.040^{\mathrm{a}}$ & 0.0022 & $<0.001$ \\
\hline $\operatorname{Lag}(\mathrm{h})$ & 0.16 & 0.21 & 0.33 & 0.091 & 0.208 \\
\hline $\operatorname{AGPR}(\mathrm{mL} / \mathrm{h})$ & $2.23^{\mathrm{a}}$ & $3.07^{\mathrm{b}}$ & $2.13^{\mathrm{a}}$ & 0.182 & $<0.001$ \\
\hline DMED (g/kg DM) & $208^{a}$ & $245^{\mathrm{b}}$ & $217^{\mathrm{ab}}$ & 10.1 & 0.025 \\
\hline \multicolumn{6}{|l|}{ Fermentation parameters } \\
\hline Total volatile fatty acids (VFA; mmol/g DM) & 3.35 & 3.57 & 3.56 & 0.09 & 0.067 \\
\hline \multicolumn{6}{|l|}{ Molar proportions of VFA (mol/100 mol) } \\
\hline Acetate (Ac) & 61.8 & 62.1 & 62.2 & 0.24 & 0.351 \\
\hline Propionate (Pr) & 21.4 & 21.7 & 21.6 & 0.24 & 0.642 \\
\hline Butyrate & 11.0 & 11.1 & 10.7 & 0.15 & 0.263 \\
\hline Minor VFA ${ }^{3}$ & $5.79^{b}$ & $5.16^{\mathrm{a}}$ & $5.46^{\mathrm{ab}}$ & 0.15 & 0.003 \\
\hline $\mathrm{Ac} / \operatorname{Pr}(\mathrm{mol} / \mathrm{mol})$ & 2.92 & 2.89 & 2.91 & 0.036 & 0.854 \\
\hline $\mathrm{NH} 3-\mathrm{N}(\mathrm{mg} / \mathrm{L})$ & $222^{b}$ & $207^{\mathrm{a}}$ & $222^{b}$ & 6.3 & 0.004 \\
\hline FOM $(g / k g \text { organic matter })^{4}$ & $311^{\mathrm{a}}$ & $333^{\mathrm{b}}$ & $338^{\mathrm{b}}$ & 8.6 & 0.025 \\
\hline
\end{tabular}

$\overline{a, b}$ Within each parameter, mean values with different superscripts differ $(\mathrm{P}<0.05)$. ${ }^{\mathrm{l}}$ Crude OC: samples were dried and pelletized; Exhausted OC: samples were dried and subjected to a second oil extraction using hexane; Cyclone OC: samples were obtained from cyclone decanters during drying COC. $n=$ number of samples. PGP: potential gas production; $c$ : fractional rate of gas production; Lag: time until the production of gas begins; AGPR: the average gas production rate until half of the PGP has been reached; FOM: fermented organic matter, DMED was calculated for a rumen passage rate of 0.042 per $\mathrm{h}^{3}$ Calculated as the sum of isobutyrate, isovalerate and valerate. ${ }^{4}$ Fermented organic matter calculated from VFA production as described by Demeyer(1991). 
The prediction equations to estimate the AGPR and FOM from OC type and chemical composition are shown in Table 14. The total sugars content was the best covariate to predict the AGPR, as the models including TSP content or any other chemical fractions as predictor variables had greater residual standard deviation (RSD) values (i.e., $0.68 \mathrm{~mL} / \mathrm{h}$ for TSP content; equations not shown). The sugars content had a positive linear effect $(\mathrm{P}<0.001)$ and a quadratic negative effect $(\mathrm{P}<0.001)$ on the AGPR. Moreover, an OC type effect was detected $(\mathrm{P}<0.001)$ on the intercept term, which had the lowest value in the CYOC model and the greatest in the EOC model.

The NDF content was the best predictor variable of FOM, as models including either sugars or TSP content had greater RSD values $(32.1$ and $35.0 \mathrm{~g} / \mathrm{kg} \mathrm{OM}$, respectively; equations not shown) than the model using NDF $(27.2 \mathrm{~g} / \mathrm{kg} \mathrm{OM})$. The NDF content had the same negative effect on FOM values for all OC types, as no OC type-NDF interaction was detected on the slope of the model. The type of OC affected $(\mathrm{P}=0.031)$ the intercept term, which had the lowest value in the CYOC model and the greatest in the EOC model.

The storage time was closely correlated $(\mathrm{P}<0.001)$ with sugars and TSP content (Table 13) and, therefore, prediction models of fermentation parameters including storage time were developed separately from those involving chemical analyses. As shown in Table 14, the prediction equations of the AGPR and FOM with OC type and storage time as a covariate had lower $\mathrm{R}^{2}$ and greater RSD values than those using OC type and chemical fractions. A linear and quadratic effect of storage time on the AGPR and FOM was observed, but the interaction between OC type and storage time $(\mathrm{P}<0.001)$ on the slope of the AGPR model indicates that the effect of storage time differed among OC types. For a fixed increment of time, the AGPR increased in the order CYOC $\leq \mathrm{COC}<\mathrm{EOC}$. In contrast, neither the intercept nor the slope of the model for FOM prediction was affected by OC processing type. 
Table 13. Correlation matrix (Pearson coefficient and $\mathrm{p}$ values in brackets; $n=42)$ of the chemical composition of olive cake (OC) samples and storage time with the average gas production rate (AGPR) and fermented organic matter (FOM) of OC samples measured in $24 \mathrm{~h}$ in vitro incubations (only $\mathrm{P}<0.05$ values are shown) ${ }^{1}$.

\begin{tabular}{|c|c|c|c|c|c|c|c|c|c|}
\hline Item & $\begin{array}{c}\text { Neutral } \\
\text { detergent fiber }\end{array}$ & $\begin{array}{c}\text { Acid } \\
\text { detergent } \\
\text { fiber }\end{array}$ & $\begin{array}{l}\text { Acid detergent } \\
\text { lignin }\end{array}$ & $\mathbf{N}$ & $\begin{array}{l}\text { Acid detergent } \\
\text { insoluble N }\end{array}$ & $\begin{array}{l}\text { Ether } \\
\text { extract }\end{array}$ & $\begin{array}{l}\text { Total } \\
\text { sugars }\end{array}$ & $\begin{array}{l}\text { Total soluble } \\
\text { polyphenols }\end{array}$ & $\begin{array}{c}\text { Storage } \\
\text { Time }\end{array}$ \\
\hline $\begin{array}{c}\text { Neutral detergent } \\
\text { fiber }\end{array}$ & - & $\begin{array}{c}0.99 \\
(<0.001)\end{array}$ & $\begin{array}{c}0.90 \\
(<0.001)\end{array}$ & - & $\begin{array}{c}0.43 \\
(0.004)\end{array}$ & $\begin{array}{c}-0.61 \\
(0.004)\end{array}$ & $\begin{array}{c}-0.43 \\
(0.004)\end{array}$ & $\begin{array}{c}-0.47 \\
(0.002)\end{array}$ & $\begin{array}{c}0.39 \\
(0.010)\end{array}$ \\
\hline $\begin{array}{l}\text { Acid detergent } \\
\text { fiber }\end{array}$ & - & - & $\begin{array}{c}0.93 \\
(<0.001)\end{array}$ & - & $\begin{array}{c}0.44 \\
(0.003)\end{array}$ & $\begin{array}{c}-0.63 \\
(<0.001)\end{array}$ & $\begin{array}{l}-0.40 \\
(0.009)\end{array}$ & $\begin{array}{l}-0.44 \\
(0.003)\end{array}$ & $\begin{array}{c}0.36 \\
(0.018)\end{array}$ \\
\hline $\begin{array}{l}\text { Acid detergent } \\
\text { lignin }\end{array}$ & - & - & - & - & $\begin{array}{c}0.49 \\
(0.001)\end{array}$ & $\begin{array}{c}-0.61 \\
(<0.001)\end{array}$ & $\begin{array}{l}-0.34 \\
(0.027\end{array}$ & $\begin{array}{l}-0.41 \\
(0.007)\end{array}$ & $\begin{array}{c}0.36 \\
(0.018)\end{array}$ \\
\hline $\mathrm{N}$ & - & - & - & - & $\begin{array}{c}0.58 \\
(<0.001)\end{array}$ & - & $\begin{array}{c}-0.33 \\
(0.035)\end{array}$ & - & - \\
\hline $\begin{array}{l}\text { Acid detergent } \\
\text { insoluble } \mathrm{N}\end{array}$ & - & - & - & - & - & $\begin{array}{c}-0.42 \\
(0.006)\end{array}$ & - & - & - \\
\hline Ether extract & - & - & - & - & - & - & - & - & - \\
\hline Total sugars & - & - & - & - & - & - & - & $\begin{array}{c}0.60 \\
(<0.001)\end{array}$ & $\begin{array}{c}-0.75 \\
(<0.001)\end{array}$ \\
\hline $\begin{array}{l}\text { Total soluble } \\
\text { polyphenols }\end{array}$ & - & - & - & - & - & - & - & & $\begin{array}{c}-0.74 \\
(<0.001)\end{array}$ \\
\hline \multicolumn{10}{|c|}{ Fermentable parameters } \\
\hline AGPR & $\begin{array}{l}-0.35 \\
(0.024)\end{array}$ & $\begin{array}{l}-0.31 \\
(0.048)\end{array}$ & - & $\begin{array}{c}-0.32 \\
(0.039)\end{array}$ & - & - & $\begin{array}{c}0.90 \\
(<0.001)\end{array}$ & $\begin{array}{c}0.69 \\
(<0.001)\end{array}$ & $\begin{array}{c}-0.76 \\
(<0.001)\end{array}$ \\
\hline FOM & $\begin{array}{c}-0.68 \\
(<0.001)\end{array}$ & $\begin{array}{c}-0.64 \\
(<0.001)\end{array}$ & $\begin{array}{c}-0.58 \\
(<0.001)\end{array}$ & - & - & - & $\begin{array}{c}0.82 \\
(<0.001)\end{array}$ & $\begin{array}{c}0.78 \\
(<0.001)\end{array}$ & $\begin{array}{c}-0.75 \\
(<0.001)\end{array}$ \\
\hline
\end{tabular}

${ }^{1}$ AGPR: the average gas production rate until it reached half of PGP; fermented organic matter (FOM) was calculated from volatile fatty acids production as described by Demeyer (1991). 
Table 14. Models for predicting the average gas production rate (AGPR; $\mathrm{mL} / \mathrm{h}$ ) and fermented organic matter (FOM; $\mathrm{g} / \mathrm{kg} \mathrm{OM})$ after $24 \mathrm{~h}$ in vitro incubation of olive cake (OC) samples using OC type (crude (COC), exhausted (EOC) and cyclone (CYOC)) as the fixed effect and either chemical fractions or storage time as covariates $(n=42)^{1}$.

\begin{tabular}{|c|c|c|c|c|c|c|c|c|}
\hline \multirow{2}{*}{ Covariate } & \multirow{2}{*}{ Parameter $^{3}$} & \multirow{2}{*}{ Prediction Equation ${ }^{4}$} & \multicolumn{6}{|c|}{ P-Value $^{6}$} \\
\hline & & & RSD $^{\circ}$ & $p_{\text {OC }}$ & $p_{\mathrm{L}}$ & $p_{\mathrm{OC}} * \mathrm{~L}$ & $p_{Q}$ & $\boldsymbol{R}^{2}$ \\
\hline $\begin{array}{l}\text { Chemical } \\
\text { fractions }(\mathrm{g} / \mathrm{kg} \\
\text { dry matter })\end{array}$ & $\operatorname{AGPR}(\mathrm{mL} / \mathrm{h})$ & $\begin{array}{c}(1.54( \pm 0.169)+\mathbf{A})+0.039( \pm 0.0040) \text { Total sugars - } \\
0.00010( \pm 0.000021) \text { Total sugars }{ }^{2} \\
\text { A values: }-0.393( \pm 0.1601), 0 \text { and }-0.645( \pm 0.1982) \text { for } \\
\text { COC, EOC and CYOC, respectively }\end{array}$ & 0.41 & $<0.001$ & $<0.001$ & - & $<0.001$ & 0.898 \\
\hline $\begin{array}{l}\text { Chemical } \\
\text { fractions }(\mathrm{g} / \mathrm{kg} \\
\text { dry matter })\end{array}$ & $\begin{array}{c}\text { FOM } \\
(\mathrm{g} / \mathrm{kg} \text { organic matter })\end{array}$ & $\begin{array}{c}(743( \pm 39.1)+\mathbf{A})-0.64( \pm 0.059) \text { Neutral detergent } \\
\text { fiber } \\
\text { A values: }-69.1( \pm 11.84), 0 \text { and }-124( \pm 18.2) \text { for COC, } \\
\text { EOC and CYOC, respectively }\end{array}$ & 27.2 & 0.031 & $<0.001$ & - & - & 0.767 \\
\hline $\begin{array}{l}\text { Storage time } \\
\text { (months) }\end{array}$ & AGPR (mL/h) & $\begin{array}{c}(6.55( \pm 0.480)+\mathbf{A})+\mathbf{B} * \text { Time }+0.0355( \pm 0.00907) \\
\text { Time }^{2} \\
\text { A values: }-1.65( \pm 0.553), 0 \text { and }-2.56( \pm 0.663) \text { for COC, } \\
\text { EOC and CYOC, respectively } \\
\text { B values: }-0.71( \pm 0.122),-0.95( \pm 0.120) \text { and }-0.58 \\
( \pm 0.109) \text { for COC, EOC and CYOC, respectively }\end{array}$ & 0.55 & 0.002 & - & $<0.001$ & $<0.001$ & 0.795 \\
\hline $\begin{array}{l}\text { Storage time } \\
\text { (months) }\end{array}$ & $\begin{array}{c}\text { FOM } \\
(\mathrm{g} / \mathrm{kg} \text { organic matter })\end{array}$ & $432( \pm 17.4)-27.2( \pm 5.91) *$ Time $+1.07( \pm 0.481)$ & 35.7 & $<0.001$ & - & - & 0.019 & 0.618 \\
\hline
\end{tabular}

${ }^{1}$ COC samples were dried and pelletized; EOC samples were dried and subjected to an extraction using hexane; CYOC samples were obtained from a cyclone separator after drying the crude samples. ${ }^{3}$ AGPR: the average gas production rate until it reached half of PGP; FOM: fermented organic matter calculated from volatile fatty acids production as described by Demeyer (1991). ${ }^{4}$ Values in parentheses are standard errors. ${ }^{5}$ Residual standard deviation. ${ }^{6} p_{\mathrm{OC}}$ : effect of OC type; $p_{\mathrm{L}}$ : linear effect of covariate; $p_{\mathrm{Q}}$ : quadratic effect of covariate; $p_{\mathrm{OC}}{ }^{*}$ : OC type-covariate interaction effect

$$
\sim 89 \sim
$$




\section{IV.4. Discussion}

IV.4.1. Influence of olive cake processing on chemical composition and in vitro fermentation

The chemical composition of COC and EOC samples was in agreement with values reported by others (Heuzé et al., 2015; Molina-Alcaide and Yáñez-Ruiz, 2008; Alburquerque et al., 2004), and both OC types showed high variability. Factors such as the olive cultivar, ripeness of the fruit, agronomic conditions, storage time in open-air ponds and climatic conditions influence the chemical composition of the alperujo (Dermeche et al., 2013) and, therefore, the composition of the OC obtained. As expected, EE content was lower in EOC than in $\mathrm{COC}$ due to the second oil extraction and this caused an increase in the remaining chemical components, although only NDF showed significant differences. The degree of lignification of NDF and ADF fractions $(36 \%$ and $50 \%$, respectively; calculated as $($ lignin/NDF $) \times 100)$ was similar between OC types reflecting no changes due to processing. All OC samples had low $\mathrm{N}$ content $(\leq 23.5 \mathrm{~g} / \mathrm{kg} \mathrm{DM})$, and in accordance with others (Heuzé et al., 2015; Molina-Alcaide and Yáñez-Ruiz, 2008) ADIN was a high proportion of total N (51.3, 54.8 and 44.7\% for COC, EOC and CYOC, respectively), indicating low $\mathrm{N}$ availability. However, $\mathrm{NH}_{3}-\mathrm{N}$ concentrations in the in vitro incubations were above the level limiting in vitro ruminal microbial growth (Satter and Slyter, 1974) for all OC samples due to the use of an N-enriched medium. The greater ADIN concentrations in EOC compared with COC and CYOC samples were attributed to the second heat treatment applied to remove the hexane solvent used in the extraction of pomace olive oil from COC, as heating may lead to the formation of indigestible compounds via Maillard reactions between sugar aldehyde groups and free amino groups (Broderick et al., 2000).

To the best of our knowledge, there was no previous information on the chemical composition of CYOC in the literature. The lower NDF and ADF content of CYOC than in COC and EOC may reflect the smaller amount of olive stone fragments, as CYOC is composed of the lighter pomace particles floating in the air collected during drying the alperujo. The lower NDF, ADF and ADL content of CYOC compared with both COC and EOC also supports this hypothesis, as hemicellulose, cellulose and lignin are the main components of olive stones (Rodríguez et al., 2008). In 
addition, CYOC had the greatest EE content and, therefore, it is expected to have greater energy content for ruminants than $\mathrm{COC}$ and EOC.

In agreement with the results reported by others (reviewed by Molina-Alcaide and Yáñez-Ruiz, (2008)) the ruminal degradability of OC was low, but there was a wide variability in DMED values which ranged from 99.2 to $378 \mathrm{~g} / \mathrm{kg}$ DM. For example, Álvarez-Rodríguez et al. (2009) observed that only $120 \mathrm{~g} / \mathrm{kg}$ DM of a sample of EOC disappeared from the rumen after $72 \mathrm{~h}$ of incubation, whereas this value was $370 \mathrm{~g} / \mathrm{kg}$ DM for a COC sample, and a slightly greater in situ value (420 g/ $\mathrm{kg} \mathrm{DM})$ was reported by Martín-García et al. (2003) for a COC sample. Variations in DMED could be partly explained by the chemical composition of OC, as DMED was positively correlated with total sugars $(\mathrm{P}<0.001)$ and negatively with $\mathrm{NDF}, \mathrm{ADF}$ and ADL $(\mathrm{P} \leq 0.024$; values not shown) content.

Both the unchanged VFA production and VFA profile in all OC groups indicate a similar fermentation pattern. Unsaturated free fatty acids resulting from the triglyceride hydrolysis are toxic to fibrolytic bacteria (Maia et al., 2007), but the similar acetate and butyrate proportions observed in the three OC groups does not indicate a negative effect of the high EE content of some COC and CYOC samples on fiber fermentation. A maximal level of $60 \mathrm{~g}$ of fat per $\mathrm{kg}$ of $\mathrm{DM}$ is usually recommended in the diet of ruminants to avoid reductions in fiber digestibility (NRC, 2001); other studies revealed no negative effect of greater EE levels both in vivo (Toral et al., 2010) and in vitro (Gómez-Cortés et al., 2008). Finally, the lack of correlation between EE and any fermentation parameter supports the idea that there was no negative effect of the high EE content on ruminal fermentation.

The hydrolysis of olive oil lipids has been reported to be much lower than that of more unsaturated oils such as linseed oil $(68 \%$ vs. $95 \%$ at $24-\mathrm{h}$ incubation, respectively) (Garton et al., 1961), thus liberating less fatty acids. In addition, the high lignification degree of the NDF in all OC types $(\geq 34.9 \%)$ indicates low NDF degradability and this may help to explain the lack of an apparent negative effect of EE content on total VFA production from COC and CYOC samples. In contrast, the lower the AGPR observed for COC and CYOC compared with EOC might indicate a reduced fermentation. However, gas production data from samples with high EE 
content should be interpreted with caution, as no gas arises from EE fermentation in the rumen, and total gas production can even be reduced by fat supplementation due to decreased $\mathrm{CH}_{4}$ production (Danielsson et al., 2017).

\section{IV.4.1. Estimation of fermentation parameters}

The average gas production rate was influenced by the OC processing type and the intercept of the model was greater for EOC than for COC and CYOC, possibly due to the differences in their EE content, and, therefore, in the amount of potentially fermentable dry matter, as no gas is formed from fat fermentation. The positive linear effect of sugars content in the prediction equations of the AGPR reflects that sugars contribute to increased gas production in the first hours of incubation, when sugars are rapidly and extensively fermented by rumen microorganisms. In fact, sugars/EE ratio was greater in EOC than in COC and CYOC samples (6.8, 0.31 and 0.28, respectively). However, there was also a negative quadratic effect of sugars content that might be due to the positive relationship observed between sugars and TSP content in OC samples. The presence of TSP in feeds can reduce feed ruminal degradability (Theodorou et al., 2006), and negative correlations between TSP content and DM degradability are frequently reported (Molina-Alcaide et al., 2017).

The significant effect of OC type on the intercept of the FOM model indicates differences between OC types, with COC and CYOC having lower FOM values than EOC for samples with similar NDF content. This might be related to the greater EE content in COC and CYOC, as EE was not related to NDF content and EE does not lead to VFA production (only low VFA amounts are generated from glycerol fermentation (Van Soest, 1994)). The lack of influence of OC type on the slope of the FOM prediction model reflects similar changes in FOM with increases in NDF for all OC types, as clearly shown by the similar slopes observed in the linear models developed individually for each OC group $(\mathrm{r}=-0.622,-0.648$ and -0.690 for COC, EOC and CYOC samples, respectively). This is consistent with the similar lignification degree of the NDF in all OC types $(36.0 \%, 34.9 \%$ and $37.0 \%$ for COC, EOC and CYOC, respectively), as lignin is one of the major factors limiting NDF degradability.

Models involving OC type and storage time as predictor variables were also developed, as this would be a cheap and rapid form to estimate fermentation parameters. 
Differences in intercept values on the AGPR model were related to the differences in EE content among OC types that were not correlated with changes in the covariate of the model. The negative effect of storage time on the slope is in accordance with the observed changes in the chemical composition of OC over the storage period. Sugars content in OC samples clearly decreased as storage time in the pond augmented $(\mathrm{r}=$ $-0.769 ; \mathrm{P}<0.001 ; n=42$ ), whereas NDF content, a less fermentable fraction, increased with advancing storage time $(\mathrm{r}=0.395 ; \mathrm{P}=0.010 ; n=42)$.

The significant interaction between OC type and storage time on the slope observed in the AGPR model reflects a different timely evolution for each OC type. The greater slope of the EOC model compared with those for COC and CYOC samples may reflect the greater increases in NDF fraction with time $(167 \mathrm{~g} / \mathrm{kg} \mathrm{DM}$ from months 1 to 8) in EOC compared with those in COC and CYOC (109 and $87 \mathrm{~g} / \mathrm{kg}$ DM, respectively), because NDF fermentability is lower than in other fractions (i.e., sugars, starch, etc.). In contrast, in the prediction of FOM, there was no effect of OC type on the intercept, which is consistent with the lack of correlation between EE and storage time. The negative effect of storage time on the slope of the FOM model reflected the decrease in total sugars and, therefore, in OM fermentation as the alperujo storage time advanced. Finally, the quadratic effect of storage time in all models confirms the results of Marcos et al. (2019), who observed that the loss of the nutritive value of $\mathrm{OC}$ was more pronounced during the first months of storage and almost imperceptible from 6 storage months.

Although the models using OC type and storage time as predictor variables had lower $\mathrm{R}^{2}$ and greater $\mathrm{RSD}$ values than those involving OC type and the chemical composition, it has to be taken into account that analysis of the chemical composition is expensive and time consuming. The possibility of predicting in vitro fermentation parameters from OC type and storage time could be a cheap and rapid alternative.

\section{IV.5. Conclusions}

The results show that the chemical composition of OC by-products is highly variable, markedly affected by the processing type and storage time of the alperujo before processing. However, all samples had high lignification of both NDF and ADF fractions and low $\mathrm{N}$ content, with ADIN being greater than $44 \%$ of total $\mathrm{N}$. Cyclone 
OC had the lowest NDF and the greatest EE content, as well as an intermediate sugars content, which indicates that it would have greater nutritive value for ruminants than COC and EOC. All OC types were poorly degraded in vitro and, therefore, their nutritive value for ruminants is highly dependent on their EE content. Models using OC processing type, and either the chemical composition or the alperujo storage time before processing as covariates, were useful to predict the in vitro ruminal fermentation variables of OC.

Author Contributions: P.G.-R. and C.d.B. obtained all OC samples; C.N.M. and M.D.C. designed and performed the in vitro trials; C.N.M. and C.d.B. were responsible for the statistical analysis; C.N.M. and M.D.C. wrote the draft; P.G.-R. and C.d.B. provided advice and critically reviewed the manuscript; All authors revised and approved the final manuscript.

Funding: This research was funded by the Spanish Ministry of Economy and Competitiveness (AGL2016-75322-C2-1-R and AGL2014-56653-C3-1-R projects).

Acknowledgments: Authors are grateful to Clara González Alonso (SACYR Industrial S.L.U.) and Fernando Bacha (NACOOP S.A.) for providing the samples used in this study.

Conflicts of Interest: The authors declare no conflict of interest.

References

Alburquerque, J. A., Gonzálvez, J., García, D., and Cegarra, J. (2004). Agrochemical characterization of "alperujo", a solid by-products of the two-phase centrifugation method for olive oil extraction. Bioresource Technology 91, 195-200.

Álvarez-Rodríguez, J., Muñoz, F., and Margalida, J. (2009). Nutritive value of crude and extracted two-stage olive cakes produced in Aragón (Spain). Revista Electrónica de Veterinaria 10, 1-8.

Association of Official Analytical Chemists (AOAC). (2005). Official Methods of Analysis, 18th ed. AOAC International.

Broderick, G. A., Wallace, R. J., and Ørskov, E. R. Control of rate and extent of protein degradation. California, USA, ed. Tsuda, T., Susaki, Y., Kawashima, R. 2000. In 
"Physiological Aspects of Digestion and Metabolism in Ruminants". pp. 541-592. Academic Press.

Danielsson, R., Ramin, M., Bertilsson, J., Lund, P., and Huhtanen, P. (2017). Evaluation of a gas in vitro system for predicting methane production in vivo. Journal of Dairy Science 100, 8881-8894.

Demeyer, D. Quantitative aspects of microbial metabolism in the rumen and hindgut. Paris, France, ed. Jouany, J. P. 1991. In "Rumen Microbial Metabolism and Ruminant Digestion". pp. 217-237. INRA Editions.

Dermeche, S., Nadour, M., Larroche, C., Moulti-Mati, F., and Michaud, P. (2013). Olive mill wastes: Biochemical characterizations and valorization strategies. Process Biochemistry 48, 1532-1552.

FAO. (2018). Food and Agriculture Organization of the United Nations Home Page. [consulted 20/11/2018]. Available in: http://www.fao.org/docrep/015/am081m/am081m00.html

García-Martínez, R., Ranilla, M. J., Tejido, M. L., and Carro, M. D. (2005). Effects of disodium fumarate on in vitro rumen microbial growth, methane production and fermentation of diets differing in their forage concentrate ratio. British Journal of Nutrition 94, 71-77.

Garton, G. A., Lough, A. K., and Vioque, E. (1961). Glyceride hydrolysis and glycerol fermentation by sheep rumen contents. Journal of General Microbiology 25, 215 225.

Goering, M. K., and Van Soest, P. J. (1970). Forage Fiber Analysis (Apparatus, Reagents, Procedures and Some Applications). In "Agricultural Handbook; Agriculture Handbook No. 379". Agricultural Research Services.

Gómez-Cortés, P., Frutos, P., Mantecón, A. R., Juárez, M., de la Fuente, M. A., and Hervás, G. (2008). Milk production, conjugated linoleic acid content, and in vitro ruminal fermentation in response to high levels of soybean oil in dairy ewe diet. Journal of Dairy Science 91, 1560-1569.

Heuzé, V., Tran, G., Gomez-Cabrera, A., and Lebas, F. (2015). Olive oil cake and byProducts. In "Feedipedia, a Programme by INRA, CIRAD, AFZ and FAO". [consulted 11/02/2019]. Available in: https://www.feedipedia.org/node/32 
Maia, M. R., Chaudhary, L. C., Figueres, L., and Wallace, R. J. (2007). Metabolism of polyunsaturated fatty acids and their toxicity to the microflora of the rumen. Antonie Van Leeuwenhoek 91, 303-314.

Marcos, C. N., De Evan, T., Garcia-Rebollar, P., de Blas, C., and Carro, M.D. (2019). Influence of storage time and processing on chemical composition and in vitro ruminal fermentation of olive cake. Journal of Animal Physiology and Animal Nutrition (Under review).

Martín-García, A. I., Moumen, A., Yáñez-Ruiz, D. R., and Molina-Alcaide, E. (2003). Chemical composition and nutrients availability for goats and sheep of two-stages olive cake and olive leaves. Animal Feed Science and Technology 107, 61-74.

Molina-Alcaide, E., Carro, M. D., Rodela, M., Weisbjerg, M. R., Lind, V., and NovoaGarrido, M. (2017). In vitro ruminal fermentation and methane production of different seaweed species. Animal Feed Science and Technology 228, 1-12.

Molina-Alcaide, E., and Yáñez-Ruiz, D. R. (2008). Potential use of olive by-products in ruminant feeding: a review. Animal Feed Science and Technology 147, 247-264.

NRC (National Research Council). (2001). Nutrient Requirements of Dairy Cattle, 7th ed. National Academy of Sciences.

Robertson, J. B., and Van Soest, P. J. The detergent system of analysis and its application to human foods. New York, USA, ed. James, W. P. T., Theander, O. 1981. In "The Analysis of Dietary Fiber in Food". pp. 123-142. Marcel Dekker.

Rodríguez, G., Lama, A., Rodríguez, R., Jiménez, A., Guillén, R., and FernándezBolaños, J. (2008). Olive stone an attractive source of bioactive and valuable compounds. Bioresource Technology 99, 5261-5269.

Romero-Huelva, M., Ramírez-Fenosa, M. A., Planelles-González, R., García-Casado, P., and Molina-Alcaide, E. (2017). Can by-products replace conventional ingredients in concentrate of dairy goat diet?. Journal of Dairy Science 100, 4500-4512.

SAS Institute. (2017). SAS/STAT®Users Guide, Version 9.3. SAS Inst. Inc.

Satter, L. D., and Slyter, L. L. (1974). Effect of ammonia concentration on rumen microbial protein production in vitro. British Journal of Nutrition 32, 199-208.

Singleton, V. L., and Rossi, J. A. (1965). Colorimetry of total phenolics with phosphomolybdic-phosphotungstic acids reagents. American Journal of Enology and 


\section{Viticulture 16, 144-158.}

Theodorou, M. K., Kingston-Smith, A. H., Winter, A. L., Lee, M. R. F., Minchin, F. R., Morris, P., and MacRae, J. (2006). Polyphenols and their influence on gut function and health in ruminants. Environmental Chemistry Letters 4, 121-126.

Toral, P. G., Shingfield, K. J., Hervás, G., Toivonen, V., and Frutos, P. (2010). Effect of fish oil and sunflower oil on rumen fermentation characteristics and fatty acid composition of digesta in ewes fed a high concentrate diet. Journal of Dairy Science 93, 4804-4817.

Van Soest, P. J. (1994). Nutritional Ecology of the Ruminant, 2nd ed. pp. 476. Cornell University Press.

Van Soest, P. J., Robertson, J. B., and Lewis, B. A. (1991). Methods for dietary fiber, neutral detergent fiber and nonstarch polysaccharides in relation to animal nutrition. Journal of Dairy Science 74, 3583-3597.

Weatherburn, M. W. (1967). Phenol-hypochlorite reaction for determination of ammonia. Analytical Chemistry 39, 971-974.

Yemm, E. W., and Willis, A. J. (1954). The estimation of carbohydrates in plant extracts by anthrone. Biochemical 157, 508-514. 
98 


\section{Chapter V. NUTRITIVE VALUE}

OF TOMATO POMACE FOR RUMINANTS AND ITS

\section{INFLUENCE ON IN VITRO}

\section{METHANE PRODUCTION}

Marcos, C. N., De Evan, T., Molina-Alcaide, E., and Carro, M. D. (2019). Nutritive Value of Tomato Pomace for Ruminants and Its Influence on In Vitro Methane Production. Animals 9, 343-358. doi: 10.3390/ani9060343

ISI Journal Citation Reports Ranking 2018: Animals was ranked 11 out of 61 Journals in the area of "Agriculture, Dairy \& Animal Science" 
$\sim 100 \sim$ 
Simple Summary: Reutilization of agroindustrial by-products in animal feeding could contribute to the reduction of environmental problems associated with their accumulation, but it is necessary to assess their nutritive value. Tomato pomace (TP) is a by-product of the tomato industry that could be used in ruminant feeding, but data on its nutritive value are limited. The aim of this work was to analyze the chemical composition, in vitro rumen fermentation, and intestinal digestibility of 12 TP samples obtained from two processing plants at different times during the tomato campaign and to assess the in vitro fermentation of diets including increased TP amounts. The chemical composition of TP showed little variability. Samples of TP had high fiber, protein, and fat content and were rapidly fermented in the rumen, but the in vitro intestinal digestibility of the protein was low. The in vitro results provide useful information for including TP in ruminant diets, indicating that amounts of TP up to 180 $\mathrm{g} / \mathrm{kg}$ could be included in a diet for fattening ruminants without negatively affecting rumen fermentation, but these results should be confirmed in vivo.

Abstract: The objective of this study was to determine the variability in nutritive value for ruminants of tomato pomace (TP) samples and analyze its effect on in vitro fermentation when it was included in a high-concentrate diet. Twelve TP samples were obtained from two processing plants at weekly intervals and analyzed for chemical composition, in vitro rumen fermentation, and intestinal digestibility. The chemical composition of TP did not differ between processing plants and only slight variations were observed among sampling times. Tomato pomace had a low dry matter content $(<300 \mathrm{~g} / \mathrm{kg})$, a high content of neutral detergent fiber, crude protein, and ether extract (572, 160, and $82.7 \mathrm{~g} / \mathrm{kg}$ dry matter on average, respectively), and was rapidly fermented in the rumen. Protein degradability at $16 \mathrm{~h}$ in situ incubation was $510 \mathrm{~g} / \mathrm{kg}$ and in vitro intestinal digestibility of protein was low (430-475 g/kg). Replacing soybean meal and barley straw by dried TP increased the in vitro fermentation rate and the production of volatile fatty acids and reduced $\mathrm{NH}_{3}-\mathrm{N}$ concentrations without affecting $\mathrm{CH}_{4}$. In summary, TP samples showed little variability in nutritive value over sampling time and TP of up to $180 \mathrm{~g} / \mathrm{kg}$ could be included in high-concentrate diets without negatively affecting rumen fermentation.

Keywords: tomato pomace; in vitro rumen fermentation; methane; rumen degradability; intestinal digestibility 


\section{V.1. Introduction}

The world production of processing tomato has increased up to $37.8 \times 10^{6}$ tons in 2017 according to estimates of the World Processing Tomato Council (WPTC, 2019). In the European Union, Italy and Spain are the greatest tomato producers, accounting for $4.7 \times 10^{6}$ and $2.8 \times 10^{6}$ tons of tomatoes for processing in 2017 , respectively. Tomato pomace (TP) is a by-product of the tomato industry that consists mainly of peels, seeds, and small quantities of pulp that remain after the production of juice, paste, sauce, and other processed products, representing between $5 \%$ and $10 \%$ of the original fruits (Fondevila et al., 1994). The high water content of TP (usually greater than $75 \%$ ) due to the water added in the last step of the industrial process is the most important limitation for its further utilization in animal feeding, as fresh TP spoils very quickly (Caluya, 2000); therefore, the use of fresh TP for animal feeding is generally restricted to farms closely located to the processing plants (Denek and Can, 2006), also limited because high-moisture feeds reduce feed intake in ruminants. Tomato pomace can be preserved either by drying or by ensiling with cereal straw (Denek and Can, 2006), but these procedures increase their price. The use of TP in animal feeding would contribute to the reduction of environmental problems caused by their accumulation, mainly related to bad odor and pests breeding in accumulations of spoiled TP (Caluya et al., 2003). In addition, TP can improve the quality of animal products by increasing the content of fatty acids beneficial to human health (Arcos-Pérez et al., 2017; Vasta et al., 2008). However, the nutritive value of TP depends on many factors, such as cultivars, season, or processing, among others (Del Valle et al., 2006), but current knowledge on its variability is limited.

Previous studies have shown that the inclusion of tomato fruit wastes in the diet of goats reduced $\mathrm{CH}_{4}$ emissions (Romero-Huelva and Molina-Alcaide, 2013; RomeroHuelva et al., 2012) and this antimethanogenic effect has also been observed in vitro (Romero-Huelva et al., 2013). The antimethanogenic mechanisms of tomato fruit wastes are still unknown (Romero-Huelva and Molina-Alcaide, 2013), but the presence of bioactive substances affecting the rumen methanogenic archaea cannot be ignored. However, to our best knowledge, the possible influence of TP on rumen $\mathrm{CH}_{4}$ production has not yet been tested. Therefore, the first objective of this study was to analyze the variability in the nutritive value of $\mathrm{TP}$ samples collected from tow processing plants 
during the tomato campaign. The second objective was to assess the effects of including increasing doses of TP in a diet for fattening lambs on in vitro fermentation and $\mathrm{CH}_{4}$ production.

\section{V.2. Materials and methods}

\section{V.2.1. Tomato pomace samples}

Twelve samples of TP were obtained from two of the biggest Spanish tomato processing plants (Tomates del Guadiana Soc. Coop., Badajoz, Spain, and PRONAT, Badajoz, Spain) during the 2016 tomato harvesting campaign. The tomato campaign in Spain is usually concentrated in August and September. Samples (4-5 kg) were obtained weekly at each plant on the 12th, 19th, and 26th August and the 2nd, 9th, and 16th of September, frozen $\left(-20^{\circ} \mathrm{C}\right)$ and lyophilized. In all cases, samples were the final tomato-processing disposal. All samples were ground at $2 \mathrm{~mm}$, and subsamples were ground at $1 \mathrm{~mm}$ before chemical analyses and in vitro incubations.

\section{V.2.2. Animals and feeding}

Four adult rumen-fistulated Lacaune sheep $(63.5 \pm 2.05 \mathrm{~kg}$ body weight $(\mathrm{BW}))$ were individually housed and had free access to fresh water over the trial. Animals were fed twice daily (8:00 and 18:00) a 2:1 grass hay:concentrate diet at a rate of $45 \mathrm{~g}$ dry matter $(\mathrm{DM}) / \mathrm{kg} \mathrm{BW}^{0.75}$. The diet contained 114,365 , and $160 \mathrm{~g}$ of crude protein (CP), neutral detergent fiber (NDF), and acid detergent fiber (ADF) per kg DM, respectively, and was formulated to meet maintenance requirements of the experimental animals (NRC, 2007). Sheep were managed in accordance with the Spanish guidelines for experimental animal protection (Royal Decree 53/2013 of 1st February on the protection of animals used for experimentation or other scientific purposes) and all experimental procedures were approved by the Institutional Animal Care and Use Committee of the Comunidad Autónoma de Madrid (PROEX 035/17).

\section{V.2.3. Experimental design}

The study comprises two experiments. The in vitro rumen fermentation and the intestinal digestibility of protein (IDCP) of the TP samples were measured in Experiment 1, whereas Experiment 2 was designed to analyze the effects of including 
dried TP in the diet on in vitro rumen fermentation, with special emphasis on $\mathrm{CH} 4$ production.

\section{V.2.3.1. Experiment 1: in vitro fermentation of TP samples}

Two in vitro trials were conducted on different days using the same methodology and in each of them there were four replicates per TP sample by using the ruminal fluid from each sheep as inoculum.

The first trial was carried out to determine the gas production kinetics of samples and the second one to assess the main fermentation parameters and $\mathrm{CH}_{4}$ production. Ruminal contents of each sheep were obtained before the morning feeding, strained through four layers of cheesecloth into previously warmed thermal flasks, and immediately transported to the laboratory. The fluid of each sheep was independently mixed with pre-warmed $\left(39{ }^{\circ} \mathrm{C}\right)$ culture medium (Goering and Van Soest (1970); without trypticase) in a proportion 1:4 under $\mathrm{CO}_{2}$ flushing. The medium of Goering and Van Soest (1970) was modified by replacing the $\left(\mathrm{NH}_{4}\right) \mathrm{HCO}_{3}$ with $\mathrm{NaHCO}_{3}$ and excluding the trypticase to avoid N supply. Samples (200 mg of DM) of each feed were accurately weighed into $60-\mathrm{mL}$ vials. Vials were filled up with $20 \mathrm{~mL}$ of the rumen fluid-culture medium mixture using a Watson-Marlow 520UIP31 peristaltic pump (Watson-Marlow Fluid Technology Group, Cornwall, UK), sealed with rubber stoppers, and incubated at $39^{\circ} \mathrm{C}$ for $120 \mathrm{~h}$. Gas production was measured at 3, 6, 9, 12 , $15,22,26,31,36,48,58,72,96$, and $120 \mathrm{~h}$ using a pressure transducer (Delta Ohm DTP704-2BGI, Herter Instruments SL, Barcelona, Spain) and a plastic syringe and the gas produced at each sampling time was released to prevent gas accumulation. Two blanks (vials without sample) per inoculum were also incubated in this trial to correct gas production values for endogenous production. The potential in vitro DM degradability (PDMD) was determined by weighing $300 \mathrm{mg}$ of each feed (3 bags per feed) into polyester bags of $30 \mu \mathrm{m}$ pore size (Ankom Corp \#57, Ankom Technology Corp., Fairport, NY, USA) and incubating the bags in a 1:4 mixture of ruminal fluid and the incubation medium of Goering and Van Soest (1970) in an Ankom Daisy II incubator at $39^{\circ} \mathrm{C}$ under continuous rotation for $120 \mathrm{~h}$. A mixture of equal parts of the ruminal fluid from each sheep was used as inoculum. After $120 \mathrm{~h}$, bags were washed with cold water, dried at $60{ }^{\circ} \mathrm{C}$ for $48 \mathrm{~h}$, and weighed to calculate PDMD. 
In the second in vitro trial, vials were incubated at $39^{\circ} \mathrm{C}$ for $24 \mathrm{~h}$ as described before and samples to analyze the main fermentation parameters were taken. Gas production was measured and a gas sample $(10 \mathrm{~mL})$ was stored in an evacuated tube (Terumo Europe N.V., Leuven, Belgium) for analysis of $\mathrm{CH}_{4}$ concentration. Vials were then uncapped, their content was homogenized, the $\mathrm{pH}$ was immediately measured (Crison Basic $20 \mathrm{pH}$-meter, Crisson Instruments, Barcelona, Spain), and $3 \mathrm{~mL}$ of the vials'contents were mixed with $3 \mathrm{~mL}$ of $0.5 \mathrm{M} \mathrm{HCl}$. Samples were frozen $\left(-20{ }^{\circ} \mathrm{C}\right)$ until volatile fatty acid (VFA) and $\mathrm{NH}_{3}-\mathrm{N}$ analyses.

\section{V.2.3.2. Experiment 1: in vitro intestinal digestibility of tomato pomace samples}

The determination of the IDCP of TP samples followed the three-step procedure described by Gargallo et al. (2006) and was performed as detailed by Belverdy et al. (2019). Briefly, $3 \mathrm{~g}$ of each TP sample ( $2 \mathrm{~mm}$ size) was weighed into nylon bags $(7 \times$ $14 \mathrm{~cm} ; 46 \mu \mathrm{m}$ pore size) and incubated in the rumen of each sheep immediately before the afternoon feeding on 2 different days. After $16 \mathrm{~h}$ of in situ incubation, bags were washed, frozen $\left(-20{ }^{\circ} \mathrm{C}, 48 \mathrm{~h}\right)$ to facilitate the detachment of particle-associated bacteria, thawed, washed 3 times with cold water ( $5 \mathrm{~min}$ each) in a turbine washing machine, frozen again $\left(-20^{\circ} \mathrm{C}\right)$, lyophilized, and weighed. Finally, bag residues were analyzed for $\mathrm{N}$ content to calculate the in situ degradability of $\mathrm{CP}$. Bag residues were pooled by TP sample and sheep and $0.5 \mathrm{~g}$ of each were weighed in duplicate into nylon bags $(5 \times 5 \mathrm{~cm} ; 46 \mu \mathrm{m}$ pore size). Bags were incubated into Daisy II incubation bottles (ANKOM Tech. Co., Fairport, NY, USA) containing 2 liters of a $0.1 \mathrm{~N} \mathrm{HCl}$ solution $\left(\mathrm{pH} 1.9 ; 39^{\circ} \mathrm{C}\right)$ with $1 \mathrm{~g}$ per 1 of pepsin (P-7000, Sigma, St. Louis, MO, USA) under constant rotation at $39^{\circ} \mathrm{C}$ for $1 \mathrm{~h}$. Bags were then rinsed with tap water and incubated in a pancreatin solution $(0.5 \mathrm{M} \mathrm{KH} 2 \mathrm{PO} 4$ buffer, $\mathrm{pH} 7.75,50 \mathrm{ppm}$ of thymol and $3 \mathrm{~g}$ per 1 of pancreatin; P-7545, Sigma, St. Louis, MO, USA) at $39^{\circ} \mathrm{C}$ for $24 \mathrm{~h}$ under constant rotation. Finally, bags were rinsed with tap water, dried at $40^{\circ} \mathrm{C}$ for $72 \mathrm{~h}$, and weighed. Residues of the in vitro incubation were pooled by sheep and TP sample and analyzed for $\mathrm{N}$ concentration to calculate IDCP values.

\section{V.2.3.3. Experiment 2: in vitro fermentation of diets containing tomato pomace}

The objective of this experiment was to analyze the effects of including increasing amounts of dried TP in a high-concentrate diet for fattening lambs (control 
diet) on in vitro rumen fermentation. Three additional diets were formulated by replacing different amounts of barley straw, soybean meal, and wheat bran in the control diet with 60,120 , or $180 \mathrm{~g}$ per $\mathrm{kg}$ (fresh matter basis) of a dried TP sample. A composited sample of the TP samples tested in Experiment 1 was used and it contained 967, 163, 572, 446, and $95.2 \mathrm{~g}$ of organic matter (OM), CP, NDF, ADF and ether extract (EE) per kg DM, respectively. All diets were formulated to have similar CP and NDF content to the control diet and therefore TP replaced fibrous (barley straw and wheat bran) and protein (soybean meal) conventional ingredients. The ingredients and chemical compositions of the four experimental diets are given in Table 15.

Table 15. Ingredients and chemical composition of control and experimental diets containing increased amounts of tomato pomace (TP) used in Experiment 2.

\begin{tabular}{ccccc}
\hline Item & Control & TP6 & TP12 & TP18 \\
\hline $\begin{array}{c}\text { Ingredient }(\mathrm{g} / \mathrm{kg} \text { fresh } \\
\text { matter) }\end{array}$ & & & & \\
Barley & 315 & 315 & 315 & 315 \\
Corn & 252 & 275 & 284 & 285 \\
Wheat & 130 & 130 & 130 & 130 \\
Barley Straw & 120 & 85 & 35 & 20 \\
Soybean meal 46\% & 110 & 96 & 66 & 60 \\
Wheat bran & 48.1 & 20 & 40 & - \\
Tomato pomace & - & 60 & 120 & 180 \\
Calcium soap & 15 & 15 & - & - \\
Calcium carbonate & 5 & 5 & 5 & 5 \\
Mineral/vitamine premix & 5 & 5 & 5 & 5 \\
\hline Chemical composition & & & & \\
Dry matter & 903 & 903 & 902 & 905 \\
Organic matter & 945 & 957 & 969 & 970 \\
Crude protein & 145 & 145 & 145 & 145 \\
Neutral detergent fiber & 245 & 242 & 245 & 250 \\
Acid detergent fiber & 100 & 107 & 111 & 126 \\
Ether extract & 44.8 & 46.2 & 46.3 & 52.2 \\
Non structural & 510 & 524 & 533 & 523 \\
carbohydrates & & & \\
\hline Calculated from analyzed composition of individual feed ingredients. All chemical
\end{tabular}

${ }^{1}$ Calculated from analyzed composition of individual feed ingredients. All chemical fractions are expressed as $\mathrm{g} / \mathrm{kg}$ dry matter, except dry matter ( $\mathrm{g} / \mathrm{kg}$ fresh matter). Nonstructural carbohydrates were calculated as the difference between organic matter and the sum of crude protein, neutral detergent fiber and ether extract. 
All diets were incubated in vitro for $24 \mathrm{~h}$ following the methodology described in Experiment 1, with the exception that the amount of sample was increased to get enough gas for the analysis of $\mathrm{CH}_{4}$ concentration; therefore, $400 \mathrm{mg}$ of each diet was fermented with $40 \mathrm{~mL}$ of the ruminal fluid and culture medium mixture in $120-\mathrm{mL}$ vials. After $8 \mathrm{~h}$ of incubation, gas production was measured and the gas was sampled for $\mathrm{CH}_{4}$ analyses as described in Experiment 1. Immediately, $1 \mathrm{~mL}$ of each vial content was taken using an insulin syringe, mixed with $1 \mathrm{~mL}$ of $0.5 \mathrm{M} \mathrm{HCl}$, and stored at $-20^{\circ} \mathrm{C}$ for VFA and $\mathrm{NH}_{3}-\mathrm{N}$ analyses. After $24 \mathrm{~h}$, the gas produced and the $\mathrm{pH}$ of the vials' contents were measured and samples for $\mathrm{CH}_{4}, \mathrm{VFA}$ and $\mathrm{NH}_{3}-\mathrm{N}$ analyses were taken. Four replicates per diet were obtained by using the ruminal fluid from each sheep independently as inoculum.

\section{V.2.4. Chemical analyses}

Chemical composition of TP samples and feed ingredients of experimental diets were analyzed using the Association of Official Analytical Chemists (AOAC, 2005) procedures for DM (ID 934.01), ash (ID 048.13), and EE (ID 945.16). Concentrations of NDF, ADF, and lignin were determined following the procedures of Van Soest et al. (1991) and Robertson and Van Soest (1981), respectively, using an ANKOM220 Fiber Analyzer unit (ANKOM Technology Corporation, Fairport, NY, USA). Sodium sulphite and $\alpha$-amylase were used in the sequential analysis of NDF, ADF, and lignin and ash-free values are reported. Nitrogen was measured by the Dumas combustion method employing a Leco FP258 N Analyzer (Leco Corporation, St. Joseph, MI, USA) and the amount of acid detergent insoluble $\mathrm{N}$ (ADIN) was determined by analyzing the $\mathrm{N}$ content in the residue obtained after the treatment of the sample with acid detergent solution. Total sugars and total soluble polyphenols (TSP) were analyzed by colorimetric methods following the anthrone method (Yemm and Willis, 1954) and the Folin-Ciocalteu assay (Singleton and Rossi, 1965), respectively, using an Epoch spectrophotometer (BioTek Instruents Inc., Winooski, VT, USA). Concentrations of $\mathrm{NH}_{3}-\mathrm{N}$ were determined by the phenol-hypochlorite method (Weatherburn, 1967) and those of VFA and $\mathrm{CH}_{4}$ by gas chromatography as described by García-Martínez et al. (2005) and Martínez et al. (2010), respectively. All analyses were performed in duplicate. 


\section{V.2.5. Calculations and statistical analyses}

Data of gas production were fitted with time using the exponential model Gas = PGP $\times\left(1-\mathrm{e}^{(-c \times(\mathrm{t}-\text { Lag }))}\right)$, where PGP is the asymptotic gas production, $c$ is the fractional rate of gas production, Lag is the time before starting gas production, and $t$ is the time of gas measurement. Gas production parameters were estimated using the NLIN procedure of SAS (SAS, 2017) by an iterative least squares procedure. The average gas production rate (AGPR) was calculated as AGPR $=\mathrm{PGP} \times \mathrm{c} \div[2 \times(\ln 2+c$ $\times L a g)]$ and it was defined as the rate between the incubation start and the time at which half PGP is reached. The DM effective degradability (DMED) was estimated as DMED $=[(\mathrm{PDMD} \times \mathrm{c}) \div(\mathrm{c}+\mathrm{Kp})] \times \mathrm{e}^{(-c \times \text { Lag })}$, using a rumen particulate outflow $(\mathrm{Kp})$ of 0.042 per h. Finally, the amount of fermented OM (FOM) was calculated from acetate, propionate, and butyrate production in each vial, as described by Demeyer (1991).

As there were no differences $(\mathrm{P} \geq 0.191)$ in the chemical composition of the TP samples between the 2 processing plants, chemical composition data were analyzed using the PROC GLM of SAS (SAS Institute, Cary, NC, USA) (SAS, 2017) with sampling time as the main effect. Data from Experiment 1 were analyzed as a mixed model with repeated measurements using the PROC MIXED of SAS, in which the effect of sampling time ( 1 to 6 weeks) was considered fixed and that of the inoculum was considered random. Data from Experiment 2 were analyzed as a mixed model, with the effect of the diet being fixed and that of the inoculum being random. Nonorthogonal polynomial contrasts were used to test for linear and quadratic effects of TP inclusion. Significance was declared at $\mathrm{P}<0.05$, whereas $\mathrm{P}<0.10$ values were considered as a trend. When a significant effect of sampling time was detected, means were compared by Tukey's test. Relationships between chemical composition of the TP samples and either gas production or fermentation parameters were assessed by linear regression using the PROC CORR of SAS (SAS, 2017). 


\section{V.3. Results}

V.3.1. Chemical composition of tomato pomace samples, in vitro fermentation, and intestinal digestibility of crude protein

Chemical composition of TP (Table 16) was relatively unchanged over the sampling period and only lignin and EE contents varied significantly $(\mathrm{P} \leq 0.017)$ with time; in general, lignin increased with advancing time, whereas EE decreased. Both NDF and ADF contents tended ( $\mathrm{P}=0.096$ and 0.063 , respectively) to be greater in the last weeks of sampling compared with the first sampling week. Dry matter, total sugars, and TSP were the most variable fractions, with coefficients of variation (CV) of $21.9 \%$, $20.1 \%$, and $25.1 \%$, respectively (results not shown), whereas the rest of the analyzed fractions showed a CV lower than 10\%, except ADIN and EE (15.4\% and 18.1\%, respectively).

As shown in Table 17, there were differences $(\mathrm{P} \leq 0.043)$ among TP samples taken at different times in all gas production and in vitro fermentation parameters, except for the fractional gas production rate, $\mathrm{Lag}, \mathrm{NH}_{3}$ concentrations, and $\mathrm{CH}_{4}$ production, although a trend $(\mathrm{P} \leq 0.095)$ was detected for lag and $\mathrm{CH}_{4}$ production. Fermentation data indicated that TP samples taken at the end of the campaign were less degradable than the rest of samples.

Values of 16-h in situ degradability of DM ranged from 488 to $540 \mathrm{~g} / \mathrm{kg}$, and decreased $(\mathrm{P}=0.005)$ as sampling time advanced (Table 18). In contrast, $16 \mathrm{~h}$ in situ degradability of CP, IDCP, and total CP digestibility values did not change $(\mathrm{P} \geq 0.190)$ over the sampling period.

Table 19 shows the correlation coefficients between chemical composition and gas production parameters (PGP and AGPR), DMED, some fermentation parameters, in situ rumen degradability of DM and CP, and IDCP of TP samples. Organic matter was the chemical fraction more closely correlated $(r \geq 0.860 ; \mathrm{P}<0.001)$ with PGP, AGPR, and total VFA production; ADF was the only fraction significantly correlated $(\mathrm{P}=$ 0.030) with $\mathrm{CH}_{4}$ production. In situ DM degradability showed negative correlations ( $\mathrm{r} \geq$ $-0.699 ; \mathrm{P} \leq 0.011)$ with NDF, ADF, and lignin, whereas in situ CP degradability was negatively correlated with $\mathrm{ADF}(\mathrm{r}=-0.724 ; \mathrm{P}=0.008)$ and positively with $\mathrm{CP}$ content 
$(\mathrm{r}=0.796 ; \mathrm{P}=0.002)$. The IDCP was negatively affected by TSP content $(\mathrm{r}=-0.744 ; \mathrm{P}$ $=0.006)$, and total $\mathrm{CP}$ digestibility was positively correlated with $\mathrm{CP}$ content $(\mathrm{r}=0.790$; $\mathrm{P}=0.002)$.

\section{V.3.2. In vitro fermentation of diets containing tomato pomace}

There were no differences ( $\mathrm{P} \leq$ 0.175) among diets (Table 20) in PGP, Lag, AGPR, and DMED values, but the fractional rate of gas production was linearly $(\mathrm{P}=$ $0.016)$ and quadratically $(\mathrm{P}=0.015)$ augmented with increasing $\mathrm{TP}$ amounts in the diet. Total VFA production at $8 \mathrm{~h}$ of incubation was not affected $(\mathrm{P} \geq 0.161)$ by the inclusion of TP, but after $24 \mathrm{~h}$ of incubation a linear increase $(\mathrm{P}=0.029)$ in total VFA production was observed. At $8 \mathrm{~h}$ of incubation, the VFA profile was modified by TP inclusion and there was an increase in molar proportion of acetate (quadratic; $\mathrm{P}=0.038$ ) and propionate (linear; $\mathrm{P}=0.007)$ and a linear decrease in the proportion of butyrate $(\mathrm{P}=$ 0.009 ) and minor VFA (calculated as the sum of isobutyrate, isovalerate, and valerate; $\mathrm{P}$ $=0.002)$ as TP increased. However, after $24 \mathrm{~h}$ of incubation, only a linear increase $(\mathrm{P}=$ $0.002)$ in propionate proportion and a linear decrease $(\mathrm{P}=0.002)$ in the proportion of minor VFA were observed. As a consequence, acetate/propionate ratios decreased linearly at both incubation times $(\mathrm{P}=0.039$ and 0.007 at 8 and $24 \mathrm{~h}$, respectively). Concentrations of $\mathrm{NH}_{3}-\mathrm{N}$ decreased linearly at $8 \mathrm{~h}(\mathrm{P}=0.049)$ with increasing amounts of TP in the diet and a trend $(\mathrm{P}=0.066)$ was detected after $24 \mathrm{~h}$ of incubation. Including TP in the diet did not affect $\mathrm{CH}_{4}$ production at any time $(\mathrm{P} \geq 0.194)$, but a linear reduction $(\mathrm{P}=0.047)$ of $\mathrm{CH}_{4} / \mathrm{VFA}$ ratio was observed at $8 \mathrm{~h}$ of incubation; however, this effect disappeared after $24 \mathrm{~h}$ of incubation. 
Table 16. Chemical composition ( $\mathrm{g} / \mathrm{kg}$ dry matter (DM) unless stated otherwise) of tomato pomace samples taken from two processing plants at weekly intervals during the tomato harvesting campaign.

\begin{tabular}{|c|c|c|c|c|c|c|c|c|c|}
\hline \multirow{2}{*}{ Item } & \multicolumn{6}{|c|}{ Sampling Time (Weeks) } & \multirow{2}{*}{ Average } & \multirow{2}{*}{ SEM $^{1}$} & \multirow{2}{*}{ P-Value } \\
\hline & 1 & 2 & 3 & 4 & 5 & 6 & & & \\
\hline $\mathrm{DM}(\mathrm{g} / \mathrm{kg})$ & 260 & 277 & 244 & 276 & 231 & 291 & 263 & 36.2 & 0.841 \\
\hline Organic matter & 961 & 965 & 957 & 962 & 963 & 970 & 963 & 3.5 & 0.35 \\
\hline Crude protein & 173 & 150 & 160 & 158 & 159 & 161 & 160 & 8.4 & 0.623 \\
\hline Acid detergent insoluble N (ADIN) & 2.22 & 1.58 & 2.07 & 2.08 & 2.12 & 2.24 & 2.05 & 0.146 & 0.126 \\
\hline Neutral detergent fiber & 541 & 574 & 565 & 589 & 576 & 584 & 572 & 9.5 & 0.096 \\
\hline Acid detergent fiber & 408 & 442 & 434 & 466 & 442 & 442 & 439 & 9.4 & 0.063 \\
\hline Acid detergent lignin & $217^{\mathrm{a}}$ & $244^{a b}$ & $229^{\mathrm{ab}}$ & $259^{b}$ & $246^{\mathrm{ab}}$ & $270^{b}$ & 244 & 7.2 & 0.017 \\
\hline Ether extract & $107^{\mathrm{c}}$ & $101^{\mathrm{bc}}$ & $76.5^{\mathrm{ab}}$ & $69.7^{\mathrm{a}}$ & $81.9^{a b}$ & $84.4^{\mathrm{ab}}$ & 82.7 & 5.36 & 0.015 \\
\hline Total sugars & 123 & 124 & 134 & 108 & 113 & 127 & 122 & 15.4 & 0.856 \\
\hline Total soluble polyphenols & 4.05 & 4.36 & 3.42 & 3.40 & 3.05 & 2.55 & 3.47 & 0.408 & 0.137 \\
\hline Potential DM degradability & 595 & 574 & 614 & 583 & 595 & 519 & 580 & 27 & 0.323 \\
\hline
\end{tabular}

${ }^{a b c}$ Within each variable, mean values with different superscripts differ $(\mathrm{P}<0.05) .{ }^{1} \mathrm{SEM}=$ standard error of the mean. 
Table 17. Gas production kinetics and fermentation parameters of tomato pomace samples taken from two processing plants at weekly intervals during the tomato harvesting campaign and samples.

\begin{tabular}{|c|c|c|c|c|c|c|c|c|c|}
\hline \multirow{2}{*}{ Item } & \multicolumn{6}{|c|}{ Sampling Time (Weeks) } & \multirow{2}{*}{ Average } & \multirow{2}{*}{ SEM $^{1}$} & \multirow{2}{*}{ P-Value } \\
\hline & 1 & 2 & 3 & 4 & 5 & 6 & & & \\
\hline \multicolumn{10}{|l|}{ Gas production parameters ${ }^{2}$} \\
\hline PGP (mL/g dry matter (DM)) & $199^{\mathrm{a}}$ & $201^{\mathrm{ab}}$ & $226^{\mathrm{b}}$ & $211^{\mathrm{ab}}$ & $210^{\mathrm{ab}}$ & $187^{\mathrm{a}}$ & 206 & 5.9 & 0.001 \\
\hline$c(\% / \mathrm{h})$ & 7.28 & 7.17 & 6.97 & 7.04 & 7.17 & 6.88 & 7.09 & 0.181 & 0.316 \\
\hline $\operatorname{Lag}(\mathrm{h})$ & 2.33 & 2.63 & 2.33 & 2.50 & 2.42 & 2.48 & 2.45 & 0.130 & 0.064 \\
\hline $\operatorname{AGPR}(\mathrm{mL} / \mathrm{h})$ & $8.51^{\mathrm{ab}}$ & $8.32^{a b}$ & $9.39^{\mathrm{b}}$ & $8.81^{\mathrm{b}}$ & $8.73^{b}$ & $7.48^{\mathrm{a}}$ & 8.54 & 0.262 & 0.001 \\
\hline DMED $(\mathrm{g} / \mathrm{kg})$ & $324^{\mathrm{c}}$ & $305^{\mathrm{bc}}$ & $332^{\mathrm{c}}$ & $313^{\mathrm{b}}$ & $320^{\mathrm{c}}$ & $276^{\mathrm{a}}$ & 312 & 7.3 & $<0.001$ \\
\hline $\begin{array}{l}\text { Fermentation parameters }{ }^{3} \\
\mathrm{pH}\end{array}$ & $6.81^{\mathrm{ab}}$ & $6.80^{\mathrm{ab}}$ & $6.76^{\mathrm{b}}$ & $6.75^{\mathrm{b}}$ & $6.79^{\mathrm{ab}}$ & $6.83^{\mathrm{a}}$ & 6.79 & 0.015 & 0.004 \\
\hline $\begin{array}{l}\text { Total volatile fatty acids (VFA; } \\
\mathrm{mmol} / \mathrm{g} \mathrm{DM})\end{array}$ & $6.21^{\mathrm{ab}}$ & $6.34^{b}$ & $6.52^{b}$ & $6.37^{b}$ & $6.41^{b}$ & $5.78^{\mathrm{a}}$ & 6.27 & 0.250 & 0.004 \\
\hline \multicolumn{10}{|l|}{ Molar proportions (mol/100 mol) } \\
\hline Acetate & $66.8^{\mathrm{ab}}$ & $65.9^{\mathrm{a}}$ & $66.3^{\mathrm{ab}}$ & $66.3^{\mathrm{ab}}$ & $67.0^{\mathrm{b}}$ & $66.8^{\mathrm{ab}}$ & 66.5 & 0.23 & 0.007 \\
\hline Propionate & $23.0^{\mathrm{ab}}$ & $23.5^{\mathrm{ab}}$ & $23.6^{\mathrm{b}}$ & $23.5^{\mathrm{ab}}$ & $23.0^{a b}$ & $22.7^{\mathrm{a}}$ & 23.2 & 0.21 & 0.014 \\
\hline Butyrate & 7.17 & 7.41 & 7.44 & 7.36 & 7.23 & 7.37 & 7.33 & 0.068 & 0.043 \\
\hline Minor VFA & $2.98^{\mathrm{ab}}$ & $3.14^{\mathrm{b}}$ & $2.64^{\mathrm{a}}$ & $2.82^{\mathrm{ab}}$ & $2.78^{a b}$ & $3.10^{\mathrm{b}}$ & 2.91 & 0.105 & 0.011 \\
\hline Acetate/propionate $(\mathrm{mol} / \mathrm{mol})$ & $2.91^{\mathrm{ab}}$ & $2.80^{\mathrm{a}}$ & $2.81^{\mathrm{ab}}$ & $2.83^{\mathrm{ab}}$ & $2.93^{a b}$ & $2.95^{b}$ & 2.87 & 0.035 & 0.009 \\
\hline $\mathrm{NH}_{3}(\mathrm{mg} / \mathrm{L})$ & 173 & 158 & 155 & 156 & 159 & 155 & 159 & 8.2 & 0.608 \\
\hline $\mathrm{CH}_{4}(\mathrm{~mL} / \mathrm{g} \mathrm{DM})$ & $65.2^{\mathrm{ab}}$ & $63.8^{\mathrm{b}}$ & $75.0^{\mathrm{b}}$ & $76.3^{a}$ & $65.0^{\mathrm{ab}}$ & $61.8^{\mathrm{a}}$ & 67.9 & 4.02 & 0.060 \\
\hline $\mathrm{CH}_{4} / \mathrm{VFA}(\mathrm{mL} / \mathrm{mmol})$ & 10.1 & 9.33 & 10.3 & 10.6 & 9.91 & 10.6 & 10.1 & 0.346 & 0.112 \\
\hline
\end{tabular}

$\mathrm{CH}_{4} / \mathrm{VFA}(\mathrm{mL} / \mathrm{mmol})$

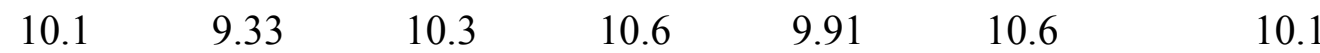

0.346

0.112

Within each parameter, mean values with different superscripts differ $(\mathrm{P}<0.05)$. ${ }^{1}$ SEM: Standard error of the mean. ${ }^{2}$ PGP: Asymptotic gas production $(\mathrm{mL} / \mathrm{g} \mathrm{DM}) ; c$ : Fractional rate of gas production $(\% / \mathrm{h}) ;$ Lag: Time before starting gas production; AGPR: Average gas production rate; DMED: Dry matter effective degradability calculated for a rumen particulate outflow of $4 \% / \mathrm{h} .{ }^{3}$ Minor VFA: Calculated as the sum of isobutyrate, isovalerate and valerate. 
Table 18. In situ rumen degradability of dry matter (DM) and crude protein (CP) after $16 \mathrm{~h}$ of incubation, in vitro intestinal digestibility of CP (IDCP), and total $\mathrm{CP}$ digestibility of tomato pomace samples taken from two processing plants at weekly intervals during the tomato harvesting campaign.

\begin{tabular}{|c|c|c|c|c|c|c|c|c|c|}
\hline \multirow{2}{*}{ Item } & \multicolumn{6}{|c|}{ Sampling Time (Weeks) } & \multirow{2}{*}{ Average } & \multirow{2}{*}{ SEM $^{1}$} & \multirow{2}{*}{ P-Value } \\
\hline & 1 & 2 & 3 & 4 & 5 & 6 & & & \\
\hline In situ degradability of DM (g/kg) & $540^{b}$ & $523^{\mathrm{ab}}$ & $530^{\mathrm{ab}}$ & $488^{\mathrm{a}}$ & $492^{\mathrm{a}}$ & $489^{\mathrm{a}}$ & 510 & 11.0 & 0.005 \\
\hline In situ degradability of CP $(\mathrm{g} / \mathrm{kg})$ & 563 & 515 & 492 & 511 & 502 & 478 & 510 & 26.6 & 0.344 \\
\hline IDCP $(\mathrm{g} / \mathrm{kg})$ & 450 & 430 & 467 & 466 & 475 & 467 & 459 & 19.0 & 0.593 \\
\hline Total CP digestibility (g/kg) & 761 & 730 & 726 & 739 & 741 & 722 & 737 & 10.7 & 0.190 \\
\hline
\end{tabular}

${ }^{\mathrm{ab}}$ Within each parameter, mean values with different superscripts differ $(\mathrm{P}<0.05)$. ${ }^{1}$ SEM: Standard error of the mean 
Table 19. Correlation matrix (Pearson coefficient and P-values in brackets; $n=12$ ) of chemical composition of tomato pomace samples with gas production parameters, dry matter effective degradability (DMED), fermentation parameters measured in 24-h in vitro incubations, in situ rumen degradability of dry matter (DM) and crude protein (CP) after $16 \mathrm{~h}$ of incubation, and in vitro intestinal digestibility of $\mathrm{CP}$ (only $\mathrm{P}<0.10$ values are shown) ${ }^{1}$.

\begin{tabular}{|c|c|c|c|c|c|c|c|c|}
\hline Item & $\mathbf{O M}^{2}$ & NDF & ADF & Lignin & Lignin/NDF & $\mathbf{N}$ & $\mathbf{E E}$ & TSP \\
\hline \multicolumn{9}{|l|}{ Gas production parameters $^{3}$} \\
\hline PGP & $\begin{array}{c}0.860 \\
(<0.001)\end{array}$ & & $\begin{array}{c}0.552 \\
(0.063)\end{array}$ & & $\begin{array}{l}-0.590 \\
(0.044)\end{array}$ & & & \\
\hline AGPR & $\begin{array}{c}-0.892 \\
(<0.001)\end{array}$ & & & $\begin{array}{l}-0.646 \\
(0.023)\end{array}$ & & & & \\
\hline DMED & $\begin{array}{c}-0.684 \\
(0.014) \\
\end{array}$ & & & $\begin{array}{l}-0.770 \\
(0.003) \\
\end{array}$ & $\begin{array}{l}-0.741 \\
(0.006)\end{array}$ & & & \\
\hline \multicolumn{9}{|l|}{ Fermentation parameters } \\
\hline Total volatile fatty acid (VFA) production & $\begin{array}{c}-0.857 \\
(<0.001)\end{array}$ & & $\begin{array}{c}0.549 \\
(0.064)\end{array}$ & & $\begin{array}{l}-0.613 \\
(0.034)\end{array}$ & & & \\
\hline $\mathrm{CH}_{4}$ & $\begin{array}{c}-0.789 \\
(0.002) \\
\end{array}$ & & $\begin{array}{c}0.617 \\
(0.033) \\
\end{array}$ & & & & & \\
\hline \multicolumn{9}{|c|}{ In situ degradability and in vitro intestinal digestibility } \\
\hline In situ rumen DM degradability & & $\begin{array}{l}-0.838 \\
(0.001)\end{array}$ & $\begin{array}{l}-0.726 \\
(0.008)\end{array}$ & $\begin{array}{l}-0.699 \\
(0.011)\end{array}$ & & & $\begin{array}{c}0.600 \\
(0.039)\end{array}$ & $\begin{array}{c}0.559 \\
(0.059)\end{array}$ \\
\hline In situ rumen CP degradability & & & $\begin{array}{l}-0.724 \\
(0.008)\end{array}$ & & & $\begin{array}{c}0.796 \\
(0.002)\end{array}$ & & \\
\hline In vitro intestinal digestibility of $\mathrm{CP}$ & & & $\begin{array}{c}0.568 \\
(0.054)\end{array}$ & & & & $\begin{array}{l}-0.511 \\
(0.090)\end{array}$ & $\begin{array}{l}-0.744 \\
(0.006)\end{array}$ \\
\hline Total digestibility of $\mathrm{CP}$ & & & $\begin{array}{l}-0.516 \\
(0.086) \\
\end{array}$ & & & $\begin{array}{c}0.790 \\
(0.002) \\
\end{array}$ & & \\
\hline
\end{tabular}

${ }^{1}$ Total sugars and acid detergent insoluble N (ADIN) were not correlated to any of the analyzed parameters. ${ }^{2}$ OM: Organic matter; NDF: Neutral detergent fiber; ADF: Acid detergent fiber; EE: Ether extract; TSP: Total soluble polyphenols. ${ }^{3}$ PGP: Potential gas production (mL/g dry matter); AGPR: Average gas production rate until it has reached half of PGP $(\mathrm{mL} / \mathrm{h})$; DMED: Calculated for a rumen particulate outflow of $4 \%$ per h $(\%)$. 
Table 20. Gas production parameters and fermentation parameters after 8 and $24 \mathrm{~h}$ of in vitro fermentation of diets containing increased amounts of tomato pomace incubated in batch cultures of mixed rumen microorganisms ${ }^{1}$.

\begin{tabular}{|c|c|c|c|c|c|c|c|}
\hline \multirow{2}{*}{ Item and Incubation Time } & \multirow{2}{*}{ Control } & \multirow{2}{*}{ TP6 } & \multirow{2}{*}{ TP12 } & \multirow{2}{*}{ TP18 } & \multirow{2}{*}{$\operatorname{SEM}^{1}$} & \multicolumn{2}{|c|}{ P-Value } \\
\hline & & & & & & Lineal & Quadratic \\
\hline \multicolumn{8}{|l|}{ Gas production parameters $^{2}$} \\
\hline PGP (mL/g dry matter & 336 & 334 & 326 & 334 & 3.67 & 0.453 & 0.229 \\
\hline$c(\% / \mathrm{h})$ & $4.17^{\mathrm{a}}$ & $4.62^{b}$ & $4.73^{b}$ & $4.58^{\mathrm{b}}$ & 0.121 & 0.016 & 0.015 \\
\hline $\operatorname{Lag}(\mathrm{h})$ & 1.63 & 1.42 & 2.03 & 1.90 & 0.30 & 0.325 & 0.894 \\
\hline AGPR mL/h & 9.16 & 10.1 & 9.74 & 9.76 & 0.37 & 0.416 & 0.236 \\
\hline $\operatorname{DMED}(\%)$ & 33.4 & 35.4 & 34.1 & 33.3 & 0.73 & 0.983 & 0.175 \\
\hline \multicolumn{8}{|c|}{ Fermentation parameters at $8 \mathrm{~h}$ incubation ${ }^{3}$} \\
\hline Total VFA (mmol/g DM) & 3.47 & 3.44 & 3.52 & 3.62 & 0.075 & 0.161 & 0.430 \\
\hline \multicolumn{8}{|c|}{ Molar proportions $(\mathrm{mol} / 100 \mathrm{~mol})$} \\
\hline Acetate (Ac) & $57.7^{\mathrm{a}}$ & $58.3^{\mathrm{b}}$ & $58.1^{\mathrm{b}}$ & $58.2^{\mathrm{b}}$ & 0.12 & 0.059 & 0.038 \\
\hline Propionate (Pr) & $23.9^{\mathrm{a}}$ & $23.9^{\mathrm{a}}$ & $24.4^{\mathrm{b}}$ & $24.4^{\mathrm{b}}$ & 0.13 & 0.007 & 0.971 \\
\hline Butyrate & $15.0^{\mathrm{b}}$ & $14.6^{\mathrm{a}}$ & $14.4^{\mathrm{a}}$ & $14.4^{\mathrm{a}}$ & 0.09 & 0.009 & 0.053 \\
\hline Minor VFA & $3.37^{\mathrm{c}}$ & $3.18^{b}$ & $3.08^{\mathrm{a}}$ & $3.04^{\mathrm{a}}$ & 0.043 & 0.002 & 0.095 \\
\hline $\mathrm{Ac} / \operatorname{Pr}(\mathrm{mol} / \mathrm{mol})$ & $2.46^{\mathrm{ac}}$ & $2.48^{\mathrm{ac}}$ & $2.42^{\mathrm{ab}}$ & $2.42^{\mathrm{a}}$ & 0.022 & 0.039 & 0.405 \\
\hline $\mathrm{NH}_{3}-\mathrm{N}(\mathrm{mg} / \mathrm{L})$ & $185^{b}$ & $182^{\mathrm{ab}}$ & $181^{\mathrm{ab}}$ & $178^{\mathrm{a}}$ & 2.1 & 0.049 & 0.815 \\
\hline $\mathrm{CH}_{4}(\mathrm{~mL} / \mathrm{g} \mathrm{DM})$ & 18.5 & 18.0 & 18.0 & 18.4 & 0.36 & 0.901 & 0.296 \\
\hline $\mathrm{CH}_{4} / \mathrm{VFA}(\mathrm{mL} / \mathrm{mmol})$ & $5.34^{\mathrm{b}}$ & $5.24^{\mathrm{ab}}$ & $5.16^{\mathrm{ab}}$ & $5.09^{\mathrm{a}}$ & 0.082 & 0.047 & 0.836 \\
\hline FOM (mg/g) & 332 & 328 & 334 & 345 & 7.2 & 0.178 & 0.325 \\
\hline \multicolumn{8}{|c|}{ Fermentation parameters at $24 \mathrm{~h}$ incubation ${ }^{3}$} \\
\hline $\mathrm{pH}$ & $6.71^{\mathrm{c}}$ & $6.71^{\mathrm{c}}$ & $6.67^{\mathrm{b}}$ & $6.63^{\mathrm{a}}$ & 0.011 & 0.003 & 0.222 \\
\hline Total VFA (mmol/g DM) & $6.82^{\mathrm{a}}$ & $6.84^{\mathrm{a}}$ & $6.91^{\mathrm{ab}}$ & $6.99^{\mathrm{b}}$ & 0.05 & 0.029 & 0.61 \\
\hline \multicolumn{8}{|c|}{ Molar proportions (mol/100 mol) } \\
\hline Acetate (Ac) & 58.6 & 58.8 & 58.4 & 58.5 & 0.07 & 0.150 & 0.569 \\
\hline Propionate (Pr) & $19.4^{\mathrm{a}}$ & $19.6^{\mathrm{a}}$ & $20.1^{\mathrm{b}}$ & $20.1^{\mathrm{b}}$ & 0.14 & 0.002 & 0.594 \\
\hline Butyrate & 17.5 & 17.4 & 17.5 & 17.5 & 0.1 & 0.705 & 0.576 \\
\hline Minor VFA & $4.40^{\mathrm{b}}$ & $4.14^{\mathrm{b}}$ & $4.10^{\mathrm{b}}$ & $3.96^{\mathrm{a}}$ & 0.071 & 0.002 & 0.421 \\
\hline $\mathrm{Ac} / \operatorname{Pr}(\mathrm{mol} / \mathrm{mol})$ & $3.08^{b}$ & $3.05^{\mathrm{b}}$ & $2.96^{\mathrm{a}}$ & $2.96^{\mathrm{a}}$ & 0.022 & 0.007 & 0.465 \\
\hline $\mathrm{NH}_{3}-\mathrm{N}(\mathrm{mg} / \mathrm{L})$ & $284^{\mathrm{b}}$ & $270^{\mathrm{b}}$ & $271^{b}$ & $269^{\mathrm{a}}$ & 4.8 & 0.066 & 0.215 \\
\hline $\mathrm{CH}_{4}$ (mL/g dry matter) & 43.1 & 41.8 & 41.0 & 42.4 & 1.38 & 0.658 & 0.371 \\
\hline $\mathrm{CH}_{4} / \mathrm{VFA}(\mathrm{mL} / \mathrm{mmol})$ & 6.33 & 6.11 & 5.93 & 6.05 & 0.213 & 0.312 & 0.450 \\
\hline FOM $(\mathrm{mg} / \mathrm{g})$ & $660^{a}$ & $661^{\mathrm{a}}$ & $668^{a b}$ & $680^{\mathrm{b}}$ & 4.3 & 0.007 & 0.293 \\
\hline
\end{tabular}

${ }^{a b c}$ Within each parameter, mean values with different superscripts differ $(\mathrm{P}<0.05) .{ }^{1}$ Control, TP6, TP12, and TP18 diets contained 0,60, 120, and $180 \mathrm{~g}$ of tomato pomace per kg, respectively (fresh matter basis). ${ }^{2}$ PGP: Asymptotic gas production; $c$ : Fractional rate of gas production; Lag: Time before starting gas production; AGPR: Average gas production rate; DMED: Dry matter effective degradability calculated for a rumen particulate outflow of $4 \% / \mathrm{h} .{ }^{3} \mathrm{VFA}$ : Volatile fatty acids; minor VFA were calculated as the sum of isobutyrate, isovalerate, and valerate; FOM: Fermented organic matter calculated from acetate, propionate, and butyrate production as described by Demeyer (1991). 


\section{V.4. Discussion}

V.4.1. Chemical composition, in vitro fermentation, and in vitro intestinal digestibility of tomato pomace samples

Chemical composition of TP was within the range of values previously reported (Bakshi et al., 2016; Abbeddou et al., 2011; Denek and Can, 2006), although other studies (Fondevila et al., 1994; Gasa et al., 1988) reported lower lignin and greater EE values. Tomato pomace is a fibrous by-product with a relatively high content of CP and EE. As reported by others (Hetzroni et al., 2011; Del Valle et al., 2006; Abdel-Rahman, 1982), most of fiber and CP comes from the peel fraction of TP, whereas seeds contain most of ash and EE; therefore the relative proportions of peels and seeds in TP can help to explain the observed differences in lignin and EE due to sampling time in the present study, as well as variations in chemical composition among studies (Hetzroni et al., 2011). In addition, chemical composition of tomato fruits has been reported to be highly variable, depending on factors such as cultivars, crop conditions, origin, etc. (Del Valle et al., 2006), which also contributes to variability in TP composition. Additional factors, such as tomato industrial processing characteristics, can increase variability. However, in the present study, there were no differences in any chemical fraction between the TP samples from the two processing plants, which might be due to a similar processing type in both of them. Finally, the application of high temperatures during tomato processing may result in the formation of indigestible compounds via the Maillard reactions between sugar aldehyde groups and free amino groups (Broderick et al., 2000) that resulted in high ADIN values (16\%-26\%) reported in some studies (Rahbarpour et al., 2012; Weiss et al., 1997; Fondevila et al., 1994). However, ADIN concentrations in our study were relatively low, ranging from $6.6 \%$ to $8.8 \%$ of total N. Differences in the ADIN content could be attributed to variability in tomato fruits or processing (Del Valle et al., 2006), but also to different processing temperatures.

Despite the relatively low variability in TP chemical composition observed in our study, there were some differences between sampling times in PGP, AGPR, and DMED, with samples taken at week 6 having lower values than those taken at week 2. Abbeddou et al. (2011) pointed out that CP and non-structural carbohydrates of TP are easy and rapidly degraded, whereas NDF has low degradability. The low Lag values $(\leq$ 
$2.63 \mathrm{~h}$ ) agree with this observation. These results indicate that TP was rapidly fermented in vitro.

Values of total VFA production agree well with gas production parameters, as TP samples taken at week 6 had lower values than the rest of the samples, except those taken at week 1. Despite the fact that there were significant effects of sampling period on molar proportions of all individual VFA, changes were of minor importance and the VFA profile remained relatively constant over the sampling period.

The main fatty acids present in TP are oleic and linoleic acids (Romano et al., 2010) and the unsaturated fatty acids which are produced by the hydrolysis of triglycerides are toxic to the fibrolytic bacteria (Maia et al., 2007). However, the lack of correlation $(\mathrm{P} \geq 0.339)$ between $\mathrm{EE}$ content and any gas production or in vitro fermentation parameter indicates that EE had no negative effect on TP fermentation, despite the fact that its concentrations were greater than the maximal level of $60 \mathrm{~g}$ of fat per $\mathrm{kg}$ of $\mathrm{DM}$ recommended in the diet of ruminants to avoid reductions in fiber digestibility (NRC, 2001). There were some differences between samples in $\mathrm{CH}_{4}$ production, but these differences disappeared when the $\mathrm{CH}_{4} /$ total VFA ratio was calculated.

Although OM content showed low variability among TP samples, it was the chemical fraction more closely related to gas production parameters and VFA and $\mathrm{CH}_{4}$ production, with the correlation being negative; this might be explained because of the close relationship between $\mathrm{OM}$ and the lignin/NDF ratio $(\mathrm{r}=0.830 ; \mathrm{P}<0.001)$, as lignification is one of the main factors limiting NDF degradability (Van Soest, 1994). In fact, the lignin/NDF ratio was negatively correlated with PGP, DMED, and total VFA, indicating that NDF lignification was a major factor involved in the differences observed in fermentation parameters.

Values of $16 \mathrm{~h}$ in situ rumen DM degradability were similar to those reported by Abbeddou et al. (2011) and Gasa et al. (1988) after 16 and 24 h of ruminal incubation, respectively (476 and $471 \mathrm{~g} / \mathrm{kg}$ ), but greater than the $389 \mathrm{~g} / \mathrm{kg}$ reported by Fondevila et al. (1994) after $24 \mathrm{~h}$ of incubation in the rumen. Values of in situ degradability of CP were greater than the $406 \mathrm{~g} / \mathrm{kg}$ reported by Fondevila et al. (1994) for $24 \mathrm{~h}$ of incubation, but lower than the $649 \mathrm{~g} / \mathrm{kg}$ reported by Abbeddou et al. (2011) for $16 \mathrm{~h}$ of 
incubation. Differences among studies are probably due to variability in TP chemical composition, but may be also related to the performance of the in situ procedure which is influenced by many factors, such as animals, diet, incubation procedure, etc. (Yuangklang et al., 2010). In situ degradability of both DM and CP was negatively correlated with ADF content, reflecting the low degradability of this fraction, which is the main constituent of fiber in TP; this might also restrict the access of microorganisms to protein.

The values of IDCP revealed that only nearly half of the CP undegraded in the rumen can be digested in the intestine, and total CP digestibility reached $737 \mathrm{~g} / \mathrm{kg}$ as average. These values agree with previous observations reporting lower protein digestibility in TP compared with protein concentrates such as soybean meal (Yuangklang et al., 2010; Fondevila et al., 1994). The positive correlation of IDCP with ADF fraction is in accordance with the observation that intestinal digestibility of CP increases as rumen degradability of CP decreases (González et al., 2018); this would explain the fact that ADF was negatively correlated with in situ $\mathrm{CP}$ degradability and positively with IDCP. The negative correlation between IDCP and TSP content may indicate that TSP formed less digestible complexes with dietary proteins.

\section{V.4.2. In vitro fermentation of diets containing tomato pomace}

The increased fractional rates of gas production indicate that diets including TP were fermented more rapidly than the control diet, which is in agreement with the increased VFA productions observed at $24 \mathrm{~h}$ of incubation, although only TP18 diet showed significant differences with the control diet. These results are consistent with the lower amounts of barley straw in the TP-diets than in the control diet, as barley straw is slowly degraded in the rumen and greater VFA productions and FOM were observed for the TP-diets after $24 \mathrm{~h}$ of incubation. Including TP in the diet also changed the VFA profile. Our results are in agreement with those of Soto et al. (2015), who observed that in vitro molar proportion of acetic acid increased and butyric and minor VFA proportions decreased when tomato fruit wastes were included in the diet. Similarly, Arco-Pérez et al. (2017) reported an increase in propionate proportions and a decrease in the acetate/propionate ratio in the rumen of goats receiving tomato silage compared with those fed a control diet. 
The reduced $\mathrm{NH}_{3}-\mathrm{N}$ concentrations observed with increasing TP levels could be due to the lower degradation of TP protein, as $\mathrm{NH}_{3}-\mathrm{N}$ is one of the main final products of protein degradation in the rumen. The decreased proportions of minor VFA as the level of TP in the diet increased are consistent with this hypothesis, but $\mathrm{NH}_{3}-\mathrm{N}$ concentrations were adequate for rumen microorganism growth in all diets (Satter and Slyter, 1974). Tomato pomace replaced increased amounts of soybean meal in the experimental diets and rumen degradability of TP has been reported to be lower than that of soybean meal (Fondevila et al., 1994), which would indicate greater bypass protein in TP than in soybean meal. According to Drouliscos (1976), the essential amino acids profile in TP protein is similar to that in soybean meal, but the low values of IDCP observed in our study indicate that about half of the protein reaching the small intestine may not be digested, whereas intestinal digestibility of soybean meal is greater than 90\% (Satter and Slyter, 1974). In agreement with these results, Yuangklang et al. (2010) and Fondevila et al. (1994) reported a significant decrease in CP digestibility when replacing soybean meal by TP in the diet of lambs and beef cattle, respectively.

Although some studies have shown that the inclusion of tomato fruit wastes in the diet reduced $\mathrm{CH}_{4}$ emission both in goats (Arcos-Pérez et al., 2017; Romero-Huelva and Molina-Alcaide, 2013; Romero-Huelva et al., 2012) and in in vitro fermentations (Romero-Huelva et al., 2013), no changes in $\mathrm{CH}_{4}$ production were observed in our study. The anti-methanogenic mechanisms of tomato fruit ingredients remain yet unknown (Arcos-Pérez et al., 2017), but either the extraction of the bioactive compounds during the industrial processing of tomato or their destruction by the heat applied in the process might help to explain the lack of anti-methanogenic properties of TP. The reduction of the $\mathrm{CH}_{4} /$ total VFA ratio observed in TP-diets after $8 \mathrm{~h}$ of incubation could be due to the fermentation of soluble and rapidly degraded fractions, which also contributed to greater propionate proportions.

\section{V.5. Conclusions}

Tomato pomace is a high-moisture, fibrous by-product, but its dry matter contains a relatively high content of $\mathrm{CP}$ and $\mathrm{EE}$ and it is rapidly fermented in the rumen. Both the chemical composition and in vitro rumen fermentation of TP samples obtained from two processing plants at different times over the tomato campaign presented little 
variability. Crude protein of TP had low degradability in the rumen (average $510 \mathrm{~g} / \mathrm{kg}$ ) indicating a high bypass fraction, but the in vitro intestinal digestibility of the undegraded CP was low (average $459 \mathrm{~g} / \mathrm{kg}$ ). In vitro results indicated that dried TP could be included up to $180 \mathrm{~g} / \mathrm{kg}$ in a high-concentrate diet without negative effects on rumen fermentation. However, TP did not show the anti-methanogenic properties previously reported for fresh tomato wastes, which was attributed to chemical changes produced during tomato processing.

Author Contributions: M.D.C. and E.M.-A. obtained the funding and TP samples; M.D.C. conceived the experiments; C.N.M. and T.d.E. performed the in vitro trials, analyzed the samples, and did data calculations;

C.N.M. did the statistical analysis and wrote the draft; M.D.C. and E.M.-A. provided advice and critically reviewed the manuscript. All authors revised and approved the final manuscript.

Funding: Funding from the Spanish Ministry of Economy and Competitiveness (AGL2016-75322-C2-1-R project) and Junta de Andalucía (P12-AGR-587 project) is gratefully acknowledged.

Acknowledgments: Authors are grateful to Tomates del Guadiana Soc. Coop., PRONAT and Dr. Fermín López for providing the samples used in this study.

Conflicts of Interest: The authors declare no conflict of interest.

References

Abbeddou, S., Rischkowsky, B., Richter, E. K., Hess, H. D., and Kreuzer, M. (2011). Modification of milk fatty acid composition by feeding forages and agro-industrial byproducts from dry areas to Awassi sheep. Journal of Dairy Science 94, 4657-4668.

Abdel-Rahman, A. Y. (1982). The chemical constituents of tomato seeds. Food Chemistry 9, 315-318.

Association of Official Analytical Chemists (AOAC). (2005). Official Methods of Analysis, 18th ed. AOAC International.

Arco-Pérez, A., Ramos-Morales, E., Yáñez-Ruiz, D. R., Abecia, L., and Martín-García, A. I. (2017). Nutritive evaluation and milk quality of including of tomato or olive by- 
products silages with sunflower oil in the diet of dairy goats. Animal Feed Science and Technology 232, 57-70.

Bakshi, M. P. S., Wadhwa, M., and Makkar, H. (2016). Waste to worth: Vegetable wastes as animal feed. CAB Reviews 11, 1-26.

Belverdy, M. S., Alamouti, A. A., Khadem, A. A., González, J., Carro, M. D., Kianmehr, M. H., and Azizi, M. H. (2019). Evaluation of a novel method for ruminal protection of soybean meal protein using different fat sources. Archives of Animal Nutrition 73, 158-169.

Broderick, G. A., Wallace, R. J., and Ørskov, E. R. Control of rate and extent of protein degradation. California, USA, ed. Tsuda, T., Susaki, Y., Kawashima, R. 2000. In "Physiological Aspects of Digestion and Metabolism in Ruminants". pp. 541-592. Academic Press.

Caluya, R. R. (2000). Tomato pomace and rice straw silage for feeding growing cattle. In "Silage Making in the Tropics with Particular Emphasis on Smallholders; FAO Plant Production and Protection Paper 161”. pp 97-98. FAO.

Caluya, R. R., Sair, R. R., Recta, G. M. R., and Balneg, B. B. (2003). Tomato Pomace as Feed for Livestock and Poultry. Don Mariano Marcos Memorial State University, Bacnotan, La Union, Philippines.

Del Valle, M., Cámara, M., and Torija, M. E. (2006). Chemical characterization of tomato pomace. Journal of the Science of Food and Agriculture 86, 1232-1236.

Demeyer, D. Quantitative aspects of microbial metabolism in the rumen and hindgut. Paris, France, ed. Jouany, J. P. 1991. In "Rumen Microbial Metabolism and Ruminant Digestion”. pp. 217-237. INRA Editions.

Denek, N., and Can, A. (2006). Feeding value of wet tomato pomace ensiled with wheat straw and wheat grain for Awassi sheep. Small Ruminant Research 65, 260-265.

Drouliscos, N. J. (1976). Nutritional evaluation of the protein of dried tomato pomace in the rat. British Journal of Nutrition 36, 449-456.

Fondevila, M., Guada, J. A., Gasa, J., and Castrillo, C. (1994). Tomato pomace as a protein supplement for growing lambs. Small Ruminant Research 13, 117-126.

García-Martínez, R., Ranilla, M. J., Tejido, M. L., and Carro, M. D. (2005). Effects of disodium fumarate on in vitro rumen microbial growth, methane production and 
fermentation of diets differing in their forage concentrate ratio. British Journal of Nutrition 94, 71-77.

Gargallo, S., Calsamiglia, S., and Ferret, A. (2006). Technical note: A modified threestep in vitro procedure to determine intestinal digestion of proteins. Journal of Animal Science 84, 2163-2167.

Gasa, J., Castrillo, C., and Guada, J. A. (1988). Nutritive value for ruminants of the canning industry by-products: 1 Tomato pomace and pepper residues. Investigación Agraria, Producción y Sanidad Animales 3, 57-73.

Goering, M. K., and Van Soest, P. J. (1970). Forage Fiber Analysis (Apparatus, Reagents, Procedures and Some Applications). In "Agricultural Handbook; Agriculture Handbook No. 379”. Agricultural Research Services.

González, J., Mouhbi, R., Guevara-González, J. A., and Arroyo, J. M. (2018). Effects of correcting in situ ruminal microbial colonization of feed particles on the relationship between ruminally undegraded and intestinally digested crude protein in concentrate feeds. Journal of the Science of Food and Agriculture 98, 891-895.

Hetzroni, A., Vana, A., and Mizrach, A. (2011). Biomechanical characteristics of tomato fruit peels. Postharvest Biology and Technology 59, 80-84.

Knoblich, M., Anderson, B., and Latshaw, D. (2005). Analyses of tomato peel and seed byproducts and their use as a source of carotenoids. Journal of the Science of Food and Agriculture 85, 1166-1170.

Maia, M. R., Chaudhary, L. C., Figueres, L., and Wallace, R. J. (2007). Metabolism of polyunsaturated fatty acids and their toxicity to the microflora of the rumen. Antonie Van Leeuwenhoek 91, 303-314.

Martínez, M. E., Ranilla, M. J., Tejido, M. L., Ramos, S., and Carro, M. D. (2010). The effect of the diet fed to donor sheep on in vitro methane production and ruminal fermentation of diets of variable composition. Animal Feed Science and Technology 158 126-135.

NRC. (2007). Nutrient Requirements of Small Ruminants: Sheep, Goats, Cervids, and New World Camelids, 6th ed. National Academy Press.

NRC. (2001). Nutrient Requirements of Dairy Cattle, 7th ed. National Academy of Sciences. 
Rahbarpour, A., Palangi, V., Eivazi, P., and Jalili, M. (2012). Calculation of metabolizable protein and energy of tomato pomace by nylon bags and gas production data. The Journal of Experimental Biology 2, 822-825.

Robertson, J. B., and Van Soest, P. J. The detergent system of analysis and its application to human foods. New York, USA, ed. James, W. P. T., Theander, O. 1981. In "The Analysis of Dietary Fiber in Food". pp. 123-142. Marcel Dekker.

Romano, R., Masucci, F., Giordano, A., Spagna-Musso, S., Naviglio, D., and Santini, A. (2010). Effect of tomato by-products in the diet of Comisana sheep on composition and conjugated linoleic acid content of milk fat. International Dairy Journal 20, 858862.

Romero-Huelva, M., Martin-García, I., Nogales, R., and Molina-Alcaide, E. (2013). The effect of feed blocks containing tomato and cucumber by-products on in vitro ruminal fermentation, microbiota, and methane production. Journal of Animal Science 22, 229-237.

Romero-Huelva, M., and Molina-Alcaide, E. (2013). Nutrient utilization, ruminal fermentation, microbial nitrogen flow, microbial abundances, and methane emissions in goats fed diets including tomato and cucumber waste fruits. Journal of Animal Science 91, 914-923.

Romero-Huelva, M., Ramos-Morales, E., and Molina-Alcaide, E. (2012). Nutrient utilization, ruminal fermentation, microbial abundances, and milk yield composition in dairy goats fed diets including tomato and cucumber waste fruits. Journal of Dairy Science 95, 6015-6026.

SAS Institute. (2017). SAS/STAT®Users Guide, Version 9.3. SAS Inst. Inc.

Satter, L. D., and Slyter, L. L. (1974). Effect of ammonia concentration on rumen microbial protein production in vitro. British Journal of Nutrition 32, 199-208.

Singleton, V. L., and Rossi, J. A. (1965). Colorimetry of total phenolics with phosphomolybdic-phosphotungstic acids reagents. American Journal of Enology and Viticulture 16, 144-158.

Soto, E. C., Khelil, H., Carro, M. D., Yáñez-Ruiz, D. R., and Molina-Alcaide, E. (2015). Use of tomato and cucumber waste fruits in goat diets: Effects on rumen fermentation and microbial communities in batch and continuous cultures. The 
Journal of Agricultural Science 153, 3434-3452.

Van Soest, P. J. (1994). Nutritional Ecology of the Ruminant, 2nd ed. pp. 476. Cornell University Press.

Van Soest, P. J., Robertson, J. B., and Lewis, B. A. (1991). Methods for dietary fiber, neutral detergent fiber and nonstarch polysaccharides in relation to animal nutrition. Journal of Dairy Science 74, 3583-3597.

Vasta, V., Nudda, A., Cannas, A., Lanza, M., and Priolo, A. (2008). Alternative feed resources and their effects on the quality of meat and milk from small ruminants. Animal Feed Science and Technology 147, 223-246.

Weakley, D. C., Stern, M. D., and Satter, L. D. (1983). Factors affecting disappearance of feedstuffs from bags suspended in the rumen. Journal of Animal Science 56, 493507.

Weatherburn, M. W. (1967). Phenol-hypochlorite reaction for determination of ammonia. Analytical Chemistry 39, 971-974.

Weiss, W. P., Frobose, D. L., and Koch, M. E. (1997). Wet tomato pomace ensiled with corn plants for dairy cows. Journal of Dairy Science 80, 2896-2900.

World Processing Tomato Council (WPTC). (2019). World Production Estimate as of 12 February 2019. [consulted 21/03/2019]. Available in: https://www.wptc.to/pdf/releases/WPTC\%20world\%20production\%20estimate\%20as 20of\%2012\% 20February\%202019.pdf (accessed on 21 March 2019).

Yemm, E. W., and Willis, A. J. (1954). The estimation of carbohydrates in plant extracts by anthrone. Biochemical 157, 508-514.

Yuangklang, C., Vasupen, K., Wongsuthavas, S., Bureenok, S., Panyakaew, P., Alhaidary, A., Mohamed, H. E., and Beynen, A. C. (2010). Effect of Replacement of Soybean meal by Dried Tomato Pomace on Rumen Fermentation and Nitrogen Metabolism in Beef Cattle. American Journal of Agricultural and Biological Sciences 5, 256-260. 


\section{Chapter VI. THE ACID \\ DETERGENT INSOLUBLE \\ NITROGEN (ADIN) ANALYSIS \\ OVERESTIMATES THE AMOUNT \\ OF N ASSOCIATED TO ACID \\ DETERGENT FIBRE}

Marcos, C. N., Carro, M. D., García, S., and González, J. (2018). The acid detergent insoluble nitrogen (ADIN) analysis overestimates the amount of $\mathrm{N}$ associated to acid detergent fibre. Animal Feed Science and Technology 244, 36-41. doi: 10.1016/j.anifeedsci.2018.08.002

ISI Journal Citation Reports Ranking 2018: Animal Feed Science and Technology was ranked 5 out of 61 Journals in the area of "Agriculture, Dairy \& Animal Science" 
$\sim 126 \sim$ 
Abstract: The acid detergent insoluble nitrogen (ADIN) fraction of feeds is usually assumed to be in- digestible, and some feeding systems for ruminants use the ADIN analysis as a measure of nitrogen $(\mathrm{N})$ availability. In a preliminary study conducted with 3 different feeds, we observed lower ${ }^{15} \mathrm{~N}$ abundance in ADIN compared with that in both total $\mathrm{N}$ and neutral detergent insoluble $\mathrm{N}$ (NDIN). Based on these results, we hypothesized that ADIN analysis overestimates the amount of $\mathrm{N}$ associated to acid detergent fibre (ADFom) due to N-contamination from cetyltrimethylammonium bromide (CTAB), a reagent used in the ADFom analysis. The objective of this work was to verify lower ${ }^{15} \mathrm{~N}$ abundances of ADIN than of total $\mathrm{N}$ and NDIN in different feeds, and to assess the magnitude of ADIN contamination. Samples from one corn crop (aerial biomass, grain and root) and two sunflower crops (SF; aerial biomass and seeds) were analysed for ${ }^{15} \mathrm{~N}$ abundance and content of total N, NDIN and ADIN. Samples had been ${ }^{15} \mathrm{~N}$-labelled by fertilizing with either ${ }^{15} \mathrm{NH}_{4} \mathrm{NO}_{3}$ or $\mathrm{NH}_{4}{ }^{15} \mathrm{NO}_{3}$, and there were three replicates per type of sample. The ${ }^{15} \mathrm{~N}$-abundance of total $\mathrm{N}$ and NDIN was similar $(\mathrm{P}>0.05)$ for all samples, whereas that of ADIN was lower $(\mathrm{P}<0.001$ to 0.037$)$ than values for total $\mathrm{N}$ and NDIN for all samples, excepting for SF seeds from one crop. Estimates of N-contamination of ADIN from CTAB were not affected by the fertilizer used to label N ( $P \geq 0.207)$, and values $(\mathrm{g} / \mathrm{g})$ ranged from 0.129 for corn grains to 0.447 for corn aerial biomass. N-contamination of ADIN was positively correlated with neutral detergent fibre (aNDFom), ADFom, hemicelluloses and cellulose content ( $\mathrm{P}<0.001 ; \mathrm{r}=0.770$ to $0.905 ; n=18$ and 22 for corn and SF, respectively), and negatively ( $\mathrm{P}<0.001$ to 0.048 ) with ADIN content (expressed as proportion of ADFom). The negative correlations $(\mathrm{P}<0.001)$ between N-contamination of ADIN and lignin (Lignin (sa))/ADFom ratio observed for all samples would indicate that Ncontamination of ADIN was reduced by cell wall lignification. In conclusion, the results showed that the use of CTAB in the ADFom analysis resulted in increased ADIN values, and therefore overestimated the amount of $\mathrm{N}$ associated to ADFom, questioning the use of ADIN as a parameter indicative of $\mathrm{N}$ availability. The possibility of replacing CTAB by a $\mathrm{N}$-free reagent in the ADFom analysis should be explored.

Keywords: Acid detergent insoluble nitrogen; ADFom; neutral detergent insoluble nitrogen; ${ }^{15} \mathrm{~N}$; $\mathrm{N}$ contamination; overestimation 


\section{VI.1. Introduction}

The acid detergent insoluble nitrogen (ADIN) analysis is widely accepted as a good measure of heat damage in forages (NRC, 2001; Goering et al., 1972), but poor relationships between ADIN and nitrogen $(\mathrm{N})$ indigestibility have been reported for non-forage plant protein sources that have been heat treated (Nakamura et al., 1994; Weiss et al., 1989). Despite this, some feeding systems for ruminants use the ADIN analysis as a measure of $\mathrm{N}$ availability. For example, in the Cornell Net Carbohydrate Protein System (Sniffen et al., 1992) the fraction C of crude protein (CP) is determined chemically as the ADIN and is considered to be undegradable. In the UK Metabolizable Protein System (Webster, 1987), the ADIN fraction is assumed to be both undegradable in the rumen and indigestible in the small intestine, and therefore the amount of digestible rumen undegraded protein in a feed is predicted from its ADIN content. However, several studies have demonstrated partial ADIN degradation in the rumen (Machacek and Kononoff, 2009; McNiven et al., 2002; Nakamura et al., 1994). Recent studies by our group (Vanegas et al., 2016; Guevara-González et al., 2015; Arroyo and González, 2013) showed a rapid initial degradation of ADIN, which was markedly greater than that observed for neutral detergent insoluble $\mathrm{N}$ (NDIN). Using ${ }^{15} \mathrm{~N}$-enriched feeds to analyze cell wall protein degradation, Vanegas et al. (2016) observed lower ${ }^{15} \mathrm{~N}$ abundance in ADIN than in total N and NDIN of three feeds, but the low number of samples available in their study precluded further investigations to explain these results. We hypothesized that the lower ${ }^{15} \mathrm{~N}$ abundance of ADIN might be due to contamination from cetyltrimethylammonium bromide (CTAB), a N-containing reagent used in the ADFom analysis. To test our hypothesis, ${ }^{15} \mathrm{~N}$-enriched samples of different plants were obtained from a previous agricultural study. The objective of this work was to verify the lower ${ }^{15} \mathrm{~N}$ abundance in ADIN compared with both total $\mathrm{N}$ and NDIN, and to assess the possible ADIN contamination and the factors influencing it.

\section{VI.2. Materials and methods}

VI.2.1. Samples and experimental procedures

The ${ }^{15} \mathrm{~N}$-enriched samples used in this study were obtained in previous agricultural experiments aimed at measuring the effects of nitrification inhibitors on 
$\mathrm{N} 2 \mathrm{O}$ losses in different crops (Guardia et al., 2018). Briefly, corn (Zea mays L. FAO class 600) samples were obtained in 2015 from 6 microplots $(1 \times 1 \mathrm{~m} ; 3$ microplots / treatment) which received either ${ }^{15} \mathrm{NH}_{4} \mathrm{NO}_{3}\left({ }^{15} \mathrm{NAM}\right)$ or $\mathrm{NH}_{4}{ }^{15} \mathrm{NO}_{3}\left({ }^{15} \mathrm{NIT}\right)$; both 98 atom $\%{ }^{15} \mathrm{~N}$; Campro Scientific GmbH, Berlin, Germany) to be labelled. Both ${ }^{15} \mathrm{NAM}$ and ${ }^{15}$ NIT were applied as a top-dressing at a rate of $90 \mathrm{~kg}$ total N / ha. At harvest, plants were cut by hand at the soil level, and then the aerial biomass (stem, leaves and cob) was separated from grain. In addition, roots situated in the middle of each microplot were sampled and washed with water to separate roots from soil. In total there were 18 corn samples (6 microplots $\left(3{ }^{15} \mathrm{NAM}\right.$ and $\left.3{ }^{15} \mathrm{NIT}\right) \times 3$ plant fractions). Sunflower (Helianthus annuus L., P64LL62 hybrid Pioneer) samples were obtained in 2016 using two different schemas of ${ }^{15} \mathrm{~N}$ fertilization: either the residual ${ }^{15} \mathrm{~N}$ from the previous corn crops (SF1) or by applying either ${ }^{15} \mathrm{NAM}$ or ${ }^{15} \mathrm{NIT}$ (both 10 atom $\%{ }^{15} \mathrm{~N}$; Campro Scientific GmbH, Berlin, Germany) as a top-dressing at a rate of $68 \mathrm{~kg}$ total $\mathrm{N} /$ ha to parcels which had not been previously ${ }^{15} \mathrm{~N}$-fertilized (SF2). Sunflower plants were cut as previously described and seeds were separated from the aerial biomass $\left(\right.$ stem + leaves + flower capitula or head). Unfortunately, one replicate for ${ }^{15} \mathrm{NAM}-\mathrm{SF} 2$ treatment was lost, and therefore a total of $22 \mathrm{SF}$ samples were available.

All samples were ground to pass a $1 \mathrm{~mm}$ screen before chemical analyses. Dry matter (ID 934.01), ash (ID 048.13) and ether extract (ID 920.39; analysed only in SF seed samples) contents were determined according to the AOAC International (2005) methods. Total N content was measured using a Leco FP258 Nitrogen Analyzer (Leco Corporation, St. Joseph, MI, USA). Analyses of neutral detergent fibre (aNDFom) (Van Soest et al., 1991), acid detergent fibre (ADFom; sequential analysis) and acid soluble lignin (lignin (sa)) (Robertson and Van Soest, 1981) were carried out sequentially using an ANKOM220 Fibre Analyzer unit (ANKOM Technology Corporation, Fairport, NY, USA). The aNDFom analyses were performed with alpha-amylase and without sodium sulphite, and aNDFom, ADFom and lignin (sa) values were expressed exclusive of residual ash. In addition, non-sequential ADFom analyses were performed in all samples of aerial biomass from ${ }^{15}$ NIT treatment in order to compare N-contamination in both ADFom procedures (sequential and direct). Hemicellulose, cellulose and pectin contents were estimated as aNDFom - ADFom, ADFom - lignin (sa), and nonsequential ADFom - sequential ADFom, respectively. Samples of SF seeds were 
defatted with diethyl ether employing an ANKOM XT10 extractor unit (ANKOM Technology Corporation, Fairport, NY, USA) before fibre analyses. Chemical composition of feed samples is given in Table 21.

Feed samples and residues in the ANKOM bags used in aNDFom and ADFom analysis were ground $(<100 \mu \mathrm{m})$ with a ball mill, and total $\mathrm{N}$ content was analysed as before described. Analysis of ${ }^{15} \mathrm{~N}$ abundance in feed samples, NDIN, ADIN and CTAB was performed by combustion using a Thermo 1112 Flash HT elemental analyzer hyphenated interfaced to a Thermo Delta V Advantage isotope ratio mass spectrometer (all Thermo Fisher Scientific, Bremen, Germany).

\section{VI.2.2 Calculations and statistical analyses}

The possible contamination of ADIN with $\mathrm{N}$ from the CTAB during the ADFom analysis was calculated by using Pearson's square method as: (averaged ${ }^{15} \mathrm{~N}$ abundance in total $\mathrm{N}$ and NDIN $-{ }^{15} \mathrm{~N}$ abundance in ADIN) / (averaged ${ }^{15} \mathrm{~N}$ abundance in total $\mathrm{N}$ and NDIN $-{ }^{15} \mathrm{~N}$ abundance in CTAB), in which all ${ }^{15} \mathrm{~N}$ abundances were expressed as atom $\%$. The average ${ }^{15} \mathrm{~N}$ abundance in total $\mathrm{N}$ and NDIN was used in the calculations because of the lack of differences between both values. The ${ }^{15} \mathrm{~N}$ abundance of CTAB was measured $(0.3660$ atom $\%)$ and used in the calculations.

${ }^{15} \mathrm{~N}$ abundance values were analysed independently for each feed sample as a mixed model by the PROC MIXED of SAS (SAS Inst. Inc., Cary, NC, USA). Effects of nitrogenous fraction, fertilizer and nitrogenous fraction $\mathrm{x}$ fertilizer interaction were included in the model as fixed effects, whereas microplot was considered as a random effect. The sums of squares were further partitioned by orthogonal contrasts to analyze differences among the three nitrogenous fractions. The contrasts were distributed as follows, C1: total N vs. NDIN, and C2: total N and NDIN vs. ADIN. Values of Ncontamination of ADIN estimated in samples labelled either with ${ }^{15}$ NAM or ${ }^{15}$ NIT were compared by a one-way ANOVA. The same analysis was used to compare the values of ${ }^{15} \mathrm{~N}$ abundance and $\mathrm{N}$-contamination of ADIN obtained by using either sequential or non-sequential ADFom analyses. Significance was declared at $\mathrm{P} \leq 0.05$, whereas $\mathrm{P}<$ 0.10 values were considered to be a trend. Relationships between $\mathrm{N}$ contamination in ADIN and chemical composition of feed samples were investigated by linear regression using the PROC CORR of SAS. 
Table 21. Chemical composition (g/kg DM unless otherwise stated) of corn and sunflower ${ }^{15} \mathrm{~N}$-enriched samples by using either ${ }^{15} \mathrm{NH}_{4} \mathrm{NO}_{3}\left({ }^{15} \mathrm{NAM}\right)$ or $\left.\mathrm{NH}_{4}{ }^{15} \mathrm{NO}_{3}{ }^{15} \mathrm{NIT}\right)$ as fertilizers $(n=3)$.

\begin{tabular}{|c|c|c|c|c|c|c|c|c|c|c|c|}
\hline \multirow{2}{*}{ Sample } & \multirow{2}{*}{ Fertilizer } & \multirow{2}{*}{$\begin{array}{l}\text { Organic } \\
\text { matter }\end{array}$} & \multirow{2}{*}{$\begin{array}{l}\text { Nitrogen } \\
\text { (N) }\end{array}$} & \multirow{2}{*}{$\begin{array}{l}\text { Ether } \\
\text { extract }^{2}\end{array}$} & \multirow{2}{*}{ aNDFom } & \multirow{2}{*}{ ADFom } & \multirow{2}{*}{$\begin{array}{l}\text { Lignin } \\
\text { (sa) }\end{array}$} & \multicolumn{2}{|c|}{$\begin{array}{c}\text { Neutral detergent insoluble } \mathrm{N} \\
\text { (NDIN) }\end{array}$} & \multicolumn{2}{|c|}{$\begin{array}{l}\text { Acid detergent insoluble } \mathrm{N} \\
\text { (ADIN) }\end{array}$} \\
\hline & & & & & & & & $\mathrm{g} / \mathrm{kg}$ aNDFom & $\mathrm{g} / \mathrm{kg} \mathrm{N}$ & $\mathrm{g} / \mathrm{kg}$ ADFom & $\mathrm{g} / \mathrm{kg} \mathrm{N}$ \\
\hline \multicolumn{12}{|l|}{ Corn } \\
\hline Aerial Biomass ${ }^{1}$ & ${ }^{15} \mathrm{NAM}$ & 943 & 7.4 & - & 750 & 383 & 25.6 & 3.6 & 364 & 2.3 & 11.6 \\
\hline Grain & ${ }^{15} \mathrm{NAM}$ & 986 & 16.4 & - & 136 & 15 & 4.9 & 23.1 & 192 & 9.2 & 8.6 \\
\hline Roots & ${ }^{15} \mathrm{NAM}$ & 822 & 7.6 & - & 726 & 428 & 67.9 & 5.8 & 547 & 5.6 & 316 \\
\hline Aerial Biomass ${ }^{1}$ & ${ }^{15} \mathrm{NIT}$ & 944 & 10.2 & - & 721 & 360 & 23.9 & 4.8 & 337 & 2.2 & 76.7 \\
\hline Grain & ${ }^{15} \mathrm{NIT}$ & 986 & 17.8 & - & 131 & 15 & 4.8 & 20.6 & 152 & 8.8 & 7.4 \\
\hline Roots & ${ }^{15} \mathrm{NIT}$ & 831 & 8.2 & - & 635 & 380 & 72.6 & 5.9 & 458 & 6.1 & 283 \\
\hline \multicolumn{12}{|l|}{ Sunflower 1} \\
\hline Aerial Biomass ${ }^{2}$ & ${ }^{15} \mathrm{NAM}$ & 842 & 16.0 & - & 476 & 289 & 55.4 & 8.1 & 241 & 4.4 & 80.2 \\
\hline Seeds & ${ }^{15} \mathrm{NAM}$ & 972 & 33.2 & 421 & 277 & 174 & 54.6 & 14.9 & 72.0 & 6.5 & 19.6 \\
\hline Aerial Biomass ${ }^{2}$ & ${ }^{15} \mathrm{NIT}$ & 863 & 15.9 & - & 478 & 294 & 58.4 & 7.5 & 227 & 4.4 & 80.9 \\
\hline Seeds & ${ }^{15} \mathrm{NIT}$ & 972 & 34.6 & 399 & 289 & 184 & 58.5 & 15.3 & 76.7 & 6.2 & 19.7 \\
\hline \multicolumn{12}{|l|}{ Sunflower 2} \\
\hline Aerial Biomass ${ }^{2}$ & ${ }^{15} \mathrm{NAM}$ & 866 & 12.9 & - & 446 & 275 & 53.4 & 8.2 & 284 & 4.4 & 94.7 \\
\hline Seeds & ${ }^{15} \mathrm{NAM}$ & 959 & 37.8 & 317 & 303 & 178 & 57.5 & 18.5 & 101 & 6.0 & 19.3 \\
\hline Aerial Biomass $^{2}$ & ${ }^{15} \mathrm{NIT}$ & 868 & 13.5 & - & 464 & 288 & 52.5 & 7.8 & 270 & 4.4 & 94.8 \\
\hline Seeds & ${ }^{15} \mathrm{NIT}$ & 963 & 40.1 & 337 & 293 & 173 & 61.0 & 16.6 & 80.3 & 6.0 & 17.1 \\
\hline
\end{tabular}

${ }^{1}$ Ether extract was determined only in sunflower seeds.

${ }^{2}$ Non sequential ADF values for ${ }^{15}$ NIT aerial biomass samples were 422, 367 and $360 \mathrm{~g} / \mathrm{Kg}$ DM for corn, SF1 and SF2, respectively 


\section{VI.3. Results}

Content of $\mathrm{N}$ and aNDFom in samples was variable and ranged from 7.4 to 40.1 and from 131 to $750 \mathrm{~g} / \mathrm{kg} \mathrm{DM}$, respectively (Table 21). There were also marked differences among samples in NDIN and ADIN content, which varied from 72 to 547 and from 7.4 to $316 \mathrm{~g} / \mathrm{kg} \mathrm{N}$, respectively.

As shown in Table 22, there were no differences $(\mathrm{P} \geq 0.31)$ in ${ }^{15} \mathrm{~N}$ abundance between total $\mathrm{N}$ and NDIN fractions for any group of samples, but ${ }^{15} \mathrm{~N}$ abundance of ADIN was lower $(\mathrm{P}<0.001$ to 0.02$)$ than the average value of total $\mathrm{N}$ and NDIN for all samples excepting $\mathrm{SF} 1$ seeds $(\mathrm{P}=0.17)$. Fertilization treatment $\mathrm{x} \mathrm{N}$ fraction interactions $(\mathrm{P}<0.001$ to 0.04$)$ were detected for all corn and SF2 samples. The ${ }^{15} \mathrm{~N}$ abundances in total N, NDIN and ADIN were greater $(\mathrm{P}<0.001)$ for ${ }^{15} \mathrm{NIT}$ compared with ${ }^{15} \mathrm{NAM}$ treatment for all corn and SF2 samples, whereas for SF1 samples differences did not reach the significance level $(\mathrm{P} \geq 0.14)$.

Estimates of $\mathrm{N}$-contamination were not affected ( $\mathrm{P}=0.21$ to 0.99 ; Table 23$)$ by the ${ }^{15} \mathrm{~N}$ abundance in feeds, which was determined by the compound used as fertilizer. Values of N-contamination of ADIN varied widely among samples, with aerial biomass samples having greater values $(>0.375 \mathrm{~g} / \mathrm{g})$ than both grain and seed samples $(<0.226$ $\mathrm{g} / \mathrm{g}$ ) for both corn and SF. 
Table 22. ${ }^{15} \mathrm{~N}$ abundance (atom\%) in total nitrogen (N), neutral detergent insoluble N (NDIN) and acid detergent insoluble N (ADIN) of corn and sunflower samples labelled with either ${ }^{15} \mathrm{NH}_{4} \mathrm{NO}_{3}\left({ }^{15} \mathrm{NAM}\right)$ or $\mathrm{NH}_{4}{ }^{15} \mathrm{NO}_{3}\left({ }^{15} \mathrm{NIT}\right)$ applied as fertilizers.

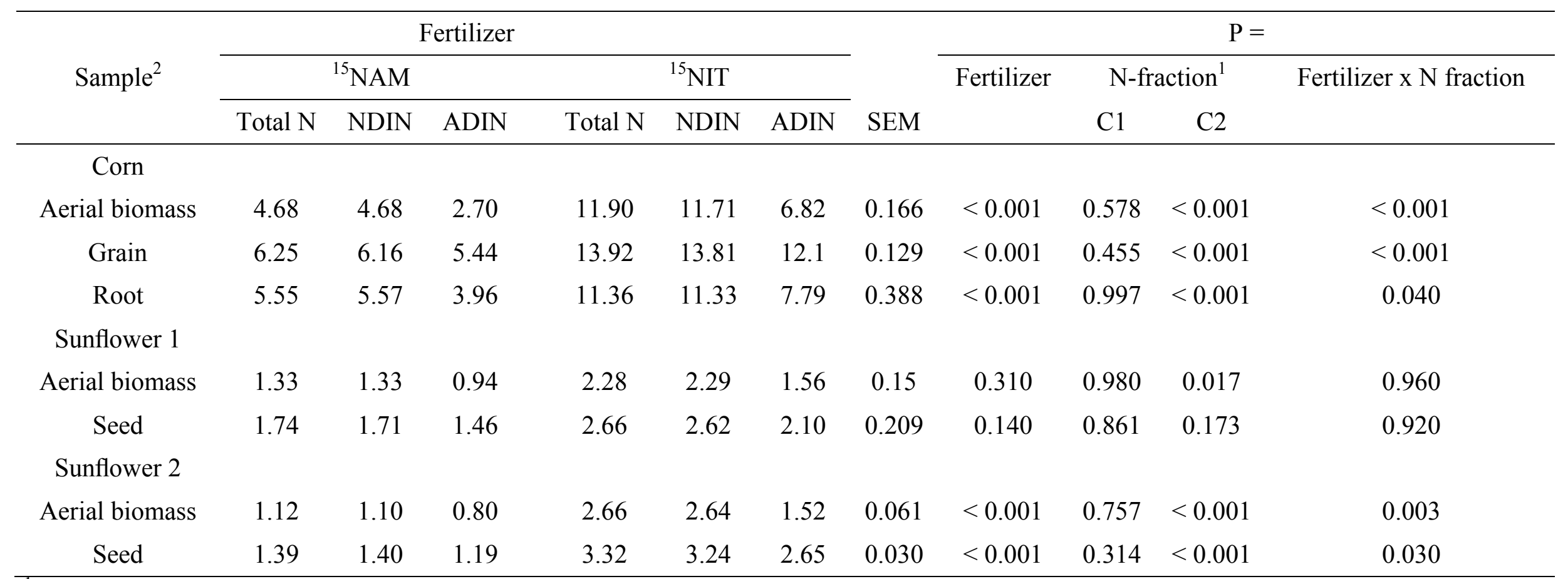

${ }^{1} \mathrm{C} 1$ : Total $\mathrm{N} v s$. NDIN; C2: Total N and NDIN vs. ADIN.

${ }^{2}$ A total of 18 samples of corn, 12 samples of sunflower 1 , and 10 samples of sunflower 2 
Table 23. N contamination of acid detergent insoluble nitrogen (ADIN; g/g) in corn and sunflower samples labelled with either ${ }^{15} \mathrm{NH}_{4} \mathrm{NO}_{3}\left({ }^{15} \mathrm{NAM}\right)$ or $\mathrm{NH}_{4}{ }^{15} \mathrm{NO}_{3}\left({ }^{15} \mathrm{NIT}\right)$ applied as fertilizers ${ }^{1}$.

\begin{tabular}{ccccc}
\hline Sample & \multicolumn{2}{c}{ Fertilizer } & \multirow{2}{*}{ SEM } & P $=$ \\
\cline { 2 - 3 } Corn & ${ }^{15} \mathrm{NAM}$ & ${ }^{15} \mathrm{NIT}$ & & \\
Aerial biomass & 0.456 & 0.437 & 0.0371 & 0.730 \\
Grain & 0.129 & 0.128 & 0.0426 & 0.990 \\
Root & 0.310 & 0.327 & 0.0451 & 0.800 \\
Sunflower 1 & & & & \\
Aerial biomass & 0.376 & 0.400 & 0.0673 & 0.820 \\
Seed & 0.202 & 0.225 & 0.0265 & 0.570 \\
Sunflower 2 & & & & \\
Aerial biomass & 0.414 & 0.493 & 0.0308 & 0.210 \\
Seed & 0.198 & 0.217 & 0.0093 & 0.300 \\
\hline
\end{tabular}

${ }^{1}$ Calculated by Pearson's square method as (average ${ }^{15} \mathrm{~N}$ abundance in total $\mathrm{N}$ and NDIN $-{ }^{15} \mathrm{~N}$ abundance in ADIN) / (average ${ }^{15} \mathrm{~N}$ abundance in total $\mathrm{N}$ and NDIN $-{ }^{15} \mathrm{~N}$ abundance in CTAB). All ${ }^{15} \mathrm{~N}$ abundances expressed as atom\%.

When chemical composition on DM basis were used (values in Table 21), Ncontamination of ADIN was positively correlated with aNDFom, ADFom, hemicelluloses and cellulose content $(\mathrm{P}<0.001 ; \mathrm{r}=0.77$ to $0.91 ; n=18$ and 22 for corn and SF, respectively) and negatively ( $\mathrm{P}<0.001$ to 0.05$)$ with content of NDIN and ADIN (expressed as proportion of aNDFom and ADFom, respectively), for both corn and SF samples with the exception of NDIN for SF samples $(\mathrm{P}=0.44)$. The Ncontamination of ADIN was also negatively correlated $(\mathrm{P}<0.001)$ with lignin (sa)/ADFom ratio for all samples, and with lignin (sa) content and lignin (sa)/aNDFom ratio for SF samples $(\mathrm{P}<0.001$ to 0.03$)$. When fibre fractions of SF-seeds were expressed on defatted seed DM basis, no correlation was observed between $\mathrm{N}$ contamination of ADIN and aNDFom, ADFom and hemicelluloses content (Table 24), but the negative correlation between N-contamination of ADIN and lignin (sa) content was stronger than that detected when chemical composition was expressed on DM basis ( $\mathrm{P}=0.03$ and $<0.001$, respectively).

As shown in Table 25, lower ADIN values were obtained by sequential ADFom 
analysis compared with the non-sequential procedure for all tested samples $(\mathrm{P} \leq 0.02)$. However, the influence of the method of ADFom analysis on ${ }^{15} \mathrm{~N}$ abundance and $\mathrm{N}$ contamination of ADIN varied among samples. For corn samples, the non-sequential ADFom analysis resulted in $43.3 \%$ lower ${ }^{15} \mathrm{~N}$ abundance of ADIN than the sequential method, but differences did not reach the significance level $(\mathrm{P}=0.09)$. N-contamination tended to be greater $(\mathrm{P}=0.08)$ for the non-sequential compared with the sequential ADFom analysis, but there were no differences between methods $(P=0.65)$ in the amount of true ADIN estimated as ADIN corrected for N-contamination from CTAB. In contrast, for SF samples no differences were detected either in ${ }^{15} \mathrm{~N}$ abundance or in $\mathrm{N}$ contamination of ADIN, excepting a trend $(\mathrm{P}=0.09)$ to greater $\mathrm{N}$-contamination in nonsequential compared with sequential ADFom procedure for SF1 sample. However, the amount of true ADIN was greater $(\mathrm{P} \leq 0.01)$ for the non-sequential compared with the sequential ADFom analysis for both SF1 and SF2 samples. 
Table 24. Correlation matrix (values of Pearson coefficient and P values in brackets) of nitrogen (N) contamination of acid detergent insoluble N (ADIN) with fibre fractions in corn and sunflower samples ${ }^{1}$.

\begin{tabular}{|c|c|c|c|c|c|c|c|c|c|}
\hline Sample & aNDFom & ADFom & $\begin{array}{l}\text { Lignin } \\
(\mathrm{sa})\end{array}$ & Hemicelluloses & Cellulose & $\begin{array}{l}\text { Acid detergent insoluble } \mathrm{N} \\
\text { (NDIN) }\end{array}$ & ADIN & $\begin{array}{l}\text { Lignin } \\
\text { (sa)/aNDFom }\end{array}$ & $\begin{array}{l}\text { Lignin } \\
\text { (sa)/ADFom }\end{array}$ \\
\hline $\begin{array}{c}\text { Corn } \\
(n=18)\end{array}$ & $\begin{array}{c}0.864 \\
(<0.001)\end{array}$ & $\begin{array}{c}0.807 \\
(<0.001)\end{array}$ & $\begin{array}{c}0.253 \\
(0.310)\end{array}$ & $\begin{array}{c}0.905 \\
(<0.001)\end{array}$ & $\begin{array}{c}0.875 \\
(<0.001)\end{array}$ & $\begin{array}{c}-0.873 \\
(<0.001)\end{array}$ & $\begin{array}{c}-0.903 \\
(<0.001)\end{array}$ & $\begin{array}{l}-0.192 \\
(0.450)\end{array}$ & $\begin{array}{c}-0.925 \\
(<0.001)\end{array}$ \\
\hline \multicolumn{10}{|l|}{$\begin{array}{l}\text { Sunflower } \\
(n=22)^{2}\end{array}$} \\
\hline A & $\begin{array}{c}0.829 \\
(<0.001)\end{array}$ & $\begin{array}{c}0.843 \\
(<0.001)\end{array}$ & $\begin{array}{l}-0.467 \\
(0.030)\end{array}$ & $\begin{array}{c}0.770 \\
(<0.001)\end{array}$ & $\begin{array}{c}0.867 \\
(<0.001)\end{array}$ & $\begin{array}{l}-0.172 \\
(0.440)\end{array}$ & $\begin{array}{l}-0.426 \\
(0.050)\end{array}$ & $\begin{array}{c}-0.856 \\
(<0.001)\end{array}$ & $\begin{array}{c}-0.864 \\
(<0.001)\end{array}$ \\
\hline B & $\begin{array}{c}0.138 \\
(0.540)\end{array}$ & $\begin{array}{c}0.140 \\
(0.530)\end{array}$ & $\begin{array}{c}-0.798 \\
(<0.001)\end{array}$ & $\begin{array}{c}0.035 \\
(0.880)\end{array}$ & $\begin{array}{c}0.686 \\
(<0.001)\end{array}$ & $\begin{array}{l}-0.172 \\
(0.440)\end{array}$ & $\begin{array}{l}-0.426 \\
(0.050)\end{array}$ & $\begin{array}{l}-0.870 \\
(<0.001)\end{array}$ & $\begin{array}{c}-0.888 \\
(<0.001)\end{array}$ \\
\hline
\end{tabular}

${ }^{1}$ Data expressed as g/kg DM, excepting NDIN and ADIN that are expressed as g/kg of NDF and ADF, respectively.

${ }^{2}$ A: using chemical composition data shown in Table 21; B: using chemical composition data of defatted seeds. 
Table 25. Values of acid detergent insoluble N (ADIN) content, ${ }^{15} \mathrm{~N}$-abundance and N-contamination of ADIN, and ADIN corrected for N-contamination from cetyltrimethylammonium bromide (true ADIN) in samples from aerial biomass of corn and sunflower (SF1 and SF2) obtained by using sequential and nonsequential methods of ADFom analysis.

\begin{tabular}{|c|c|c|c|c|c|c|c|c|c|c|c|c|}
\hline \multirow[b]{2}{*}{ Item } & \multicolumn{4}{|c|}{ Corn $(n=3)$} & \multicolumn{4}{|c|}{ Sunflower $1(n=3)$} & \multicolumn{4}{|c|}{ Sunflower $2(n=3)$} \\
\hline & $\begin{array}{l}\text { Sequential } \\
\text { ADFom }\end{array}$ & $\begin{array}{l}\text { Non- } \\
\text { sequential } \\
\text { ADFom }\end{array}$ & SEM & $\mathrm{P}=$ & $\begin{array}{l}\text { Sequential } \\
\text { ADFom }\end{array}$ & $\begin{array}{l}\text { Non- } \\
\text { sequential } \\
\text { ADFom }\end{array}$ & SEM & $\mathrm{P}=$ & $\begin{array}{l}\text { Sequential } \\
\text { ADFom }\end{array}$ & $\begin{array}{l}\text { Non- } \\
\text { sequential } \\
\text { ADFom }\end{array}$ & SEM & $\mathrm{P}=$ \\
\hline ADIN, g/kg ADF & 2.17 & 3.33 & 0.096 & 0.010 & 4.37 & 6.83 & 0.111 & 0.004 & 4.27 & 6.81 & 0.227 & 0.020 \\
\hline $\begin{array}{c}\text { ADIN, } \\
\text { atom } \% 15 \mathrm{~N}- \\
\text { abundance of }\end{array}$ & 6.82 & 3.87 & 0.658 & 0.090 & 1.53 & 1.38 & 0.038 & 0.110 & 1.56 & 1.53 & 0.283 & 0.290 \\
\hline $\begin{array}{c}\text { N-contamination of } \\
\text { ADIN, g/g }\end{array}$ & 0.437 & 0.685 & 0.0555 & 0.080 & 0.400 & 0.471 & 0.0167 & 0.090 & 0.493 & 0.491 & 0.0126 & 0.530 \\
\hline $\begin{array}{c}\text { True ADIN, g/kg } \\
\text { ADF }\end{array}$ & 1.22 & 1.09 & 0.183 & 0.650 & 2.66 & 3.63 & 0.074 & 0.010 & 2.22 & 3.48 & 0.100 & 0.010 \\
\hline
\end{tabular}




\section{VI.4. Discussion}

Samples with variable chemical composition and a wide range of ${ }^{15} \mathrm{~N}$ abundance were used to test the hypothesis that ADIN might be contaminated with $\mathrm{N}$ from $\mathrm{CTAB}$ during the ADFom analysis. Chemical composition of samples was in the range reported in the literature (NRC, 2001). The lower ${ }^{15} \mathrm{~N}$ abundance in ${ }^{15} \mathrm{NAM}$ samples was mainly attributed to the fact that ammonia-N is not as readily utilized by the plants as nitrate-N and it can be partially lost to the atmosphere.

The lack of differences in ${ }^{15} \mathrm{~N}$ abundance between total $\mathrm{N}$ and NDIN fractions agrees with the results of Rodríguez and González (2006), who observed either similar values or only subtle differences $(<0.9 \%)$ between the natural ${ }^{15} \mathrm{~N}$ abundance of the whole feed and that of the insoluble fraction (obtained by washing 3 times for $5 \mathrm{~min}$ in a turbine washing machine) in 14 feeds commonly used in ruminant feeding. These results would indicate a homogeneous distribution of ${ }^{15} \mathrm{~N}$ atoms within each plant tissue. The decrease in ${ }^{15} \mathrm{~N}$ abundance of ADIN compared with the average ${ }^{15} \mathrm{~N}$ abundance of total $\mathrm{N}$ and NDIN ranged from $12.7 \%$ for corn grain to $42.6 \%$ for SF2 aerial biomass (both labelled with ${ }^{15} \mathrm{NIT}$ ). Lower ${ }^{15} \mathrm{~N}$ abundances of ADIN than of total $\mathrm{N}$ and NDIN have also been reported by Vanegas et al. (2016) in 3 single samples (sunflower seed, wheat grain and wheat straw). These results might indicate a $\mathrm{N}$ - contamination with $\mathrm{N}$ from CTAB (0.3660 atom $\%{ }^{15} \mathrm{~N}$ abundance) during the ADFom analysis, as CTAB is the only N-containing chemical used during the ADFom procedure. N-contamination values for SF1 and SF2 seeds were similar $(\mathrm{P}=0.86$; averaged values 0.213 and 0.208 $\mathrm{g} / \mathrm{g}$, respectively), and they are in agreement with the 0.192 value calculated from the results by Vanegas et al. (2016) for another single sample of SF seeds.

The observed relationships between ADIN contamination and chemical composition of samples showed that N-contamination of ADIN increased with increasing structural carbohydrate content of feeds, but was reduced by ADFom lignification. The negative correlation between N-contamination of ADIN and ADIN content is justified by the fact that $\mathrm{N}$-contamination was expressed as proportion of ADIN, and therefore N-contamination was greater for feeds with lower $\mathrm{N}$ content. The fact that no significant correlation was observed between N-contamination of ADIN and aNDFom, ADFom and hemicelluloses content of SF samples when fibre fractions of SF seeds were expressed on defatted seed DM basis can be explained by the similar content 
of SF aerial biomass and seeds samples in aNDFom (477 vs. 482 g / kg DM for SF1, and 457 vs. 442 g / kg DM for SF2, respectively), ADFom (292 vs. 307 g / kg DM, and 283 vs. 260 g / kg DM) and hemicelluloses (185 vs. 176 g / kg DM, and 174 vs. 182 g / $\mathrm{kg}$ DM) when seeds data were expressed on defatted basis. The stronger correlation between N-contamination of ADIN and lignin (sa) content observed when chemical com- position was expressed on defatted DM basis compared with that when expressed on DM basis ( $\mathrm{P}=<0.001$ and 0.03 , respectively) reinforces the idea of the negative influence of lignin (sa) content on N-contamination of ADIN.

The N-contamination of ADIN during the ADFom analysis can help to explain previous results reporting high digestibility values of ADIN in non-forage protein feeds (Machacek and Kononoff, 2009; McNiven et al., 2002; Weiss et al., 1989). Previous studies by our group (Vanegas et al., 2016; Arroyo and González, 2013) also showed a rapid initial rate of ADIN degradation and high ruminal degradability values (close to those observed for NDIN) for high-fibre low-protein forages (poor-quality Italian ryegrass hay and wheat straw, respectively). The ADIN overestimation observed in the present study is consistent with these results, because it seems probable that $\mathrm{N}$ contamination of ADIN will be greater in feeds than in faeces or incubation residues analysed to determine digestibility or ruminal degradability of ADIN, which usually have greater lignin content than feeds.

In agreement with our results on aerial biomass samples, others have reported lower ADIN values by sequential ADFom analysis compared with the non-sequential one (Arroyo and González, 2013; Cassida et al., 2007; Demarquilly et al., 1989). Differences between both procedures have been mainly attributed to the removal by the treatment with neutral detergent of feed components (mainly pectins) that are not removed by the treatment with acid detergent solution. However, the influence on ${ }^{15} \mathrm{~N}$ abundance and N-contamination of ADIN varied among samples (Table 25), which might be related to their pectin content and characteristics. Despite the low number of corn aerial biomass samples, a positive correlation $(\mathrm{P}=0.005 ; \mathrm{r}=0.999 ; n=3)$ was observed between the increase in $\mathrm{N}$-contamination in the non-sequential ADFom analysis compared with the sequential procedure and the content in pectins, resulting in a N-contamination increase of 1.04 percentage points per $\mathrm{g}$ of pectin. This might indicate an additional retention of $\mathrm{N}$ from $\mathrm{CTAB}$ in the pectins in the non-sequential analysis, but further analysis with a large number of samples are required to confirm this 
hypothesis.

The overestimation of ADIN content by N-contamination from CTAB might have also other implications, as it would cause an underestimation of the microbial contamination in the ADFom incubation residues obtained in the in situ method when this method was performed combined with ${ }^{15} \mathrm{~N}$ infusion as in some previous studies (Guevara-González et al., 2015; Arroyo and González, 2013). Finally, it is worth to notice that $\mathrm{N}$ associated to fibre fractions obtained by other methods of fibre analysis might be contaminated if $\mathrm{N}$-containing reagents are used in these procedures, but the analysis of ${ }^{15} \mathrm{~N}$ abundance in ${ }^{15} \mathrm{~N}$-enriched samples would be a suitable method to test

this hypothesis. Determining ${ }^{15} \mathrm{~N}$ abundance allows estimating $\mathrm{N}$-contamination, but does not inform about the whole compound absorbed from CTAB by the ADFom. The potential importance of ADFom overestimations supports the need of additional studies on contamination from $\mathrm{CTAB}$ and of replacing the CTAB by a $\mathrm{N}$-free reagent in the ADFom analysis.

\section{VI.5. Conclusions}

The results of this study showed that the use of CTAB in the ADFom analysis overestimated the amount of $\mathrm{N}$ associated to ADFom. The magnitude of the $\mathrm{N}$ contamination varied with the feed tested, as it was greater for feeds with high structural carbohydrates content and was reduced with high ADFom lignification. Compared with the sequential ADFom analysis, non-sequential ADFom analysis resulted in increased ADIN content for all tested samples. The amount of ADIN corrected for $\mathrm{N}$ contamination from CTAB was greater for the non-sequential analysis compared with the sequential analysis for sunflower samples, but no differences were detected for corn samples. The overestimation of ADIN showed in this study for both ADFom procedures questions the use of ADIN as a parameter indicative of $\mathrm{N}$ availability of feeds. The possibility of replacing CTAB by a $\mathrm{N}$-free reagent in the ADFom analysis should be explored.

Conflict of interest: The authors declare that they have no conflict of interest.

Acknowledgements and Funding: Funding from the Spanish Ministry of Economy and Competitiveness (Projects AGL2012-31064 and AGL2016-75322-C2-1-R) is gratefully acknowledged. Analyses of ${ }^{15} \mathrm{~N}$ isotope ratios were performed at the Servicio 
Interdepartamental de Investigación of the Autonomous University of Madrid (Spain).

References

Association of Official Analytical Chemists (AOAC). (2005). Official Methods of Analysis, 18th ed. AOAC International.

Arroyo, J. M., and González, J. (2013). Effects of microbial colonization in the rumen on concentration and degradability estimates of fibre fractions. Livestock Science 153, 101-107.

Cassida, K. A., Turner, K. E., Foster, J. G., and Hesterman, O. B. (2007). Comparison of detergent fiber analysis methods for forages high in pectin. Animal Feed Science and Technology 135, 283-295.

Demarquilly, C., Andrieu, J., Michalet-Doreau, B., and Sauvant, D. Measurement of the nutritive value of feeds. London and Paris, ed. Jarriage, R. 1989. In "Ruminant Nutrition. Recommended Allowance and Feed Tables". pp. 193-208. INRA and John Libbey and Co Ltd.

Goering, H. K., Gordon, C. H., Hemken, R. W., Waldo, D. R., Van Soest, P. J., and Smith, L. W. (1972). Analytical estimates of nitrogen digestibility in heat damaged forages. Journal of Dairy Science 55, 1275-1280.

Guardia, G., Vallejo, A., Cardenas, L. M., Dixon, E. R., and García-Marco, S. (2018). Fate of $15 \mathrm{~N}$-labelled ammonium nitrate with or without the new nitrification inhibitor DMPSA in an irrigated maize crop. Soil Biology and Biochemistry 116, 193-202.

Guevara-González, J., Mouhbi, R., Arroyo, J. M., Alvir, M. R., and González, J. (2015). Effects of correcting for microbial contamination and the use of sodium sulphite in NDF analyses on the ruminal fibre degradability of several feeds. The Journal of Agricultural Science Cambridge 153, 361-370.

Machacek, K. J., and Kononoff, P. J. (2009). The relationship between acid detergent insoluble nitrogen and nitrogen digestibility in lactating dairy cattle. The Professional Animal Scientist 25, 701-708.

McNiven, M. A., Prestløkken, E., Mydland, L. T., and Mitchell, A. W. (2002). Laboratory procedure to determine protein digestibility of heat-treated feedstuffs for dairy cattle. Animal Feed Science and Technology 96, 1-13.

Nakamura, T., Klopfenstein, T. J., and Britton, R. A. (1994). Evaluation of acid 
detergent insoluble nitrogen as an indicator of protein quality in nonforage proteins. Journal of Animal Science 72, 1043-1048.

NRC. (2001). Nutrient Requirements of Dairy Cattle, 7th ed. National Academy of Sciences.

Robertson, J. B., and Van Soest, P. J. The detergent system of analysis and its application to human foods. New York, USA, ed. James, W. P. T., Theander, O. 1981. In "The Analysis of Dietary Fiber in Food". pp. 123-142. Marcel Dekker.

Rodríguez, C. A., and González, J. (2006). In situ study of the relevance of bacterial adherence to feed particles on the contamination and accuracy of rumen degradability estimates of feeds of vegetable origin. British Journal of Nutrition 96, 316-325.

Sniffen, C. J., O’Connor, J. D., Van Soest, P. J., Fox, D. G., and Russell, J. B. (1992). A net carbohydrate and protein system for evaluating cattle diets: II Carbohydrate and protein availability. Journal of Dairy Science 70, 3562-3577.

Van Soest, P. J., Robertson, J. B., and Lewis, B. A. (1991). Methods for dietary fiber, neutral detergent fiber and nonstarch polysaccharides in relation to animal nutrition. Journal of Dairy Science 74, 3583-3597.

Vanegas, J. L., Arroyo, J. M., and González, J. (2016). Ruminal degradation of cell wall associated nitrogenous compounds of several 15N-labeled feeds. Journal of the Science of Food and Agriculture 96, 3991-3997.

Webster, A. J. F. Metabolizable protein - the UK approach. Luxembourg, ed. Alderman, G., Jarrige, R. 1987. In "Feed Evaluation and Protein Requirement System for Ruminants”. pp. 47-57. Commission of European Communities.

Weiss, W. P., Erickson, D. O., Erickson, G. M., and Fisher, G. R. (1989). Barley distillers grains as a protein supplement for dairy cows. Journal of Dairy Science $\mathbf{7 2}$, 980. 


\section{Chapter VII. GENERAL DISCUSSION}


Spain is one of the largest producers of fruit and vegetables of the European Union (MAPA, 2019a). As a consequence, a large volume of agroindustrial by-products products are generated in our country. However, these by-products can be used in animal feeding, which is one of the most valuable options as it reduces the environmental impact related to the production of large quantities of such products. Utilization of agroindustrial by-products in animal feeding could also contribute to improve the sustainability of livestock systems (Pascual Vidal, 2015; del Prado et al., 2013). In addition, by-products also can contain bioactive compounds that might improve the quality of animal products (Romero-Huelva et al., 2012). Nevertheless, utilization of agroindustrial by-products in animal feeding requires proper knowledge on their nutritional value. Therefore, the objective of this Doctoral Thesis was to evaluate the nutritive value of two by-products that are produced in huge amounts in Spain: olive cake (OC) and tomato pomace (TP).

Spain leads the world production of olive oil. Currently, the most used olive oil extraction system in our country is the two-phase system which generates a by-product called "alperujo". This "alperujo" can be further processed and other by-products are generated: crude $\mathrm{OC}(\mathrm{COC})$, which is generated after drying and removing the olive stones, and exhausted OC (EOC), which is produced after performing a second oil extraction. However, other by-products are generated, such as cyclone OC (CYOC). The objective of the first and second Experiment (Paper 1 and 2) of this Doctoral Thesis was to determine the variability in the chemical composition and in vitro ruminal fermentation of $\mathrm{OC}$ by-products and to analyse the influence of storage time and further processing (COC, EOC and CYOC) on the nutritive value. Additionally, in the third Experiment (Paper 5), we studied the effect of the particle size on nutritive value of COC samples.

There were marked differences among OC types in their chemical composition. Most notable differences were ether extract (EE) and neutral detergent fibre (NDF) content. Average values for EE in COC, EOC and CYOC samples were 110, 15.9 and $157 \mathrm{~g} / \mathrm{kg}$ dry matter (DM), respectively and 570, 645 and $441 \mathrm{~g} / \mathrm{kg}$ DM for NDF. Chemical composition is highly dependent on the processes OC has gone through. For example, as a result of the second oil extraction, EE content decreased and proportionally other fractions, such as NDF, total soluble polyphenols (TSP) and total sugars increased On the other hand, there were no differences in nitrogen $(\mathrm{N})$ content 
among OC types but acid detergent insoluble N (ADIN) content in EOC samples was significantly greater, as a consequence of heat applied during the additional oil extraction. Nevertheless the negative effect of fat in ruminal fermentation reported in the literature (Maia et al., 2007), no negative effect was observed in our studies.

Total sugars content was the most correlated fraction with fermentative parameters, as can be seen in the models obtained in the Experiment 2 (Paper 2). However, NDF content played an important role as well. Exhausted OC had the greatest values for fermentative parameters (potential gas production (PGP): $78.1 \mathrm{ml} / \mathrm{g} \mathrm{DM}$; average gas production rate (AGPR): $3.01 \mathrm{ml} / \mathrm{h}$; DM effective degradability (DMED): $245 \mathrm{~g} / \mathrm{kg} \mathrm{DM}$ ) followed by CYOC and COC, which correlated with the total sugars content of the samples. Processing of alperujo did not modify the volatile fatty acids (VFA) profile in the in vitro incubations.

In the Experiment 5 (Paper 3), COC samples were compared with other fibrous feeds (results not shown) and overall, we observed that COC samples have lower nutritive value than alfalfa hay, but similar to barley straw. As for the effect of storage time, it was clear that storage time was related with the quality of OC in a way it could be used to determine its AGPR and the amount of fermentable organic matter (FOM). With increasing storage time, nutritive value of $\mathrm{OC}$ decreased as a result of the degradation of easily fermentable fractions, such as total sugars. Dry matter effective degradability decreased linearly $(\mathrm{P}<0.001)$ by 35.9 and $45.5 \%$ as storage time augmented from 1 to 6 months for COC and EOC, respectively This effect was more remarkable over the first months of storage, so it would be recommended to store the alperujo up to a maximum of 2 months to avoid nutritive loses. Olive cake can be used as a replacement of straw in low production ruminants (Molina-Alcaide and YáñezRuiz, 2008); however, short-stored OC has better nutritive quality than straw and provides other beneficial effects such as fat and polyphenols which can improve the quality of the end product; (meat or milk) (Luciano et al., 2013 and Abbeddou et al., 2011).

A decrease in total soluble polyphenols in OC over the storage period was observed, probably as a result of microbial degradation or enzymes. These changes have been reported by other authors (Alhamad et al., 2017; Alburquerque et al., 2006), and they must be taken in account if the objective of feeding $\mathrm{OC}$ is to provide the animal 
with the biocompounds present in the olive. Finally, we observed differences in the nutritive value of OC with different particle size. The OC samples differing in particle size showed differences in chemical composition and in vitro ruminal fermentation parameters, with samples having more than $3 \mathrm{~mm}$ or less than $1 \mathrm{~mm}$ showing the greatest fermentability. In samples smaller than $1 \mathrm{~mm}$, the high fermentability could be linked to the lower content of fibre, and in samples greater than $3 \mathrm{~mm}$, highly fermentable fractions amalgam to form bigger particles (Bacha, personal communication). The nutritive value of the analysed OC samples was low, which is in agreement with the literature (Molina-Alcaide and Yáñez-Ruiz, 2008), and the variations observed in the nutritive value was highly dependent on factors such as processing, storage time or particle size. In general, OC could replace straw in animal feeding with a lower cost for the farmer while providing an extra source of fat and biocompunds.

Tomato is one the most common crop worldwide, and the fruits are rich in lycopene, phenols, organic acids, vitamins and other components (Giovanelli and Paradiso, 2002). In the tomato industry, TP is generated as the result of processing tomatoes to produce juices, creams or sauces (Ventura et al., 2009). Tomato pomace is made up of peels, seed and small amounts of pulp. Most agroindustrial by-products are highly variable depending on external factors and TP is not an exception ( $\mathrm{Lu}$ et al., 2019). The objective of the Experiment 4 (Paper 3) was to determine the variability in nutritive value for ruminants of TP samples obtained at different times from two factories and to analyze its effect on in vitro fermentation when it was included in a high-concentrate diet.

Samples of TP were rich in N (average value $25.6 \mathrm{~g} / \mathrm{kg} \mathrm{DM})$ and EE $(82.7 \mathrm{~g} / \mathrm{kg}$ $\mathrm{DM}$ ). Tomato pomace is a fibrous byproduct rich in NDF and acid detergent fibre (ADF), and the fibre content observed in our TP samples (average values $572439 \mathrm{~g} / \mathrm{kg}$ $\mathrm{DM}$ for NDF and ADF, respectively) was greater than that measured for other byproducts in our laboratory, such as sugar beet pulp (487 and $224 \mathrm{~g} / \mathrm{kg}$ DM for NDF and ADF, respectively) and dried distillers grains with solubles (DDGS) (340 and 88.1 $\mathrm{g} / \mathrm{kg}$ DM for NDF and ADF, respectively). Although TP samples had a relatively high content of $\mathrm{N}$, a great part is bound to the $\mathrm{ADF}$ (ADIN), being this proportion greater than in other by-products (ADIN: 2.05 vs 0.11 and $0.09 \mathrm{~g} / \mathrm{kg} \mathrm{DM}$ for TP, sugar beet pulp and DDGS), and the ruminal degradability and intestinal digestibility of $\mathrm{N}$ was low 
$(510 \mathrm{~g} / \mathrm{kg}$ and $459 \mathrm{~g} / \mathrm{kg}$, respectively). The content of sugars in TP was also considerable (122 g/kg DM), compared with thevalues reported for sugar beet pulp $(48.0 \mathrm{~g} / \mathrm{kg} \mathrm{DM})$. The high content of easily fermented sugars is probably responsible for the low Lag and high AGRP values measured for TP samples $(2.45 \mathrm{~h}$ and $8.54 \mathrm{ml} / \mathrm{h}$, respectively). Nevertheless, the high lignification of fibre in TP reduces its nutritive value. Values of chemical composition and rumen degradability obtained for TP samples obtained in our study differ from those reported by other authors (Abbeddou et al., 2011; Fondevila et al., 1994), but differences in chemical composition of the original fruits, in cultivation conditions and processing can help to explain the high variability in TP. In our study, no differences were observed in either chemical composition or fermentative parameters among samples from the two processing factories, probably as a result of similar processing in both. However, there were significant differences in EE and lignin content among sampling times, but the composition of other fractions remained unchanged.

Several authors have studied the effect of including tomato by-products in diets for small ruminants on the productive response, as well as on the quality of the meat and milk (Valenti et al., 2018; Romano et al., 2010). Romero-Huelva et al., (2010) also studied the effect of including fresh tomato in dairy goats diets on methane production and reported a reduction of $39 \%$ in the methane emissions, but no information on the possible effects of TP on methane production is available. In the Experiment 4, we studied in vitro the effect of including TP up to $180 \mathrm{~g} / \mathrm{kg}$ DM in a diet for fattening lambs. We observed an increase in fermentative parameters, probably as a result of replacing straw for $\mathrm{TP}$, which has a higher nutritive value. On the other hand, we did not detectc any antimethanogenic effect as observed with fresh tomato fruits, which could be caused by the deterioration of the biocompounds responsible for the antimethanogenic properties during thermal processing of TP. Therefore, we concluded that TP can be included up to $180 \mathrm{~g} / \mathrm{kg}$ DM in vitro in diets for fattening lambs with no negative effects on ruminal fermentation, although these results should be confirmed in in vivo trials. Even though TP has a high content of N, it is not recommended to use it as a protein source because the low $\mathrm{N}$ availability. On the contrary, it could be used as a cheap fibrous feedstuff in farms near to the processing industries, as the high water content precludes its use in remote farms and the drying process or the transport would increase the price of TP substantially. 
The ADIN fraction has been used to estimate the $\mathrm{N}$ digestibility in forages as well as to determine heat damage. However, in heat treated non-forage feeds, poor relationships have been reported. Despite this, some feeding systems, such as the UK Metabolizable Protein System and the Cornell Net Carbohydrate and Protein System, utilize the ADIN analysis as a measure of $\mathrm{N}$ availability. Both systems assume that the ADIN fraction is indigestible, although it has been reported a certain degree of ADIN digestibility. As many by-products contain a substantial proportion of ADIN in Experiment 6 (Paper 4), we proved that ADIN content is overestimated due to the contamination of samples with cetyltrimethylammonium bromide (CTAB) during the ADF analysis previous to ADIN determination. We indicated, as well, that the most reactive fraction and the most susceptible fraction to to such contamination are the pectins, and that the observed relationships between ADIN contamination and chemical composition of samples indicate that N-contamination of ADIN increased with increasing structural carbohydrate content of feeds, but it was reduced by ADF lignification. Forages usually have low content of pectins and are highly lignificated, whereas non-forage feeds might have greater pectins contents and lower lignification degree. This could be one of the reasons explaining whay ADIN analyses have been successfully used in forages to determine $\mathrm{N}$ digestibility. The contamination of $\mathrm{N}$ due to CTAB might be the responsible for the ADIN digestibility reported in the literature. As we stated earlier, the agroindustrial by-products studied in this Thesis are fibrous and can contain high amounts of ADIN. In this context, analysing ADIN in agroindustrial byproducts could provide useful information about protein degradability and digestibility, and be useful to determine the heat damage of these by-products, as usually they undergo processes where heat is required, such as drying.

Agroindustrial by-products contain bioactive compounds that might improve the quality of animal products (Romero-Huelva et al., 2012). In the previous experiments we studied in vitro the nutritive value of two agroindustrial by-products, OC and TP. The next step would be including such by-products in diets to assess their effect on animal performance and and products quality. The objective of the Experiment 5 (Paper 6) was to analyze the effect of including agroindustrial by-products, such as DDGS, dried citrus pulp (DCP) and EOC in a diet for dairy goats on nutrient digestibility, ruminal fermentation, methane production, urinary excretion of purine derivatives (PD) and milk yield and composition. The DDGS replaced soybean meal as a protein source, 
whereas the DCP replaced cereals as an energy source and the EOC was included as an extra source of fat. In this Experiment, the objective was not to determine the effect of each single by-product on the parameters studied, but to study the viability of feeding a diet containing a high proportion of agroindustrial by-products, as it could alleviate the environmental impact of agroindustrial and animal production and reduce feeding costs without competing with human food. According to Wilkinson (2011), the potential use of ingredients as human food of the diet based on by-products was $40 \%$ lower compared with the control diet. Additionally, the by-product based diet was cheaper $(80 € / \mathrm{t})$. Feeding the diet based on by-products to dairy goats had no negative effect on nutrient utilization, milk yield or ruminal fermentation, and resulted in more milk fat and protein. The milk from the goats fed the by-products diet was richer in unsaturated FA, compared with the milk from goats fed the control diet. A wide list of health benefits have been attributed to those FA, especially to polyunsaturated FA (Parodi, 2009; Banni et al., 2003). For that reason, as an extra positive effect of feeding by-products, the milk from animals receiving such diets could be considered healthier. Some authors have speculated that feeding agroindustrial by-products could reduce methane emissions due to the presence of biocompunds in the by-products (Vasta et al., 2009; Newbold et al., 2005). However, we did not observe any antimethanogenic effect. Nevertheless, the environmental benefit of utilizing agroindustrial by-product is still considerable even though it did not decrease emissions of greenhouse gases. All in one, feeding animals with diets base in by-products could contribute to improve the sustainability of livestock systems (Pascual Vidal, 2015; del Prado et al., 2013).

It is clear, that in vitro and in situ methods are useful to determine the nutritive value of feedstuffs. Although in vivo methods are more accurate, they are much more expensive. As already stated, there are plenty of agroindustrial by-products available today and studying their nutritive value with in vivo methods is not feasible, and therefore in vitro and in situ methods are being used to study their nutritive value. Nevertheless, these methods are still expensive and require considerable amounts of funds and workforce. Furthermore, experimental animals are needed to perform in vitro and in situ studies. On the other hand, there are tools that could help to predict the nutritive value of feeds which would facilitate their inclusion in diets. This is especially interesting for agroindustrial by-prducts, especially taking into account the wide range of by-products available. Among these tools, regression analyses have been one of the 
most commonly used and they allow to obtain equations similar to those obtained in the Experiment 2 (Paper 2), in which fermentation parameters were estimated from chemical composition, which is easier and cheaper to determine. However, the data used to obtain these equations require fulfilling some statistical assumptions which are not always satisfied, and predictions obtained from these equations are not always accurate.

As technology advances, new tools are available to the user which could provide new methods to predict the nutritive value of feeds. One of these new tools are Neural Networks. Processing the data with neural networks does not require any statistical assumption or condition, which means that information from very heterogeneous sources can be processed. This is a very interesting approach for evaluating groindustrial by-products, as they are a very heterogeneous group of potential feeds. What is more interesting of Neural Networks is that the more information is provided, the better are the results obtained. As an example, Figure 2 shows a prediction of the AGPR of the four OC samples used to test the accuracy of this procedure (See Materials and methods). When data from TP was included in neural network (Figure 3$)$, the precision increased and was higher $\left(\mathrm{R}^{2}=0.978\right.$; slope close to 1) than that obtained in the Experiment 2 (Paper 2) from regression analyses. In addition, this model could be used to predict fermentation parameters of both OC and TP. These results suggest that neural networks could be a good tool to predict the nutritive value of agroindustrial by-products, as usually the nutritive value is influenced by different chemical fraction, as shown in the Experiments 1 to 4 (Paper 1, 2, 5 and 3) of this Tehsis. In the future, these models might be improved by including more data and could provide a universal method to estimate the nutritive value of by-products and other feeds. The possibility of predicting in vivo parameters, such as feed intake or nutrient digestibility should also be explored. 


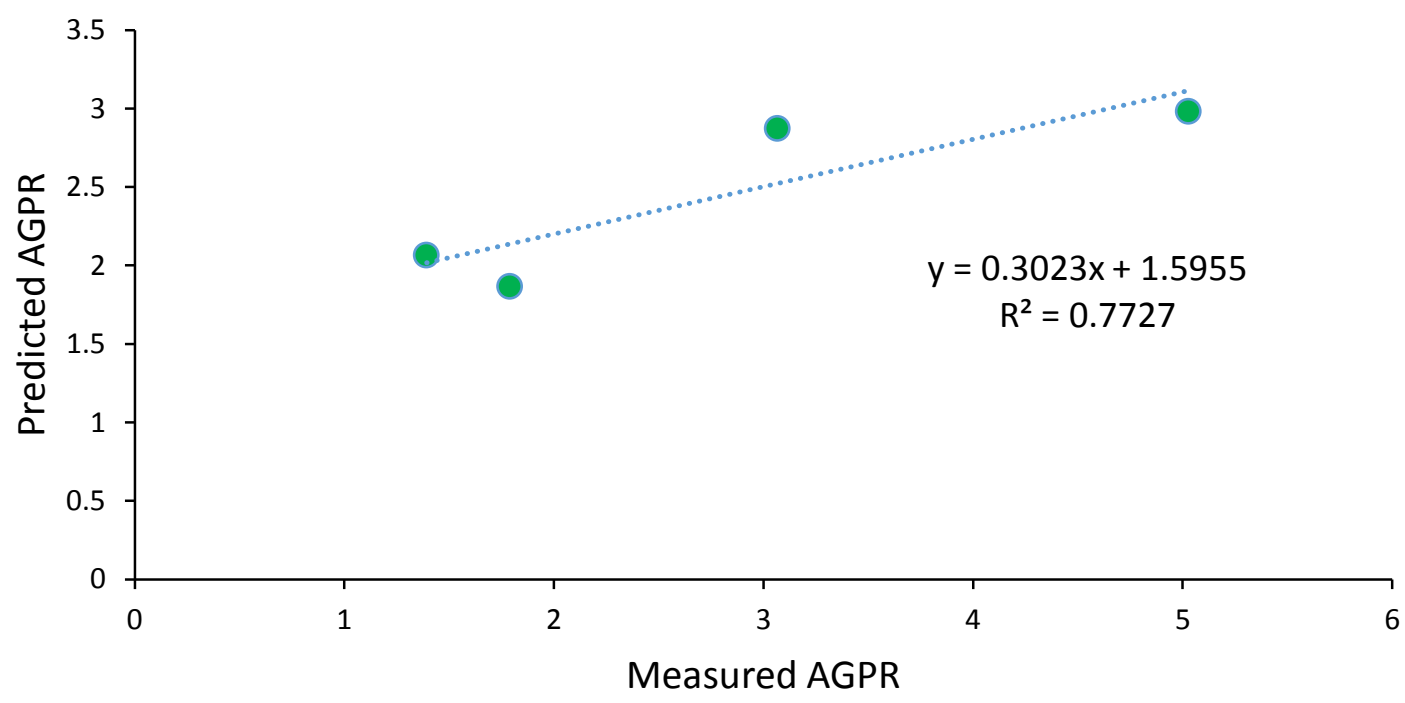

Figure 2. Prediction of AGPR with a neural network including olive cake (OC) data.

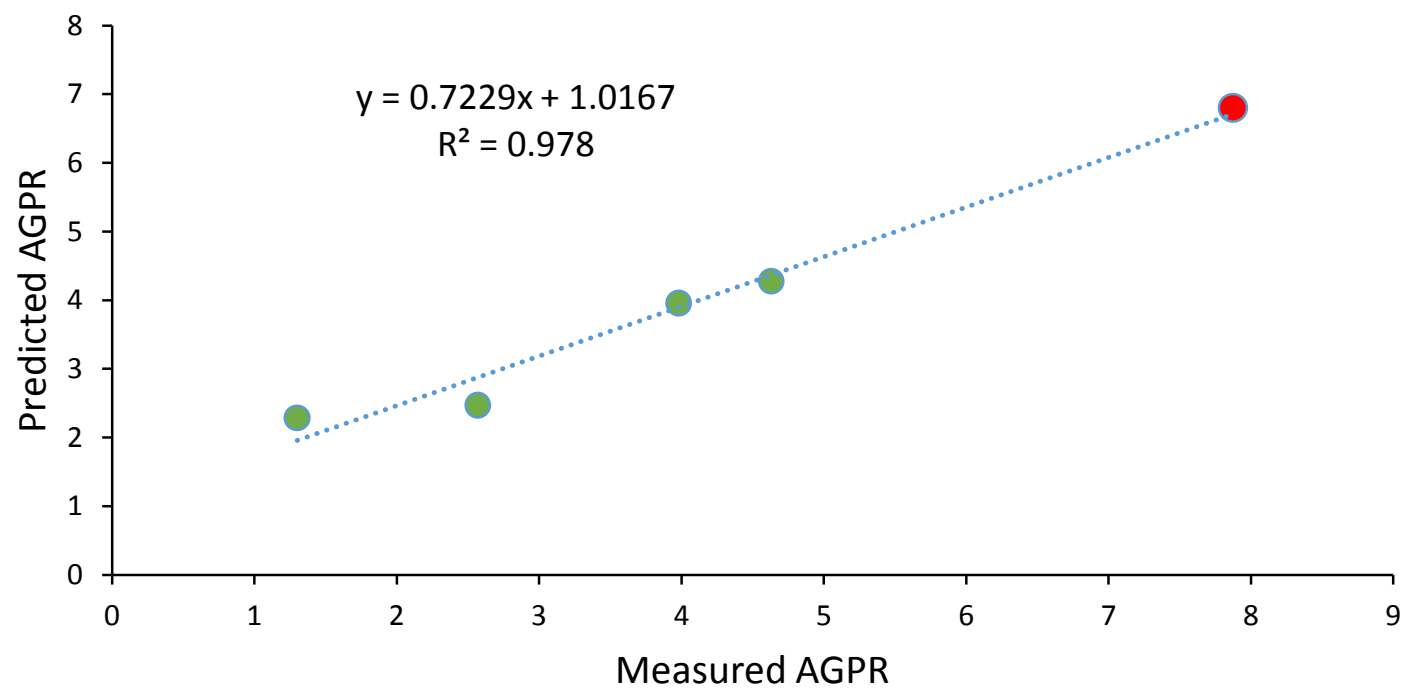

Figure 3. Prediction of AGPR with a neural network including olive cake (OC; Green dots) and tomato pomace (TP; Red dot) data. 
$\sim 152 \sim$ 


\section{CONCLUSIONS}

1. The nutritive value of olive cake was low, but it was markedly affected by processing, storage time of alperujo before processing, and particle size. Ruminal degradability of cyclone olive cake was as average 1.3 times greater than that of crude and exhausted olive cake obtained at the same storage time. For all types of olive cake, ruminal degradability decreased with advancing storage time, and therefore early processing is recommended. Olive cake samples samples having more than $3 \mathrm{~mm}$ or less than $1 \mathrm{~mm}$ showed greater fermentability than those measuring 2 and $3 \mathrm{~mm}$.

2. In vitro ruminal fermentation parameters of olive cake can be predicted from the type of olive cake and its content in sugars and total soluble polyphenols. The same ruminal paraemters can be predicted from olive cake type and storage time, but the equations had lower $\mathrm{R}^{2}$ and greater residual standar deviation values than those involving chemical fractions.

3. There was little variability in chemical composition and in vitro rumen fermentation of tomato pomace samples obtained from two processing plants at different times over the tomato campaign. Although tomato pomace had relatively high protein content (average $160 \mathrm{~g} / \mathrm{kg}$ dry matter), both rumen degradability and in vitro intestinal digestibility of the undegraded protein were low (average 510 and $459 \mathrm{~g} / \mathrm{kg}$, respectively). In vitro results indicated that dried TP could be included up to $180 \mathrm{~g} / \mathrm{kg}$ in a high-concentrate diet without negative effects on rumen fermentation.

4. The use of cetyltrimethylammonium bromide in the analysis of acid detergent insoluble nitrogen (ADIN) resulted in an overestimation of the ADIN fraction, questioning the use of $\mathrm{ADIN}$ as a parameter indicative of nitrogen availability. The overestimation was greater for high-fibre samples and was reduced with increasing lignification of the cell wall.

5. A mixture of corn DDGS, DCP and EOC (in proportions of 41, 41 and 18\%, respectively) could replace $44 \%$ of cereal grains and protein feeds in the concentrate for dairy goats without compromising feed intake, nutrient utilization or ruminal fermentation, and resulted in greater milk fat and protein production, as well as in a more unsaturated and potentially healthier milk FA profile. 
154 
Chapter VIII. REFERENCES 
Abbeddou, S., Rischkowsky, B., Hilali, M. E. D., Haylani, M., Hess, H. D., and Kreuzer, M. (2015). Supplementing diets of Awassi ewes with olive cake and tomato pomace on farm recovery of effects on yield, composition and fatty acid profile of the milk. Tropical Animal Health and Production 47, 145-152.

Abbeddou, S., Rischkowsky, B., Richter, E. K., Hess, H. D., and Kreuzer, M. (2011). Modification of milk fatty acid composition by feeding forages and agro-industrial byproducts from dry areas to Awassi sheep. Journal of Dairy Science 94, 4657-4668.

Abecia, L., Toral, P. G., Martin-García, A.I., Martínez, G., Tomkins, N. W., MolinaAlcaide, E., Newbold, C. J., and Yánez-Ruíz, D. R. (2012). Effect of bromochloromethane on methane emission, rumen fermentation pattern, milk yield, and fatty acid profile in lactating dairy goats. Journal of Dairy Science 95, 2027-2036.

Aguilera, J. F., Prieto, C., and Fonollá, J. (1990). Protein and energy metabolism of lactating Granadina goats. British Journal of Nutrition 63, 165-75.

Alancay, M. M., Lobo, M. O., Quinzio, C. M., and Iturriaga, L. B. (2017). Extraction and physicochemical characterization of pectin from tomato processing waste. Journal of Food Measurement and Characterization 11, 2119-2130.

Alburquerque, J. A., Gonzálvez, J., García, D., and Cegarra, J. (2004) Agrochemical characterization of "alperujo", a solid by-products of the two-phase centrifugation method for olive oil extraction. Bioresource Technology 91, 195-200.

Aldai, N., de Renobales, M., Barron, L. J. R., and Kramer, J. K. G. (2013). What are the trans fatty acids issues in foods after discontinuation of industrially produced trans fats? Ruminant products, vegetable oils, and synthetic supplements. European Journal of Lipid Science and Technology 115, 1378-1401.

Alfonso, D., Brines, N., Peñalvo, E., Vargas, C. A., Pérez-Navarro, A., Gómez, P., Pascual, A., and Ruiz, B. (2010). In "Cuantificación de materias primas alimentarias de origen vegetal”, pp. 80. MINECO.

Al-Jassim, R. A. M., Awadeh, F. T., and Abodabos, A. (1997). Supplementary feeding value of urea-treated olive cake when fed to growing Awasi lambs. Animal Feed Science and Technology 64, 287-292.

Álvarez, R., Meléndez-Martínez, A. J., Vicario, I. M., and Alcalde, M. J. (2015). Carotenoid and vitamin a contents in biological fluids and tissues of animals as an effect of the diet: A review. Food Reviews International 31, 319-340. 
Álvarez-Rodríguez, J., Muñoz, F., and Margalida, J. (2009). Nutritive value of crude and extracted two-stage olive cakes produced in Aragón (Spain). Revista Electrónica de Veterinaria 10, 1-7.

Amiot, M. J., Fleuriet, A., and Macheix, J. (1986). Importance and evolution of phenolic compounds in olive during growth and maturation. Journal of Agricultural and Food Chemistry 34, 823-826.

Amro, B., Aburjai, T., and Al-Khalil, S. (2002). Antioxidative and radical scavenging effects of olive cake extracts. Fitoterapia 73, 456-461.

Anderson, J. L., Schingoethe, D. J., Kalscheur, K. F., and Hippen, A. R. (2006). Evaluation of dried and wet distillers grains included at two concentrations in the diets of lactating dairy cows. Journal of Dairy Science 89, 3133-3142.

Arco-Pérez, A., Ramos-Morales, E., Abecia, L., Yáñez-Ruiz, D. R., and Martín-García, A. I. (2013). Rumen in vitro fermentation of agriculture by-products with potential use in feeding goats. ITEA 1, 246-248.

Arco-Pérez, A., Ramos-Morales, E., Yáñez-Ruiz, D. R., Abecia, L., and Martín-García, A. I. (2017). Nutritive evaluation and milk quality of including of tomato or olive byproducts silages with sunflower oil in the diet of dairy goats. Animal Feed Science and Technology 232, 57-70.

Arroyo, J. M., and González, J. (2013). Effects of microbial colonization in the rumen on concentration and degradability estimates of fibre fractions. Livestock Science 153, 101-107.

Ashes, J. R., Welch, P. St. V., Gulati, S. K., Scott, T. W., Brown, G. H., and Blakeley, S. (1992). Manipulation of the fatty acid composition of milk by feeding protected canola seeds. Journal of Dairy Science 75, 1090-1096.

Association of Official Analytical Chemists (AOAC). (2005). Official Methods of Analysis, 18th ed. AOAC International.

Awawdeh, M. S., and Obeidat, B. S. (2013). Treated olive cake as a non-forage fiber source for growing awassi lambs: Effects on nutrient intake, rumen and urine $\mathrm{pH}$, performance, and carcass yield. Asian-Australasian Journal of Animal Science 2, 661666.

Awawdeh, M. S., and Obeidat, B. S. (2011). Effect of supplemental exogenous enzymes on performance of finishing Awassi lambs fed olive cake-containing diets. Livestock 
Science 138, 20-24.

Aydemir, G., Kasiri, Y., Bartók, E. M., Birta, E., Fröhlich, K., Böhm, V., and Rühl, R. (2016). Lycopene supplementation restores vitamin A deficiency in mice and possesses thereby partial pro-vitamin A activity transmitted via RAR signalling. Molecular Nutrition and Food Research 60, 2413-2420.

Balcells, J., Guada, J., Peiró, J., and Parker, D. (1992). Simultaneous determination of allantoin and oxypurines in biological fluids by high-performance liquid chromatography. Journal of Chromatography B 575, 153-157.

Barroso, F. G., Megías-Rivas, M. D., Martínez-Teruel, A., Madrid-Sánchez, J., and Hernández, F. (2017). El potencial del ensilado de tomate en la alimentación de pequeños rumiantes. Albéitar publicación veterinaria independiente 1, 68-71.

Barroso, F. G., Martínez, T., Megías, D., Madrid, J., and Hernández, F. (2006). Conservación y valoración de la pulpa de tomate ensilada para alimentación animal. In "XXXI Jornadas Científicas y X Internacionales de La Sociedad Españ la de Ovinotecnica y Caprinotecnia”. Consejería de Agricultura y Ganadería.

Bauman, D. E., and Griinari, J. M. (2003). Nutritional regulation of milk fat synthesis. Annual Review of Nutrition 23, 203-227.

Bekhit, A. E. D., Hopkins, D. L., Fahri, F. T., and Ponnampalam, E. N. (2013). Oxidative processes in muscle systems and fresh meat: Sources, markers, and remedies. Comprehensive Reviews in Food Science and Food Safety 12, 565-597.

Belović M. M., Girones-Vilaplana A., Moreno D. A., Milovanovic I. L. J., Novakovic A. R., and Karaman M. A. (2016). Tomato (Solanum Lycopersicum L.) processing main product (juice) and by-product (pomace) bioactivity potential measured as antioxidant activity and angiotensin-converting enzyme inhibition. Journal of Food Processing and Preservation 40, 1229-1237.

Ben Salem, H. (2010). Nutritional management to improve sheep and goat performances in semiarid regions. Revista Brasileira de Zootecnia 39, 337-347.

Ben Salem, H., and Znaidi, I. (2008). Partial replacement of concentrate with tomato pulp and olive cake-based feed blocks as supplements for lambs fed wheat straw. Animal Feed Science and Technology 147, 206-222.

Ben Salem, H., and Nefzaoui, A. (2003). Feed blocks as alternative supplements for sheep and goats. Small Ruminant Research 49, 275-288. 
Benchaar, C., Hassanat, F., Gervais, R., Chouinard, P. Y., Julien, C., Petit, V., and Massé, D. I. (2013). Effects of increasing amounts of corn dried distillers grains with solubles in dairy cow diets on methane production, ruminal fermentation, digestion, $\mathrm{N}$ balance, and milk production. Journal of Dairy Science 96, 1-15.

Bessa, R. J. B., Alves, S. P., Jerònimo, E., Alfaia, C. M., Prates, J. A. M., and SantosSilva, J. (2007). Effect of lipid supplements on ruminal biohydrogenation intermediates and muscle fatty acids in lamb. European Journal of Lipid Science and Technology 109, 868-883.

Bianchi, G. (2003). Lipids and phenols in table olives. European Journal of Lipid Science and Technology 105, 229-242.

Blekas, G., Vassilakis, C., Harizanis, C., Tsimidou, M., and Boskou, D. G. (2002). Biophenols in table olives. Journal of Agricultural and Food Chemistry 50, 36883692

Botineştean, C., Gruia, A. T., and Jianu, I. (2014). Utilization of seeds from tomato processing wastes as raw material for oil production. Journal of Material Cycles and Waste Management 17, 118-124.

Broderick, G. A., Wallace, R. J., and Ørskov, E. R. Control of rate and extent of protein degradation. California, USA, ed. Tsuda, T., Susaki, Y., Kawashima, R. 2000. In "Physiological Aspects of Digestion and Metabolism in Ruminants". pp. 541-592. Academic Press.

Brodowski, D., and Geisman, J. R. (1980). Protein content and amino acid composition of protein of seeds from tomatoes at various stages of ripeness. Journal of Food Science 45, 228-229.

Brown, H. E., Meredith, F. I., Saldama, G., and Stephens, T. S. (1970). Freeze peeling improves quality of tomatoes. Journal of Food Science 35, 485-488.

Buccioni, A., Pauselli, M., Viti, C., Minieri, S., Pallara, G., Roscini, V., Rapaccini, S., Marinucci, M. T., Lupi, P., Conte, G., and Mele, M. (2015). Milk fatty acid composition, rumen microbial population, and animal performances in response to diets rich in linoleic acid supplemented with chestnut or quebracho tannins in dairy ewes. Journal of Dairy Science 98, 1145-1156.

Bueno, M. S., Ferrari Jr., E., Bianchini, D., Leinz, F. F., and Rodrigues, C. F. C. (2002). Effect of replacing corn with dehydrated citrus pulp in diets of growing kids. Small 
Ruminant Research 46, 179-185.

Cais-Sokolińska, D., Wójtowski, J., Pikul, J., Danków, R., Majcher, M., Teichert, J., and Bagnicka, E. (2015). Formation of volatile compounds in kefir made of goat and sheep milk with high polyunsaturated fatty acid content. Journal of Dairy Science $\mathbf{9 8 ,}$ 6692-6705.

Calsamiglia, S., Ferret, A., and Bach, A. (2016). Valor Nutritivo de Forrajes y Subproductos Húmedos, Vol. 2. FEDNA.

Caluya, R. R., Sair, R. R., Recta, G. M. R., and Balneg, B. B. (2003). Tomato Pomace as Feed for Livestock and Poultry. Don Mariano Marcos Memorial State University, Bacnotan, La Union, Philippines.

Canamasas, P., and Ravetti, L. M. (2014). Evaluation of traditional and new processing aids for olive oil extraction. Acta Horticulturae 1057, 677-684.

Cantarelli, P. R., Regitano-d'Arce, M. A. B., and Palma, E. R. (1993). Physicochemical characteristics and fatty acid composition of tomato seed oils from processing wastes. Scientia Agricola 50, 117-120.

Capucci, A., Alves, S. P., Bessa, R. J. B., Buccioni, A., Mannelli, F., Pauselli, M., Viti, C., Pastorelli, R., Roscini, V., Serra, A., Conte, G., and Mele, M. (2018). Effect of increasing amounts of olive crude phenolic concentrate in the diet of dairy ewes on rumen liquor and milk fatty acid composition. Journal of Dairy Science 101, 49925005 .

Carro, M. D., Ranilla, M. J., Martín-García, A. I., and Molina-Alcaide, E. (2009). Comparison of microbial fermentation of high- and low-forage diets in sheep rumen and two types of fermenters. Animal 3-4, 527-534.

Centro de Actividades Regionales para la Producción Limpia. (2000). In "Prevención de La Contaminación en la Producción de Aceite de Oliva”.

Chilliard, Y., Glasser, F., Ferlay, A., Bernard, L., Rouel, J., and Doreau, M. (2007). Diet, rumen biohydrogenation and nutritional quality of cow and goat milk fat. European Journal of Lipid Science and Technology 109, 828-855.

Chiofalo, B., Liotta, L., Zumbo, A., and Chiofalo, V. (2004). Administration of olive cake for ewe feeding: Effect on milk yield and composition. Small Ruminant Research 55, 169-176.

Clark, J. H., Murphy, M. R., and Crooker, M. R. (1987). Symposium: alternative feed 
sources for dairy cattle. Supplying the protein needs of dairy cattle from by-product feeds. Journal of Dairy Science 70, 1092.

Consejo Oleícola Internacional. (2018). Olive oil performance in 2017/18 and olive oil and table olive estimates 2018/19. Market Newsletter $N^{\circ}$ 130. [consulted 05/04/2019]. Available in: $\quad$ www.internationaloliveoil.org/.../14007-market-newsleteerseptember.pdf

Correia, C. S., Alfaia, C. M., Madeira, M. S., Lopes, P. A., Matos, T. J. S., Cunha, L. F., Prates, J. A. M., and Freire, J. P. B. (2017). Dietary inclusion of tomato pomace improves meat oxidative stability of young pigs. Journal of Animal Physiology and Animal Nutrition 101, 1215-1226.

De Blas, C., Rebollar, P.G., and Mateos, G.G. (2015). In "XXXI Curso de especialización FEDNA revisión 3a edición Tablas FEDNA”, pp. 67-107. Fundación Española Para E1 Desarrollo de la Nutrición Animal.

De Blas, C., Mateos, G. G. and García Rebollar, P. (2010). Tablas FEDNA de composición y valor nutritivo de alimentos para la fabricación de piensos compuestos. [consulted 08/06/2019]. Available in: http://www.fundacionfedna.org/tablas-fednacomposicion-alimentos-valor-nutritivo.

Del Prado, A., Mas, K., Pardo, G., and Gallejones, P. (2013). Modelling the interactions between $\mathrm{C}$ and $\mathrm{N}$ farm balances and GHG emissions from confinement dairy farms in northern. Science of The Total Environment 465, 156-165.

Del Valle, M., Cámara, M., and Torija, M. E. (2008). Chemical characterization of tomato pomace. Journal of the Science of Food and Agriculture 86, 1232-1236.

Demeyer, D. Quantitative aspects of microbial metabolism in the rumen and hindgut. Paris, France, ed. Jouany, J. P. 1991. In "Rumen Microbial Metabolism and Ruminant Digestion". pp. 217-237. INRA Editions.

Denek, N., and Can, A. (2006) Feeding value of wet tomato pomace ensiled with wheat straw and wheat grain for Awassi sheep. Small Ruminant Research 65, 260-265.

DePeters, E. J., Fadel, J. G., Arana, M. J., Ohanesian, N., Etchebarne, M. A., Hamilton, C. A., Hinders, R. G., Maloney, M. D., Old, C. A., Riordan, T. J., Perez-Monti, H., and Pareas, J. W. (2000). Variability in the Chemical Composition of Seventeen Selected By-Product Feedstuffs Used by the California Dairy Industry. The Professional Animal Scientist 16, 69-99. 
Descalzo, A. M., and Sancho, A. M. (2008). A review of natural antioxidants and their effects on oxidative status, odour and quality of fresh beef produced in Argentina. Meat Science 79, 423-436.

Dewhurst, R. J., Shingfield, K. J., Lee, M. R. F., and Scollan, N. D. (2006). Increasing the concentrations of beneficial polyunsaturated fatty acids in milk produced by dairy cows in high-forage systems. Animal Feed Science and Technology 131, 168-206.

Doreau, M., and Ferlay, A. (1994). Digestion and utilisation of fatty acids by ruminants. Animal Feed Science and Technology 45, 379-396.

Drouliscos, N. J. (1976). Nutritional evaluation of the protein of dried tomato pomace in the rat. British Journal of Nutrition 36, 449-456.

Edionwe, A. O., and Owen, F. G. (1989). Relation of intake to digestibility of diets containing soyhulls and distillers dried grains. Journal of Dairy Science 72, 1786.

Elbadrawy, E., and Sello, A. (2016). Evaluation of nutritional value and antioxidant activity of tomato peel extracts. Arabian Journal of Chemistry 9, S1010-S1018.

Ensminger, M. E., Oldfield, J. E., and Heinemann, W. W. (1990). Feeds and Nutrition, 2nd ed. The Ensminger Publishing Company.

FAO. (2018). FAOSTAT. [consulted 17/06/2019]. Available in http://www.fao.org/faostat/en/\#data/QC

FAO. (2016). FAOSTAT. [consulted 16/04/2018]. Available in: http://www.fao.org/faostat/zh/\#search/tomato

Farvid, M. S., Ding, M., Pan, A., Sun, Q., Chiuve, S. E., Steffen, L. M., and Hu, F. B. (2014). Dietary linoleic acid and risk of coronary heart disease: A systematic review and meta-analysis of prospective cohort studies. Circulation 130, 1568-1578.

Faustman, C., Sun, Q., Mancini, R., and Suman, S. P. (2010). Myoglobin and lipid oxidation interactions: Mechanistic bases and control. Meat Science 86, 86-94.

Feedipedia. (2019). Database. [consulted 13/07/2019]. Available in: http://www.feedipedia.org

Feedipedia. (2018). Orujo de tomate, pieles de tomate y semillas de tomate. [consulted 11/03/2018]. Available in: https://www.feedipedia.org/content/feeds? category=13592

Ferlay, A., Martin, B., Lerch, S., Gobert, M., Pradel, P., and Chilliard, Y. (2010). Effects of supplementation of maize silage diets with extruded linseed, vitamin $\mathrm{E}$ and plant extracts rich in polyphenols, and morning v. evening milking on milk fatty acid 
profiles in Holstein and Montbeliarde cows. Animal 4, 627-640.

Filya, I., Hanoglu, H., Canbolat, Ö., and Sucu, E. (2006). Researches on feed value and using possibilities in lamb fattening of dried olive cake 2. Effects on fattening performance of lambs. Uludağ Üniversitesi Ziraat Fakültesi Dergisi 20, 13-23.

Firkins, J. L., Yu, Z., and Morrison, M. (2007). Ruminal nitrogen metabolism: perspectives for integration of microbiology and nutrition for dairy cows. Journal of Dairy Science 90 Suppl 1, E1-16.

Firkins, J. L., Berger, L. L., Fahey Jr., G. C., and Merchen, N. R. (1984). Ruminal nitrogen degradability and escape of wet and dry distillers grains and wet and dry corn gluten feeds. Journal of Dairy Science 67, 1936.

Folch, J., Lees, M., and Stanley, G. H. S. (1957). A simple method for the isolation and purification of total lipides from animal tissues. Journal of Biological Chemistry 226, 497-509.

Fondevila, M., Guada, J. A., Gasa, J., and Castrillo, C. (1994). Tomato pomace as a protein supplement for growing lambs. Small Ruminant Research 13, 117-126.

Friedman, M. (1996) Food browning and its prevention: an overview. Journal of Agricultural and Food Chemistry 44, 631-653.

Garcia, E., and Barrett, D. M. (2006). Peelability and yield of processing tomatoes by steam or lye. Journal of Food Processing and Preservation 30, 3-14.

García-Inza, G. P., Castro, D. N., Hall, A. J., and Rousseaux, M. C. (2014). Responses to temperature of fruit dry weight, oil concentration, and oil fatty acid composition in olive (Olea europea L. var. 'Arauco'). European Journal of Agronomy 54, 107-115.

García-Martínez, R., Ranilla, M. J., Tejido, M. L., and Carro, M. D. (2005). Effects of disodium fumarate on in vitro rumen microbial growth, methane production and fermentation of diets differing in their forage concentrate ratio. British Journal of Nutrition 94, 71-77.

Gargallo, S., Calsamiglia, S., and Ferret, A. (2006). Technical note: A modified threestep in vitro procedure to determine intestinal digestion of proteins. Journal of Animal Science 84, 2163-2167.

Gasa, J., Castrillo, C., and Guada, J. A. (1988). Nutritive value for ruminants of the canning industry by-products: Tomato pomace and pepper residues. Investigación Agraria, Producción y Sanidad Animales 3, 57-73. 
Giovanelli, G., and Paradiso, A. (2002). Stability of dried and intermediate moisture tomato pulp during storage. Journal of Agricultural and Food Chemistry 50, 72777281.

Giozelgiannis, A., Tsiklidi, K., and Katanos, I. (1978). The olive meal in the feeding of fattening lambs. Agricultural Research 2, 223-233.

Giuffrè, A. M., and Capocasale, M. (2016). Physicochemical composition of tomato seed oil for an edible use: the effect of cultivar. International Food Research Journal 23, 583-591.

Goering, H. K., Gordon, C. H., Hemken, R. W., Waldo, D. R., Van Soest, P. J., and Smith, L. W. (1972). Analytical estimates of nitrogen digestibility in heat damaged forages. Journal of Dairy Science 55, 1275-1280.

Goering, M. K., and Van Soest, P. J. (1970). Forage Fiber Analysis (Apparatus, Reagents, Procedures and Some Applications). In "Agricultural Handbook; Agriculture Handbook No. 379”. Agricultural Research Services.

Gómez-Cortés, P., Frutos, P., Mantecón, A. R., Juárez, M., de la Fuente, M. A., and Hervás, G. (2008). Milk production, conjugated linoleic acid content, and in vitro ruminal fermentation in response to high levels of soybean oil in dairy ewe diet. Journal of Dairy Science 91, 1560-1569.

Griinari, J. M., Corl, B. A., Lacy, C. A., Chouinard, P. Y., Nurmela, K. V. V., and Bauman, D. E. (2000). Conjugated linoleic acid is synthesized endogenously in lactating dairy cows by delta-9 desaturase. Journal of Nutrition 130, 2285-2291.

Guardia, G., Vallejo, A., Cardenas, L. M., Dixon, E. R., and García-Marco, S. (2018). Fate of $15 \mathrm{~N}$-labelled ammonium nitrate with or without the new nitrification inhibitor DMPSA in an irrigated maize crop. Soil Biology and Biochemistry 116, 193-202.

Guevara-González, J., Mouhbi, R., Arroyo, J. M., Alvir, M. R., and González, J. (2015). Effects of correcting for microbial contamination and the use of sodium sulphite in NDF analyses on the ruminal fibre degradability of several feeds. The Journal of Agricultural Science Cambridge 153, 361-370.

Habeed, A. A. M., Gad, A. E., EL-Tarabany, A. A., Mustafa, M, M., and Atta, M. A. A. (2017). Using of Olive Oil By-Products in Farm Animals Feeding. International Journal of Scientific Research in Scienceand Technology 6, 57-68.

Hadjipanayiotou, M. (1994). Voluntary intake and performance of ruminant animals 
offered poultry litter-olive cake silage. Livestock Research for Rural Development 6, $1-9$.

Herrera, P. G., Sanchez-Mata, M. C., and Camara, M. (2010). Nutritional characterization of tomato fiber as a useful ingredient for food industry. Innovative Food Science and Emerging Technologies 11, 707-711.

Heuzé, V., Tran, G., Hassoun, P., and Lebas, F. (2018). Pulpa de cítricos, seca. Feedipedia. [consulted 16/05/2019]. Available in: https://www.feedipedia.org/node/680

Heuzé, V., Tran, G., Sauvant, D., Noblet, J., Renaudeau, D., Bastianelli, D., Lessire, M., and Lebas, F. (2015). Granos de destilería de maíz. Feedipedia. [consulted 22/5/2019]. Available in: https://www.feedipedia.org/node/71

Hodgson, J. M., Wahlqvist, M. L., Boxall, J. A., and Balaz, N. D. (1996). Platelet trans fatty acids in relation to angiographically assessed coronary artery disease. Atherosclerosis 120, 147-154.

Hoover, M. W., and Dennison, R. A. (1957). Preliminary studies on the utilization of cull tomatoes. Proceedings of the Florida State Horticultural Society 70, 211-214.

Ibáñez, C., Criscioni, P., Arriaga, H., Merino, P., Espinós, F. J., and Fernández, C. (2016). Murciano-Granadina Goat Performance and Methane Emission after Replacing Barley Grain with Fibrous By-Products. PLoS One 11(3):e0151215.

Jacobsen, C., Let, M. B., Nielsen, N. S., and Meyer, A. S. (2008). Antioxidant strategies for preventing oxidative flavor deterioration of food enriched with n-3 polyunsaturated lipids: A comparative evaluation. Trends in Food Science and Technology 19, 76-93.

Janssen, P. H. (2010). Influence of hydrogen on rumen methane formation and fermentation balances through microbial growth kinetics and fermentation thermodynamics. Animal Feed Science and Technology 160, 1-22.

Jiang, H., Wang, Z., Ma, Y., Qu, Y., Lu, X., Guo, H., and Luo, H. (2015a). Effect of dietary lycopene supplementation on growth performance, meat quality, fatty acid profile and meat lipid oxidation in lambs in summer conditions. Small Ruminant Research 131, 99-106.

Jiang, H., Wang, Z., Ma, Y., Qu, Y., Lu, X., and Luo, H. (2015b). Effects of dietary lycopene supplementation on plasma lipid profile, lipid peroxidation and antioxidant 
defense system in feedlot Bamei lamb. Asian-Australasian Journal of Animal Sciences 28, 958-965.

Johnson, K. A., and Johnson, D. E. (1995). Methane emissions from cattle. Journal of Animal Science 73, 2483-2492.

Kale, P. N., and Adsule, P. G. (1995). Citrus. New York, USA, ed. Salunkhe, D. K., Kadam, S. S. 1995. In "Handbook of Fruit Science and Technology: Production, Composition, Storage, and Processing”. pp. 39-65. Marcel Dekker.

Kamazani, N. A., Tavakolipour, H., Hasani, M., and Amiri, M. (2014). Evaluation and analysis of the ultrasound-assisted extracted tomato seed oil. Journal of Food Biosciences and Technology 4, 57-66.

Kaur, D., Sogi, D. S., Garg, S. K., and Bawa, A. S. (2005). Flotation-cum-sedimentation system for skin and seed separation from tomato pomace. Journal of Food Engineering 71, 341-344.

Kelkel, M., Schumacher, M., Dicato, M., and Diederich, M. (2011). Antioxidant and anti proliferative properties of lycopene. Free Radical Research 45, 925-940.

Kim, Y., Mosier, N. S., Hendrickson, R., Ezeji, T., Blaschek, H., Dien, B., Cotta, M., Dale, B., and Ladisch, M. R. (2008). Composition of corn dry-grind ethanol byproducts: DDGS, wet cake, and thin stillage. Bioresource Technology 99, 5165-5176.

Kiosseoglou, B., and Boskou, D. (1989). The composition of free and esterified sterols in tomato seed oil. Oleagineux 44, 113-115.

Kleinschmit, D. H., Schingoethe, D. J., Hippen, A. R., and Kalscheur, K. F. (2007). Dried distillers grains plus solubles with corn silage or alfalfa hay as the primary forage source in dairy cows. Journal of Dairy Science $\mathbf{9 0 ,} 5587$.

Knoblich, M., Anderson, B., and Latshaw, D. (2005). Analyses of tomato peel and seed byproducts and their use as a source of carotenoids. Journal of the Science of Food and Agriculture 85, 1166-1170.

Koprivnjak, O., Brkić Bubola, K., and Kosić, U. (2016). Sodium chloride compared to talc as processing aid has similar impact on volatile compounds but more favorable on ortho-diphenols in virgin olive oil. European Journal of Lipid Science and Technology 118, 318-324.

Kotsampasi, B., Bampidis, V. A., Tsiaousi, A., and Christodoulou, C. (2017). Effects of dietary partly destoned exhausted olive cake supplementation on performance, carcass 
characteristics and meat quality of growing lambs. Small Ruminant Research 156, 3341.

Kramer, J. K. G., and Zhou, J. (2001). Conjugated linoleic acid and octadecenoic acids: Extraction and isolation of lipids. European Journal of Lipid Science and Technology 103, 594-600.

Kurokawa, Y., Shibata, H., Tateno, S., Kanda, S., Takaura, K., Ishida, S., and Itabashi, H. (2012). Rumen fermentation, milk production and conjugated linoleic acid in the milk of cows fed high fiber diets added with dried distillers grains with solubles. Animal Science Journal 84, 106-112.

Lanzani, A., Bondioli, P., Folegatti, L., Fedeli, E., Bontempo, V., Chiofalo, V., Panichi, G., and Dell'Orto, V. (1993). Impiego di sanse di olive integrate nell'alimentazione della pecora da latte: Effetti sulle produzioni quali-quantitative di latte. Rivista Italiana delle Sostanze Grasse 70, 375-383.

Latlief, S. J., and Knorr, D. (2010). Tomato seed protein concentrates: effects of methods of recovery upon yield and compositional characteristics. Journal of Food Science 48, 1583-1586.

Lindmark-Månsson, H., and Åkesson, B. (2000). Antioxidative factors in milk. British Journal of Nutrition 84(Suppl. 1), S103-S110.

López, M. C., Estellés, F., Moya, V. J., and Fernández, C. (2014). Use of dry citrus pulp or soybean hulls as a replacement for corn grain in energy and nitrogen partitioning, methane emissions, and milk performance in lactating Murciano-Granadina goats. Journal of Dairy Science 97, 7821-7832.

López-Gallego, F., Rodríguez-Meilán, J., and Rodríguez-Medina, P. L. (2015). Inclusion of tomato pulp silage in beef fattening diets. Technical and economic study. In "XVI Jornadas sobre Producción Animal. 19 y 20 mayo 2015". Volume I amp. II, pp. 236-238.

López-Parra, M., Regalado, B., Aceituno-Romo, O., and López-Gallego, F. (2011). Repercusión de la utilización de la pulpa de tomate en el pienso de cebo de corderos sobre la calidad de la canal y de la carne. Ganadería 28, 42-46.

Lu, Z., Wang, J., Gao, R., Ye, F., and Zhao, G. (2019). Sustainable valorisation of tomato pomace: A comprehensive review. Trends in Food Science and Technology 86, 172-187. 
Luciano, G., Pauselli, M., Servilli, M., Mourvaki, E., Serra, A., Monahan, F. J., Lanza, M., Priolo, A., Zinnai, A., and Mele, M. (2013). Dietary olive cake reduces the oxidation of lipids, including cholesterol, in lamb meat enriched in polyunsaturated fatty acids. Meat Science $\mathbf{9 3}, \mathbf{7 0 3 - 7 1 4 .}$

Luciano, G., Biondi, L., Pagano, R. I., Scerra, M., Vasta, V., López-Andrés, P., Valenti, B., Lanza, M., Priolo, A., and Avondo, M. (2012). The restriction of grazing duration does not compromise lamb meat colour and oxidative stability. Meat Science 92, 3035.

Lumpkins, B. S., and Batal, A. B. (2005). The bioavailability of lysine and phosphorus in distillers dried grains with solubles. Poultry Science 84, 581-586.

Luna, P., Bach, A., Juareza, M., and De la Fuente, M. A. (2008). Influence of diets rich in flax seed and sunflower oil on the fatty acid composition of ewes' milk fat especially on the level of conjugated linoleic acid, n3 and n6 fatty acids. International Dairy Journal 18, 99-107.

Machacek, K. J., and Kononoff, P. J. (2009). The relationship between acid detergent insoluble nitrogen and nitrogen digestibility in lactating dairy cattle. The Professional Animal Scientist 25, 701-708.

Madrid, J., Hernández, F., Pulgar, M. A., and Cid, J. M. (1996). Dried lemon as energetic supplement of diet based on urea-treated barley straw: effects on intake and digestibility in goats. Animal Feed Science and Technology 63, 89-98.

Maia, M. R., Chaudhary, L. C., Figueres, L., and Wallace, R. J. (2007). Metabolism of polyunsaturated fatty acids and their toxicity to the microflora of the rumen. Antonie Van Leeuwenhoek 91, 303-314.

Makkar, H. P. S. (2003). Effects and fate of tannins in ruminant animals, adaptation to tannins, and strategies to overcome detrimental effects of feeding tannin-rich feeds. Small Ruminant Research 49, 241-256.

MAPA. (2018). Anuario de estadística del Ministerio de Agricultura, Pesca y Alimentación 2017. [consulted 16/3/2019]. Available in: https://www.mapa.gob.es/estadistica/pags/anuario/2017/anuario/AE17.pdf

MAPA. (2019a). Producciones agrícolas. [consulted 16/3/2019]. Available in: https://www.mapa.gob.es/es/agricultura/temas/producciones-agricolas/frutas-yhortalizas/informacion_general.aspx 
MAPA. (2019b). Cereales: superficies y producciones, campaña 2018/2019. [consulted $22 / 5 / 2019]$. Available

in:

https://www.mapa.gob.es/va/agricultura/temas/producciones-agricolas/cultivosherbaceos/cereales/default.aspx

MAPAMA. (2018). Producciones agrícolas. Ministerio de Agricultura y Pesca Alimentación y Medio Ambiente. [consulted 13/05/2018]. Available in http://www.mapama.gob.es/es/ agricultura/temas/producciones-agricolas

Marcos, N. C., López, F., Molina-Alcaide, E., Carro, M. D. (2017). Variability in Chemical Composition and In Vitro Gas Production of Tomato Pomace. In "2nd World Conference of Innovation in Animal Nutrition Feed”. pp. 72-73.

Martin, C., Morgavi, D. P., and Doreau, M. (2010). Methane mitigation in ruminants: from microbe to the farm scale. Animal 4, 351-365.

Martin, B., Fedele, V., Ferlay, A., Grolier, P., Rock, E., Gruffat, D., and Chilliard, Y. (2004). Effects of grass-based diets on the content of micronutrients and fatty acids in bovine and caprine dairy products. Luzern, Switzerland, ed. Lúscher, A., Jeangros, B., Kessler, W., Huguenin, O., Lobsiger, M., Millar, N., Suter, D. In "Land use systems in grassland dominated regions. Proceedings of the 20th General Meeting of the European Grassland Federation”, pp 876-886.

Martínez-Pascual, J., and Fernández-Carmona, J. (1980). Composition of citrus pulp. Animal Feed Science and Technology 5, 1-10.

Martín-García, A. I., Yáñez-Ruiz, D. R., Moumen, A., and Molina Alcaide, E. (2004). Effect of polyethylene-glycol on the chemical composition and nutrient availability of olive (Olea europaea var. europaea) by-products. Animal Feed Science and Technology 114, 159-177.

Martín-García, A. I., Moumen, A., Yáñez-Ruiz, D. R., and Molina-Alcaide, E. (2003). Chemical composition and nutrients availability for goats and sheep of two-stages olive cake and olive leaves. Animal Feed Science and Technology 107, 61-74.

McAllister, T. A., and Newbold, C. J. (2008). Redirecting rumen fermentation to reduce methanogenesis. Australian Journal of Experimental Agriculture 48, 7-13.

McKeown, L. E., Chaves, A. V., Oba, M., Dugan, M. E. R., Okine, E., and McAllister, T. A. (2010). Effects of corn-, wheat- or triticale dry distillers' grains with solubles on in vitro fermentation, growth performance and carcass traits of lambs. Canadian 
Journal of Animal Science 90, 99-108.

Mechmeche, M., Kachouri, F., Chouabi, M., Ksontini, H., Setti, K., and Hamdi, M. (2017). Optimization of extraction parameters of protein isolate from tomato seed using response surface methodology. Food Analytical Methods 10, 809-819.

Mele, M., Serra, A., Pauselli, M., Luciano, G., Lanza, M., Pennisi, P., Conte, G., Taticchi, A., Esposto, S., and Morbidini, L. (2014). The use of stoned olive cake and rolled linseed in the diet of intensively reared lambs: effect on the intramuscular fattyacid composition. Animal 8, 152-162.

Mendez-Llorente, F., Aguilera-Soto, J., López-Carlos, M., Ramirez-Lozano, R., and Carrillo-Muro, G. (2014). Conservación de desechos de tomate fresco por ensilaje. Interciencia 39, 432-434.

Meneses, M., Megías, M. D., Madrid, J., Martínez-Teruel, A., Hernández, F., and Oliva, J. (2007). Evaluation of the phytosanitary, fermentative and nutritive characteristics of the silage made from crude artichoke (Cynara scolymus L.) by-product feeding for ruminants. Small Ruminant Research 70, 292-296.

Mioč, B., Pavić, V., Vnučec, I., Prpić, Z., Kostelić, A., and Sušić, V. (2007). Effect of olive cake on daily gain, carcass characteristics and chemical composition of lamb meat. Czech Journal of Animal Science 5, 31-36.

Molina-Alcaide, E., Morales-García, E. Y., Martín-García, A. I., Ben Salem, H., Nefzaoui, A., and Sanz-Sampelayo, M. R. (2010). Effects of partial replacement of concentrate with feed blocks on nutrient utilization, microbial $\mathrm{N}$ flow, and milk yield and composition in goats. Journal of Dairy Science 93, 2076-2087.

Molina-Alcaide, E., and Yáñez-Ruiz, D. R. (2008). Potential use of olive by-products in ruminant feeding: a review. Animal Feed Science and Technology 147, 247-264.

Molina-Alcaide, E., and Aguilera, J. E. (1988). Nutritive value of a soda-treated olive cake. Digestibility of cell wall components. Annales De Zootechnie 37, 63-72.

Morgavi, D. P., Forano, E., Martin, C., and Newbold, C. J. (2010). Microbial ecosystem and methanogenesis in ruminants. Animal 4, 1024-1036.

Morrissey, P. A., Sheehy, P. J. A., Galvin, K., Kerry, J. P., and Buckley, D. J. (1998). Lipid stability in meat and meat products. Meat Science 49, 73-86.

Mosley, E. E., Powell, G. L., Riley, M. B., and Jenkins, T. C. (2002). Microbial biohydrogenation of oleic acid to trans isomers in vitro. Journal of Lipid Research $\mathbf{4 3}$, 
290-296.

Nakamura, T., Klopfenstein, T. J., and Britton, R. A. (1994). Evaluation of acid detergent insoluble nitrogen as an indicator of protein quality in nonforage proteins. Journal of Animal Science 72, 1043-1048.

Navarro-Gonzalez, I., Garcia-Valverde, V., Garcia-Alonso, J., and Periago, M. J. (2011). Chemical profile, functional and antioxidant properties of tomato peel fiber. Food Research International 44, 1528-1535.

Nefzaoui, A., and Vanbelle, M. (1986). Effects of feeding alkali-treated olive cake on intake, digestibility and rumen liquor parameters. Animal Feed Science and Technology 14, 139-149.

Nefzaoui, A. (1985). Lignocellulosic wastes valorisation in ruminant feeding by alkali treatment. Application to olive cake. Ph.D. Thesis. Catholic University of Louvain, Louvain-la-Neuve, Belgium.

Nefzaoui, A. (1983). Study on the use of olive by-products as animal feeds in Tunisia (Etude de l'Utilisation des Sous-Produits de l'Olivier en Alimentation Animale en Tunisie). Animal Production and Health Division, FAO, Rome.

Newbold, C. J., López, S., Nelson, N., Ouda, J. O., Wallace, R. J., and Moss, A. R. (2007). Propionate precursors and other metabolic intermediates as possible alternative electron acceptors to methanogenesis in ruminal fermentation in vitro. British Journal of Nutrition 94, 27-35.

Newbold, C. J., López, S., Nelson, N., Ouda, J. O., Wallace, R. J., and Moss, A. R. (2005). Propionate precursors and other metabolic intermediates as possible alternative electron acceptors to methanogenesis in ruminal fermentation in vitro. British Journal of Nutrition 94, 27.

Nozière, P., Graulet, B., Lucas, A., Martin, B., Grolier, P., and Doreau, M. (2006). Carotenoids for ruminants: From forages to dairy products. Animal Feed Science and Technology 131, 418-450.

NRC. (2007). Nutrient Requirements of Small Ruminants: Sheep, Goats, Cervids, and New World Camelids, 6th ed. National Academy Press.

NRC. (2001). Nutrient Requirements of Dairy Cattle, 7th ed. National Academy of Sciences.

O'Connell, J. E., and Fox, P. F. (2001). Significance and applications of phenolic 
compounds in the production and quality of milk and dairy products: A review. International Dairy Journal 11, 103-120.

Panagiotis, E., Simitzis, S. G., and Deligeorgis, G. Chapter 8 - Agroindustrial ByProducts and Animal Products: A Great Alternative for Improving Food-Quality Characteristics and Preserving Human Health. ed. Holban, A. M., Grumezescu, A. M. 2018. In "Handbook of Food Bioengineering". pp. 253-290. Academic Press.

Paraskeva, P., and Diamadopoulos, E. (2006). Technologies for olive mill wastewater (OMW) treatment: a review. Journal of Chemical Technology and Biotechnology 81, 1475-1485.

Parr, A. J., and Bolwell, G. P. (2000). Phenols in the plant and in man. The potential for possible nutritional enhancement of the diet by modifying the phenols content or profile. Journal of the Science of Food and Agriculture 80, 985-1012.

Pascual-Vidal, A. (2015). Aplicaciones de los subproductos y casos de éxito en la gestión de subproductos Ponencia presentada en el Programa Taller FIAB. In "Gestión de Subproductos en la Industria Alimentaria".

Patumi, M., D’andria, R., Marsilio, V., Fontanazza, G., Morelli, G., and Lanza, B. (2002). Olive and olive oil quality after intensive monocone olive growing (Olea europaea L., cv. Kalmata) in different irrigation regimes. Food Chemistry 77, 27-34.

Pearson, D. (1976). The Chemical Analysis of Foods. London, UK.

Pecka-Kielb, E., Zachwieja, A., Miśta, D., Zawadzki, W., and Zielak-Steciwko, A. (2017). Use of Corn Dried Distillers Grains (DDGS) in Feeding of Ruminants. In "Frontiers in Bioenergy and Biofuels". pp. 495-511.

Pecka-Kiełb, E., Zawadzki, W., Zachwieja, A., Michel, O., Mazur, M., and Miśta, D. (2015). In vitro study of the effect of corn dried distillers grains with solubles on rumen fermentation in sheep. Polish Journal of Veterinary Sciences 18, 751-758.

Peiretti, P. G., Gai, F., Rotolo, L., Brugiapaglia, A., and Gasco, L. (2013). Effects of tomato pomace supplementation on carcass characteristics and meat quality of fattening rabbits. Meat Science 95, 345-351.

Pena, F., Tagari, H., and Satter, L. D. (1986). The effect of heat treatment of whole cottonseed on site and extent of protein digestion in dairy cows. Journal of Animal Science 62, 1423.

Porte, F. E., Manterola, B. H., Cerda, A. D., Sirhan, A. L., Mira, J. J., and Barbieri, S. 
M. (1993). Studies of the use of agroindustrial by-products in animal feeding. 1. Production performance of Hereford steers fed with diets that included increasing levels of tomato pomace. Avances en Producción Animal 18, 55-62.

Prieto, C., Aguilera, J. F., Lara, L., and Fonollá, J. (1990). Protein and energy requirements for maintenance of indigenous Granadina goats. British Journal of Nutrition 63, 155-163.

Rahbarpour, A., Palangi, V., Eivazi, P., and Jalili, M. (2012) Calculation of metabolizable protein and energy of tomato pomace by nylon bags and gas production data. The Journal of Experimental Biology 2, 822-825.

Rallo, L., M. Díez, C., Morales-Sillero, A., Miho, H., Priego-Capote, F., and Rallo, P. (2018). Quality of olives: A focus on agricultural preharvest factors. Scientia Horticulturae 233, 491-509.

Recio, I., Pérez-Rodríguez, M. L., Amigo, L., and Ramos, M. (1997). Study of the polymorphism of caprine milk caseins by capillary electrophoresis. Journal of Dairy Research 64, 515-523.

Robertson, J. B., and Van Soest, P. J. The detergent system of analysis and its application to human foods. New York, USA, ed. James, W. P. T., Theander, O. 1981. In "The Analysis of Dietary Fiber in Food". pp. 123-142. Marcel Dekker.

Rock, C., Yang, W., Goodrich-Schneider, R., and Feng, H. (2012). Conventional and alternative methods for tomato peeling. Food Engineering Reviews 4, 1-15.

Rodríguez, G., Lama, A., Rodríguez, R., Jiménez, A., Guillén, R., and FernándezBolaños, J. (2008). Olive stone an attractive source of bioactive and valuable compounds. Bioresource Technology 99, 5261-5269.

Romani, A., Mulinacci, N., Pinelli, P., Vincieri, F. F., and Cimato, A. (1999) Polyphenolic content in five tuscany cultivars of Olea europaea L. Journal of Agricultural and Food Chemistry 47, 964-967.

Romano, R., Masucci, F., Giordano, A., Spagna Musso, S., Naviglio, D., and Santini, A. (2010). Effect of tomato by-products in the diet of Comisana sheep on composition and conjugated linoleic acid content of milk fat. International Dairy Journal 20, 858862.

Romero-Huelva, M., Ramírez-Fenosa, M. A., Planelles-González, R., García-Casado, P., and Molina-Alcaide, E. (2017). Can by-products replace conventional ingredients 
in concentrate of dairy goat diet?. Journal of Dairy Science 100, 4500-4512.

Romero-Huelva, M., and Molina-Alcaide, E. (2013). Nutrient utilization, ruminal fermentation, microbial nitrogen flow, microbial abundances, and methane emissions in goats fed diets including tomato and cucumber waste fruits. Journal of Animal Science 91, 914-923.

Romero-Huelva, M., Ramos-Morales, E., and Molina-Alcaide, E. (2012). Nutrient utilization, ruminal fermentation, microbial abundances, and milk yield and composition in dairy goats fed diets including tomato and cucumber waste fruits. Journal of Dairy Science 95, 6015-6026.

Sadeghi, H., Teimouri Ynsari, A., and Ansari-pirsarai, Z. (2009). Effects of different olive cake by products on dry matter intake, nutrient digestibility and performance of Zel sheep. International Journal of Agriculture and Biology 11, 39-43.

Salmeron, J., Hu, F. B., and Manson, J. E. (2001). Dietary fat intake and risk of type 2 diabetes in women. The American Journal of Clinical Nutrition 73, 1019-1026.

Sánchez-Zapata, E., Sayas-Barbera, E., Sendra, E., Perez-Alvarez, J.A., and FernandezLopez, J. (2014). Tomato and tomato byproducts. Human health benefits of lycopene and its application to meat products: a review. Critical Reviews in Food Science and Nutrition 54, 1032-1049.

Sansoucy, R., Alibes, X., Berge, P. H., Martilotti, F., Nefzaoui, A., and Zoiopoulos, P. (1985). Olive By-Products for Animal Feed. In "FAO Animal Production and Health Paper 43". FAO.

Sanzani, S. M., Schena, L., Nigro, F., Sergeeva, V., Ippolito, A., and Salerno, M. G. (2012). Abiotic diseases of olive. Journal of Plant Pathology 94, 469-491.

SAS Institute. (2017). SAS/STAT®Users Guide, Version 9.3. SAS Inst. Inc.

Sasikala-Appukuttan, A. K., Schingoethe, D. J., Hippen, A. R., Kalscheur, K. F., Karges, K., and Gibson, M. L. (2008). The feeding value of corn distillers solubles for lactating dairy cows. Journal of Dairy Science 91, 279-287.

Schingoethe, D. J., Kalscheur, K. F., Hippen, A. R., and Garcia, A. D. (2009). Invited review: The use of distillers products in dairy cattle diets. Journal of Dairy Science 92, 5802-5813.

Servili, M., Sordini, B., Esposto, S., Taticchi, A., Urbani, S., and Sebastiani, L. (2016). Metabolomics of olive fruit: a focus on the secondary metabolites. ed. Rugini, E. In 
"The Olive Genome, Compendium of Plants Genomes, vol. 2016". pp. 123-139. Springer International Publishing.

Servili, M., Esposto, S., Veneziani, G., Urbani, S., Taticchi, A., Di Maio, I., Selvaggini, R., Sordini, B., and Montedoro, G. (2011). Improvement of bioactive phenol content in virgin olive oil with an olive vegetation water concentrate produced by membrane treatment. Food Chemistry 124, 1308-1315.

Shingfield, K. J., Ahvenjärvi, S., Toivonen, V., Ärölä, A., Nurmela, K. V. V. P., Huhtanen, P., and Griinari, J. M. (2003). Effect of fish oil on biohydrogenation of fatty acids and milk fatty acid content in cows. Animal Science 77, 165-179.

Sinclair, W.B. (1984). The Biochemistry and Physiology of the Lemon and Other Citrus Fruits. Division of Agriculture and Natural Resources. University of California.

Singleton, V. L., and Rossi, J. A. (1965). Colorimetry of total phenolics with phosphomolybdic-phosphotungstic acids reagents. American Journal of Enology and Viticulture 16, 144-158.

Sniffen, C. J., O’Connor, J. D., Van Soest, P. J., Fox, D. G., and Russell, J. B. (1992). A net carbohydrate and protein system for evaluating cattle diets: II Carbohydrate and protein availability. Journal of Dairy Science 70, 3562-3577.

Talens, C., Arboleya, J. C., Castro-Giraldez, M., and Fito, P. J. (2017). Effect of microwave power coupled with hot air drying on process efficiency and physicochemical properties of a new dietary fibre ingredient obtained from orange peel. $L W T$ Food Science and Technology 77, 110-118.

Theriez, M., and Boule, G. (1970). Nutritive value of olive cake. Annales De Zootechnie 19, 143-148.

Thomas, J. W., Yu, Y., Middleton, T., and Stallings, C. Protein requirements for cattle: Symposium. Oklahoma, USA, ed. Oklahoma State Univ. 1982. In "Oklahoma State Univ. Publ. MP-109F”. pp. 81.

Tufarelli, V., Introna, M., Cazzato, E., Mazzei, D., and Laudadio, V. (2013). Suitability of partly destoned exhausted olive cake as byproduct feed ingredient for lamb production. Journal of Animal Science 91, 872-877.

Uribe, E., Lemus-Mondaca, R., Vega-Gálvez, A., López, L. A., Pereira, K., López, J., Ah-Hen, K., and Di Scala, K. (2013). Quality characterization of waste olive cake during hot air drying: nutritional aspects and antioxidant activity. Food and 
Bioprocess Technology 6, 1207-1217.

Valdez-Morales, M., Espinosa-Alonso, L. G., Espinoza-Torres, L. C., Delgado-Vargas, F., and Medina-Godoy, S. (2014). Phenolic content and antioxidant and antimutagenic activities in tomato peel, seeds, and byproducts. Journal of Agricultural and Food Chemistry 62, 5281-5289.

Valenti, B., Luciano, G., Pauselli, M., Mattioli, S., Biondi, L., Priolo, A., Natalello, A., Morbidini, L., and Lanza, M. (2018). Dried tomato pomace supplementation to reduce lamb concentrate intake: Effects on growth performance and meat quality. Meat Science 145, 63-70.

Van Soest, P. J. (1994). Nutritional Ecology of the Ruminant, 2nd ed. pp. 476. Cornell University Press.

Van Soest, P. J., Robertson, J. B., and Lewis, B. A. (1991). Methods for dietary fiber, neutral detergent fiber, and nonstarch polysaccharides in relation to animal nutrition. Journal of Dairy Science 74, 3583-3597.

Van Soest, P. J., and McQueen, R. W. (1973). The chemistry and estimation of fibre. Proceedings of the Nutrition Society 32, 123-130.

Van Soest, P. J. (1966). Nonnutritive residues: A system of analysis for the replacement of crude fiber. Journal of AOAC International 49, 546.

Van Soest, P. J. (1965). Use of detergents in analysis of fibrous feeds. III. Study of effects of heating and drying on yield of fiber and lignin in forages. Journal of AOAC International 48, 785.

Vanegas, J. L., Carro, M. D., Alvir, M. R., and González, J. (2017). Protection of sunflower seed and sunflower meal protein with malic acid and heat: effects on in vitro ruminal fermentation and methane production. Journal of the Science of Food and Agriculture 97, 350-356.

Vanegas, J. L., Arroyo, J. M., and González, J. (2016). Ruminal degradation of cell wall associated nitrogenous compounds of several 15N-labeled feeds. Journal of the Science of Food and Agriculture 96, 3991-3997.

Vargas-Bello-Pérez, E., Mustafa, A. F., and Sequin, P. (2008). Effects of feeding soybean silage on milk production, nutrient digestion, and ruminal fermentation of lactating dairy cows. Journal of Dairy Science 91, 229.

Vargas-Bello-Perez, E., Vera, R. R., Aguilar, C., Lira, R., Pena, I., and Fernandez, J. 
(2013). Feeding olive cake to ewes improves fatty acid profile of milk and cheese. Animal Feed Science and Technology 184, 94-99.

Vasta, V., and Luciano, G. (2011). The effects of dietary consumption of plants secondary compounds on small ruminants' products quality. Small Ruminant Research 101, 150-159.

Vasta, V., Makkar, H. P. S., Mele, M., and Priolo, A. (2009). Ruminal biohydrogenation as affected by tannins in vitro. British Journal of Nutrition 102, 82-92.

Vasta, V., Nudda, A., Cannas, A., Lanza, M., and Priolo, A. (2008). Alternative feed resources and their effects on the quality of meat and milk from small ruminants. Animal Feed Science and Technology 147, 223-246.

Ventura, M. R., Pieltain, M. C., and Castanon, J. I. R. (2009). Evaluation of tomato crop by-products as feed for goats. Animal Feed Science and Technology 154, 271-275.

Vera, R., Aguilar, C., Lira, R., Toro, P., Barrales, L., Pena, I., Squella, F., Pérez, P., Quenaya, J., Yutronic, H., and Briones, I. (2009). Feeding dry olive cake modifies subcutaneous fat composition in lambs, noting cake resistance to degradation and peroxidation. Chilean Journal of Agricultural Research 69, 548-559.

Vinha, A. F., Ferreres, F., Silva, B. M., Valentão, P., Gonçalves, A., Pereira, J. A., Oliveira, M. B., Seabra, R. M., and Andrade, P. B. (2005). Phenolic profiles of Portuguese olive fruits (Olea europaea L.): Influences of cultivar and geographical origin. Food Chemistry 89, 561-568.

Vlaeminck, B., Gervais, R., Rahman, M. M., Gadeyne, F., Gorniak, M., Doreau, M., and Fievez, V. (2015). Postruminal synthesis modifies the odd- and branched-chain fatty acid profile from the duodenum to milk. Journal of Dairy Science 98, 48294840 .

Vlyssides, A. G., Loizides, M., and Karlis, P. K. (2004). Integrated strategic approach for reusing olive oil extraction by-products. Journal of Cleaner Production 12, 603 611.

Vlyssides, A. G., Loizidou, M., Gimouhopoulos, K., and Zorpas, A. (1998). Olive oil processing wastes production and their characteristics in relation to olive oil extraction methods. Fresenius Environmental Bulletin 7, 308-313.

Wang, Q., Xiong, Z., Li, G., Zhao, X., Wu, H., and Ren, Y. (2016). Tomato peel powder as fat replacement in low-fat sausages: Formulations with mechanically 
crushed powder exhibit higher stability than those with airflow ultra-micro crushed powder. European Journal of Lipid Science and Technology 118, 175-184.

Weakley, D. C., Stern, M. D., and Satter, L. D. (1983). Factors affecting disappearance of feedstuffs from bags suspended in the rumen. Journal of Animal Science 56, 493507.

Weatherburn, M. W. (1967). Phenol-hypochlorite reaction for determination of ammonia. Analytical Chemistry 39, 971-974.

Webster, A. J. F. Metabolizable protein - the UK approach. Luxembourg, ed. Alderman, G., Jarrige, R. 1987. In "Feed Evaluation and Protein Requirement System for Ruminants". pp. 47-57. Commission of European Communities.

Weiss, W. P., Frobose, D. L., and Koch, M. E. (1997). Wet tomato pomace ensiled with corn plants for dairy cows. Journal of Dairy Science 80, 2896-2900.

Weiss, W. P., Erickson, D. O., Erickson, G. M., and Fisher, G. R. (1989). Barley distillers grains as a protein supplement for dairy cows. Journal of Dairy Science $\mathbf{7 2}$, 980.

Weiss, W. P., Conrad, H. R., and Shockey, W. L. (1986). Digestibility of nitrogen in heat damaged alfalfa. Journal of Dairy Science 69, 2658.

Wertz-Lutz, A., Zelinsky, R., and Held, J. (2007). Effects of increasing the energy density of a lactating ewe diet by replacing grass hay with soybean hulls and dried distillers grains with solubles. Animal Science Field Day Proceedings and Research Reports. 2007. [consulted 25/5/2019]. Available in: http://openprairie.sdstate.edu/cgi/viewcontent.cgi?article=1004\&context=sd_sheeprep ort_2006

Wilkinson, J. M. (2011). Re-defining efficiency of feed use by livestock. Animal 5, 1014-1022.

Williams, C. M. (2000). Dietary fatty acids and human health. Annales De Zootechnie 49, $165-180$.

Wing, J. M. (2003). Citrus Feedstuffs for Dairy Cattle. University of Florida, IFAS.

Wood, J. D., Enser, M., Fisher, A. V., Nute, G. R., Sheard, P. R., Richardson, R. I., Hughes, S. I., and Whittington, F. M. (2008). Fat deposition, fatty acid composition and meat quality: a review. Meat Science 78, 343-358.

Wood, J. D., Richardson, R. I., Nute, G. R., Fisher, A. V., Campo, M. M., Kasapidou, 
E., and Enser, M. (2003). Effects of fatty acids on meat quality: A review. Meat Science 66, 21-32.

Yáñez-Ruiz, D. R., Moumen, A., Martín-García, A. I., and Molina-Alcaide, E. (2004a). Comparative studies on microbial protein synthesis in the rumen of goats and sheep. Journal of Animal and Feed Sciences 1, 251-254.

Yáñez-Ruiz, D. R., Moumen, A., Martín-García, A. I., and Molina-Alcaide, E. (2004b). Ruminal fermentation and degradation patterns, protozoa population, and urinary purine derivatives excretion in goats and wethers fed diets based on two-stage olive cake: effect of PEG supply. Journal of Animal Science 82, 2023-2032.

Yansari, T. A., Sadeghi, H., Ansari-Pirsarai, Z., and Mohammad-Zadeh, H. (2007). Ruminal dry matter and nutrient degradability of different olive cake by-products after incubation in the rumen using nylon bag technique. International Journal of Agriculture and Biology 9, 439-442.

Yemm, E. W., and Willis, A. J. (1954). The estimation of carbohydrates in plant extracts by anthrone. Biochemical 157, 508-514.

Yilmaz, E., Aydeniz, B., Guneser, O., and Arsunar, E. (2015). Sensory and physicochemical properties of cold press-produced tomato (Lycopersicon esculentum L.) seed oils. Journal of the American Oil Chemists 'Society 92, 833-842.

Yu, Y., and Thomas, J. W. (1976). Estimation of the extent of heat damage in alfalfa hay silage by laboratory measurement. Journal of Animal Science 42, 766.

Yuangklang, C., Vasupen, K., Wongsuthavas, S., Bureenok, S., Panyakaew, P., Alhaidary, A., Mohamed, H. E., and Beynen, A. C. (2010). Effect of Replacement of Soybean meal by Dried Tomato Pomace on Rumen Fermentation and Nitrogen Metabolism in Beef Cattle. American Journal of Agricultural and Biological Sciences 5, 256-260.

Zhang, R. H., Mustafa, A. F., and Zhao, X. (2006). Effects of feeding oilseeds rich in linoleic and linolenic fatty acids to lactating ewes on cheese yield and on fatty acid composition of milk and cheese. Animal Feed Science and Technology 127, 220-233.

Zuorro, A., and Lavecchia, R. (2013). Optimization of enzyme-assisted lycopene extraction from tomato processing waste. Advanced Materials Research 800, 173-176. 


\section{Chapter IX. APPENDIX}




\section{IX.1. Influence of particle size of}

\section{crude olive cake on in vitro ruminal}

\section{fermentation and gas production}

\section{kinectics}

Marcos C. N., Chávez, S., De Blas., C., Molina-Alcaide, E., Ranilla, M. J., and Carro, M. D. (2019). Influence de la taille des particules des grignons d'olive sur la fermentation ruminal et la cinétique de production de gaz. In: Ruiz R., López-Francos A., López Marco L. (eds). Innovation for Sustainability in Sheep and Goats, 2nd Joint Seminar of the Subnetworks on Nutrition and on Production Systems of the FAOCIHEAM Network for Research and Development in Sheep and Goats. Vitoria-Gasteiz (Spain), 3-5 October 2017. Options Méditerranéennes: Series A (Mediterranean Seminars), no. 123. Available at: http://om.ciheam.org/option.php?IDOM=1034 
Abstract: By-products of olive oil industry can be used in ruminants feeding, but their nutritive value can be affected by the processing method. The aim of this research was to estimate in vitro the nutritive value of four samples of crude olive cake (COC) with different particle size obtained during the drying process from the same trommel at different stages of the screening procedure. Particles size was greater than $3 \mathrm{~mm}$ (COC3), $2 \mathrm{~mm}(\mathrm{COC} 2)$ and $1 \mathrm{~mm}(\mathrm{COC} 1)$ or smaller than $1 \mathrm{~mm}(\mathrm{COC} 0)$. Alfalfa hay and barley straw were included in the study for comparative purposes. Chemical composition was analysed in all samples. Gas production kinetics was determined in 120 -h in vitro incubations with sheep rumen fluid as inoculum, and fermentation parameters and in vitro dry matter digestibility (IVDMD) were analysed after $24 \mathrm{~h}$ of incubation. COC3 and COC0 samples had lower contents of neutral detergent fibre (NDF; 415 and $391 \mathrm{~g} / \mathrm{kg} \mathrm{DM}$ ), but greater crude protein (96.6 and $114 \mathrm{~g} / \mathrm{kg} \mathrm{DM}$ ) and ether extract (220 and $242 \mathrm{~g} / \mathrm{kg} \mathrm{DM}$ ) contents, than COC2 and COC3 (627 and 624; 42.4 and 48.7; 102 and $124 \mathrm{~g} / \mathrm{kg} \mathrm{DM}$, respectively). IVDMD of COC samples ranged from 39.4 to $58.7 \%$, and was lower than that for alfalfa hay $(67.5 \%)$ for all samples, but greater than that for barley straw (42.4\%) for COC0 and COC3 samples. COC3 and COC0 samples had greater $(\mathrm{P}<0.05)$ potential gas production $(103$ and $66.2 \mathrm{ml} / \mathrm{g} \mathrm{DM}$, respectively) and total volatile fatty acids production (608 and $600 \mu \mathrm{mol}$, respectively) than COC2 and COC1, but values were lower than those for alfalfa hay $(202 \mathrm{ml} / \mathrm{g} \mathrm{DM}$ and $1023 \mu \mathrm{mol}$, respectively) and barley straw (198 ml/g DM and $733 \mu \mathrm{mol})$. The results indicate that decreasing particle size to $<1 \mathrm{~mm}$ increased the fermentation potential of COC, but its nutritive value was still slightly lower than that of barley straw. The similar quality observed for COC3 and COC0 samples was attributed to the high sugar content of COC 3 samples.

Keywords: Olive cake - Particle size - Chemical composition - Gas production Ruminal fermentation.

IX.1.1. Introduction

Olive oil extraction generates several by-products that can be used in animal feeding, especially the cakes and pomaces obtained in the extraction process, but their characteristics and nutritive value depend markedly on the processing method (Heuzé et al., 2015). The main product is the "alperujo", which is stored in open ponds until processing, frequently over a period of several months. Alperujo is dried and olive 
stones are separated from the pulp by a process of screening. This process consists of placing the alperujo in a trommel (a cylinder of perforated metal, open at both ends and with a slight incline), that rotates classifying the material by their particle size (Savage et al., 2005). The screening for stones removal produces COC with different particle sizes, and may influence the nutritional quality of COC. The objective of this study was to analyse the influence of particle size of $\mathrm{COC}$ on their chemical composition, in vitro ruminal fermentation and gas production kinetics.

IX.1.2. Materials and methods

Four samples of crude olive cake (COC) obtained from the same trommel at different stages of the screening process were used in this study. Samples had different particle size: bigger than 3 (COC3), 2 (COC2) and $1 \mathrm{~mm}$ (COC1), or smaller than $1 \mathrm{~mm}$ (COC0). Chemical composition was analysed according to the AOAC (2005). Neutral detergent fibre (NDF), acid detergent fibre (ADF) and lignin analyses were carried out as described by Van Soest et al. (1991).

Substrates were fermented in vitro to determine gas production kinetics and ruminal fermentation parameters. One sample of alfalfa hay and barley straw were also incubated for comparative purposes. Samples (200 mg of dry matter (DM)) of each substrate were weighed into $60-\mathrm{mL}$ bottles. Ruminal fluid was obtained from four rumen-cannulated Lacaune sheep $(64.7 \pm 2.10 \mathrm{~kg}$ body weight $)$ fed grass hay and concentrate in 2:1 proportion twice daily. Sheep were managed according to the protocols approved by the Institutional Animal Care and Use Committee of the Technical University of Madrid and had free access to water over the trial. Ruminal contents of each sheep were obtained immediately before the morning feeding, strained through four layers of cheesecloth and mixed with the buffer solution of Goering and Van Soest (1970; no trypticase added) in a proportion 1:4 (vol/vol) at $39^{\circ} \mathrm{C}$ under continuous flushing with $\mathrm{CO}_{2}$. Bottles were prewarmed $\left(39^{\circ} \mathrm{C}\right)$ prior to the addition of $20 \mathrm{ml}$ of buffered rumen fluid, capped and incubated at $39{ }^{\circ} \mathrm{C}$. Two incubation runs were performed. In the first incubation run, gas production was measured at 3, 6, 9, 12 , 18, 24, 36, 48, 72, 96 and $120 \mathrm{~h}$ using a pressure transducer (Widereager Wide Range Pressure Meter, Sper Scientific LTD, Scottsdale, AZ, USA) and a calibrated syringe, and the gas produced at each measurement time was released. Bottles without sample (blanks) were incubated to correct for endogenous gas production. In the second run, 
bottles were incubated for $24 \mathrm{~h}$, gas production was measured as described before and a gas sample $(10 \mathrm{ml})$ was stored in a vacuum tube for $\mathrm{CH}_{4}$ analysis. Bottles were then uncapped and samples for volatile fatty acid (VFA) and $\mathrm{NH}_{3}-\mathrm{N}$ analyses were taken as described by Martínez et al. (2010). Procedures for $\mathrm{CH}_{4}$, VFA and $\mathrm{NH}_{3}-\mathrm{N}$ analyses have been also described by Martínez et al. (2010). The amount of OM apparently fermented (OMAF) in each bottle was estimated from VFA production as described by Demeyer (1991).

In vitro DM digestibility (IVDMD) was determined by weighting $300 \mathrm{mg}$ of substrate in polyester bags $(30 \mu \mathrm{m}$ pore size; Ankom Corp \#57, Ankom Technology Corp., Fairport, NY, USA) which were incubated with buffered ruminal fluid in an Ankom Daisy II incubator (Ankom Technology Corp, Fairport, NY, USA) at $39{ }^{\circ} \mathrm{C}$ under continuous rotation. After $24 \mathrm{~h}$, bags were washed with cold water, dried at $60{ }^{\circ} \mathrm{C}$ for $48 \mathrm{~h}$ and weighted to calculate the IVDMD. Three bags were used for each substrate.

Gas production data were fitted with time using the exponential model: gas $=\mathrm{A}$ $(1-\mathrm{e}-(-c(\mathrm{t}-L a g)))$, where $\mathrm{A}$ is the asymptotic gas production $(\mathrm{mL}), c$ is the fractional rate of gas production (h-1), Lag is the initial delay in the onset of gas production (h) and $\mathrm{t}$ is the gas measurement time. The parameters $\mathrm{A}, \mathrm{c}$ and lag were estimated by an iterative least squares procedure using the NLIN procedure of SAS (version 9.2; SAS Inst. Inc., Cary, NC, USA). The average gas production rate (AGPR; $\mathrm{mL}$ gas $/ \mathrm{h})$ was calculated as AGPR $=\mathrm{A} \mathrm{c} /[2(\ln 2+c$ Lag $)]$. Data were analysed as a mixed model using the PROC MIXED of SAS. The effect of substrate was considered fixed and that of the inoculum as random. Significance was declared at $\mathrm{P}<0.05$, and comparison of means was performed by the Tukey test.

IX.1.3. Results and discussion

Content of crude protein (CP), NDF, ADF, lignin and ether extract in COC samples ranged from 42.4 to 114,391 to 627,273 to 408,122 to150, and 102 to 242 $\mathrm{g} / \mathrm{kg} \mathrm{DM}$, respectively (Table 26). These values are in the range of those reported by others for COC samples from different sources (Molina-Alcaide and Yáñez-Ruiz, 2008; Molina-Alcaide et al., 2003), with the exception of EE content, which was greater in our samples. The high amount of CP bound to the ADF in the COC samples (11 to $43 \%$ of total $\mathrm{CP}$ ) indicated a low $\mathrm{N}$ availability, as previously reported for COC (Molina- 
Alcaide and Yáñez-Ruiz, 2008). The IVDMD of COC samples ranged from 39.4 to $58.7 \%$, and was lower than that for alfalfa hay (67.5\%) for all samples, but greater than that for barley straw (42.4\%) for COC0 and COC3 samples.

Table 26. Chemical composition ( $\mathrm{g} / \mathrm{Kg}$ dry matter) and in vitro dry matter digestibility (IVDMD) of crude olive cake (COC) samples with different particle size and two forages.

\begin{tabular}{cccccccc}
\hline & COC3 & COC2 & COC1 & COC0 & Alfalfa hay & Straw \\
\hline Crude protein (CP) & 96.6 & 42.4 & 48.7 & 114 & 194 & 55.6 \\
Neutral detergent fibre (NDF) & 415 & 627 & 624 & 391 & 394 & 697 \\
Acid detergent fibre (ADF) & 298 & 408 & 418 & 273 & 215 & 388 \\
Lignin & 122 & 148 & 163 & 150 & 45 & 38.8 \\
Crude protein bound to the ADF & 29.4 & 10.7 & 12.7 & 42.5 & 66.2 & 19.2 \\
Ether extract & 220 & 102 & 124 & 242 & 47.2 & 28.5 \\
IVDMD (\%) & 58.7 & 39.4 & 40.9 & 49.4 & 67.5 & 42.4 \\
\hline
\end{tabular}

As shown in Table 27, COC3 had the greatest $(\mathrm{P}<0.05)$ asymptotic gas production (A) and $\mathrm{COC} 2$ and $\mathrm{CO} 1$ had the lowest values. The higher gas production values observed in $\mathrm{COC} 3$ would indicate a more extensive fermentation, as cumulative gas production is directly related with the amount of organic matter fermented (Menke et al., 1979). In contrast, there were no differences $(\mathrm{P} \geq 0.146)$ among COC samples for $c$ and Lag parameters. COC3 also showed a greater value $(\mathrm{P}<0.05)$ of AGPR compared with the other samples. Cumulative gas production over the first $24 \mathrm{~h}$ of incubation was greater for $\mathrm{COC} 3$ and $\mathrm{COC} 0$ than that for barley straw, but $\mathrm{COC} 2$ and $\mathrm{COC} 1$ showed similar values to straw (Figure 4). Gas production for all COC samples was lower than that for alfalfa hay at all sampling times.

Table 27. Gas production parameters of crude olive cake (COC) samples with different particle size and two forages $(n=4)^{1}$.

\begin{tabular}{ccccc}
\hline Substrate $^{\mathbf{1}}$ & $\mathbf{A}$ & $\mathbf{c}$ & Lag & AGPR \\
\hline COC3 & $103^{\mathrm{c}}$ & 0.0558 & 0.4 & $3.98^{\mathrm{b}}$ \\
COC2 & $29.1^{\mathrm{a}}$ & 0.0801 & 2.08 & $1.37^{\mathrm{a}}$ \\
COC1 & $30.7^{\mathrm{a}}$ & 0.0813 & 1.76 & $1.54^{\mathrm{a}}$ \\
COC0 & $66.2^{\mathrm{b}}$ & 0.0531 & 1.21 & $2.35^{\mathrm{a}}$ \\
sem $^{2}$ & 2.14 & 0.01002 & 0.23 & 0.23
\end{tabular}



$\mathrm{P}=$
$<0.001$
0.146
0.242
$<0.001$

Forages

$\begin{array}{lllll}\text { Alfalfa hay } & 202 & 0.0442 & 1.82 & 5.73 \\ \text { Barley straw } & 198 & 0.0303 & 15.4 & 2.57\end{array}$

${ }^{\mathrm{a}-\mathrm{c}}$ Means in the same row with different superscript differ $(\mathrm{P}<0.05)$

${ }^{1}$ A: potential gas production; $c$ : fractional rate of gas production; Lag: time until the production of gas begins; AGPR: gas production rate until it has reached half of the A value

${ }^{2}$ sem: standard error of the mean

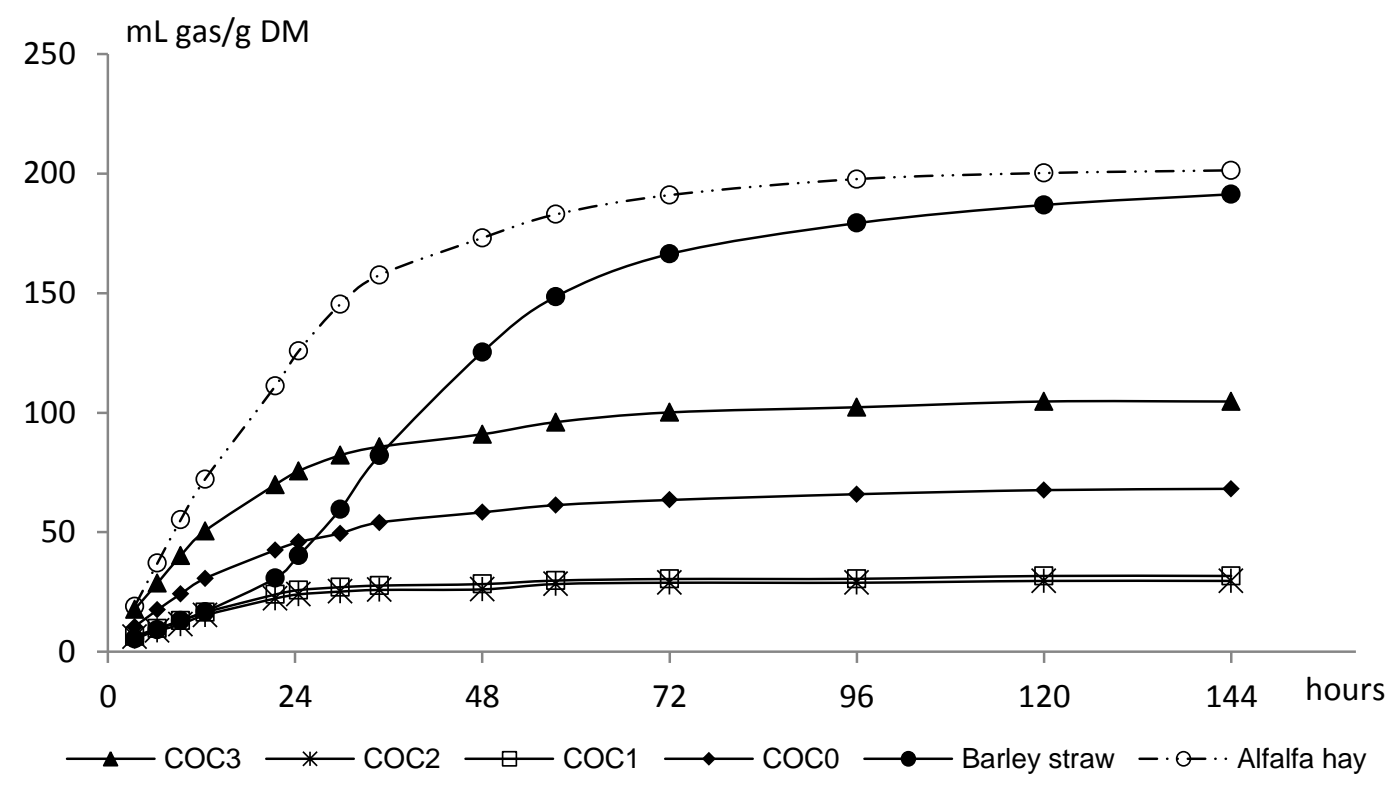

Figure 4. In vitro cumulative gas production of COC samples with different particle size and two forages. 
The results of the $24 \mathrm{~h}$ in vitro fermentations (Table 28) were in well agreement with those observed for gas production kinetics. Both $\mathrm{COC} 3$ and $\mathrm{COC} 0$ produced more $(\mathrm{P}<0.05)$ total VFA, acetate, propionate and $\mathrm{CH}_{4}$ than $\mathrm{COC} 2$ and $\mathrm{COC} 1$, resulting in greater $(\mathrm{P}<0.05)$ amount of OMAF. In contrast, there were no differences $(\mathrm{P}>0.05)$ among $\mathrm{COC}$ in $\mathrm{NH}_{3}$ concentrations, which may be due to the use of a $\mathrm{N}$-enriched buffer solution. The greater fermentation of $\mathrm{COCO}$ may be explained by its lower stone content, as stones are low fermentable. The high fermentation observed in COC3 may have been due to a high sugar content, as this sample contained small green-coloured balls which were identified as caramelized sugars (Bacha, personal communication). Both VFA and $\mathrm{CH}_{4}$ production were lower in all COC samples than in the two tested forages, indicating that COC samples were less fermented.

\section{IX.1.4. Conclusions}

Olive cake samples differing in particle size showed marked differences in chemical composition and in vitro ruminal fermentation parameters, with samples having more than $3 \mathrm{~mm}$ or less than $1 \mathrm{~mm}$ showing the highest fermentability. Crude olive cake could be used in ruminant diets replacing fibrous feeds with low nutritional value, but due to its high fat content olive cake would also contribute to increase the energy level of the diet. 
Table 28. In vitro fermentation parameters after $24 \mathrm{~h}$ incubation of crude olive cake (COC) samples with different particle size and two forages with buffered ruminal fluid from sheep $(n=4)^{1}$.

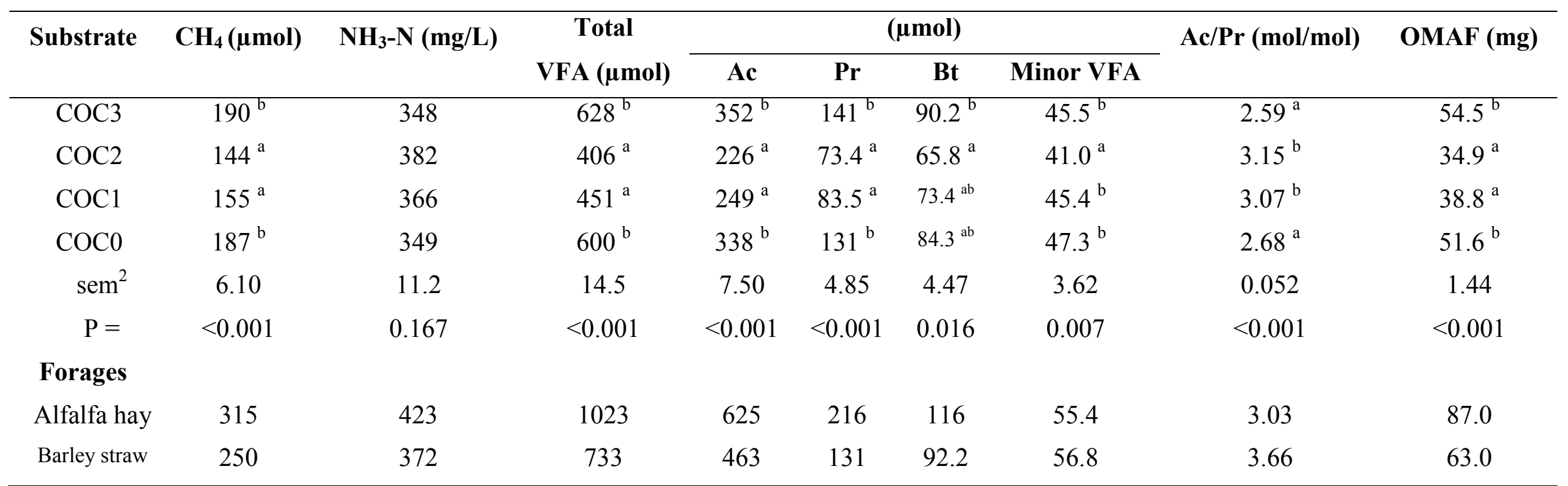

${ }^{\mathrm{a}-\mathrm{c}}$ Means in the same row with different superscript differ $(\mathrm{P}<0.05)$

${ }^{1}$ Minor VFA are calculated as the sum of isobutyrate, isovalerate, valerate and caproate. The amount of organic matter apparently fermented (OMAF) was calculated from VFA production as described by Demeyer (1991).

${ }^{2}$ sem: standard error of the mean 
References

Association of Official Analytical Chemists (AOAC). (2005). Official Methods of Analysis, 18th ed. AOAC International.

Demeyer, D. Quantitative aspects of microbial metabolism in the rumen and hindgut. Paris, France, ed. Jouany, J. P. 1991. In "Rumen Microbial Metabolism and Ruminant Digestion". pp. 217-237. INRA Editions.

Heuzé, V., Tran, G., Gomez-Cabrera, A., and Lebas, F. (2015). Olive oil cake and byProducts. In "Feedipedia, a Programme by INRA, CIRAD, AFZ and FAO". [consulted 11/02/2019]. Available in: https://www.feedipedia.org/node/32

Goering, M. K., and Van Soest, P. J. (1970). Forage Fiber Analysis (Apparatus, Reagents, Procedures and Some Applications). In "Agricultural Handbook; Agriculture Handbook No. 379”. Agricultural Research Services.

Martínez, M. E., Ranilla, M. J., Tejido, M. L., Ramos, S., and Carro, M. D. (2010). The effect of the diet fed to donor sheep on in vitro methane production and ruminal fermentation of diets of variable composition. Animal Feed Science and Technology 158 126-135.

Menke, K. H., Raab, L., Salewski, A., Steingass, H., Fritz, D., and Schneider W. (1979). The estimation of the digestibility and metabolizable energy content of ruminant feeding stuffs from the gas production when they are incubated with rumen liquor in vitro. The Journal of Agricultural Science 93, 217-222.

Molina-Alcaide, E., Yáñez-Ruiz, D. R., Moumen, A., and Martín-García A. I. (2003). Chemical composition and nitrogen availability of some olive by-products. Small Ruminant Research 49, 329-336.

Molina-Alcaide, E., and Yáñez-Ruiz, D. R. (2008). Potential use of olive by-products in ruminant feeding: a review. Animal Feed Science and Technology 147, 247-264.

Savage, G., Díaz, L., and Goldstein, N. (2005). A compost screening premier. In “BioCycle". pp. 55-59. J.G. Press Inc.

Van Soest, P. J., Robertson, J. B., and Lewis, B. A. (1991). Methods for dietary fiber, neutral detergent fiber and nonstarch polysaccharides in relation to animal nutrition. Journal of Dairy Science 74, 3583-3597. 


\section{IX.2. Effects of agro-industrial by- products supplementation on dairy}

\section{goats milk characteristics, nutrients}

\section{utilization, ruminal fermentation and}

\section{methane production}

Marcos C. N., Carro, M. D., Fernández-Yepes, J., Haro, A., Romero-Huelva, M., and Molina-Alcaide, E. (2019). Effects of including a mixture of agroindustrial by-products in the diet of dairy goats on nutrients utilization, ruminal fermentation, methane production and milk yield and composition. Journal of Dairy Science. (Under Review: R1 submitted after a "minor revision" decision).

ISI Journal Citation Reports Ranking 2018: Journal of Dairy Science was ranked 4 out of 61 Journals in the area of "Agriculture, Dairy \& Animal Science" 
INTERPRETIVE SUMMARY: Feeding agroindustrial by-products to ruminants can have multiple benefits, such as lowering feeding costs, reducing competition with human food, decreasing environmental impact associated with by-products disposal, and improving the quality of animal products. We evaluated the effect of replacing $44 \%$ of conventional feeds with corn distillers grains with solubles (DDGS; 18\%), dried citrus pulp (18\%) and exhausted olive cake (8\%) in a concentrate for dairy goats. Goats fed the by-products tended to produce more milk with more unsaturated fatty acids, and did not show any negative effect in either nutrient utilization or rumen fermentation.

Running head: Agroindustrial by-products in dairy goats feeding

Simple Summary: Effects of including a mixture of agroindustrial by-products in the diet of dairy goats on nutrients utilization, ruminal fermentation, methane production and milk yield and composition by Navarro et al. Feeding by-products to ruminants can contribute to sustain ruminant production by decreasing diet cost. Additionally it may reduce both competition with human food and environmental impact, and improve the quality of animal products. The effect of replacing $44 \%$ of conventional feeds with DDGS (18\%), DCP (18\%) and EOC (8\%) in a concentrate for dairy goats has been evaluated. Goats fed the diet including by-products tended to produce more milk with a healthier fatty acid profile, and did not show any negative effect in either nutrient utilization or rumen fermentation.

Abstract: The use of agroindustrial by-products, such as dried distillers grains with solubles (DDGS) and dried citrus pulp (DCP), has been widely investigated in dairy cows, but information on their effects in dairy goats is limited. The influence of olive cake (a by-product of olive oil production) feeding to dairy goats has been assessed in some studies, but exhausted olive cake (EOC) has been much less investigated. Twelve Murciano-Granadina goats were used in a cross-over design trial with two periods to assess the effects of including agroindustrial by-products on nutrient digestibility, ruminal fermentation, methane production, urinary excretion of purine derivatives and milk yield and composition. In each period, 6 goats received daily a control diet composed of $1 \mathrm{~kg}$ of alfalfa hay and $1 \mathrm{~kg}$ of high-cereal concentrate and other 6 goats received a diet (BYP) composed of $1 \mathrm{~kg}$ of alfalfa hay and $1 \mathrm{~kg}$ of a concentrate including corn DDGS, DCP and EOC in proportions of 180,180 and $80 \mathrm{~g} / \mathrm{kg}$ concentrate (as fed basis), respectively. Diet had no effect on total DM intake, but 
intake of alfalfa hay, $\mathrm{CP}$ and fat was greater $(\mathrm{P} \leq 0.042)$ for the BYP than for control group. There were no differences between diets in nutrients apparent digestibility, with the exception of fat which was greater $(\mathrm{P}=0.002)$ for BYP compared with control diet. Although fecal $\mathrm{N}$ tended to be greater $(\mathrm{P}=0.063)$ for BYP-diet, there were no differences in $\mathrm{N}$ utilization. Compared to control, milk yield tended to be greater $(\mathrm{P}=$ 0.056) and daily production of milk CP, fat, whey protein and TS, as well as milk gross energy, were greater $(\mathrm{P} \leq 0.031)$ for BYP diet. Diet BYP changed milk fatty acid $(\mathrm{FA})$ profile, as the concentration of $\mathrm{C} 12: 0, \mathrm{C} 14: 0$ and $\mathrm{C} 16: 0 \mathrm{FA}$ was or tended to be lower $(\mathrm{P} \leq 0.080)$ and that of polyunsaturated FA was greater $(\mathrm{P}=0.001)$ in the milk of BYPfed goats compared with those fed the control diet. Diet had no effect on ruminal parameters ( $\mathrm{pH}, \mathrm{VFA}$ and $\mathrm{NH}_{3}-\mathrm{N}$ concentrations) and methane emissions, but urinary excretion of total purine derivatives tended to be lower $(\mathrm{P}=0.070)$ in BYP-fed goats than in those fed the control diet. A mixture of corn DDGS (180 g), DCP (180 g) and EOC ( $80 \mathrm{~g}$ ) could replace $44 \%$ of cereal grains and protein feeds in the concentrate for dairy goats without compromising nutrient utilization, ruminal fermentation or milk yield, and led to a more unsaturated FA profile in milk.

Key words: dairy goats, DDGS, citrus pulp, exhausted olive cake, milk, fatty acids

IX.2.1. Introduction

The use of agroindustrial by-products in animal feeding, particularly in ruminants, is continuously increasing worldwide as it may reduce feeding costs and, other reasons that are equally or even more important to support the growing interest in their use in ruminants feeding. Many by-products are not potentially edible by humans, and therefore they do not compete with human food (Bakshi et al., 2016). Some byproducts have high pollution potential, and their inclusion in animal diets can contribute to reduce the environmental problems associated with their accumulation, concurrently contributing to sustainability of livestock production and reducing the carbon footprint of animal products (del Prado et al., 2013). By-products can also contain bioactive compounds that may improve not only animal health and quality of animal products, but also reduce methane emissions and contribute to decrease the environmental impact of livestock production (Romero-Huelva et al., 2012).

Dried distillers grains with solubles (DDGS) are by-products of the ethanol industry. Whereas there is a lot of information on the effects of DDGS in dairy cows 
feeding, to our best knowledge only Cais-Sokolińska et al. $(2015,2019)$ have evaluated their effect in dairy goats focusing on milk fatty acid (FA) profile, basic milk composition and cytological quality (SCC count) and both fermentation process and aroma profile of the resulting kefir, and no information on DDGS effects on the yield of goat's milk is available. Citrus pulp is the main by-product of citrus industry that can be fed fresh, ensiled or dried. Citrus pulp is used as a source of dietary energy, usually as cereal grains replacer. In both dairy cows and sheep, the inclusion of dry citrus pulp (DCP) in the diet up to $30 \%$ has been reported to have no negative effect on milk yield, fat content and flavor in some studies (reviewed by Bampidis and Robinson, 2006), but in others inclusion of DCP in diet increased milk yield and fat concentration. In dairy goats, López et al. (2014) observed that totally replacing the dietary corn with DCP had no effect on milk yield but increased milk fat concentration and Ibáñez et al. (2016) observed that dairy goats had greater fat mobilization when DCP completely replaced barley in the diet, although milk yield was not affected.

Olive oil extraction generates a wet solid-waste called "alperujo" that is stored in open-air ponds before being destoned and dried, in a process that generates a by-product called olive cake. Olive cake can be used in animal feeding or be subjected to a chemical extraction (using hexane or other authorized food-grade solvents) to obtain pomace olive oil, generating exhausted olive cake (EOC) as by-product (Marcos et al., 2019). This by-product is a fibrous material with low nutritive value, but rich in polyphenols (Marcos et al., 2019; Molina-Alcaide and Yáñez-Ruiz, 2008) and therefore it might modify ruminal fermentation and improve milk quality. The objective of this study was therefore to assess the effects of replacing conventional ingredients of a concentrate for dairy goats with a mixture of DDGS, DCP and EOC on feed intake and nutrient digestibility, milk yield and composition, urinary excretion of purine derivatives, and methane emissions.

IX.2.2. Materials and methods

Animals used in this trial were cared and handled in accordance with the Spanish guidelines for experimental animal protection, and all experimental procedures were approved by the Ethic Committee for Animal Experimentation of the Spanish Research Council and the Junta de Andalucía (approval number 29/08/2016/145).

IX.2.2.1. Animals and feeding 
Twelve Murciano-Granadina dairy goats producing $1837 \pm 146.7 \mathrm{~g}$ milk/d, with $51.5 \pm 1.83 \mathrm{~kg}$ of BW, and 12.8 \pm 1.17 DIM were divided into 2 homogeneous groups based on BW and milk yield at the beginning of the experiment. Goats were placed in individual boxes with free access to fresh water, and each group was randomly assigned to one of the two experimental diets: a control diet and a diet containing agroindustrial by-products (BYP). The control diet was based on alfalfa hay and a high-cereal concentrate in a 50:50 ratio. The BYP diet was also based on a 50:50 ratio alfalfa hay and concentrate, in which $44 \%$ of conventional ingredients (corn, barley, soybean meal, palmiste meal and wheat bran) was replaced with a mixture of 180, 180 and $80 \mathrm{~g}$ of corn DDGS, DCP and EOC per $\mathrm{kg}$ concentrate, respectively (fresh matter basis). The ingredients of both concentrates, and chemical composition and fatty acid (FA) profile of feeds are shown in Table 29. The diets were formulated to meet the $\mathrm{N}$ and energy requirements of Murciano-Granadina goats producing daily $2 \mathrm{~kg}$ of milk (Aguilera et al., 1990; Prieto et al., 1990), and were supplied twice a day at 09:00 and 16:00 over the trial. 
Table 29. Ingredient and chemical composition of experimental concentrates and potential use as human food of concentrate ingredients.

\begin{tabular}{|c|c|c|}
\hline \multirow[t]{2}{*}{ Item } & \multicolumn{2}{|c|}{ Concentrate } \\
\hline & Control & BYP \\
\hline \multicolumn{3}{|l|}{ Ingredients, $\mathrm{g} / \mathrm{kg}$ as fed } \\
\hline Corn & 330 & 268 \\
\hline Barley & 200 & - \\
\hline Wheat & 100 & 100 \\
\hline Soybean meal & 122 & 102 \\
\hline Palm meal & 88 & - \\
\hline Colza meal & 25 & 25 \\
\hline Weat bran & 100 & 30 \\
\hline Corn DDGS & - & 180 \\
\hline Dry citrus pulp & - & 180 \\
\hline Exhausted olive cake & - & 80 \\
\hline Calcium soap & 12.0 & 12.0 \\
\hline $\mathrm{CaCO}_{3}$ & 10.0 & 10.0 \\
\hline $\mathrm{NaHCO}_{3}$ & 8.0 & 8.0 \\
\hline $\mathrm{NaCl}$ & 3.0 & 3.0 \\
\hline Vitamin-mineral mixture $^{2}$ & 2.0 & 2.0 \\
\hline \multicolumn{3}{|c|}{ Chemical composition, $\mathrm{g} / \mathrm{kg}$ as fed basis } \\
\hline $\mathrm{DM}$ & 894 & 883 \\
\hline $\mathrm{OM}$ & 843 & 824 \\
\hline $\mathrm{CP}$ & 160 & 174 \\
\hline NDF & 205 & 208 \\
\hline $\mathrm{ADF}$ & 75.9 & 85.7 \\
\hline Lignin & 17.4 & 23.4 \\
\hline Ether extract & 28.2 & 47.0 \\
\hline Total soluble polyphenols & 1.95 & 6.05 \\
\hline \multicolumn{3}{|c|}{ Fatty acids, $\mathrm{g} / 100 \mathrm{~g}$ total fatty acids } \\
\hline $\mathrm{C} 12: 0$ & 7.01 & 0.282 \\
\hline $\mathrm{C} 14: 0$ & 2.78 & 0.371 \\
\hline C14:1 cis -9 & $\mathrm{ND}^{1}$ & 0.001 \\
\hline $\mathrm{C} 16: 0$ & 21.6 & 20.6 \\
\hline C16:1 cis-9 & 0.169 & 0.001 \\
\hline C18:0 & 2.78 & 2.76 \\
\hline C18:1 trans -9 & 0.077 & 0.004 \\
\hline C18:1 trans -11 & 0.080 & 0.002 \\
\hline C18:1 cis -9 & 26.6 & 34.5 \\
\hline C18:1 cis-11 & 0.828 & 0.875 \\
\hline C18:2 trans -9, trans -12 & 0.004 & 0.009 \\
\hline $\mathrm{C} 18: 2$ cis -9, cis -12 & 34.1 & 36.7 \\
\hline C20:0 & 0.343 & 0.427 \\
\hline Potential use of ingredients as & 64.4 & 38.7 \\
\hline
\end{tabular}

${ }^{\mathrm{T}} \mathrm{ND}$ : not detected.

${ }^{2}$ Contained (per kg): 40 mg Se; 250 mg I; $80 \mathrm{mg} \mathrm{Co} ; 3,000 \mathrm{mg} \mathrm{Cu}$; 6,000 mg Fe; $23.4 \mathrm{~g}$ Zn; 29 g Mn; 60 g S; 60 g Mg; 2,000,000 IU vitamin A; 400,000 IU vitamin D3; 2 g vitamin E; $10 \mathrm{~g}$ nicotinic acid; $20.3 \mathrm{~g}$ choline (Nacoop S.A., Madrid, Spain).

${ }^{3}$ Calculated according to Wilkinson (2011) 
IX.2.2.2. Experimental procedure and measurements

The experiment was conducted as a cross-over design with 2 periods of 37 days each, comprising $21 \mathrm{~d}$ of adaptation to diets, and $16 \mathrm{~d}$ for measurements and sampling. Over the trial, animals were milked once a day in the morning in a $1 \times 10$ stall milking parlour (DeLaval, Madrid, Spain), and were weighted at the beginning and end of each experimental period. On d 22 of each experimental period, animals were moved to individual metabolism crates and after 3-d of adaptation, total feces and urine voided by each animal were quantitatively collected for $5 \mathrm{~d}$. Urine was collected into buckets containing $10 \% \mathrm{HCl}$ ( $\mathrm{vol} / \mathrm{vol}$ ) to keep the $\mathrm{pH}$ below 3 and avoid $\mathrm{N}$ losses. Aliquots $(10 \%)$ of urine were taken daily for density measurement, and immediately frozen until analyses of $\mathrm{N}$ content, energy and purine derivative (PD) and creatinine concentrations. Samples $(20 \%)$ of total fecal output were collected each day for digestibility determination and stored at $-20^{\circ} \mathrm{C}$ until chemical analyses. Samples of feces and urine were pooled for each goat to form composite samples.

On d 30 goats were moved to floor pens, and on d 31 approximately $20 \mathrm{~mL}$ of ruminal fluid was collected from each animal before feeding using a stomach tube attached to a vacuum pump. The fluid was strained through 4 layers of cheesecloth, the $\mathrm{pH}$ was immediately measured, and $3 \mathrm{ml}$ of ruminal fluid were mixed with $3 \mathrm{ml} 0.5 \mathrm{M}$ $\mathrm{HCl}$ and stored frozen until $\mathrm{NH}_{3}-\mathrm{N}$ and VFA analyses. From d 32 to 37, 4 goats from each dietary treatment were sequentially placed in 4 individual open circuit respiration chambers ( 1 goat per chamber; $2 \mathrm{~d}$ of measurement) to measure individual methane emissions as described by Romero-Huelva and Molina-Alcaide (2013). Short methane measurement interruptions (10 min) occurred daily at 09:00 h for diet supply, milking, and chamber floor cleaning, but they had little effect on daily methane emissions as the corresponding exhaust duct was not sampled during this period. Fluxes were determined twice per day and averaged to calculate the 24-h emissions.

Individual feed and water intake were measured over the trial, but only values measured during the sampling period were used for the statistical analysis. During the sampling period, alfalfa hay and concentrate refusals from each animal were weighted daily, pooled, and stored at $-20{ }^{\circ} \mathrm{C}$ until analyses. Each day of the sampling period, milk yield was recorded using a $0.1 \mathrm{~g}$ precision balance, milk density was measured, and aliquots were stored at $-30{ }^{\circ} \mathrm{C}$ without preservatives for chemical analyses. 


\section{IX.2.2.3. Chemical analyses}

Dry matter (method 934.01), ash (method 942.05) and ether extract (method 920.39) content in samples of diet ingredients and refusals and feces were analyzed according to AOAC (2005). Total soluble polyphenols in feeds were analyzed by the Folin-Ciocalteu assay as described by Singleton et al. (1965). The N content of diet ingredients, refusals, and of feces and urine was determined according to the Dumas method using a TruSpec CN equipment (Leco Corp. St. Joseph, MI, USA). The analyses of NDF in diet ingredients and refusals were carried out according to Van Soest et al. (1991) using an Ankom 220 Fiber Analyzer unit (Ankom Technology Corp., Macedon, NY, USA), whereas ADF and acid detergent lignin were determined as described by Robertson and Van Soest (1981), and all results were expressed exclusive of residual ash. Energy content of diet ingredients, refusals, and of feces and urine was determined by using an adiabatic calorimeter (model 1356, Parr Instruments Co., Moline, IL).

The analyses of VFA and $\mathrm{NH}_{3}-\mathrm{N}$ concentrations in ruminal fluid were performed by gas chromatography and a colorimetric method, respectively, as described by Romero-Huelva and Molina-Alcaide (2013). Total solids in milk were determined by lyophilization of milk samples, and total $\mathrm{N}$ content was analyzed by the Dumas method. Non protein-N was analyzed in samples of milk filtrates after precipitation with $12 \%$ (wt/vol) trichloroacetic acid solution. Non casein-N was determined in milk filtrates after precipitation with $10 \%$ (wt/vol) acetic acid at a $\mathrm{pH}$ of 4.1 (Recio et al., 1997). Values of $\mathrm{N}$ in milk were converted to the corresponding protein by multiplying by 6.38. The milk fat content was measured following the Gerber method (Pearson, 1976).

Extraction of total FA in samples of alfalfa hay and concentrates was performed following the procedure of Folch et al. (1957), and the FA were methylated according to Kramer and Zhou (2001), with slight modifications, as a double methylation was carried out, using first $\mathrm{NaOH} /$ methanol, at $50{ }^{\circ} \mathrm{C}$ for $15 \mathrm{~min}$, followed by $\mathrm{HCl} / \mathrm{methanol}$ at 50 ${ }^{\circ} \mathrm{C}$ for $1 \mathrm{~h}$ to obtain the FA methyl esters (FAME). For milk FA composition analysis, FA were extracted and transesterified to FAME as described by Abecia et al. (2012). The FAME were separated and quantified using a gas chromatograph (Model Focus GC, Thermo Scientific, Milan, Italy) equipped with a flame-ionization detector and a 100-m fused silica capillary column $(0.25 \mathrm{~mm}$ i.d., $0.2-\mu \mathrm{m}$ film thickness; SP-Supelco, 
Bellefonte, PA) and helium as the carrier gas. Total FAME profile in a $1-\mu \mathrm{L}$ sample volume at a split ratio of 1:50 was determined using a temperature gradient program (Shingfield et al., 2003). Nonadecanoic acid (C19:0; Sigma-Aldrich-N5252) was used as an internal standard, and FAME peaks were identified by comparing their retention times with those of standards (47885 U and O5632: Sigma Aldrich, Madrid, Spain; 901093, Larodan Fine Chemicals, Stockholm, Sweden). Results are expressed as percentage of total FAME identified.

Methane concentrations were measured continuously in the air stream in each duct using a gas analyzer ADC MGA3000 (Spurling Works, Herts, UK) as detailed by Romero-Huelva et al. (2017). The concentration of creatinine and purine derivatives (PD; allantoine, uric acid, xanthine and hipoxanthine) in urine were determined by HPLC following the method described by Balcells et al. (1992) and the equipment detailed by Romero-Huelva et al. (2017).

\section{IX.2.2.4. Calculations and statistical analyses}

Nitrogen and energy balances were calculated as the difference between the amount of $\mathrm{N}$ and energy ingested and that lost in urine, feces and milk, and the energy lost as $\mathrm{CH}_{4}\left(0.890 \mathrm{MJ} / \mathrm{mol}\right.$ of $\mathrm{CH}_{4}$; Newbold et al., 2007). Milk protein-N content was calculated as the difference between total and non-protein $\mathrm{N}$ in milk, whereas the casein-N concentration in milk was calculated as the difference between total $\mathrm{N}$ and non casein-N. The amount of whey-N in milk was calculated as the difference between milk protein and casein-N. Milk lactose was calculated as the difference between the amount of total solids and that of protein, fat, and total ash in milk.

Data were analyzed as a mixed model using the PROC MIXED of SAS (SAS Institute Inc., Cary, NC), in which the effects of diet, period and their interaction were considered fixed and that of goat was considered random. Effects were declared significant at $\mathrm{P}<0.05$, and $\mathrm{P}$-values between 0.05 and 0.10 were considered as a trend.

IX.2.3. Results and discussion

IX.2.3.1. By-products and concentrates composition

Corn DDGS, DCP and EOC contained (as fed basis) 900, 897 and 823 g DM; 847, 840 and $741 \mathrm{~g}$ of OM; 264, 48.6 and $74.8 \mathrm{~g}$ of CP; 371, 179 and $464 \mathrm{~g}$ of NDF, and 98.1, 32.8 and $29.1 \mathrm{~g}$ of EE per $\mathrm{kg}$, respectively. Alfalfa hay contained (as fed basis) 
935, 807, 159, 447, 321, 74.7 and $12.8 \mathrm{~g}$ of DM, OM, CP, NDF, ADF, lignin and EE per $\mathrm{kg}$, respectively. The composition of by-products was in the range of previously published values for corn DDGS (NRC, 2001), DCP (NRC, 2001), and EOC (Marcos et al., 2019; Molina-Alcaide and Yañez-Ruiz, 2008). Both control and BYP concentrates were formulated to have similar CP and NDF contents, although BYP concentrate resulted in slightly greater $\mathrm{CP}$ content compared to control one. In addition, EE content was greater in BYP concentrate due to the high EE concentration in DDGS. The greater content in total soluble polyphenols of BYP compared with the control concentrate was attributed to the inclusion of DCP and EOC, which have greater polyphenols content (17.1 and $24.2 \mathrm{~g} / \mathrm{kg}$ in our study) than other conventional feeds used in ruminant diets (Marcos et al., 2019).

Compared with control, BYP concentrate had greater content of oleic (C18:1 cis-9) and linoleic (C18:2 cis-9, cis-12) acids and lower content of lauric (C12:0), myristic (C14:0) and palmitic (C16:0), acids, which is in agreement with previous results indicating that the inclusion of olive cake in the diet usually increases the amount of oleic acid (Luciano et al., 2013; Molina-Alcaide et al., 2010). Furthermore, about $80 \%$ of FA in DDGS are unsaturated (Pecka-Kielb et al., 2017), and the FA in citrus pulp are mainly oleic, linoleic, linolenic (C18:3), palmitic and stearic acids (C18:0) (Bampidis and Robinson, 2006), which might have contributed to the differences observed in FA profile of the two concentrates. The most abundant FA in alfalfa hay were palmitic, linoleic and linolenic $(24.7,21.9$ and $34.6 \%$ of total FA, respectively), which is in agreement with previous results (Romero-Huelva et al., 2017; Molina-Alcaide et al., 2010).

The proportion of each by-product in the diet was selected from in vitro studies by our group (unpublished results) and from previously in vivo published studies (Ibáñez et al., 2016; Molina-Alcaide et al., 2010; Molina-Alcaide and Yañez-Rúiz, 2008; Bampidis and Robinson, 2006). According to Wilkinson (2011), the estimated human edible proportion of ingredients in the concentrate was 25.7 percentage units lower in BYP than in control concentrate (64.4 vs. 38.7\%, respectively; Table 29), reflecting a lower use of human-edible foods for BYP diet. 
IX.2.3.2. Intake, apparent digestibility of nutrients, and energy and nitrogen balance

As shown in Table 30, there were no differences between groups in total DM, concentrate DM and water intake ( $\mathrm{P} \geq 0.17)$, but BYP-fed goats consumed more DM alfalfa hay $(\mathrm{P}=0.04)$ than those fed the control diet. An increase in alfalfa hay was also observed by Romero-Huelva et al. (2017) when dairy goats were fed a concentrate including by-products (tomato fruits, citrus pulp, brewer's grain and brewer's yeast) compared with those fed a high-cereal concentrate. Although in our study both concentrates had the same NDF concentration (Table 29), the NDF of DDGS and DCP is rapidly degraded in the rumen and might have a lower effectiveness in stimulating rumination, leading to a greater alfalfa hay intake to supply physically effective fiber. Intake of $\mathrm{CP}$ and fat in goats fed the BYP diet was greater $(\mathrm{P}=0.003$ and $<0.001$, respectively) than that in control-fed goats, which is consistent with the greater $\mathrm{CP}$ and fat content of BYP diet.

Table 30. Average values of feed and water intake and apparent digestibility of nutrients in dairy goats fed the experimental diets.

\begin{tabular}{lcccc}
\hline \multirow{2}{*}{ Item } & \multicolumn{2}{c}{ Diet $^{1}$} & \multirow{2}{*}{ SEM } & P-value \\
\cline { 2 - 3 } & Control & BYP & & \\
\hline Intake, g/d & & & & \\
Total DM & 1591 & 1637 & 21.3 & 0.17 \\
Alfalfa hay & 710 & 770 & 17.6 & 0.042 \\
Concentrate & 880 & 883 & 9.3 & 0.83 \\
OM & 1482 & 1508 & 19.0 & 0.37 \\
CP & 285 & 311 & 4.6 & 0.003 \\
EE & 38.5 & 58.4 & 0.50 & $<0.001$ \\
NDF & 553 & 577 & 9.8 & 0.12 \\
ADF & 330 & 353 & 7.5 & 0.07 \\
Water, L/d & 4.99 & 5.18 & 0.29 & 0.65 \\
Apparent digestibility, g/g & & & & \\
MO & 0.757 & 0.746 & 0.0067 & 0.27 \\
CP & 0.753 & 0.746 & 0.0066 & 0.48 \\
EE & 0.795 & 0.832 & 0.0059 & 0.002 \\
NDF & 0.553 & 0.572 & 0.0109 & 0.26 \\
ADF & 0.522 & 0.555 & 0.0145 & 0.15 \\
\hline
\end{tabular}

${ }^{1}$ Control: 40:60 alfalfa hay:high-cereal concentrate; BYP: 40:60 alfalfa hay:concentrate containing by-products 
There were no differences $(\mathrm{P} \geq 0.15)$ between diets in the nutrients apparent digestibility, with the exception of fat digestibility. The greater $(P=0.002)$ fat digestibility in BYP-fed compared with control-fed goats could be due to differences in the FA profile of the diets, as DDGS fat has been reported to be highly digestible (Kurokawa et al., 2012).

As there were no differences between diets in $\mathrm{CP}$ digestibility, the greater $\mathrm{N}$ fecal excretion in BYP-fed goats was expected due to their greater N intake (Table 31). There were no differences between diets in urine $\mathrm{N}$ excretion, but milk total $\mathrm{N}$, milk protein $\mathrm{N}$, and $\mathrm{N}$ retained in the body (calculated as the difference between $\mathrm{N}$ intake and $\mathrm{N}$ excreted in feces and urine) tended to be greater $(\mathrm{P} \leq 0.07)$ in goats fed the BYP diet compared with the control one. In contrast, total $\mathrm{N}$ retained (calculated as the difference between $\mathrm{N}$ intake and $\mathrm{N}$ excreted in feces, urine and milk) was not affected $(\mathrm{P}=0.12)$ by the diet. Values for fecal N, urinary $\mathrm{N}, \mathrm{N}$ retained in the body, and total retained $\mathrm{N}$ in the present study were greater than those reported by Romero-Huelva et al. (2017) for Murciano-Granadina goats fed a control diet or a diet in which the concentrate included by-products (averaged values $0.477,0.765,1.16$ and $0.706 \mathrm{~g} / \mathrm{kg} \mathrm{BW}^{0.75}$, respectively). In another study by the same group (Romero-Huelva et al., 2012), values for fecal $\mathrm{N}$ and urinary $\mathrm{N}$ measured in Murciano-Granadina goats fed diets containing different byproducts (averaged values 0.733 and $1.39 \mathrm{~g} / \mathrm{kg} \mathrm{BW}^{0.75}$, respectively) were similar to those observed in our study, but the amount of $\mathrm{N}$ retained in the body and total $\mathrm{N}$ retained were greater (1.0 and $0.551 \mathrm{~g} / \mathrm{kg} \mathrm{BW}^{0.75}$, respectively). The lower values observed in our study would indicate an inefficient use of dietary $\mathrm{N}$, possibly caused by an excess of RDP, as indicated by the high excretion of $\mathrm{N}$ in urine that was 52.8 and $46.1 \%$ of total $\mathrm{N}$ intake for control and BYP diets, respectively. The CP content used in the present study was chosen to be representative of those used in the practice in the feeding of high-producing dairy goats, although lower CP levels were used in the previously cited studies. In addition, the different lactation stage of the animals in the different trials (middle lactation in the study of Romero-Huelva et al. $(2017,2012)$ and early lactation in the present one) could help to explain the observed differences.

The lack of differences $(\mathrm{P} \geq 0.48)$ between diets in any parameter of $\mathrm{N}$ utilization indicates that the inclusion of DDGS, DCP and EOC in the concentrate did not affect negatively the efficiency of $\mathrm{N}$ utilization. In addition, the BYP diet tended (P $=0.10)$ to increase the $\mathrm{N}$ retained body/digestible $\mathrm{N}$ ratio, which is in agreement with 
the numerically lower weight loss observed in BYP-fed goats (Table 31).

There were no differences $(\mathrm{P} \geq 0.11)$ between diets in gross energy intake, fecal and urinary energy losses, and the intake of digestible and ME energy (Table 31). In contrast, milk energy, either expressed as $\mathrm{MJ} / \mathrm{kg}$ of $\mathrm{BW}^{0.75}$ or as a proportion of both digestible and $\mathrm{ME}$ energy intake, was greater $(\mathrm{P} \leq 0.04)$ in $\mathrm{BYP}-\mathrm{fed}$ goats compared with those fed the control diet, suggesting an improvement of the efficiency of energy utilisation in BYP-fed goats.

\section{IX.2.3.3. Milk yield and composition}

Milk yield tended to be greater $(\mathrm{P}=0.06)$ and the daily production of milk fat, protein, whey protein and TS, as well as milk gross energy, were greater $(\mathrm{P} \leq 0.03)$ for goats fed the BYP diet compared with those fed the control diet. In agreement with our results, the inclusion of $600 \mathrm{~g}$ of DCP per kg in the diet of dairy goats has been reported to have no negative effect on milk yield and to increase the production of milk fat (Ibáñez et al., 2016; López et al., 2014). Milk yield response to DDGS inclusion in the diet has also been positive in dairy cows (Hollmann et al., 2011), and an increase in milk protein and lactose yield has been reported in several studies (Janicek et al., 2008; Anderson et al., 2006; Kleinschmit et al., 2006). In contrast, no effect on milk yield was observed in sheep fed 20\% of DDGS (Pecka-Kielb et al., 2017), and even a reduction in milk protein, fat and TS has been observed by Radunz et al. (2011). The results on the influence of olive cake feeding on milk yield and composition are also controversial. Chiofalo et al. (2004) reported an increase in milk yield when including $200 \mathrm{~g} / \mathrm{kg}$ of olive cake in the diet of dairy ewes, but Vargas-Bello-Pérez et al. (2013) observed no effect on milk yield by including up to $250 \mathrm{~g} / \mathrm{kg}$ of olive cake in dairy ewes, and Molina-Alcaide et al. (2010) found a decrease in milk yield in goats which received a diet with $120 \mathrm{~g} / \mathrm{kg}$ of olive cake. The variable composition of olive cake, especially in their sugars and fat content (Marcos et al., 2019), can explain these contrasting results. 
Table 31. Average BW and BW change over the trial and values of $\mathrm{N}$ and energy utilization in dairy goats fed the experimental diets.

\begin{tabular}{|c|c|c|c|c|}
\hline \multirow[t]{2}{*}{ Item } & \multicolumn{2}{|c|}{$\operatorname{Diet}^{1}$} & \multirow[t]{2}{*}{ SEM } & \multirow[t]{2}{*}{ P-value } \\
\hline & Control & BYP & & \\
\hline $\mathrm{BW}, \mathrm{kg}$ & 44.8 & 45.8 & 0.60 & 0.29 \\
\hline BW change, $\mathrm{kg}$ & -6.78 & -5.86 & 0.453 & 0.18 \\
\hline $\mathrm{BW}^{0,75}$ & 17.3 & 17.6 & 0.18 & 0.24 \\
\hline \multicolumn{5}{|l|}{$\mathrm{g} / \mathrm{kg}$ of $\mathrm{BW}^{0,75}$} \\
\hline $\mathrm{N}$ intake & 2.65 & 2.84 & 0.051 & 0.031 \\
\hline Fecal N & 0.655 & 0.724 & 0.0228 & 0.06 \\
\hline Urine $\mathrm{N}$ & 1.40 & 1.31 & 0.056 & 0.27 \\
\hline Milk total N & 0.569 & 0.615 & 0.0145 & 0.06 \\
\hline Milk protein $\mathrm{N}$ & 0.494 & 0.535 & 0.0129 & 0.06 \\
\hline Digestible $\mathrm{N}^{2}$ & 2.00 & 2.12 & 0.049 & 0.10 \\
\hline $\mathrm{N}$ retained body ${ }^{3}$ & 0.594 & 0.829 & 0.0811 & 0.071 \\
\hline Total $\mathrm{N}$ retained ${ }^{4}$ & 0.025 & 0.218 & 0.0788 & 0.12 \\
\hline \multicolumn{5}{|l|}{$\mathrm{N}$ utilization, $\mathrm{g} / \mathrm{g}$} \\
\hline Digestible N/intake N & 0.753 & 0.746 & 0.0066 & 0.48 \\
\hline $\mathrm{N}$ retained body/digestible $\mathrm{N}$ & 0.284 & 0.377 & 0.0360 & 0.10 \\
\hline Milk protein N/digestible $\mathrm{N}$ & 0.252 & 0.256 & 0.0076 & 0.74 \\
\hline Milk protein N/milk total $\mathrm{N}$ & 0.868 & 0.869 & 0.0035 & 0.82 \\
\hline Milk protein N/intake $\mathrm{N}$ & 0.189 & 0.190 & 0.0047 & 0.81 \\
\hline \multicolumn{5}{|l|}{$\mathrm{MJ} / \mathrm{kg}$ of $\mathrm{BW}^{0,75}$} \\
\hline Gross energy intake & 1.73 & 1.73 & 0.027 & 0.98 \\
\hline Fecal energy & 0.432 & 0.461 & 0.0130 & 0.15 \\
\hline Urine energy & 0.073 & 0.082 & 0.0036 & 0.11 \\
\hline Milk energy & 0.393 & 0.428 & 0.0102 & 0.042 \\
\hline Digestible energy intake ${ }^{5}$ & 1.30 & 1.27 & 0.024 & 0.51 \\
\hline ME intake ${ }^{6}$ & 1.14 & 1.12 & 0.024 & 0.45 \\
\hline \multicolumn{5}{|l|}{ Energy utilization, $\mathrm{MJ} / \mathrm{MJ}$} \\
\hline Digestible energy/energy intake & 0.751 & 0.735 & 0.0064 & 0.11 \\
\hline Milk energy/digestible energy & 0.307 & 0.338 & 0.0085 & 0.031 \\
\hline Milk energy/ME & 0.349 & 0.388 & 0.0104 & 0.030 \\
\hline ME/energy intake & 0.661 & 0.642 & 0.0070 & 0.09 \\
\hline ME/digestible energy & 0.881 & 0.874 & 0.0035 & 0.24 \\
\hline
\end{tabular}

${ }^{1}$ Control: 40:60 alfalfa hay:high-cereal concentrate; BYP: 40:60 alfalfa hay:concentrate containing by-products

${ }^{2}$ Digestible $\mathrm{N}=\mathrm{N}$ intake - fecal $\mathrm{N}$.

${ }^{3} \mathrm{~N}$ retained body $=\mathrm{N}$ intake - fecal $\mathrm{N}-$ urine $\mathrm{N}$.

${ }^{4}$ Total $\mathrm{N}$ retained $=\mathrm{N}$ intake - fecal $\mathrm{N}-$ urine $\mathrm{N}-$ milk total $\mathrm{N}$.

${ }^{5}$ Digestible energy $=$ energy intake - fecal energy.

${ }^{6} \mathrm{ME}=$ digestible energy - urine energy - methane energy; A value of $0.890 \mathrm{MJ} / \mathrm{mol}$ of methane (Newbold et al., 2007) was used for calculations. 
Table 32. Average values of milk yield and composition and feed efficiency in dairy goats fed the experimental diets.

\begin{tabular}{|c|c|c|c|c|}
\hline \multirow[t]{2}{*}{ Item } & \multicolumn{2}{|c|}{$\operatorname{Diet}^{1}$} & \multirow{2}{*}{ SEM } & \multirow{2}{*}{ P-value } \\
\hline & Control & BYP & & \\
\hline \multicolumn{5}{|l|}{ Milk yield, g/d } \\
\hline Milk & 1967 & 2123 & 49.5 & 0.06 \\
\hline Fat & 91.0 & 102 & 2.8 & 0.025 \\
\hline Protein & 62.6 & 68.9 & 1.71 & 0.031 \\
\hline Casein & 39.2 & 42.8 & 1.42 & 0.11 \\
\hline Whey protein & 22.9 & 25.5 & 0.51 & 0.007 \\
\hline Lactose & 102 & 109 & 3.4 & 0.17 \\
\hline $\mathrm{TS}$ & 269 & 298 & 7.6 & 0.028 \\
\hline Gross energy, $\mathrm{MJ} / \mathrm{d}$ & 6.77 & 7.50 & 0.202 & 0.033 \\
\hline \multicolumn{5}{|l|}{ Milk composition, $\mathrm{g} / \mathrm{kg}$} \\
\hline Fat & 45.8 & 47.8 & 1.00 & 0.20 \\
\hline Protein & 31.8 & 32.9 & 0.26 & 0.026 \\
\hline Casein & 20.0 & 20.5 & 0.31 & 0.38 \\
\hline Whey protein & 11.6 & 12.0 & 0.26 & 0.22 \\
\hline Lactose & 52.1 & 52.9 & 0.67 & 0.44 \\
\hline $\mathrm{TS}$ & 137 & 141 & 1.4 & 0.10 \\
\hline Gross energy, $\mathrm{MJ} / \mathrm{kg}$ & 3.44 & 3.53 & 0.054 & 0.25 \\
\hline Feed eficiency ${ }^{2}$ & 23.1 & 24.8 & 0.62 & 0.08 \\
\hline
\end{tabular}

${ }^{1}$ Control: 40:60 alfalfa hay:high-cereal concentrate; BYP: 40:60 alfalfa hay:concentrate containing by-products

${ }^{2}$ Efficiency of feed utilization; feed efficiency $=($ Milk energy/energy intake $) \times 100$.

The gross energy in milk observed for BYP-fed goats (Table 32) is consistent with the greater proportion of digestible ME used for milk production (Table 31), which would indicate a greater energy efficiency for milk production. In fact, feed efficiency tended $(\mathrm{P}=0.08)$ to be higher in goats fed the BYP diet. Overall, there was no difference in milk composition between the two diets, excepting the greater $(\mathrm{P}=0.026)$ protein content obtained with diet BYP compared with control diet (Table 32), which is consistent with the trend $(\mathrm{P}=0.10$; Table 31$)$ to greater digestible $\mathrm{N}$ in these goats.

The FA profile of goat milk is affected by the FA and chemical composition of the diet (Vasta et al., 2008). Total saturated FA (SFA) in milk from goats fed BYP diet were significantly lower $(\mathrm{P}=0.035)$ compared with control diet (Table 33), but there were differences in the response to diet among the individual SFA. Compared with milk 
from control goats, concentrations of $\mathrm{C} 14: 0$ were lower $(\mathrm{P}=0.008)$ and those of $\mathrm{C} 12: 0$ and $\mathrm{C} 16: 0$ tended to be lower ( $\mathrm{P}=0.08$ and 0.05 , respectively) in the milk from BYPfed goats, whereas goats fed BYP had greater $(\mathrm{P}=0.002)$ concentrations of stearic acid. These results indicate a potentially healthier profile of the milk from BYP-fed goats, as $\mathrm{C} 12: 0, \mathrm{C} 14: 0$ and $\mathrm{C} 16: 0$ are atherogenic and have been related to an increase in total and low density lipoprotein cholesterol concentrations (Williams, 2000), whereas C18:0 is considered to have no effect on colesterol values. There was no difference $(P \geq 0.63)$ between diets in any branched-chain FA (C15:0 iso, C17:0 iso and C18:0 anteiso). In agreement with our results, Cais-Sokolińska et al. (2019) observed an increase in stearic acid concentration in the milk of dairy goats when DGGS were included in the diet at a rate of $120 \mathrm{~g} / \mathrm{kg}$, but no information on shorter chain FA was reported in their study. Ibáñez et al. (2016) reported no effect of including $600 \mathrm{~g}$ of DCP per $\mathrm{kg}$ of diet in the concentration of $\mathrm{C} 4$ to $\mathrm{C} 15 \mathrm{FA}$ in goat milk.

Olive cake is characterized by a high monounsaturated FA (MUFA) content, especially of oleic acid (Chiofalo et al., 2004), and its inclusion in the diet of dairy ewes has been shown to reduce SFA and increase MUFA content in milk (Vargas-BelloPérez et al., 2013; Chiofalo et al., 2004). In our study, milk from BYP-fed goats tended $(\mathrm{P}=0.08)$ to have greater total MUFA content, but there were differences in the individual FA. Concentrations of 9-hexadecanoic acid (C16:1 trans-9) and elaidic acid (C18:1 trans-9) were greater $(\mathrm{P}=0.004$ and 0.036 , respectively) and those of oleic (C18:1 cis-9) and 11-octadecenoic acids $(\mathrm{C} 18: 1$ cis-11) tended to be greater $(\mathrm{P} \leq 0.086)$ in the milk from goats fed BYP diet compared with control diet, with no differences in the other MUFA analyzed. The intake of trans FA is considered a risk factor for coronary heart disease and diabetes in consumers (Salmeron et al., 2001), but oleic acid is considered a beneficial FA for human health (Dewhurst et al., 2006). The content of vaccenic acid (C18:1 trans-11) was similar for both diets, and values were greater than those reported for goat milk in previous studies $(0.95 \mathrm{~g} / 100 \mathrm{~g}$ of total FA identified; Romero-Huelva et al., 2017; Ibáñez et al., 2016; Molina-Alcaide et al., 2010). As discussed by Ibáñez et al. (2016), greater vaccenic acid contents seem to be positively correlated with negative energy balances in goats and cows. 
Table 33. Average values of fatty acids (FA) composition ( $\mathrm{g} / 100 \mathrm{~g}$ of identified FA) in milk fat from dairy goats fed the experimental diets.

\begin{tabular}{|c|c|c|c|c|}
\hline \multirow[t]{2}{*}{ Item } & \multicolumn{2}{|c|}{$\operatorname{Diet}^{1}$} & \multirow[t]{2}{*}{ SEM } & \multirow[t]{2}{*}{ P-value } \\
\hline & Control & BYP & & \\
\hline $\mathrm{C} 4: 0$ & 2.44 & 2.65 & 0.042 & 0.07 \\
\hline C6:0 & 2.97 & 3.09 & 0.058 & 0.36 \\
\hline $\mathrm{C} 8: 0$ & 3.53 & 3.60 & 0.080 & 0.70 \\
\hline C10:0 & 11.5 & 10.9 & 0.24 & 0.32 \\
\hline C12:0 & 4.76 & 3.98 & 0.167 & 0.08 \\
\hline $\mathrm{C} 14: 0$ & 9.95 & 8.34 & 0.164 & 0.008 \\
\hline $\mathrm{C} 15: 0$ iso & 0.131 & 0.127 & 0.0059 & 0.78 \\
\hline C16:0 & 28.7 & 26.8 & 0.36 & 0.05 \\
\hline $\mathrm{C} 17: 0$ iso & 0.374 & 0.359 & 0.0143 & 0.64 \\
\hline C18:0 & 7.76 & 9.05 & 0.084 & 0.002 \\
\hline C18:0 anteiso & 0.363 & 0.382 & 0.0185 & 0.63 \\
\hline C20:0 & 0.186 & 0.152 & 0.0260 & 0.56 \\
\hline Total saturated FA & 74.7 & 71.5 & 0.51 & 0.035 \\
\hline C14:1 cis -9 & 0.123 & 0.117 & 0.0086 & 0.76 \\
\hline $\mathrm{C} 16: 1$ cis-9 & 0.691 & 0.728 & 0.0098 & 0.13 \\
\hline C16:1 trans -9 & 0.092 & 0.165 & 0.0062 & 0.004 \\
\hline $\mathrm{C} 18: 1$ cis $-9^{2}$ & 18.3 & 20.4 & 0.46 & 0.09 \\
\hline C18:1 trans -9 & 0.322 & 0.369 & 0.0076 & 0.036 \\
\hline C18:1 cis-11 & 0.438 & 0.509 & 0.0158 & 0.09 \\
\hline C18:1 trans -11 & 1.333 & 1.311 & 0.1096 & 0.93 \\
\hline Total monounsaturated FA & 21.3 & 23.6 & 0.48 & 0.08 \\
\hline $\mathrm{C} 18: 2$ cis-9, cis-12 & 2.42 & 2.96 & 0.038 & 0.002 \\
\hline $\mathrm{C} 18: 2$ cis -9, trans -11 & 0.540 & 0.938 & 0.0260 & 0.002 \\
\hline $\mathrm{C} 18: 3$ cis -6, cis -9, cis -12 & 0.046 & 0.039 & 0.0021 & 0.17 \\
\hline $\mathrm{C} 18: 3$ cis -9, cis $-12, c i s-15$ & 0.326 & 0.318 & 0.0070 & 0.62 \\
\hline C20:5 cis-5, cis-8, cis-11, cis-14, cis-17 & 0.083 & 0.087 & 0.0055 & 0.76 \\
\hline C22:6 cis-4, cis-7, cis-10, cis-13, cis-16, cis-19 & 0.011 & 0.013 & 0.0007 & 0.24 \\
\hline Total polyunsaturated FA & 3.90 & 4.85 & 0.052 & 0.001 \\
\hline \multicolumn{5}{|l|}{ According to origin ${ }^{3}$} \\
\hline$<16$ carbon & 36.4 & 33.9 & 0.70 & 0.139 \\
\hline 16 carbon & 29.7 & 27.8 & 0.35 & 0.054 \\
\hline$>16$ carbon & 33.8 & 38.3 & 0.56 & 0.016 \\
\hline$\sum \mathrm{n}-3 / \sum \mathrm{n}-6$ & 0.148 & 0.111 & 0.0029 & 0.003 \\
\hline \multicolumn{5}{|c|}{$\begin{array}{l}{ }^{1} \text { Control: } 40: 60 \text { alfalfa hay:high-cereal concentrate; BYP: } 40: 60 \text { alfalfa hay:concentrate } \\
\text { containing by-products } \\
{ }^{2} \text { Contains } \mathrm{C} 18 \cdot 1 \text { trans- } 12 \text { and } \mathrm{C} 18 \cdot 1 \text { cis-10 as minor comnonents }\end{array}$} \\
\hline \multicolumn{5}{|c|}{$\begin{array}{l}3<16 \text {-carbon FA represent de novo synthesized FA, }>16 \text {-carbon FA represent } \\
\text { preformed FA taken up from circulation, and 16-carbon FA are derived from both } \\
\text { sources. }\end{array}$} \\
\hline
\end{tabular}


Finally, total polyunsaturated FA (PUFA) content in milk from BYP-fed goats was $24.4 \%$ greater $(P=0.001)$ compared with control diet, and more specifically concentrations of linoleic acid (C18:2 cis-9, cis-12) and rumenic (CLA; C18:2 cis-9, trans-11) acids were 22.3 and $73.7 \%$, respectively, greater in milk from goats fed BYP diet compared with that from goats fed control diet. No differences $(P \geq 0.167)$ between diets were observed in the rest of PUFA identified. The PUFA are considered healthy for humans, and a wide list of health benefits have been attributed to those FA, but especially to CLA (Parodi, 2009; Banni et al., 2003), as its intake has been negatively related to the risk of colorectal cancer (Larsson et al., 2005), being its anti-mutagenic properties attributed mainly to rumenic acid (Lock et al., 2004). The increase in PUFA concentrations observed in milk from BYP-fed goats is in agreement with previous studies reporting increases in PUFA, and especially rumenic and linoleic acids, when DDGS (Cais-Sokolińska et al., 2019, 2015) and DCP (Ibáñez et al., 2016) replaced high-starch sources in the diet of dairy goats. Differences in milk FA profile can be due to differences in FA intake, but also to other factors as the intake of energy (Leiber et al., 2005) or plant secondary compounds that can influence the biohydrogenation of unsaturated FA in the rumen (Vasta et al., 2008). Altogether, these results indicate that BYP feeding changed milk fat quality.

No differences between diets were observed in milk content of $<16 \mathrm{C} \mathrm{FA}$, but C16 FA tended $(\mathrm{P}=0.05)$ to be greater in milk from control-fed goats. The concentration of $>16 \mathrm{C}$ FA was $14.8 \%$ greater $(\mathrm{P}=0.016)$ in the milk from goats fed BYP diet compared with control diet, which would indicate that a greater proportion of FA were taken up directly by the mammary gland, and therefore a greater amount of PUFA reaching the small intestine without being biohydrogenated in the rumen. Finally, feeding BYP decreased $(\mathrm{P}=0.003)$ by $25 \%$ the $\Sigma \mathrm{n} 3-$ to- $\Sigma \mathrm{n} 6$ ratio in milk compared with control diet. In agreement with our results Cais-Sokolińska et al. (2019) observed a reduction in the $\Sigma \mathrm{n} 3$-to- $\Sigma \mathrm{n} 6$ ratio (from 0.171 to 0.091 ) in the milk of dairy goats by including $120 \mathrm{~g}$ of DDGS per $\mathrm{kg}$ of diet, Increasing this ratio in the diet has been considered favorable for human health (Simopoulos, 2002), although some limitations when considering the ratio between these two families of PUFA have also been risen (Marventano et al., 2015). 
IX.2.3.4. Ruminal fermentation, methane emissions, and purine derivatives excretion

There was no effect of diet $(\mathrm{P} \geq 0.33)$ on $\mathrm{pH}$, total VFA and $\mathrm{NH}_{3}$ concentrations and VFA profile (Table 34). Low VFA concentrations and greater $\mathrm{pH}$ values are often obtained when rumen content is collected through stomach tubing instead of a rumen cannula (Ramos-Morales et al., 2014). The values observed in our study were similar to those obtained in other studies in Murciano-Granadina goats receiving similar diets and using the same sampling procedure (Romero-Huelva et al., 2017; 2012). Protein of DDGS has been reported to have a lower degradability than other protein sources commonly used in ruminants feeding (Beenchar et al., 2013; NRC, 2001), but $\mathrm{NH}_{3}-\mathrm{N}$ concentrations in the rumen were adequate for microbial growth with both diets (Firkins et al., 2007).

As shown in Table 34, there were no differences $(\mathrm{P} \geq 0.655)$ between diets in methane emissions, indicating the lack of antimethanogenic compounds in the BYP diet. In agreement with our results, López et al. (2014) and Ibáñez et al. (2016) reported no effect of DCP on methane production by dairy goats. In contrast, Benchaar et al. (2013) observed a reduction in methane emissions when DDGS were fed to dairy cows, and Pecka-Kielb et al. (2017) observed the same effect in sheep. Benchaar et al. (2013) attributed this antimethanogenic effect to a decrease in the fibre degradation in the rumen caused by the high EE content of DDGS, but in our study the EE content of BYP concentrate $(47.0 \mathrm{~g} / \mathrm{kg}$; Table 29$)$ was below the fat level recommended in the diet of ruminants to avoid reductions in fiber degradability (NRC, 2001). The lack of differences between diets in both NDF digestibility (Table 30) and VFA profile (Table 34) supports the absence of any antimethanogenic compound in BYP diet. In contrast, several studies (Romero-Huelva et al., 2017, 2012) have reported a decrease in methane emissions when other by-products, such as tomato wastes, were included in the diet. 
Table 34. Average values of ruminal fermentation parameters, methane emissions, daily urinary excretion of creatinine and purine derivatives and estimated microbial $\mathrm{N}$ flow in dairy goats fed the experimental diets.

\begin{tabular}{|c|c|c|c|c|}
\hline \multirow{2}{*}{ Item } & \multicolumn{2}{|c|}{ Diet $^{1}$} & \multirow{2}{*}{ SEM } & \multirow{2}{*}{ P-value } \\
\hline & Control & BYP & & \\
\hline \multicolumn{5}{|c|}{ Ruminal fermentation parameters } \\
\hline $\mathrm{pH}$ & 6.94 & 6.93 & 0.063 & 0.90 \\
\hline Total VFA, $\mathrm{m} M$ & 70.1 & 74.1 & 13.67 & 0.84 \\
\hline \multicolumn{5}{|c|}{ Molar proportions, $\mathrm{mmol} / 100 \mathrm{~mol}$} \\
\hline Acetate & 65.6 & 66.6 & 1.34 & 0.62 \\
\hline Propionate & 11.2 & 12.9 & 1.21 & 0.35 \\
\hline Butyrate & 14.6 & 12.5 & 1.45 & 0.33 \\
\hline Minor $\mathrm{VFA}^{2}$ & 8.54 & 7.97 & 1.184 & 0.74 \\
\hline Acetate/Propionate & 6.07 & 5.52 & 0.644 & 0.56 \\
\hline $\mathrm{NH}_{3}, \mathrm{mg} / 100 \mathrm{ml}$ & 12.6 & 11.0 & 1.47 & 0.45 \\
\hline \multicolumn{5}{|l|}{ Methane emissions } \\
\hline $\mathrm{CH}_{4}, \mathrm{~L} / \mathrm{d}$ & 36.7 & 34.4 & 3.52 & 0.66 \\
\hline $\mathrm{CH}_{4}, \mathrm{~L} / \mathrm{kg}$ of $\mathrm{DMI}$ & 21.7 & 20.7 & 1.89 & 0.71 \\
\hline $\mathrm{CH}_{4}, \mathrm{~L} / \mathrm{kg}$ of $\mathrm{BW}^{0.75}$ & 2.21 & 2.06 & 0.220 & 0.66 \\
\hline Urinary excretion, $\mathrm{mmol} / \mathrm{d}$ & 5.69 & 3.50 & 0.400 & 0.003 \\
\hline Allantoin & 9.04 & 7.19 & 0.576 & 0.05 \\
\hline Hypoxanthine & 0.298 & 0.367 & 0.0697 & 0.50 \\
\hline Xanthine & 0.112 & 0.117 & 0.0124 & 0.80 \\
\hline Uric acid & 2.65 & 2.23 & 0.175 & 0.11 \\
\hline Total purine derivatives ${ }^{3}$ & 12.1 & 9.90 & 0.770 & 0.07 \\
\hline
\end{tabular}

${ }^{1}$ Control: 40:60 alfalfa hay:high-cereal concentrate; BYP: 40:60 alfalfa hay:concentrate containing by-products

${ }^{2}$ Calculated as the sum of isobutyrate, isovalerate and valerate

${ }^{3}$ Calculated as the sum of allantoin, hypoxanthine, xanthine and uric acid

The greater $(\mathrm{P}=0.003)$ values of urinary excretion of creatinine observed in the control goats than in those BYP-fed are in agreement with the numerically greater body weight loss of these goats (Table 31), as creatinine is a metabolic product of creatine and phosphocreatine, both being found almost exclusively in muscle (Van Niekerk et al., 1963). Feeding BYP diet decreased the urinary excretion of allantoin $(\mathrm{P}=0.046)$ 
and tended to decrease $(\mathrm{P}=0.07)$ the excretion of total purine derivatives, which would indicate a lower microbial protein synthesis in BYP-fed goats, as urinary excretion of purine derivatives is used as an index of ruminal microbial protein synthesis (Balcells et al., 1991). The low ruminal degradability of DDGS protein might have caused a deficit of RDP in BYP concentrate, but $\mathrm{NH}_{3}-\mathrm{N}$ and minor VFA concentrations measured in the rumen do not support this hypothesis, as both values were adequate for optimal microbial growth (Zhang et al., 2013; Firkins et al., 2007). For both diets, ratios of creatinine/allantoin and creatinine/total purine derivatives were in the range of values previously reported for goats (Romero-Huelva et al., 2017).

\section{IX.2.4. Conclusions}

A mixture of corn DDGS, DCP and EOC could replace $44 \%$ of cereal grains and protein feeds in the concentrate for dairy goats without compromising nutrient utilization or ruminal fermentation, and resulted in greater milk fat and protein production as well as a more unsaturated milk FA profile. The use of these by-products did not affect methane emissions, but can reduce the negative environmental impact associated with their disposal. Our results indicate that the CP content in the diets used in our study was in excess of goats requirements.

Funding and Acknowledgments: Funding provided by the MINECO (Project AGL2016-75322-C2-1-R) and the Excellence Programme of Junta de Andalucía (Project P12-AGR-587) is gratefully acknowledged. Thanks are given to SACYR Industrial for providing free the exhausted olive cake used in this study.

\section{References}

Abecia, L., Toral, P. G., Martin-García, A.I., Martínez, G., Tomkins, N. W., MolinaAlcaide, E., Newbold, C. J., and Yánez-Ruíz, D. R. (2012). Effect of bromochloromethane on methane emission, rumen fermentation pattern, milk yield, and fatty acid profile in lactating dairy goats. Journal of Dairy Science 95, 2027-2036.

Aguilera, J. F., Prieto, C., and Fonollá, J. (1990). Protein and energy metabolism of lactating Granadina goats. British Journal of Nutrition 63, 165-75.

Anderson, J. L., Schingoethe, D. J., Kalscheur, K. F., and Hippen, A. R. (2006). Evaluation of dried and wet distillers grains included at two concentrations in the diets of lactating dairy cows. Journal of Dairy Science 89, 3133-3142. 
Association of Official Analytical Chemists (AOAC). (2005). Official Methods of Analysis, 18th ed. AOAC International.

Bakshi, M. P. S., Wadhwa, M., and Makkar, H. (2016). Waste to worth: vegetable wastes as animal feed. CAB Reviews 11, 1-26.

Balcells, J., Guada, J. A., Castrillo, C., and Gasa, J. (1991). Urinary excretion of allantoin and allantoin precursors by sheep after different rates of purine infusion into the duodenum. The Journal of Agricultural Science Cambridge 116, 309-317.

Balcells, J., Guada, J., Peiró, J., and Parker, D. (1992). Simultaneous determination of allantoin and oxypurines in biological fluids by high-performance liquid chromatography. Journal of Chromatography B 575, 153-157.

Bampidis, V. A., and Robinson, P. H. (2006). Citrus by-products as ruminant feeds: A review. Animal Feed Science and Technology 128, 175-217.

Banni, S., Heys, S. D., and Wahle, K. W. J. Conjugated linoleic acids as anticancer nutrients: studies in vivo and cellular mechanisms. Illinois, USA, ed. Sébédio, W., Christie, W., Adolf, R. O. 2003. In "Advances in Conjugated Linoleic Acid Research, vol. 2". pp. 267-282. American Oil Chemists Society Press.

Benchaar, C., Hassanat, F., Gervais, R., Chouinard, P. Y., Julien, C., Petit, V., and Massé, D. I. (2013). Effects of increasing amounts of corn dried distillers grains with solubles in dairy cow diets on methane production, ruminal fermentation, digestion, $\mathrm{N}$ balance, and milk production. Journal of Dairy Science 96, 1-15.

Cais-Sokolińska, D., Wójtowski, J., Pikul, J., Danków, R., Majcher, M., Teichert, J., and Bagnicka, E. (2019). The effect of unsaturated fatty acid concentration on the aroma profile of goat's milk. Annals of Animal Science 19, 483-498.

Cais-Sokolińska, D., Wójtowski, J., Pikul, J., Danków, R., Majcher, M., Teichert, J., and Bagnicka, E. (2015). Formation of volatile compounds in kefir made of goat and sheep milk with high polyunsaturated fatty acid content. Journal of Dairy Science $\mathbf{9 8 ,}$ $6692-6705$.

Chiofalo, B., Liotta, L., Zumbo, A., and Chiofalo, V. (2004). Administration of olive cake for ewe feeding: Effect on milk yield and composition. Small Ruminant Research 55, 169-176.

Del Prado A., Mas, K., Pardo, G., and Gallejones P. (2013). Modelling the interactions between $\mathrm{C}$ and $\mathrm{N}$ farm balances and GHG emissions from confinement dairy farms in 
northern Spain. Science of the Total Environment 465, 156-165.

Dewhurst, R. J., Shingfield, K. J., Lee, M. R. F., and Scollan, N. D. (2006). Increasing the concentrations of beneficial polyunsaturated fatty acids in milk produced by dairy cows in high-forage systems. Animal Feed Science and Technology 131, 168-206.

Hollmann, M., Allen, M. S., and Beede, D. K. (2011). Diet fermentability influences lactational performance responses to corn distillers grains: A meta-analysis. Journal of Dairy Science 94, 2007-2021.

Firkins, J. L., Yu, A., and Morrison, M. (2007). Ruminal nitrogen metabolism: perspectives for integration of microbiology and nutrition for dairy cows. Journal of Dairy Science 90 Suppl 1, 1-16.

Folch, J., Lees, M., and Stanley, G. H. S. (1957). A simple method for the isolation and purification of total lipides from animal tissues. Journal of Biological Chemistry 226, 497-509.

Ibáñez, C., Criscioni, P., Arriaga, H., Merino, P., Espinós, F. J., and Fernández, C. (2016). Murciano-Granadina Goat Performance and Methane Emission after Replacing Barley Grain with Fibrous By-Products. PLoS One 11(3), e0151215.

Janicek, B. N., Kononoff, P. J., Gehman, A. M., and Doane, P. H. (2008). The effect of feeding dried distillers grains plus solubles on milk production and excretion of urinary purine derivatives. Journal of Dairy Science 91, 3544-3553.

Kleinschmit, D. H., Schingoethe, D. J., Kalscheur, K. F., and Hippen, A. R. (2006). Evaluation of various sources of corn dried distillers grains plus solubles for lactating dairy cattle. Journal of Dairy Science 89, 4784-4794.

Kramer, J. K. G., and Zhou, J. (2001). Conjugated linoleic acid and octadecenoic acids: Extraction and isolation of lipids. European Journal of Lipid Science and Technology 103, 594-600.

Kurokawa, Y., Shibata, H., Tateno, S., Kanda, S., Takaura, K., Ishida, S., and Itabashi, H. (2012). Rumen fermentation, milk production and conjugated linoleic acid in the milk of cows fed high fiber diets added with dried distillers grains with solubles. Animal Science Journal 84, 106-112.

Larsson, S. C., Bergkvist, L., and Wolk, A. (2005). High-fat dairy food and conjugated linoleic acid intakes in relation to colorectal cancer incidence in the Swedish Mammography cohort. The American Journal of Clinical Nutrition 82, 894-900. 
Leiber, F., Kreuzer, M., Nigg, D., Wettstein, H. R., and Leo-Scheeder, M. R. (2005). A study on the causes for the elevated n- 3 fatty acids in cows' milk of alpine origin. Lipids 40, 191-202.

Lock, A. L., Corl, B. A., Bauman, D. E., and Ip, C. (2004). The anticarcinogenic effects of trans-11 18:1 is dependent on its conversion to cis-9, trans-11 conjugated linoleic acid via $4-9$ desaturase. Journal of Nutrition 134, 2698-2704.

López, M. C., Estellés, F., Moya, V. J., and Fernández, C. (2014). Use of dry citrus pulp or soybean hulls as a replacement for corn grain in energy and nitrogen partitioning, methane emissions, and milk performance in lactating Murciano-Granadina goats. Journal of Dairy Science 97, 7821-7832.

Luciano, G., Pauselli, M., Servili, M., Mourvaki, E., Serra, A., Monahan, F. J., Lanza, M., Priolo, A., Zinnai, A., and Mele, M. (2013). Dietary olive cake reduces the oxidation of lipids, including cholesterol, in lamb meat enriched in polyunsaturated fatty acids. Meat Science 93, 703-714.

Marcos, C. N., García-Rebollar, P., de Blas, C., and Carro, M. D. (2019). Variability in the Chemical Composition and In Vitro Ruminal Fermentation of Olive Cake ByProducts. Animals 9, 109.

Molina-Alcaide, E., and Yáñez-Ruiz, D. R. (2008). Potential use of olive by-products in ruminant feeding: A review. Animal Feed Science and Technology 147, 247-264.

Molina-Alcaide, E., Morales-Garcia, E. Y., Martin-Garcia, A. I., Ben Salem, H., Nefzaoui, A., and Sanz-Sampelayo, M. R. (2010). Effects of partial replacement of concentrate with feed blocks on nutrient utilization, microbial $\mathrm{N}$ flow, and milk yield and composition in goats. Journal of Dairy Science 93, 2076-2087.

Newbold, C. J., López, S., Nelson, N., Ouda, J. O., Wallace, R. J., and Moss, A. R. (2007). Propionate precursors and other metabolic intermediates as possible alternative electron acceptors to methanogenesis in ruminal fermentation in vitro. British Journal of Nutrition 94, 27-35.

NRC (National Research Council). (2001). Nutrient Requirements of Dairy Cattle, 7th ed. National Academy of Sciences.

Parodi, P. W. (2009). Has the association between saturated fatty acids, serum cholesterol and coronary heart disease been over emphasized?. Review International Dairy Journal 19, 345-361. 
Pearson, D. (1976). The Chemical Analysis of Foods. London, UK.

Pecka-Kielb, E., Zachwieja, A., Miśta, D., Zawadzki, W., and Zielak-Steciwko, A. Use of Corn Dried Distillers Grains (DDGS) in Feeding of Ruminants. 2017. In "Frontiers in Bioenergy and Biofuels". pp. 495-511.

Prieto, C., Aguilera, J. F., Lara, L., and Fonollá, J. (1990). Protein and energy requirements for maintenance of indigenous Granadina goats. British Journal of Nutrition 63, 155-163.

Radunz, A. E., Fluharty, F. L., Zerby, H. N., and Loerch, S. C. (2011). Winter-feeding systems for gestating sheep I. Effects on pre- and postpartum ewe performance and lamb progeny preweaning performance. Journal of Animal Science 89, 467-477.

Ramos-Morales, E., Arco-Pérez, A., Martin-Garcia, A. I., Yáñez-Ruiz, D. R., Frutos, P., and Hervás, G. (2014). Use of stomach tubing as an alternative to rumen cannulation to study ruminal fermentation and microbiota in sheep and goats. Animal Feed Science and Technology 198, 57-66.

Recio, I., Pérez-Rodríguez, M. L., Amigo, L., and Ramos, M. (1997). Study of the polymorphism of caprine milk caseins by capillary electrophoresis. Journal of Dairy Research 64, 515-523.

Robertson, J. B., and Van Soest, P. J. The detergent system of analysis and its application to human foods. New York, USA, ed. James, W. P. T., Theander, O. 1981. In "The Analysis of Dietary Fiber in Food". pp. 123-142. Marcel Dekker.

Romero-Huelva, M., Ramos-Morales, E., and Molina-Alcaide, E. (2012). Nutrient utilization, ruminal fermentation, microbial abundances, and milk yield composition in dairy goats fed diets including tomato and cucumber waste fruits. Journal of Dairy Science 95, 6015-6026.

Romero-Huelva, M., and Molina-Alcaide, E. (2013). Nutrient utilization, ruminal fermentation, microbial nitrogen flow, microbial abundances, and methane emissions in goats fed diets including tomato and cucumber waste fruits. Journal of Animal Science 91, 914-923.

Romero-Huelva, M., Ramírez-Fenosa, M. A., Planelles-González, R., García-Casado, P., and Molina-Alcaide, E. (2017). Can by-products replace conventional ingredients in concentrate of dairy goat diet?. Journal of Dairy Science 100, 4500-4512.

Salmeron, J., Hu, F. B., and Manson, J. E. (2001). Dietary fat intake and risk of type 2 
diabetes in women. The American Journal of Clinical Nutrition 73, 1019-1026.

Simopoulos, A. P. (2002). The importance of the ratio of omega-6/omega-3 essential fatty acids. Biomedicine \& Pharmacotherapy 56, 365-379.

Singleton, V. L., and Rossi, J. A. (1965). Colorimetry of total phenolics with phosphomolybdic-phosphotungstic acids reagents. American Journal of Enology and Viticulture 16, 144-158.

Shingfield, K. J., Ahvenjärvi, S., Toivonen, V., Ärölä, A., Nurmela, K. V. V. P., Huhtanen, P., and Griinari, J. M. (2003). Effect of fish oil on biohydrogenation of fatty acids and milk fatty acid content in cows. Animal Science 77, 165-179.

Van Niekerk, B. D. H., Reid, J. T., Bensadoun, A., and Paladines, O. L. (1963). Urinary creatinine as an index of body composition. Journal of Nutrition 79, 463-473.

Van Soest, P. J., Robertson, J. B., and Lewis, B. A. (1991). Methods for dietary fiber, neutral detergent fiber and nonstarch polysaccharides in relation to animal nutrition. Journal of Dairy Science 74, 3583-3597.

Vargas-Bello-Perez, E., Vera, R. R., Aguilar, C., Lira, R., Pena, I., and Fernandez, J. (2013). Feeding olive cake to ewes improves fatty acid profile of milk and cheese. Animal Feed Science and Technology 184, 94-99.

Vasta, V., Nudda, A., Cannas, A., Lanza, M., and Priolo, A. (2008). Alternative feed resources and their effects on the quality of meat and milk from small ruminants. Animal Feed Science and Technology 147, 223-246..

Wilkinson, J. M. (2011). Re-defining efficiency of feed use by livestock. Animal 5, 1014-1022.

Williams, C. M. (2000). Dietary fatty acids and human health. Annales De Zootechnie 49, $165-180$.

Zhang, H. H., Chen, Y., Xu, X. L., and Yang, Y. X. (2013). Effects of Branched-chain Amino Acids on In vitro Ruminal Fermentation of Wheat Straw. Asian-Australasian Journal of Animal Science 26, 523-528. 
$\sim 220 \sim$ 


\section{IX.3. Python Script}

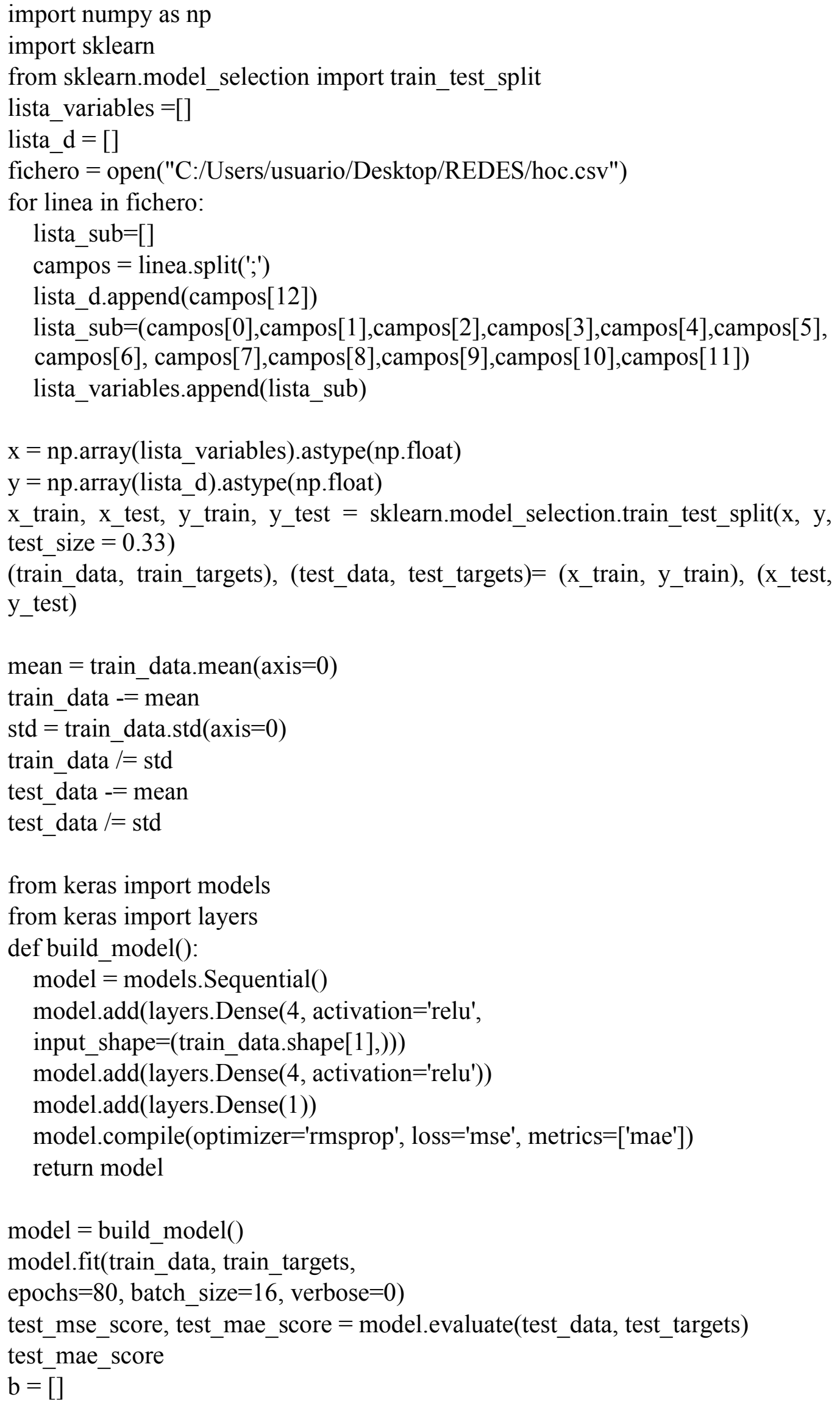


fichero = open("C:/Users/usuario/Desktop/REDES/comph.csv")

for linea in fichero:

lista_sub=[]

campos = linea.split(';')

lista_sub=(campos[0],campos[1],campos[2],campos[3],campos[4],campos[5],

campos[6], campos[7],campos[8],campos[9],campos[10],campos[11])

b.append(lista_sub)

$\mathrm{x}=\mathrm{np}$.array(b).astype(np.float)

$\mathrm{y}=\operatorname{model} . \operatorname{predict}(\mathrm{x})$

$\operatorname{print}(\mathrm{y})$ 
